Departamento de economía y ciencias sociales agrarias

Escuela Técnica Superior de Ingeniería Agronómica, Alimentaria y de Biosistemas

Universidad Politécnica de Madrid

\title{
Influence of external drivers on water use efficiency and sustainability in agricultural production
}

\author{
TESIS DOCTORAL \\ Daniel Chico Zamanillo Ingeniero Agrónomo \\ DIRECTORES \\ Alberto Garrido Colmenero Dr. Ingeniero Agrónomo \\ Universidad Politécnica de Madrid \\ Markus Pahlow \\ Dr. Johns Hopkins University
}

Madrid, 2017 



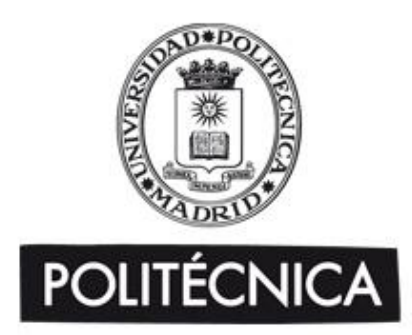

“Ingeniamos el futuro"

Tribunal nombrado por el Sr. Rector Magfco. de la Universidad Politécnica de Madrid, el día de de $201 \ldots$

Presidente:

Vocal:

Vocal:

Vocal:

Secretario:

Suplente:

Suplente:

Realizado el acto de defensa y lectura de la Tesis el dia ..... de de $201 \ldots . .$.

en la E.T.S.I./Facultad

Calificación

EL PRESIDENTE

LOS VOCALES

EL SECRETARIO 


\section{AGRADECIMIENTOS}

Esta tesis es el resultado de un proceso largo en el que me he apoyado en una larga lista de personas e instituciones a las que les debo mi agradecimiento. No hubiera llegado sin ellas.

En primer lugar, mi tutor, el catedrático Alberto Garrido. Desde el inicio hasta el final confió en mí y me apoyó. Siempre estuvo disponible, incluso cuando no tenía tiempo. Con él he aprendido desde los fundamentos de la investigación y me he desarrollado como profesional. Y sigo aprendiendo. Gracias.

To my co-supervisor, Dr. Markus Pahlow whom so kindly accepted the supervision and eagerly guided me in this effort, even from the other corner of the world. His excellent research skills and humor have been basic for this work.

A la Fundación Botín por financiar y apoyar el observatorio del agua y esta investigación. Al equipo del observatorio del agua, en especial a su director honorífico Ramón Llamas de quien tanto he aprendido y que siempre tanto nos ha animado a ser críticos, curiosos y a no tener pelos en la lengua. También por haber impulsado junto con Alberto y todo el equipo esa pequeña joya que es el Observatorio del agua. Ha sido una experiencia verdaderamente enriquecedora el formar parte de este equipo. A todo el equipo del observatorio, Bárbara Willaarts, Maite Aldaya, Lucia De Stefano, Elena López-Gunn, Pedro Martínez-Santos y a todos los “juniors”, Aurelién, Marta, Insa, Gloria y Bea.

En el CEIGRAM transcurrió buena parte de esta investigación y le debo una parte importante de esta tesis. Fue un lugar inmejorable donde formarme como investigador. Gracias al apoyo de todo el equipo de profesores y personal técnico, Esperanza, Katerina y Bego, siempre con los brazos abiertos para recibir a hijos pródigos. En el CEIGRAM compartí horas de trabajo y de no trabajo con compañeros de los que se lleva uno consigo; Jorge, Gloria, Elena, Lola, Teresa, Bárbara W., Bárbara S., Berta, Axel, Marina, Insa, Ana, Paula, Vanessa... y faltan más nombres que no me entran en esta página.

Debo agradecer a la Universidad de Sao Paulo y la Universidad Politécnica de Madrid la oportunidad de realizar dos estancias de investigación en el grupo GovAmb de la USP. Gracias a su financiación tuve la suerte de participar de un equipo interdisciplinar y conocer a investigadores excelentes que dieron la oportunidad a un ingeniero de acercarse a las ciencias humanas y entender que las respuestas no serán un número, sino una conversación. Gracias al prof. Jacobi y al prof. Sinisgalli por acogerme en sendas estancias de investigación. Natalia, Claudio, Marcelo, Alexandre Igari, Ana Paula Fracalanza, Gerardo y todo el equipo del GovAmb. 
Debo un agradecimiento especial también al investigador de Embrapa A. Santiago. Me abrió las puertas, literalmente, de su tierra y su casa y me sacó de mi eurocentrismo.

La parte final de esta tesis transcurrió en Holanda, como parte de la Water Footprint Network. Debo agradecer a la organización el apoyo prestado a la hora de combinar dos trabajos, y de orientar y estimular mi desarrollo profesional, Ruth Mathews, Guoping Zhang, Ashok Chapagain, Ertug Ercin, Alexandra Freitas, Xander de Bruine Chris Briggs y Sameer Safaya. Y a Elisabeth por la cuidadosa revisión del lenguaje y el suministro de galletas. Un grupo de profesionales, pero principalmente de personas

En la universidad de Twente he tenido oportunidad de coincidir con investigadores con los que he continuado aprendiendo en lo profesional y personal, A. Hoekstra, Abebe, Hatem, Joep S., La, Wenlong, Joep, Geert y la inevitable latinada, Juancho, Mireia, Angels, Filipe, Leo, Loreto, Ana Paula, Marcela. A la otra latinada, que me dio el último empujón; Luiza, Igor, Alex, Raúl, Iza, Romina y Lucas.

Hay otra serie de personas que, a pesar de no ser investigadores, han contribuido a esta tesis, aunque sea a base de terrazas y lavia; Sergio, Elena, Victor, María, Esther, Ximena, Elisa, Juandi, Raúl, María, Sara... y los zánganos, Antonio, Victor, Pablo, Carol Alba y Raquel.

Pero sobretodo quiero agradecer a mi familia, esas personas que estuvieron todo el tiempo a mi lado. A mis padres, que aunque no entiendan muy bien en lo que trabajo se aseguraron de que siempre hubiera un coche esperando en el aeropuerto y un plato delicioso al llegar a casa. Y también a la otra parte de mi familia, a los que todavía les es más difícil entender lo que escribo pero también había un plato de arroz con feijão al llegar.

A mi compañera. En los agradecimientos siempre se dice que sin su compañera/o no habría logrado terminar esta tesis... en otros casos no lo sé pero esta tesis existe gracias (y a pesar de) ella.

A todos ellos, gracias. 


\section{RESUMEN}

En un mundo en el que los recursos hídricos y la tierra cultivable son limitados, la agricultura es el principal usuario de ambos recursos, enfrentándose al reto de satisfacer unas necesidades crecientes de alimentos y productos de origen agrícola. Al mismo tiempo, la agricultura es una actividad multifuncional que regula varios procesos naturales y que resulta esencial para la seguridad alimentaria, el desarrollo humano y la economía de los medios rurales. Por tanto, se hace necesario un uso más eficiente del agua por parte del sector agrícola que al mismo tiempo no limite la provisión de bienes ambientales. Por otro lado, en una economía globalizada, la demanda por parte de los consumidores y las fuerzas económicas pueden determinar el desarrollo agrícola y por tanto, el uso de agua en la agricultura. Los consumidores y las empresas, de forma creciente, pueden ser actores relevantes en la gestión del agua a través de sus decisiones de compra y la creación de incentivos. Sin embargo, estos actores necesitan de indicadores y marcos de análisis que les permitan participar en esa gestión con información adecuada, de forma que puedan contribuir a la gestión sostenible y eficiente del agua. Este cambio hacia un uso más eficiente del agua en la agricultura se verá reforzado si se amplían las perspectivas, incluyendo además de los beneficios económicos asociados al uso de agua, la consideración de las externalidades ambientales y sociales. De este modo se podrá abordar la cuestión de cómo definir un uso eficiente del agua social y ambientalmente sostenible. Esta complejidad necesita también ser entendida y abordada por los diferentes grupos de interés.

El objetivo de esta tesis es la evaluación de la influencia de algunos vectores que condicionan las prácticas agrícolas y en consecuencia su uso del agua, su eficiencia y sostenibilidad. Asimismo, se explora la relación entre la perspectiva del producto, como unidad empleada en el sistema económico, y la cuenca hidrográfica, unidad del sistema socioambiental. La tesis emplea como herramienta el marco de análisis de la evaluación huella hídrica. La huella hídrica es un indicador holístico de uso de agua que considera el consumo de agua verde y azul y la presión sobre la calidad del agua. A lo largo de la tesis, el indicador se ve adaptado para ampliar la comprensión de algunas de las implicaciones del uso de agua en agricultura.

La tesis analiza la eficiencia del uso del agua en tres casos de estudio. El primer caso se centra en la producción de bioetanol en el nordeste brasileño en condiciones de secano y bajo 8 niveles crecientes de riego. Se considera la eficiencia de uso del agua en términos físicos y económicos a nivel de parcela. El segundo caso de estudio analiza la sostenibilidad de un 
producto de consumo, unos pantalones vaqueros, desde la perspectiva de una empresa textil. Para ello, el análisis se centra en la producción agraria y la contextualiza a nivel de parcela y de cuenca hidrográfica, analizando la influencia de la política agraria común en las prácticas agrícolas. El tercer caso de estudio evalúa las implicaciones del cambio de prácticas agrarias en la producción de caña de azúcar en una cuenca hidrográfica brasileña y de nuevo contextualiza los resultados a nivel de cuenca, en este caso, mediante el análisis comparativo con el resto de usos de suelo de la cuenca. Se realiza una valoración de dos servicios ecosistémicos (SE) como método para considerar las externalidades de la agricultura.

Los resultados del primer caso muestran cómo en la producción de etanol, la fase agrícola es el componente principal de la huella hídrica del producto, pues la fase industrial apenas representa el $1 \%$ de la huella hídrica total. Asimismo, el uso del bagazo y las vinazas, subproductos de la producción de etanol, reduce la huella hídrica total del etanol. Por otro lado, a medida que la lámina de riego aumenta, también aumentan el beneficio económico para el agricultor y la productividad física y económica del agua debido al aumento en los rendimientos de la caña de azúcar. Sin embargo, esta mejora se produce a costa de un aumento en la proporción de la huella hídrica total por litro de etanol de sus componentes azul y gris. La producción en secano muestra los menores resultados de huella hídrica total (verde, azul y gris), $1.64711^{-1}$, frente a la producción con mayor volumen de riego, en la que la huella hídrica en su fracción consuntiva es menor, $1.22511^{-1}$, pero la huella hídrica total es mayor, $1.75811^{-1}$, debido a la fracción de huella hídrica gris. Los resultados sugieren que la tendencia a irrigar con volúmenes cada vez mayores da lugar a una mayor eficiencia en el uso de agua a nivel de parcela. Sin embargo, esta conclusión no proporciona ninguna información sobre las consecuencias de las mayores presiones que se imponen en el sistema hidrológico por la mayor demanda de agua azul y potencial contaminación.

En el segundo caso de estudio, se estimó que el principal determinante de la huella hídrica en productos textiles es la fase de obtención de las fibras, y en particular de las fibras de algodón sobre otras fibras de origen celulósico $5.128 \mathrm{~m}^{3} \mathrm{t}^{-1} \mathrm{y} 2.285 \mathrm{~m}^{3} \mathrm{t}^{-1}$ respectivamente. El análisis de la producción de algodón colocó el foco en la influencia de la política agraria común como determinante de la rentabilidad del cultivo y por tanto de las prácticas agrícolas empleadas. La huella hídrica del algodón aumentó de media un 50\% como consecuencia de la desaparición de incentivos a la producción y por tanto de una menor aplicación de riego, fertilizantes y herbicidas. Sin embargo, al poner los resultados en el contexto de la cuenca, se mostró como 
la sostenibilidad del uso del agua está determinada en mayor medida por la gestión hidrológica y de los embalses.

El tercer caso de estudio se centró en la producción de caña de azúcar en secano en la cuenca hidrográfica del Mogi-Guaçu-Pardo en Sao Paulo, Brasil en el periodo 2000-2012. Se estudió la influencia de dos procesos, por un lado, la mecanización de la cosecha de la caña en respuesta a la implantación de un protocolo ambiental, y por otro el efecto de los cambios de uso de suelo en la cuenca. En este periodo, se produjo un crecimiento de la superficie de caña en la cuenca, principalmente a costa de superficie de cultivos anuales y de pastos. Se estimaron las implicaciones de estos cambios sobre la eficiencia económica de uso del agua en la caña y la evaluación de dos externalidades ambientales, provisión de agua y costes de erosión. Para abordar la incertidumbre en la estimación de algunas variables clave como las tasas de erosión de cada uso de suelo o la evapotranspiración de la vegetación natural, plantaciones de eucaliptos y de pastos, se aplicó una simulación Monte-Carlo de forma que los resultados se obtuvieron en términos probabilísticos. Los resultados muestran como la productividad económica del uso de uso de agua en la caña aumentó de 0,089 a $0,33 \$ \mathrm{~m}^{-3}$. La mecanización del cultivo de la caña ha disminuido los costes de erosión y aumentó el valor de los servicios ecosistémicos (SE) generados de 0,0036 a $0,0037 \$ \mathrm{~m}^{-3}$. Las áreas naturales, pastos y plantaciones de eucaliptos son los usos de suelo que generan mayor valor de los servicios ecosistémicos seleccionados, tanto por unidad de superficie $\left(\$ \mathrm{ha}^{-1}\right)$ como en relación al agua consumida. Los cultivos anuales resultan un uso de suelo más eficiente en la generación de valor de SE en relación a su consumo de agua que la caña de azúcar. A la escala de la cuenca hidrográfica, los cambios de usos de suelo han dado lugar a una mayor eficiencia económica de uso de agua, pero a una menor eficiencia de uso de agua en relación a las externalidades ambientales. Este efecto se produce a pesar de la mejora significativa en la eficiencia de uso de agua en la caña de azúcar y está asociada a la sustitución de pastos y cultivos anuales por parte de la caña. El análisis conjunto de la evolución de las prácticas de cultivo y la evolución de los usos de suelo apoya la interpretación de las implicaciones del cultivo de la caña de azúcar para el uso eficiente de los recursos a nivel de cuenca.

Los resultados de esta tesis resaltan la importancia del análisis de los vectores que determinan las prácticas agrícolas y su contextualización a nivel local para entender la eficiencia de uso de agua y evaluar la sostenibilidad de las producciones agrícolas. De la misma manera que la sostenibilidad de uso de agua no se define a nivel de parcela sino a escala de cuenca hidrográfica, la definición de uso eficiente de agua varía si se estudia a nivel de parcela o de 
cuenca, enfocado en la productividad física, económica o respecto a la generación de valores ambientales. La consideración de varias perspectivas nos permite entender mejor las implicaciones de los cambios en la producción agraria. No es sencillo transmitir esta complejidad a grupos de interés más alejados de la realidad agraria, como empresas y consumidores, que se basan en la unidad "producto" para evaluar la sostenibilidad de su actividad. Sin embargo, marcos metodológicos como la evaluación de huella hídrica, debidamente adaptados, nos ayudan a transmitir esa complejidad y crear estrategias coherentes para el uso eficiente y sostenible del agua.

Palabras clave: eficiencia de uso de agua, sostenibilidad de la producción agraria, prácticas agrícolas, evaluación de huella hídrica 


\section{SUMMARY}

Agriculture is the main land and water user in a world where water and land resources are limited and face important challenges to satisfy increasing global demands. At the same time it is a multifunctional activity that conditions several natural processes and is essential for human food security, development and the rural economy. In a globalized economy, consumer demand for specific products and economic forces may be the root cause of agricultural development and therefore of water use. Consumers and companies are increasingly relevant actors in water management through their consumption choices, purchasing decisions and creation of incentives. Nevertheless, these actors need tools and frameworks to reach their objective of contributing to more sustainable and efficient water use. In the move towards more efficient water use, several perspectives are needed. Not only less water use per unit, but also a consideration for the economic benefits and a valuation of the externalities of agricultural production can help provide insight into the basic question of what is the most efficient, socially valuable water use. This complexity needs to be understood and addressed by all stakeholders.

The goal of this research is to evaluate how the drivers of agricultural activity affect crop management and therefore its water use, water efficiency and sustainability. It explores the relationship between the product, the unit used in the economic realm, and the basin perspective, the socio-environmental unit. As a framework of analysis, the research uses the Water Footprint Assessment and the Water Footprint indicator. This is comprehensive indicator to look into the consumption of green and blue water resources and the indicator of pollution, the grey water footprint. This indicator is successively adapted and complemented to provide a fuller understanding of the implications of agricultural water use.

The research addresses three case studies with varying scopes and indicators. The first case focuses on ethanol production in North-eastern Brazil under rainfed and increasing irrigation. It considers physical and economic productivity of land and water use levels at the field scale. The second one looks into the effect of the agricultural policies on the sustainability of water use in a consumer product, coming from the perspective of a textile company to the agricultural sector making the link from the field to the river basin scale. The third one studies the development of sugarcane in a river basin in Sao Paulo state, Brazil, under changing crop management practices, and places the results of the evaluation within its context with the other 
land uses in the basin. In this case, the concept of ES-valuation is used as a tool in the consideration of the externalities of agricultural water use.

The results of the first case study suggest that, as irrigation levels increased, the physical and economic water productivity of sugarcane increases, at the expense of increased share of blue water footprint and higher grey water footprints per unit of ethanol. Rainfed production showed lowest total water footprint (green, blue and grey water footprint), 1,647 $11^{-1}$ of ethanol whereas full irrigation showed the lowest consumptive water footprint (only green and blue components) of $1,22511^{-1}$ of ethanol. If we consider also grey water footprint full irrigation average water footprint resulted in 1,758 $11^{-1}$ of ethanol. The main component of ethanol's water footprint was the sugarcane production stage, as water consumption in the industrial stage represents $1 \%$ of the total water footprint. Reuse of ethanol production's by-products, bagasse and vinasses contributed to lowering the water footprint of the final product, ethanol. Farmer's profit and economic productivity of water use was higher for higher water regimes, linked to increased crop yield and lower irrigation costs. Nevertheless, rainfed production showed similar economic productivity of water as lower irrigation levels. These results suggest that the tendency to increase irrigation in sugarcane fields can lead to higher physical and economic efficiency of water use. Nevertheless, these results are limited to the field scale, so no information is provided into the consequences at the basin scale of increased potential pollution or the high blue water demand that such irrigation developments imply.

In the second case study, it was found that the most relevant component of a consumer's product WF was the fibre production stage which showed the highest share of the total product's water footprint. Cotton-based fibres showed higher water footprint than cellulosebased fibres, 5,128 $\mathrm{m}^{3} \mathrm{t}^{-1}$ and 2,285 $\mathrm{m}^{3} \mathrm{t}^{-1}$ respectively. The subsequent study of cotton production stage brought the focus to the incidence of the Common Agricultural Policy (CAP) in determining farmer's behaviour and crop management practices. The cotton fibres' water footprint per ton increased by $50 \%$ on average as farmers cut down on their variable costs and yields decreased after the reform. Nevertheless, when these results were put in the basin context to evaluate the sustainability of cotton blue water footprint, it was found that the low relevance of cotton in the basin context provided little influence on water availability in the basin. Moreover, hydrological management from reservoirs was the most relevant factor in determining blue water availability in the basin and the maintenance of ecological flows.

The third case study is focused on rainfed sugarcane production in the Mogi Guaçu-Pardo river basin in Brazil in the period 2000-2012. It looks into two concurrent developments in 
sugarcane production: the change from manual to mechanized harvesting and land use changes in the region whereby sugarcane area grew over pasture and field crops. We study the effects of such developments over land and water economic productivity and consider a set of two ecosystem services to explore some relevant trade-offs, water provisioning service and erosion potential. In order to deal with uncertainties in key variables like erosion rates per land use or evapotranspiration from natural vegetation, eucalyptus and pasture areas, Monte-Carlo simulations were performed. The results showed how sugarcane's economic water productivity increased from 0.089 to $0.33 \$ \mathrm{ha}^{-1}$, linked to rise in sugarcane prices. At the same time ES generation per unit of land and water also increased, as erosion costs decreased linked to the extension of mechanized harvesting from an average of $35.5 \$ \mathrm{ha}^{-1}$ to $37 \$ \mathrm{ha}^{-1}$ and from $0.0035 \$$ $\mathrm{m}^{-3}$ and $0.0036 \$ \mathrm{~m}^{-3}$ respectively. Natural areas, pasture and eucalyptus plantations are the land uses providing the highest values of ES per unit of land and water. Annual crops, despite offering the lowest ES value per area (ha), offer relatively high water apparent productivity and ES value per unit of water use, and average of $31.2 \$ \mathrm{ha}^{-1}, 0.254 \$ \mathrm{~m}^{-3}$ and $0.0075 \$ \mathrm{~m}^{-3}$ respectively. At the basin level, the increase in sugarcane area over pastures and annual crops has led to lower water apparent productivity and lower returns on ES value per unit of water, despite the improvements linked to the mechanization of harvesting. The results show the effect of agricultural management practices on the economic and ES returns on land and water use in a particular production system. At the same time, the analysis with the rest of land uses at the river basin level puts the results in perspective, thus providing insight into the rationality of water and land allocation.

These results highlight the importance of looking at the local context of agricultural production to determine the water use efficiency and sustainability of agricultural production. The three case studies increasingly contextualize the product perspective, going from the field to the basin perspective, understanding the effect of the drivers of agricultural production on crop management practices and the need to consider issues like hydrological management, land use change and alternative land uses in the basin in order to look into the question of how efficient and sustainable water use is in agricultural products.

Key words: water use efficiency, sustainable water use, crop management, agricultural water use drivers 


\section{TABLE OF CONTENTS}

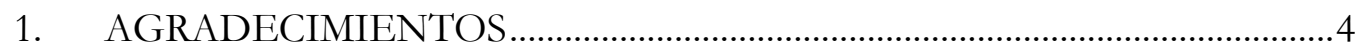

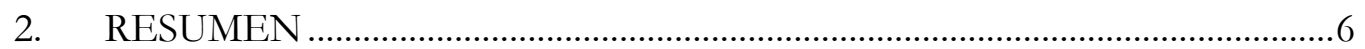

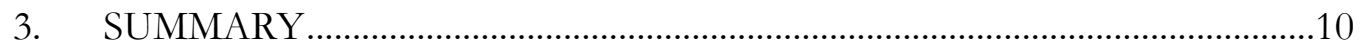

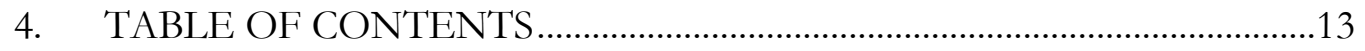

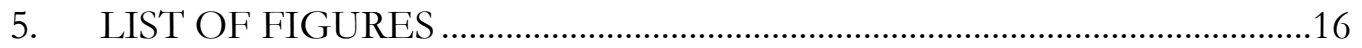

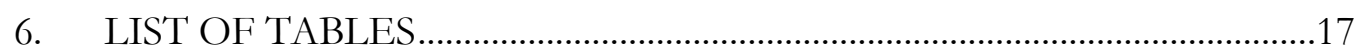

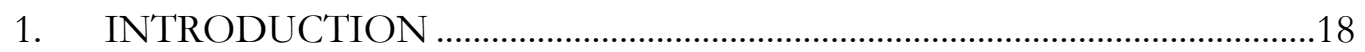

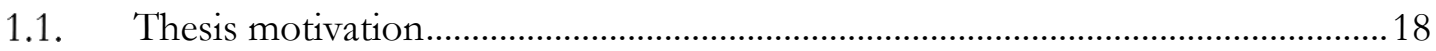

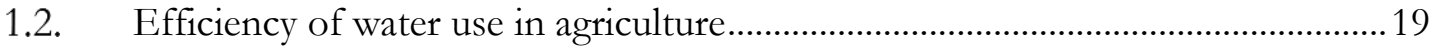

1.3. The role of corporate supply-chains in water management ..................................22

1.4. Water Footprint Assessment................................................................................2

2. RESEARCH OBJECTIVES, OUTLINE AND FRAMEWORK …................30

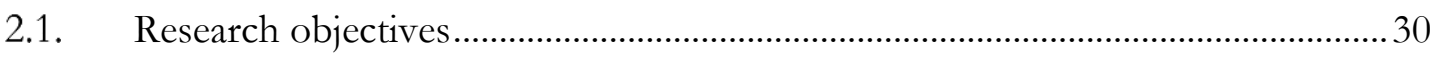

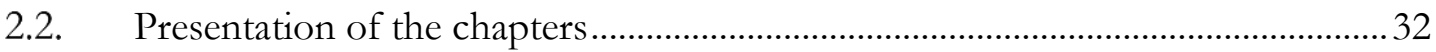

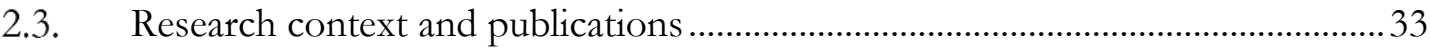

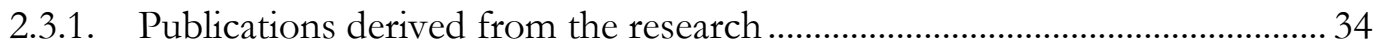

3. INCREASING EFFICIENCY IN ETHANOL PRODUCTION: WATER FOOTPRINT AND ECONOMIC PRODUCTIVITY OF SUGARCANE ETHANOL UNDER EIGHT IRRIGATION LEVELS IN NORTH-EASTERN BRAZIL.37

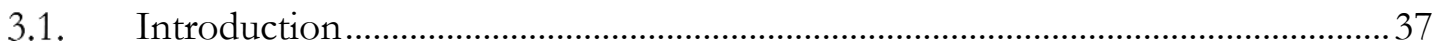

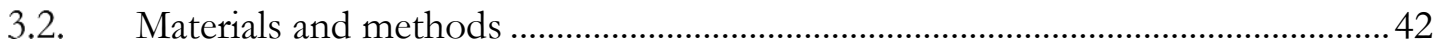

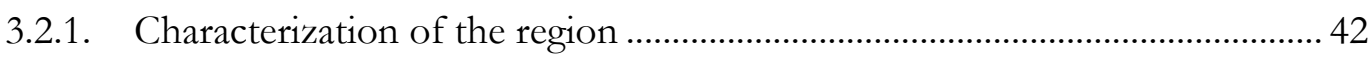

3.2.2. Characterization of the Production Systems .................................................. 43

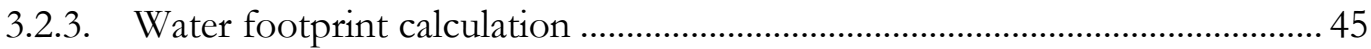

3.2.4. Economic evaluation of water footprint results ................................................ 48

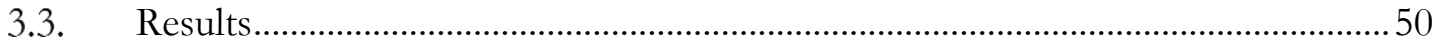


3.3.1. Ethanol water footprint results........................................................................ 50

3.3.2. Water economic productivity of ethanol production ........................................ 53

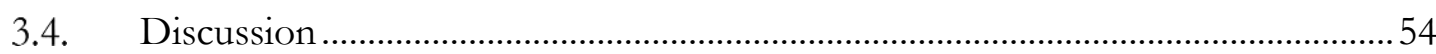

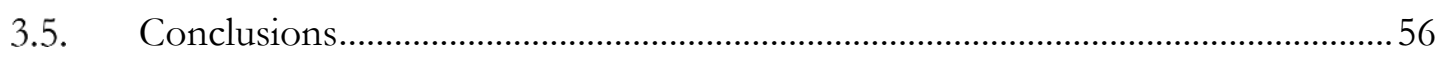

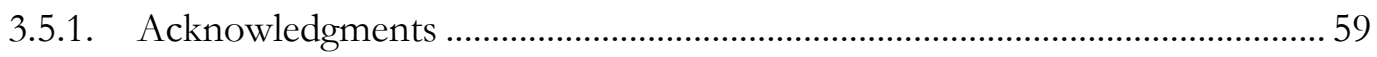

4. THE WATER FOOTPRINT ASSESSMENT OF A PAIR OF JEANS: INFLUENCE OF AGRICULTURAL PRODUCTION IN CONSUMER PRODUCT'S SUSTAINABILITY

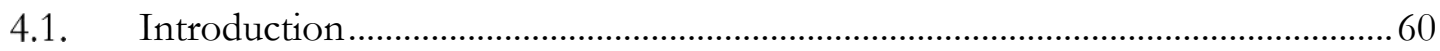

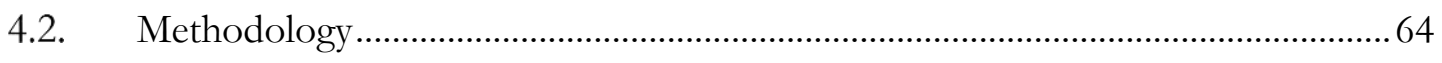

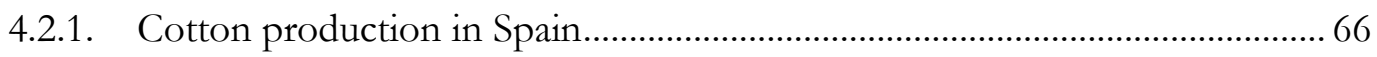

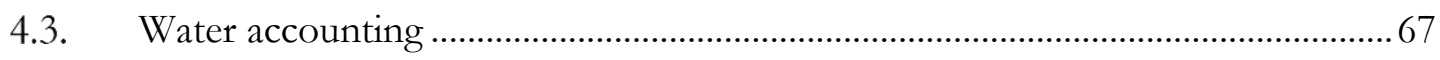

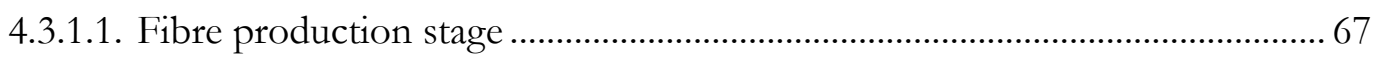

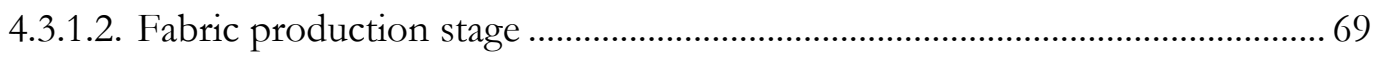

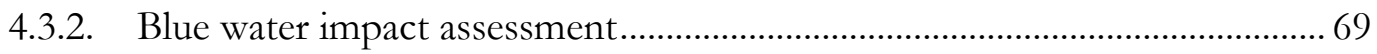

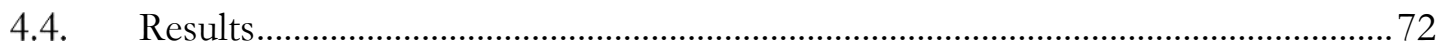

4.4.1. Water accounting ............................................................................................... 72

4.4.2. Blue water sustainability assessment ……………………................................. 80

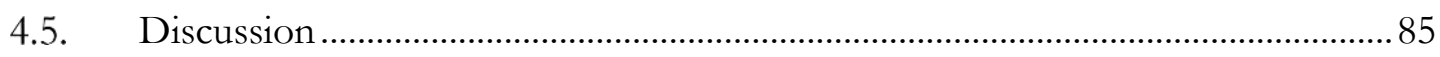

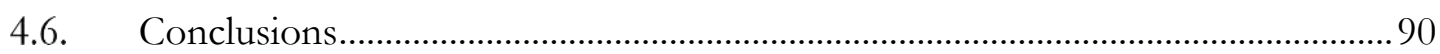

5. ECONOMIC AND ECOSYSTEM SERVICES VALUATION OF LAND AND WATER USE IN BRAZILIAN SUGARCANE UNDER EVOLVING MANAGEMENT PRACTICES AND LAND USE CHANGE ............................92

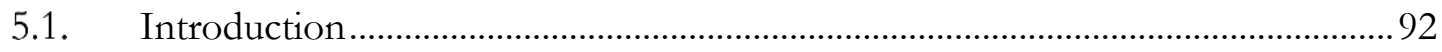

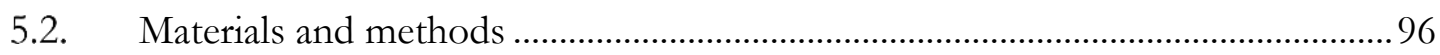

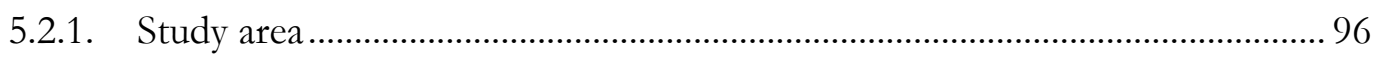

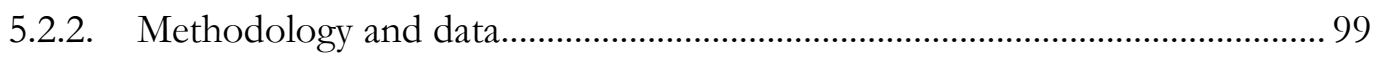

5.2.3. Water Footprint accounting, water productivity and ES valuation............. 100 
5.3. Results

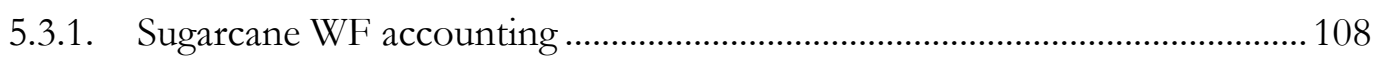

5.3.2. Water productivity in the MGP river basin ................................................... 111

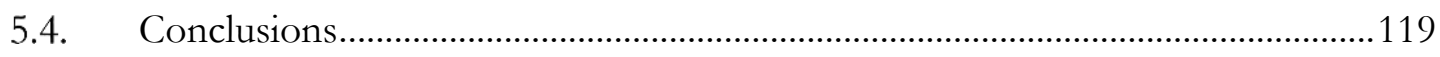

6. CONCLUSIONS OF THE RESEARCH ........................................................ 122

6.1. General conclusions of the work and research contributions............................122

6.1.1. Chapter 3: Increasing efficiency in ethanol production: Water footprint and economic productivity of sugarcane ethanol under 8 different water regimes in North-

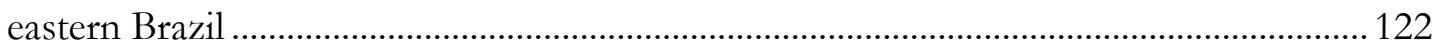

6.1.2. Chapter 4: The water footprint assessment of a pair of jeans: Influence of agricultural policies in consumer product's sustainability 123

6.1.3. Chapter 5: Economic and ecosystem services valuation of land \& water use in Brazilian sugarcane under evolving management practices and land use change 125

6.2. Final considerations 126

7. LIMITATIONS AND AVENUES FOR FURTHER RESEARCH .129

7.1. Methodological limitations

7.1.1. Conceptual limitations of the research

7.2. Avenues for further research 


\section{LIST OF FIGURES}

Figure 1.- Conceptual framework of the research

Figure 2.- Sugarcane cultivated are per micro-region. In red: Alagoas State. Source: IBGE

Figure 3.- Green, blue and grey WF of ethanol $\left(11^{-1}\right.$, left axis) and obtained yield (right axis) per irrigation level. Average 2009, 2010 and 2011

Figure 4.- Grey WF $\left(11^{-1}\right)$ per irrigation depth, year and vinasse use

Figure 5.- Total Profit (US\$ ha ${ }^{-1}$ ) and water apparent productivity $\left(\mathrm{US} \$ \mathrm{~m}^{-3}\right.$ ) per irrigation level and year. Colours indicate irrigation level (green rainfed, orange lower irrigation levels 50-150, red higher irrigation levels 200-350, blue full irrigation)

Figure 6.- System boundaries of the production chain for cotton and Lyocell fibres, data source per process, and type of water taken into account per stage. The colour of the arrows indicates the type of water consumed at each point (green water, blue water and grey water) 65 Figure 7.- Study areas and main rivers in the Guadalquivir, Guadalete, and Barbate basins 71 Figure 8.- Water footprint ( $\mathrm{m}^{3} / \mathrm{t}$, columns, left axis) and land productivity (LAP) (€/ha, line, right axis) per irrigation method for the years 2005 and $2009 \quad 76$

Figure 9.- Municipal cotton green and blue water footprints $\left(\mathrm{Mm}^{3} / \mathrm{y}\right)$

Figure 10.- Study river basin in Brazil and percentage sugarcane area in the municipal area97 Figure 11.- Average areas (ha) and percentage of basin area per land use type for the years 2000 and 2012

Figure 12.- Water Footprint Assessment framework and water apparent productivity and Ecosystem services valuation as part of the sustainability assessment phase

Figure 13.- Average and $5^{\text {th }}, 25^{\text {th }}, 75^{\text {th }}$ and $95^{\text {th }}$ percentiles of erosion costs in sugarcane $\left(1,000 \$ \mathrm{y}^{-1}\right)$

Figure 14 -Average and $5^{\text {th }}, 25^{\text {th }}, 75^{\text {th }}$ and $95^{\text {th }}$ percentiles of sugarcane ES value per unit of water $\left(\$ \mathrm{~m}^{-3}\right)$

Figure 15.-ES value generated per unit of water $\left(\mathrm{US} \$ \mathrm{~m}^{-3}\right)$ per land use type for the years 2000 and 2012 


\section{LIST OF TABLES}

Table 1.- Description of treatments, numbers and methods of irrigation, cultivated area (ha) and average productivity $\left(\mathrm{t} \mathrm{ha}^{-1}\right)$

Table 2.- Irrigation costs per ha and per mm, per irrigation system. Average of three years 49 Table 3.- Maximum, minimum and average green, blue and grey water footprint $\left(\mathrm{m}^{3} / \mathrm{t}\right.$ product) in each production stage and total WF per trouser $\left(\mathrm{m}^{3} /\right.$ piece)

Table 4.- Average green, blue and grey WF $\left(\mathrm{m}^{3} / \mathrm{t}\right)$ and standard deviation among municipalities

Table 5.- Main variables of the WSI ( $\mathrm{Mm}^{3} /$ month), WSI for the years 2005 and 2009 and main variables of the ending reservoir (Mm3/month) for the main body of the Guadalquivir river study area

Table 6.- Cotton water footprint $\left(\mathrm{Mm}^{3} / \mathrm{y}\right)$, blue water footprint of crop production $\left(\mathrm{Mm}^{3} / \mathrm{y}\right)$, total natural runoff $\left(\mathrm{Mm}^{3} / \mathrm{y}\right)$, total naturally available water $\left(\mathrm{Mm}^{3} / \mathrm{y}\right)$ average monthly WSI, average monthly water storage $\left(\mathrm{Mm}^{3} /\right.$ month), total outflow $\left(\mathrm{Mm}^{3} / \mathrm{y}\right)$ and average adjusted monthly WSI in cotton producing months (April-October)

Table 7.-Average Water Footprint of the fibres $\left(\mathrm{m}^{3} / \mathrm{t}\right)$ 86

Table 8 - Parameters used the estimation of water consumption per land use 106 Table 9.- Sugarcane area cultivated (ha), economic value generated (1,000\$/year), green and blue water footprint $\left(\mathrm{Mm}^{3} /\right.$ year), water apparent productivity $\left(\$ / \mathrm{m}^{3}\right)$ and total Ecosystem services value $(1,000 \$ /$ year $)$

Table 10.- Economic value $\left(\$ \mathrm{ha}^{-1}\right)$, water consumption $\left(\mathrm{m}^{3} \mathrm{ha}^{-1}\right)$ value of water provisioning $\left(\$ \mathrm{ha}^{-1}\right)$, erosion costs $\left(\$ \mathrm{ha}^{-1}\right)$ and value of ES $\left(\$ \mathrm{ha}^{-1}\right)$ per land use. Averages per municipality and year, $5^{\text {th }}$ and $95^{\text {th }}$ percentiles

Table 11.-Economic value ( $\$ 1,000 /$ year), WF $\left(\mathrm{Mm}^{3} /\right.$ year), value of water provisioning, Cost associated to erosion ( $\mathrm{R} \$ 1,000 /$ year), average (av.), $5^{\text {th }}$ and $95^{\text {th }}$ percentile (pc) values per land use class per land use class in the years 2000 and 2012 


\section{INTRODUCTION}

\subsection{Thesis motivation}

In a world where land and water resources are finite, there are questions about how to achieve sufficient food production in the face of population and economic growth, dietary changes and urbanization. The challenge faced by water resources management is how to achieve a balance between two opposing needs: on the one hand to satisfy an increasing demand from agricultural production and urban uses and on the other hand ensuring the ecological integrity of water systems and the future availability of water in adequate quantities and/or quality (de Fraiture et al., 2010). Additionally, water availability can be expected to decrease and to be more uncertain in various regions due to climate change (Foley et al. 2011). At a global level, some authors have proposed the term "safe space" as a concept to guide the efforts towards achieving such a balance in line with the "planetary boundaries" concept (Röckstom et al., 2009).

Agriculture is the largest water user globally and therefore solutions to address water scarcity globally need to address water use in agriculture (de Fraiture and Wilchens, 2010). At the same time, agricultural activity is key not only for food provisioning, but also for human and economic development (de Fraiture et al., 2010). Agriculture is also a multifunctional activity that, in addition to the production of goods, has implications for resources management and natural processes (Bryan et al. 2013). It plays an important role in determining the change of land use and has varying roles in other ecosystem processes like the regulation of soil and water quality, supporting biodiversity, climate regulation and carbon sequestration or cultural values, which in turn satisfy societal needs or sustain natural values (Power, 2010).

The effect that agriculture may have on the natural system depends on the extent of the cultivated surface and practices (Gordon et al. 2010). Agricultural practices, which by definition are carried out at the field level, may help to improve resource management and decrease negative environmental effects, like pollution from fertilizers or pesticides, e.g. through irrigation and fertilization practices, soil management and tillage, crop rotation or multicropping, etc. At the river basin level, irrigation activities condition hydrological and infrastructure management.

In relation to the hydrological cycle, the relation between agricultural management and water resources has effects at different scales. At the field scale, they can determine the partition 
between infiltration or runoff, determine the water balance and contribute or mitigate water pollution from fertilizers and pesticides (Locatelli and Vignola, 2009; Neill et al., 2013; Deasy et al., 2014). These relations can then be extrapolated at the basin level depending on the extent of agricultural area in the basin, and also through the determination and change of land use. It is for this relation that water management is directly linked to agricultural management and land use policy.

Agricultural activity is shaped by a number of drivers that include physical aspects such as climate change and human aspects like infrastructure, population growth, urbanization and consumption habits, globalization, trade, market access and policies, institutions and power relations (de Fraiture et al., 2010), that have a local, regional, national and/or international scale. For example, not only changes in agricultural policy itself have an influence on the sector, but also changes in rural development, trade and financial and energy policies. Agriculture is a dynamic activity, responsive to economic and policy incentives. Irrigation techniques, cultivated areas, crop selection and management techniques can change relatively quickly when incentives and capital (human and technical) are present. The resulting effects of these drivers will shape the agricultural sector and therefore its pressure on water systems. Therefore, there is a need to understand water use in agriculture and the implied trade-offs for water management of developments in the agricultural sector in order to achieve sustainable water management.

Several strategies have been proposed to deal with the challenge of food production, water security and integrity of natural systems (de Fraiture et al. 2010; Foley et al. 2011). Such strategies are oriented towards the increased productivity in rainfed and irrigated areas, closing yield gaps, enhancing diversity and production of ecosystem services besides food provision, shifting diets and reducing food waste along the food value chain, consider the social and institutional setting in the reform process, balancing the action of state and other social actors, including the private sector.

\subsection{Efficiency of water use in agriculture}

In the past, together with land expansion and productivity increases, growth in food production has been achieved by extending irrigation. However, in many regions the potential for irrigation expansion without threatening environmental sustainability will be limited (Jägermayr et al., 2016). The extension of rainfed agriculture may also be limited as planetary boundaries for land use are close to being reached (Steffen et al., 2015). Therefore, land and 
water productivity increases will be needed to increase agricultural production without exceeding natural limits and curbing the ability of ecosystems to support human activities by affecting the water system (Müller et al., 2012). Currently, the UN sustainable development goals (SDGs) (UN, 2017), which guide the international efforts for development for the next 15 years, explicitly acknowledge water in its $6^{\text {th }}$ goal and in particular goal 6.4 aims at "By 2030, substantially increase water-use efficiency across all sectors and ensure sustainable withdrawals and supply of fresh water to address water scarcity and substantially reduce the number of people suffering from water scarcity".

This thinking is the foundation for the "sustainable intensification" approach (Godfray et al. 2010), promoted by international agencies like FAO. This concept would call for increased production with environmentally-sustainable practices (Garnett et al., 2013). With such approaches the aim is to achieve more private and public benefits from water use. Pereira et al. (2012) propose that efficient water use would refer to maximizing beneficial water uses, increase of water productivity and minimization of water loss.

Some authors advocate the incorporation of soil water, or green water, into water management (Falkenmark and Röckstrom, 2006). The concept of green water refers to the precipitation water stored in the soil, in the vadose zone (Falkenmark and Röckstrom, 2006; de Fraiture et al., 2010). It is considered complementary to the so-called blue water, or the water stored in aquifers, rivers, lakes and reservoirs. It is this segment of the hydrological cycle that supports most of the world food production, by supporting rainfed agriculture (Mekonnen and Hoekstra, 2011). Moreover, the role of green water in water management is likely to gain prominence with the increasing variability in the availability of water as a consequence of climate change (Röckstrom 2009). If this relevance is acknowledged, some of the challenges around water resources may be addressed differently. Increasing agricultural production may not always come from increasing irrigation but from a better management of soil water by blending clear-cut frontiers between green and blue water, i.e. rainfed and irrigated agriculture, through, for example, rainwater harvesting (De Fraiture and Wilchens, 2010). Improving green water use may provide an opportunity to increase crop production in an alternative manner to irrigation expansion, by means of improved cultivation practices (Hoff et al., 2009; Jägermayr et al., 2016).

In irrigated agriculture, efficiency and productivity are concepts that, although seemingly clear, actually are applied to various concepts (Foster and Perry, 2009) depending on the variables being considered. Efficiency implies a relationship between an output and an input 
(Pereira et al., 2012). At field level, we may consider a number of water flows relevant to different issues. To understand water use efficiency and productivity, it is important to consider the separation between consumptive and non-consumptive water use, and between beneficial transpiration and non-beneficial evaporation. (Foster and Perry, 2009). Infiltration and runoff can be considered as losses at the scale of the field or irrigation system. However, at the basin level this may not be the case (Van Halsema and Vincent, 2012), since return flows may feed aquifers or surface water bodies. We can then make a distinction between recoverable and nonrecoverable fractions of these return flows. If we discount such non-consumptive water uses the focus on the increase of water efficiency and irrigation water efficiency can be understood differently on decreasing the consumptive use and increasing beneficial evapotranspiration (Foster and Perry, 2009). This can be done through crop management practices, like mulching, use of drip irrigation technologies, adequate nutrient and pest management or reducing evaporation from weeds (Chukalla et al. 2015).

Such an approach is useful to determine the efficiency of water use in irrigation at the irrigation system (Perry et al., 2009) or the river basin scale (Hoekstra, 2014), making a link to hydrological management. While at the field level a more common interpretation of irrigation efficiency is needed for the farmer and irrigation system operation (Garcia-Morillo, et al., 2014), the evaluation based on water consumption or non-recoverable fractions can make a better link to hydrological management and the evaluation of sustainable use of water resources (Hoekstra, 2014).

The argument for increasing water use efficiency may reduce water use, thus potentially liberating water and land resources for other uses. However, some authors warn against this point of view since there may be rebound effects (Lopez-Gunn et al. 2012) unless total water consumption in the catchment is balanced with water availability. In the case of green water use there also needs to be some limit with regard to its use, which is related to agricultural land expansion. It is argued that since green water use is linked to land use, it cannot be allocated to other river basin uses within a short period of time, so its opportunity cost is lower than blue water resources (Garrido et al., 2010, Lathuillere et al., 2016). Nevertheless, there are many positive ecosystem services linked to land use and green water use that may be hampered by agricultural land expansion and therefore, at a certain scale there is also an opportunity cost for green water use and would be linked to ES provision at the basin level.

Another definition of efficiency at the river basin level can be allocation efficiency, considering the net values from all sectors and addressing pertinent externalities (Beltran and 
Velazquez, 2015). This implies the comparison of the different water uses in a river basin. Such an allocation efficiency moves out of the farmer's scope and leads into the management and policy arena, being most useful for water management, land use and rural development policy making.

Other definitions of water productivity relate water consumption to economic or social variables instead of crop yield (Giordano et al., 2017). This is also linked to the consideration of different land uses in a river basin and comparing the outcomes of their water consumption (Van Halsema and Vincent, 2012). The downside of such assessments, however, can be that, when introducing prices or other economic variables, the resulting water productivity is then dependent on market changes, and the methodological challenges to valuate water consumption from users other than agriculture (i.e. hydropower or managed forests). These evaluations allow the identification of the social, ecological and economic value of water use. Therefore, water use efficiency or water productivity can be tailored to provide information on different water management perspectives and to improve water use in an area (Giordano et al., 2017). This way, they can provide a water indicator for sustainable intensification strategies.

\subsection{The role of corporate supply-chains in water management}

Trade in agricultural commodities is also part of the globalization process that has taken place in recent decades (Dalin et al., 2012). International food trade plays a highly relevant role in the food and energy security of many countries. This fact can bring into the picture a broader perspective for addressing water resources management, if we acknowledge the connection between producers' and consumers' demand (Hoekstra and Chapagain, 2007).

The consideration of product value chains and water as a global commodity makes apparent the involvement of many actors previously disregarded in water resources management. Relevant stakeholders like producers, processors, traders and consumers will be physically distant from the locations where water is consumed, but may play a defining role in shaping water use and therefore, in exacerbating or alleviating water scarcity (Allan, 2003). The relationships among these actors can drive the agricultural supply chain and condition production choices.

In a globalized economy, because of economic globalization, effective decision making falls, in many cases, under the corporate umbrella rather than being taken care of by national or regional governments (Lambooy, 2011). From a company point of view, risk can be 
understood in terms of physical, reputational or regulatory risks. In the food sector, retailers increasingly consider sustainability issues for risk management, long-term business security, stakeholder pressure and corporate social responsibility (Seuring and Gold, 2013). In order to address fully potential risks, companies increasingly understand the relevance of looking at their suppliers with regard to their economic and environmental performance. This leads to the introduction of standards and indicators in the focal companies and then through their supply-chain to the rest of the value chain (Seuring and Muller, 2008).

Managing information from within the company and for communication with suppliers is key for implementing sustainable management and therefore requires tools and frameworks of analysis (Seuring and Muller, 2008). Environmental certification schemes and requirements for products and suppliers are the most common and preferred strategies for environmental management along the supply chains (Styles et al. 2012). The same authors point to an increased use of supplier benchmarking and performance standards to drive supplier improvement.

The same approach is seen in the case of water resource management. As companies involve themselves in corporate sustainable water use, there is a switch from a consideration of water as an input, and therefore considering only direct water use and water pollution as the main issue, to understanding more comprehensively their relation to water resources, also considering water use in the supply chain (Martins, 2014). A further step is the understanding of water scarcity and management in the sourcing river basins. This process has eventually lead to the emergence of concepts like "water stewardship". This concept proposes several changes in the approach towards sustainable water use, like the shift from direct operations to supply chain thinking, or from a cost-reduction, risk-avoidance approach to a proactive, engagementfocused approach to water governance. The first step would be to measure and reduce water use in their direct operations, followed by the setting of benchmarks and standards of water use for suppliers. Increasingly, water-related risk is a key topic for the private sector, and many key multinational companies are evaluating their water-risks (Daniel and Sojamo, 2012). Nevertheless, some studies warn against the excessive or unrestricted involvement of corporations in water governance by means of these concepts, given the power asymmetries between corporations, farmers and governments (Sojamo, 2015).

\subsection{Water Footprint Assessment}

The water footprint (WF) is an indicator to assess the pressure that human activities put on water resources (Hoekstra et al., 2011) in quantity and quality, reflecting the resource base 
needed for an activity. Its conceptual base is founded on the Virtual Water concept (Allan, 2003), the concept of human appropriation of natural resources and its environmental limits. In this regard, it approximates the ecological and carbon footprints (Hoekstra and Wiedmann, 2014) and has been proposed as part of a "family" of footprint indicators to assess human pressure on natural resources (Galli et al., 2012). The ultimate goal of the application of the method would be to achieve efficient, equitable, globally fair and environmentally sustainable water use (Hoekstra et al., 2011; Hoekstra, 2014). The WF can state the direct and indirect demand on global water resources by an activity or a product. It is spatially and temporally explicit. The method considers both water consumption and pollution of the activities in question and upstream in the value chain. The water footprint, as an indicator, being the aggregation of the consumption of several activities, can also be calculated for a region, a country, a river basin, a consumer or an organization (Hoekstra et al., 2011). The concept and its methodological application can be a flexible tool to use in the evaluation from the water resources point of view for a wide range of situations with varied goals.

The indicator is articulated in a methodological framework: the water footprint assessment (WFA). This methodology considers four phases: (1) goal and scope definition; (2) water footprint accounting; (3) sustainability assessment; and (4), a final response formulation phase (Hoekstra et al., 2011). After the goal and scope definitions, the WFA estimates the green, blue and grey water footprint of each of the processes included in the study. Green and blue water footprints refer to the consumption of green or blue water resources, so that they are not available for other users of the river basin or not within a reasonable period of time. This includes the estimation of evapotranspiration from crops and vegetation, evaporation from open water or return flows ending in the sea or other river basins. Blue water resources are the freshwater resources from rivers, lakes and aquifers. Grey water footprint is a measure of the use of the capacity of water bodies to assimilate pollution. It is estimated also in volumetric terms, as the volume of water that is needed to be present in the water bodies to ensure the assimilation of the pollution loads reaching it so that concentration levels remain below environmental standards. This way, the WF offers a broader view of water resources appropriation than just water withdrawal accountings, traditionally used for water resources management and planning (Hoekstra et al. 2011).

The next phase of the methodology, the sustainability assessment, aims at contextualizing the accounting results and assess the environmentally, social and economic sustainability of each water footprint component, green, blue and grey. As such, the sustainability and efficiency 
of each water footprint component (the combination of water footprint type (green, blue, grey), place and time of occurrence) is evaluated based on the principles of environmental, social and economic sustainability. This includes the following: consumption or quality demand does not exceed water availability, (including environmental minimum flows and water quality standards), basic human needs for water are met, fairness of consumption among users is considered and economically efficient use of water is taken into account (Hoekstra et al., 2011).

In its first applications, water issues were addressed from a primarily global perspective, understanding that in a globalized economy, geographically or temporally distant consumption and production processes have an effect on water resources. Nevertheless, as the nature of water impacts is local, the water footprint is related to the local availability of water.

Research in this field has greatly developed in recent years (Lovarelli et al., 2016; Hoekstra, 2017), evolving from a primarily global focus and quantification of global WFs and virtual water trade (Hoekstra and Hung 2002; Hoekstra and Chapagain, 2007; Hoekstra and Mekonnen 2012) to more local analysis and quantification focused on specific products (Chapagain and Orr, 2009; Jefferies et al., 2012; Ercin et al., 2011) and applications at lower geographical scales like the national level (Van Oel et al. 2009; Bulsink et al., 2010; Garrido et al., 2010, CTA, 2015 or Chouchane et al. 2015), the river basin level (Aldaya and Llamas, 2008; Brown et al. 2009; Dumont et al., 2013; Zhuo et al., 2016b or Mekonnen and Hoekstra 2016) or the city level (Huang et al. 2015; Sun et al. 2016; Vanham et al. 2016a). From the point of view of organizations, there are several examples of application from the private sector point of view (Jefferies et al., 2012; Franke and Castro, 2013).

Another common perspective is applying the WFA from the geographical perspective, but looking from the consumption point of view (van Oel et al., 2009; Zhang et al., 2011; Ercin et al., 2013). This approach focuses on the water footprint of those products that are consumed within the geographical area, from which some will be produced in that same area and some will be imported. The number of studies looking at the water footprint of consumption patterns (Vanhan et al., 2013; Ercin and Hoekstra, 2014) or diets could also be considered as part of this perspective (de Blas 2016; Vanham et al., 2016b).

Another approach for the calculation of water footprints, instead of the bottom-up approach is the top-down approach, which is based on the estimation of water use at level of economic sectors instead of on a product basis (Feng et al., 2011). This approach is mostly used in studies using Environmental Input-Output tables and more recently in Multi-Regional Input 
Output Analysis (Velázquez 2006, Zhao et al. 2009; Feng et al., 2011; Zhang et al., 2011) and is also applied at various geographical scales. This approach is very strong for the analysis of the WF of consumption or to analyse the resource base of the different economic sectors.

The water footprint assessment framework can also be a tool for evaluating the implications of other policies on water resources, like trade (Garrido et al., 2010; Fader et al., 2011; Lathouillere et al. 2014) and agricultural development (Cazcarro et al., 2014) or energy policies (Gerben-Leenes et al., 2009; Hardy et al., 2012; Mekonnen et al., 2015a).

The sustainability assessment phase is at present not fully developed. Studies have focused particularly on the environmental sustainability of the water footprint and the economic and social sustainability assessments have been less numerous. Blue water scarcity at a global level was first calculated in Hoekstra et al. (2012) at the river basin level, and later further improved in Mekonnen and Hoekstra (2016). This water scarcity level allows the identification of blue water footprint hotspots in which the consumption of blue water resources exceeds the blue water availability in the area. Within this context blue water availability is defined as the natural runoff in an area minus environmental flow requirements (Hoekstra et al., 2011). Grey water footprint's sustainability is evaluated based on the water pollution level. This indicator reflects the total grey water footprint in an area against the runoff, in order to evaluate if the assimilation capacity of the river has been fully consumed (Liu et al., 2012; Mekonnen and Hoekstra, 2015c).

In addition to this, the environmental sustainability of green water footprints, though conceptually framed and structured, is challenging in its practical application (Schyns et al., 2015), since it implies the calculation of the fraction of terrestrial ET that should be reserved for environmental purposes like biodiversity conservation. Few studies have applied it in practice (Palhares and Pezzopane, 2015; CTA, 2015; Pellicer-Matinez and Martinez-Paz, 2017) and the approach has usually been its assessment through indirect effects of land use change (Miguel-Ayala et al., 2016, Salmoral et al., 2016). Schyns et al. (2015) review and synthesize several indicators for green water scarcity, distinguishing between relative and absolute indicators for green water availability and scarcity.

The social implications of the water footprints have been discussed in terms of employment associated to the crop cultivation (Novo et al., 2015, Munro et al., 2016) or looking at water supply availability for users (Mekonnen et al., 2015). Some few first attempts have been made to apply the full extent of the method (Mekonnen et al., 2015; Pahlow et al., 2015). 
As part of a framework for sustainable water use benchmarks have been proposed to achieve efficient water use (Hoekstra, 2014). To-date, benchmarks have been proposed based on a volumetric unit water footprint per product weight $\left(\mathrm{m}^{3} \mathrm{t}^{-1}\right)$ at the global level, which contribute to the discussion on global allocation of water (Mekonnen and Hoekstra, 2014). At a lower scale, Zhuo et al. (2016a) calculated national benchmarks for Chinese wheat production according to several climatic and management practices. However, the definition of efficient water use levels in this field can still be better developed.

In order to improve the usefulness of the indicator, some authors have proposed to add an economic perspective by looking into the economic value generated per unit of water use (Garrido et al., 2010) and thus termed the indicator as water apparent productivity. This approach, carried out based on the market price of the resulting product in terms of monetary benefit per water volume consumed [e.g. $€ \mathrm{~m}^{-3}$ ] has been further utilized in the works of for example Fulton et al. (2014), Chochuane et al. (2015), Novo et al. (2015) or Munro et al., (2016). By doing so, what we are measuring is not the price of water but the value obtained for that specific product. This perspective further adds to the indicator and has been used in the discussion regarding the most efficient water allocation in a river basin. The water apparent productivity indicator offers its biggest contribution in comparing uses and providing support for decision making in water allocation. However, this approach reflects the value of water based on the market value of the product and not on the full value of water (Rogers et al., 2002). Economic and environmental externalities are missing in this approach.

The water footprint assessment provides a useful link between the ecological and socioeconomic systems, since it is helps to make the link between products and the river basin. In this regard, it helps to provide consumers and companies with narratives that increase their awareness. It has been described as a pervasive concept to bridge the gap between different stakeholders (Lopez-Gunn et al., 2012) and is a powerful communication and awareness raising tool. This methodology can help companies to understand their water consumption and pollution and have a more holistic water management (Martins, 2014; Sojamo, 2015).

Nevertheless, the methodology has been contested. Many of the criticisms around WF have primarily been criticisms on using a single metric for water assessments (Wilchens, 2011, 2014; Perry, 2014, Fereres et al., 2016). By measuring water in physical terms, it is difficult to extract conclusions about the most economically efficient use, or more socially desirable uses in an area. Water Footprint reduction may not be the social optimum. There may be net social gains to be achieved from a limited overexploitation or pollution in contrast to the vision of a 
water pollution-free world (Wichelns, 2011). Furthermore, it has been highlighted that unique metrics do not provide sufficient information for policy making (Chenoweth et al., 2013; Perry, 2014).

Some authors remind their readers of the need to consider the socio-institutional setting that leads to a particular water use regime in an area, in order to avoid making prescriptive recommendations on a weak basis that may lead to environmentally undesirable situations (Roth and Warner 2008; Boelens and Vos 2012; Beltran and Velazquez, 2015). Roth and Warner (2008) point out that every decision has a political side, and particularly in relation to trade, energy and food security realms, and alert their readers to the complexity of water resources and the difficulty of making recommendations on water use or trade based on global perspectives. Boelens and Vos (2012) and Guzman et al., (2017) warn against the dangers of overriding traditional water uses, promoting dominant water discourses over spheres free from them until now and falling into environmentally injust situations. Beltran and Velazquez (2015) argue that water footprint concepts do not consider institutional or power geometries, and as such do not question the structural basis that leads to the identified water issues. It would be a narrative that stays at a normative level. Several studies would fit into such an argument, for example in Chapagain and Orr (2009), Gerben-Leenes et al., (2013) but it is also true that the water footprint has been successfully used to analyse also the social and institutional setting leading to a specific situation (Mekonnen et a., 2012; Novo et al., 2015; Zhuo et al., 2016b).

Hoekstra (2014) proposes a mechanism for sustainable water use by means of the establishment of water footprint caps per river basin, "reasonable" benchmarks for the main crops to achieve efficient water use and the identification of "fair share" of water footprints of consumption for equitable water use. Water footprint caps per river basin and the evaluation of the product water footprint against global benchmarks represent the most explicit statement of water footprint discourse being inserted in the narrative of a world with environmental limits.

Managing water resources involves managing human activities and existing interests, so in consequence, any decision will involve some trade-off and a change in the behaviour of stakeholders. In order to manage the trade-offs, we need to make them visible, and preferably quantify them. However, to date it remains challenging to adequately reflect the complexities and the influence of the various drivers on water use efficiency and sustainability at the different scales, from field to river basin to global level. 
For the methodology to be fully useful for policy making, it needs to be used in a way that reflects the complexities of water resources management and incorporate an understanding of the drivers of the agricultural sector and the local context. In many cases, social problems around water are entangled and difficult to address without high social, economic or political costs. In some cases, however, such problems could be tackled with relatively small reallocations and recognition of the social costs, but such a solution faces too strong a resistance from key stakeholders (Lopez-Gunn et al. 2013). When making this link between specific products and a water conflict, it could be possible to change the incentives that lead to the situation. Indicators like the water footprint can be used to convey complex information in a simple way, enabling the involvement of actors out of the water-sphere or the agricultural sphere to participate in water management and allow for a change of incentives.

Indicators should be able to convey adequate information so that relevant stakeholders like companies or consumers can also contribute through their purchasing decisions to improving the use of water resources, while at the same time being able to deal with the complexities and the conflicting goals of the various stakeholders. Therefore, there are still issues to be resolved the definition of appropriate indicators and metrics that can help to understand the influence of various drivers of agricultural production in water management with a local perspective. 


\section{RESEARCH OBJECTIVES, OUTLINE AND FRAMEWORK}

\subsection{Research objectives}

The goal of this thesis is to evaluate the environmental performance of agricultural production in terms of water use, water efficiency and economic productivity. The research evaluates the impact of external drivers of agricultural production (intensification, agricultural and environmental policies) that affect crop management practices and subsequently the efficiency of water use at the product and river basin level. It aims at contributing to the debate on indicators for water use efficiency and sustainability in agricultural products. This is done in consideration of the relevance of green water resources and water pollution together with blue water resources for a full understanding of the appropriation of water resources for agricultural use. The work looks into the integration of both product and basin perspectives, in order to make the link between the economic system, based on the product perspective, and the environment, managed at the river basin level (figure 1). Water footprint has been proposed as a holistic concept and articulated in a methodology to be used at all scales. As a secondary goal, the research tests the WFA as a method for the evaluation of the efficiency of water use in agricultural production, suggesting solutions to the issues identified.

More specifically, in chapter 3 the focus is the study of an agricultural product and the development of irrigation. The following research objectives are addressed:

- Characterize the ethanol production from sugarcane in North-eastern Brazil including the use of by-products of the industrial stage.

- Evaluate how increased irrigation of sugarcane affects the physical and economic water productivity in sugarcane cultivation

- Discuss the implications of such developments for future environmental sustainability of sugarcane production.

Chapter 4 looks into the integration of the product perspective in the river basin analysis (in the Guadalquivir Basin, Spain) and the sustainability assessment of blue water use:

- Evaluate the water use in a consumer product - cotton or cellulose fiber jeans-and in physical and economic terms

- Analyse the relationship between blue water use efficiency at field and basin level. 

FOOTPRINT AND ECONOMIC PRODUCTIVITY OF SUGARCANE ETHANOL UNDER EIGHT IRRIGATION LEVELS IN NORTH-EASTERN BRAZIL

- Evaluate the effect of hydrological management in sustainability of blue water use in the Guadalquivir river basin and the reflection of this effect on the blue water scarcity index.

- Understand the extent to which cotton prices and agricultural policies (e.g. Common Agricultural Policy) change the water footprint assessments of the manufactured products made from agricultural raw materials.

Chapter 5 deepens the analysis by looking at a different sugarcane production system, based on rainfed production, and analyse the influence of environmental policies on sugarcane's production water use efficiency and land use developments on water use efficiency at the river basin level

- Examine the relationship between water use efficiency in economic terms at the field and basin level, including green water resources.

- Contextualize in economic and environmental terms sugarcane's water use in respect to other basin land uses

- Evaluate to what extent the concept of ecosystem services (ES) can contribute to understanding the trade-offs of land use development and water use efficiency.

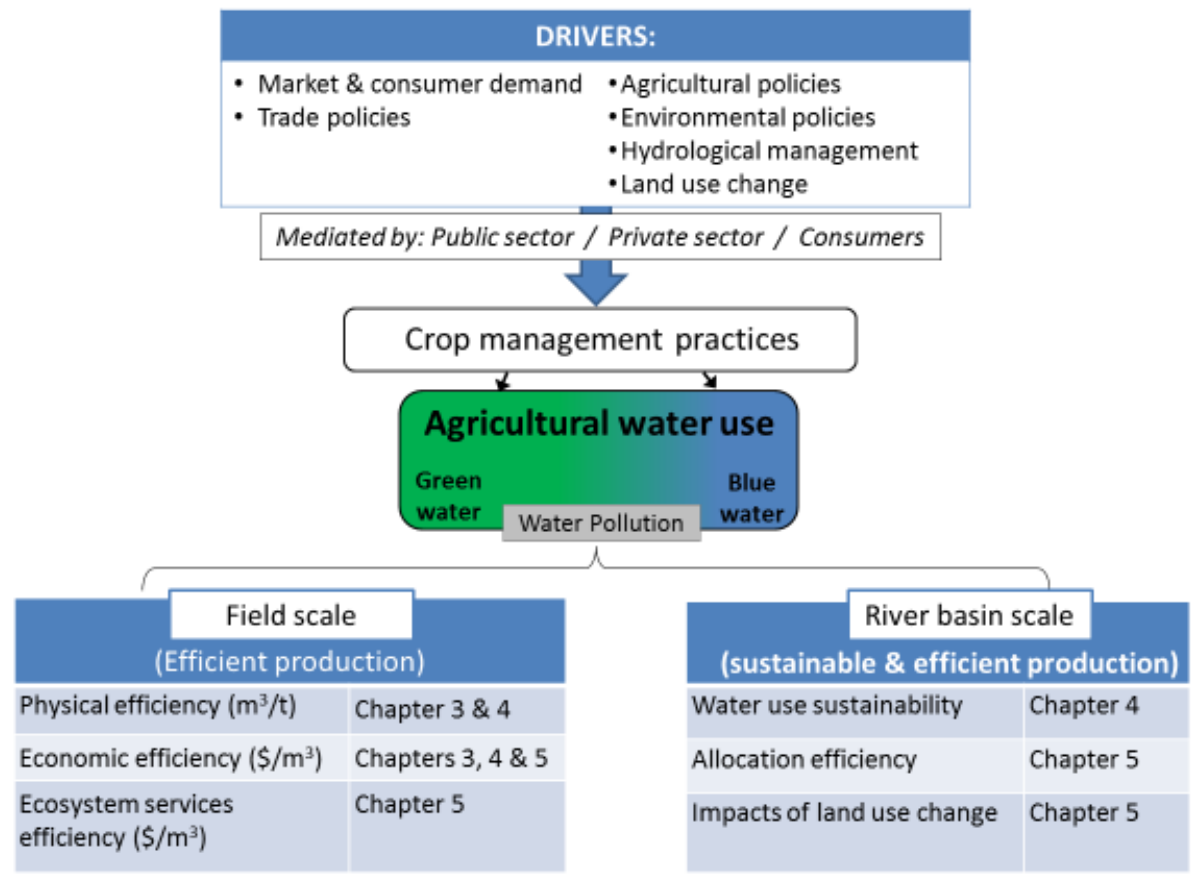

Figure 1.- Conceptual framework of the research 

FOOTPRINT AND ECONOMIC PRODUCTIVITY OF SUGARCANE ETHANOL UNDER EIGHT IRRIGATION LEVELS IN NORTH-EASTERN BRAZIL

\subsection{Presentation of the chapters}

The following three chapters discuss the developments in agricultural water productivity and sustainability under the influence of drivers of agricultural water use that affect crop management practices. To this end the research uses the water footprint assessment as the tool to analyse such influence at the product and river basin levels. The research discusses the concept of water use efficiency from a physical and economic point of view.

Chapter 3 illustrates how the tendency to increase irrigation in the production of sugarcane for ethanol in North-eastern Brazil will affect green and blue water productivity, in physical and economic terms. Such a development leads to a higher water and land productivity linked to higher yields and profit per hectare (ha), but comes at the expense of a high blue water use per ha, an increased share of the blue water footprint and a higher grey WF. However, this analysis is made at the field level, and thus does not provide information on the sustainability of water consumption at the basin level or the relative efficiency of water use in sugarcane as compared to other land uses.

Chapter 4 analyses a consumer product: jeans based on cotton production or a cellulose fibre. It shows a textile company's path along the value chain in order to understand water use in their products and its sustainability. It brings the focus from the consumer product to the agricultural production in an example of cotton production in southern Spain. It also explores the need to contextualize values per unit of product with the local drivers of agricultural production and with the basin situation to assess water use sustainability. It does so by showing, on the one hand, how the incentives of agricultural policies condition the farmers' choice of management practices and how this reflects on the efficiency of water use, and on the other hand, the need to consider hydrological management to evaluate water scarcity and sustainability. Adding the basin perspective to the field analysis helped us visualize the relevance of the results and identify some drivers of agricultural water use efficiency in physical and environmental terms and the sustainability thereof.

Chapter 5 builds on the previous chapter in order to analyse the evolution of sugarcane production in one river basin in São Paulo, Brazil. This way, after looking into the productivity of water and land use in economic terms and the valuation of its externalities with a set of water and land ecosystem services. The results are subsequently put into the basin context by looking into the main land use changes in the area. It evaluates the relative efficiency of water use in sugarcane against the existing land uses, including natural areas. This chapter also looks 
CHAPTER 2. INCREASING EFFICIENCY IN ETHANOL PRODUCTION: WATER FOOTPRINT AND ECONOMIC PRODUCTIVITY OF SUGARCANE ETHANOL UNDER EIGHT IRRIGATION LEVELS IN NORTH-EASTERN BRAZIL

into one of the drivers of sugarcane production: the evolving environmental policy, in which the sector mechanizes its harvesting technique for environmental and economic reasons.

\subsection{Research context and publications}

This research has been carried out thanks to the funding of the Water Observatory of the Botín Foundation and the CEIGRAM, research centre of the Universidad Politécnica de Madrid (UPM), which supported annual consecutive research in the projects "Extension on the analysis of the water footprint and virtual water trade in Spain", "Water and food security in Spain" and "Water and food security in Latin America". The Water Observatory has as its goal the promotion of innovative, science-based approaches to water management with an interdisciplinary approach. Its members form part of two teams, one based in the CEIGRAM and the other based in the faculty of Geology of the Complutense University of Madrid. Formally established in 2008, the water observatory has contributed to the promotion of research talent and the generation of innovative ideas on water governance and water resources management in Spain. It has also contributed to the public discussion on water management by introducing ground-breaking approaches and serving as a space for discussion and dissemination of such ideas. This has been the main learning experience for this thesis, including the seminars, courses and workshops organized by the Foundation. Chapter 3 was conceptualized in the year 2011 in a collaboration with Embrapa's researcher A. D. Santiago during his stay as guest researcher at CEIGRAM and concluded after field visits in the year 2013. Chapter 4 is the result of collaboration between the Botín Foundation and El Corte Ingles - and the technological centre for the textile industry AITEX and four additional textile and cellulose fibre producers ${ }^{1}$, which lead to this application of the methodology in their supply chain.

Two research stays at the socio-environmental research group of the Environment and Energy Institute from the University of São Paulo, (IEE-USP) have greatly contributed to this work. The visiting stays took place in August 2013 thanks to the grant for international guest researchers of the USP with the prof. P. Jacobi where the conceptual foundations of sustainability science of the present thesis were stablished, gaining insight on environmental governance from the perspective of sociological sciences. It was subsequently extended in

${ }^{1}$ The companies Tejidos Royo, Textil Santanderina, Tavex and Lenzing kindly collaborated supplying relevant data for the analysis. 
CHAPTER 2. INCREASING EFFICIENCY IN ETHANOL PRODUCTION: WATER FOOTPRINT AND ECONOMIC PRODUCTIVITY OF SUGARCANE ETHANOL UNDER EIGHT IRRIGATION LEVELS IN NORTH-EASTERN BRAZIL

October to December 2013 thanks to the grant for short research stays of the Universidad Politécnica de Madrid. This research stay formed the basis for the development of chapter 6 with prof. P. Sinisgalli. Also in 2013 a short trip to EMBRAPA - Nordeste thanks to the EMBRAPA fund for guest international researchers allowed me to visit the sugar-ethanol mills and the sugarcane fields and prepare chapter 3 of this thesis together with Embrapa researcher A. D. Santiago.

The last steps of this research were took place during the years 2014 and 2016 with me as part of the Water Footprint Network team located in the University of Twente, Enschede, The Netherlands. In this final stage, the thesis was research was strengthened with the incorporation of Dr. M. Pahow as thesis co-supervisor. The Water Footprint Network is an international organization whose goal is to promote sustainable, efficient and fair use of water resources. To that end, it promotes, develops and disseminates the Water Footprint Assessment concept and methodology. Its work is carried out together with its partners; governments, private sector and consumers from all over the world. This has enabled me to gain further insight into the understanding of water management from different stakeholders, like agricultural producers, environmental consultancies, private companies, public agencies or financial institutions, gaining further understanding of the full potential and limitations of this concept and its applications.

\subsubsection{Publications derived from the research}

Chapter 3 has been published as:

Chico, D., Santiago, A. D., Garrido, A. (2015) “Increasing efficiency in ethanol production: Water footprint and economic productivity of sugarcane ethanol under 8 irrigation levels in North-eastern Brazil”. Spanish Journal of Agricultural Research Vol 13, No 2.

Statement of Authorship: Chico contributed to the preparation of the data, method selection, interpretation and analysis of the data and led manuscript writing Santiago provided the data, and contributed to the analysis, Garrido contributed to the analysis, provided assistance to define goals and concept and manuscript writing.

Chapter 4 has been published as: 

FOOTPRINT AND ECONOMIC PRODUCTIVITY OF SUGARCANE ETHANOL UNDER EIGHT IRRIGATION LEVELS IN NORTH-EASTERN BRAZIL

Chico, D., Garrido, A., Aldaya, M. M. (2012) “A water footprint assessment of a pair of jeans: the influence of agricultural policies on the sustainability of consumer products". Journal of Cleaner Production 57: 238-248.

Statement of Authorship: Chico contributed to preparation of the data, method selection, interpretation and analysis of the data and led manuscript writing Aldaya contributed the analysis and manuscript writing, Garrido contributed to the analysis, goals and concept definition and manuscript writing.

\section{Chapter 5 (in submission):}

Chico, D., Pahlow, M., Willaarts, B., Sinisgalli, P, Garrido, A. (2017) "Economic and ecosystem services valuation of land \& water use in Brazilian sugarcane under evolving management practices and land use change".

Statement of Authorship: Chico contributed to preparation of the data, method selection, interpretation and analysis of the data and led manuscript writing, Pahlow contributed to the analysis, goals and scope definition and manuscript writing, Willaarts contributed to the analysis and manuscript writing, Sinisgalli contributed to the analysis and manuscript writing, Garrido, contributed to the analysis, goals and concept definition and manuscript writing.

\section{Other articles published in peer-reviewed joutnals}

De Stefano, L., Martínez-Santos, P., Villaroya, F., Chico, D., Martínez-Cortina, L., (2013) "Easier Said Than Done? The Establishment of Baseline Groundwater Conditions for the Implementation of the Water Framework Directive in Spain". WaterResources Management 27 (7).

Salmoral, G., Aldaya, M.M., Chico, D., Garrido, A., Llamas, M.R., (2011) “The water footprint of olives and olive oil in Spain" Spanish Journal of Agricultural Research no 9 (4).

\section{Other publications co-authored}

Chico, D.,Aldaya, M.M., Niemeyer, I., Garrido, A. (2014) "Virtual water trade, food security and sustainability: lessons from Latin America and Spain”. In: Martínez-Santos, 
CHAPTER 2. INCREASING EFFICIENCY IN ETHANOL PRODUCTION: WATER FOOTPRINT AND ECONOMIC PRODUCTIVITY OF SUGARCANE ETHANOL UNDER EIGHT IRRIGATION LEVELS IN NORTH-EASTERN BRAZIL

Aldaya, Llamas (eds.) Integrated Water Resources Management in the 21st Century: Revisiting the paradigm. Ed. Botín Foundation, Taylor \& Francis. Madrid

Chico, D; Garrido, A. (2012) “Overview of the extended water footprint in Spain”. In: De Stefano and Llamas (eds.). Water, Agriculture and the Environment: can we square the circle? Ed. Botín Foundation, Taylor \& Francis. Madrid

Aldaya, M. M. et al. (2014) "Water and agriculture" In: Willaarts, B., Garrido, A., Llamas, M.R. (eds.) Water for food Security and well-being in Latin America and the Caribbean. Ed. Botín Foundation, Earthscan. London.

Aldaya, M. M. et al. (2014) “Water efficiency: Status and trends” In: Willaarts, B., Garrido, A., Llamas, M.R. (eds.) Water for food Security and well-being in Latin America and the Caribbean. Ed. Botín Foundation, Earthscan. London.

De Stefano, L; Martínez-Cortina, L; Chico, D. (2012) “The relevant and almost ignored role groundwater in Spain's water policy”. In: De Stefano and Llamas (eds.). Water, Agriculture and the Environment: can we square the circle? Ed. Botín Foundation, Taylor \& Francis. Madrid

Salmoral, G; Chico, D. (2012). "Lessons learnt from the analyses of the tomato and olive oil water footprint in Spain” In: De Stefano and Llamas (eds.). Water, Agriculture and the Environment: can we square the circle? Ed. Botín Foundation, Taylor \& Francis. Madrid

Chico, D (2011) "Análisis de la huella hídrica y del comercio de agua virtual en España." Ms. Thesis Agricultural, Food and Natural Resource economics. Supervised by: Prof. Dr. Alberto Garrido. Defended July 7th 2011

Chico, D., Aldaya, M.M., Garrido, A., Llamas, M.R. Salmoral, G., (2010) “The water footprint and virtual water exports of Spanish tomatoes". Papeles de Agua Virtual no 8. Ed. Observatorio del Agua. Fundación Marcelino Botín. Madrid 


\section{INCREASING EFFICIENCY IN ETHANOL PRODUCTION: WATER FOOTPRINT AND ECONOMIC PRODUCTIVITY OF SUGARCANE ETHANOL UNDER EIGHT IRRIGATION LEVELS IN NORTH-EASTERN BRAZIL}

\subsection{Introduction}

The use of sugarcane ethanol in Brazil is one of the greatest examples of partial or total substitution of oil in the world. Liquid biofuels are the fastest growing sector of bioenergy. Besides reducing oil consumption, the production and use of sugarcane ethanol has competitive advantages in economic and environmental terms, compared both to nonrenewable fuels and renewable fuels from other crops. Their development has been the result of a interaction of policies, public and private institutions and partnerships that have created one of the most dynamic and competitive innovation systems in the world (Furtado et al., 2011). Brazilian ethanol production grew by 260 \% from 2001 to 2009, achieving 27,512 Hl in 2009 (São Paulo state sugarcane industry association, Unica, 2013).The United States has set objectives of biofuel usage for 136,274 million litres in 2022 (Environmental Protection Agency, EPA, 2007). Both US and European targets are above the current production capacity of each block, so they rely on internationally traded ethanol to meet them (FAO, 2013). Since Brazil is the world's second largest producer and first largest exporter, the country is in position to fill this gap and so global demand for Brazilian biofuel will continue to grow.

On the other hand, there are several works in the literature dealing with the possible negative effects of biofuel production. The main sources of bioethanol, corn and sugarcane, have implications on food security ${ }^{2}$ through its impact on commodity prices (FAO, 2008; FAO, 2013) and through direct or indirect land use change (Martinelli and Filoso, 2008; Meloni et al., 2008). Other major concern is the possible influence that large-scale biofuel development may

${ }^{2}$ G-20's declaration (2011), point 41, stated "We will continue to address the challenges and opportunities posed by biofuels, in view of the world's food security, energy and sustainable development needs. We recognize the need to further analyse all factors that influence the relationship between biofuels production and (i) food availability, (ii) response of agriculture to price increase and volatility, (iii) sustainability of agriculture production, and further analyse

potential policy responses, while recognizing the role biofuels can play in reduction of greenhouse gases, energy security and rural development". http://agriculture.gouv.fr/IMG/pdf/2011-06-23_-_Action_Plan__VFinale.pdf 
CHAPTER 3: INCREASING EFFICIENCY IN ETHANOL PRODUCTION: WATER FOOTPRINT AND ECONOMIC PRODUCTIVITY OF SUGARCANE ETHANOL UNDER EIGHT IRRIGATION LEVELS IN NORTH-EASTERN BRAZILINCREASING EFFICIENCY IN ETHANOL PRODUCTION: WATER FOOTPRINT AND ECONOMIC PRODUCTIVITY OF SUGARCANE ETHANOL UNDER EIGHT IRRIGATION LEVELS IN NORTH-EASTERN BRAZIL

have over the use of water (Gerbens-Leenes et al., 2009). To develop the potential of bioenergy, its development must be adapted to economic, environmental and social conditions, this last one being closely related to food security (FAO, 2008). Hoekstra and Chapagain (2007) estimated that the volume of water used in agricultural production worldwide is about 6,390 $\mathrm{Gm}^{3}$ year ${ }^{-1}$. The cultivation of sugarcane consumes $4 \%$ of the total water used in the world. Brazil leads the world's sugarcane production being also India, China, Thailand and Mexico important producers (FAO, 2013). Brazil produced 734 million tonnes in 2011, intended for the production of both sugar and ethanol. Commonly, mills are able to obtain both products and companies decide the amount of cane allocated to sugar or ethanol production based on the international sugar prices.

To meet the growing demand of ethanol and sugar, the area cultivated with sugarcane in Brazil increased from 4.82 million ha in 2000 to 9.6 million ha in 2011 (FAO, 2013). This increase was made possible by the incorporation of new areas that were previously dedicated to other agricultural activities, mainly pastures and crops like citrus, corn and beans (Meloni et al., 2008). The adoption of new technologies of production and processing has also played a relevant role on this expansion of sugarcane (Mello Ivo et al., 2008; Vasconcelos et al., 2008). The largest sugarcane producing region (shared among the states of São Paulo, Minas Gerais, Mato Grosso and Paraná, figure 2), traditionally produce sugarcane under rainfed conditions. In these regions, productivities average $80 \mathrm{t} \mathrm{ha}^{-1}$. Sugarcane is also rapidly expanding from these central areas west into Mato Grosso do Sul, and north further into Bahía, Goiás, and Maranhao states (Meloni et al., 2008). These areas have drier climates than São Paulo. 

FOOTPRINT AND ECONOMIC PRODUCTIVITY OF SUGARCANE ETHANOL UNDER EIGHT IRRIGATION LEVELS IN NORTH-EASTERN BRAZILINCREASING EFFICIENCY IN ETHANOL PRODUCTION: WATER FOOTPRINT AND ECONOMIC PRODUCTIVITY OF SUGARCANE ETHANOL UNDER EIGHT IRRIGATION LEVELS IN NORTH-EASTERN BRAZIL

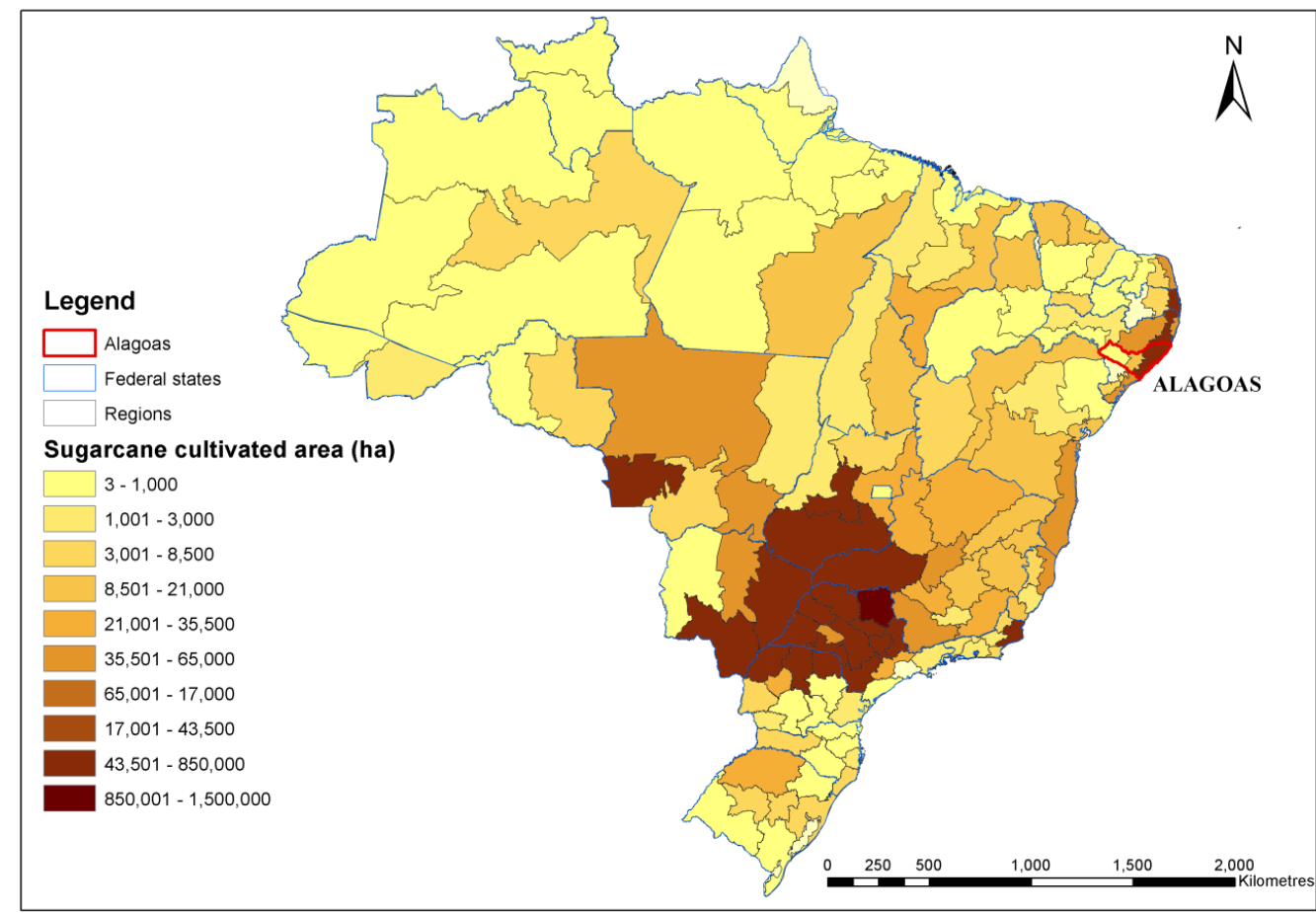

Figure 2.- Sugarcane cultivated are per micro-region. In red: Alagoas State. Source: IBGE (2013)

In the Northeast region (which contributes to $9 \%$ of the country's production), the state of Alagoas is the largest producer of sugar and alcohol, with a cultivated area of 430,000 ha. Most of the cultivated surface is rainfed, although irrigation is rapidly expanding. The most extended irrigation practice is to apply only supplemental irrigation in one or two applications. Nevertheless, sugarcane farmers have been investing heavily in technologies to increase production, notably through the adoption of new varieties and more frequent irrigation applications. There is a consensus among the producers of sugar and ethanol in the need for further investment in water storage infrastructures to increase the use of irrigation. This way greater productivities and increased longevity of sugarcane plantations could be achieved. At present, most mills combine various irrigation levels according to water availability at field level, field soil productivity, harvest organization and expected yield.

In the state of Alagoas, the irrigated area was 186,385 in 2007/2008 season and increased by $5.9 \%$ the following year. From this area, only $3.6 \%$ is fully irrigated. $62.5 \%$ of the area receives just one application, of $50-70 \mathrm{~mm}$, and $33.9 \%$ receives supplemental irrigation, that is, 
CHAPTER 3: INCREASING EFFICIENCY IN ETHANOL PRODUCTION: WATER FOOTPRINT AND ECONOMIC PRODUCTIVITY OF SUGARCANE ETHANOL UNDER EIGHT IRRIGATION LEVELS IN NORTH-EASTERN BRAZILINCREASING EFFICIENCY IN ETHANOL PRODUCTION: WATER FOOTPRINT AND ECONOMIC PRODUCTIVITY OF SUGARCANE ETHANOL UNDER EIGHT IRRIGATION LEVELS IN NORTH-EASTERN BRAZIL

2-3 irrigation events of 70-100 $\mathrm{mm}$. Vinasse is applied to 55,291 ha of the total irrigated area (Alagoas State sugar and alcohol Industry Union, Sindaçucar-AL, 2012).

Sugar and ethanol sector is one of the leading economic sectors in the Alagoas state, and has important implications at the social level, in the number of jobs provided, but also on their quality. The modernization from a labour intensive sector with a high number of low-skilled seasonal job demand to a more capital intensive sector demanding skilled technicians has very important implication for the local economy (Furtado et al., 2011). The development of the industry is related to capital access and policy support. These are likely to continue in the near future, reinforced by continuing flows of foreign direct investment. These factors will likely stimulate, at national level, sugarcane expansion, mill modernization and the development and implementation of co-generation technologies (ibid.), but also applies to mills in Alagoas state. At a regional level, these factors may also promote the intensification of the crop through irrigation and harvest mechanization.

In the industrial phase, the range of water consumption in this sector is wide. Buarque et al. (2003) studied the water consumption of 10 sugar-ethanol mills in the state of Alagoas and found that 0.7 to $12.2 \mathrm{~m}^{3}$ per ton of cane processed were needed. Several factors influence this consumption, among others, the age of the plant, proximity to water sources, and use of energy generation technologies. Nevertheless, water consumption by the industrial production of sugarcane has been declining rapidly during the last four decades Brazilian National Environmental Agency (ANA, 2009), mainly because of environmental laws, as well as technological improvement in the machinery and the imminent implantation of a system to charge for water use. Water requirements ranging from 15 to $20 \mathrm{~m}^{3} \mathrm{t}^{-1}$ of cane in the $1970 \mathrm{~s}$ decreased to $5.6 \mathrm{~m}^{3}$ in the $1990 \mathrm{~s}$, and for new units in São Paulo being implemented at present, consumption cannot be greater than $1 \mathrm{~m}^{3} \mathrm{t}^{-1}$ following state regulation (ibid.).

In addition to water consumption, sugarcane plants also potentially impact water quality through effluent generation. The main effluent of ethanol production is vinasse. Vinasse is a by-product of ethanol production generated in large quantities rich in potassium, nitrate. magnesium and organic matter. Its disposal is a potential environmental problem, due to its high organic and nutrient load (Gunkel et al., 2007). To avoid its direct discharge in water bodies, the Brazilian sugarcane agro-industry has used fertigation for years by applying vinasse 
CHAPTER 3: INCREASING EFFICIENCY IN ETHANOL PRODUCTION: WATER FOOTPRINT AND ECONOMIC PRODUCTIVITY OF SUGARCANE ETHANOL UNDER EIGHT IRRIGATION LEVELS IN NORTH-EASTERN BRAZILINCREASING EFFICIENCY IN ETHANOL PRODUCTION: WATER FOOTPRINT AND ECONOMIC PRODUCTIVITY OF SUGARCANE ETHANOL UNDER EIGHT IRRIGATION LEVELS IN NORTH-EASTERN BRAZIL

on sugarcane plantations and the agronomic and economic advantages of its use are now widely recognized.

Still, the full environmental consequences of vinasse use have not been clearly established. The existence and actual rates of leaching nitrogen from fertilizing under various soils and management practices (concerning dilution with irrigation water, type and amount of fertilizer, number and rate of vinasse applications and their interactions) are not clearly identified in the literature (Oliveira et al. 2002; Silva et al., 2007, Ghiberto et al., 2009, 2011). The studies also offer mixed results on the lixiviation of vinasse and agrochemicals (Oliveira et al., 2002, Silva et al., 2007, Davis et al., 2013). Differences between the studies in application rates, soil and timing may explain these mixed results.

Gunkel et al. (2007) measured the negative effects of vinasse use in freshwater related to direct river discharge and high-level irrigation use, affecting $\mathrm{BOD}_{5} \mathrm{pH}$ and dissolved oxygen Nevertheless, Silva et al. (2007), Leme et al. (1987) and Camargo et al. (1983) mention the limited impacts of vinasse use in the form of nitrate leaching. Vinasse use in moderate levels, taking into account the soil's nutrient balance, is recognized as an environmentally friendlier agricultural technique (Gunkel et al., 2009). Vinasse application also improves the productivity and longevity of sugarcane plantations, bringing economic benefits and avoiding further fertilizer, herbicide and water use. With the current use of vinasse, contamination of water bodies is avoided and the potassium plant needs are met, increasing the number of ratoons (Pires et al., 2008).

Nevertheless, there may still be a need for detailed study on the amount, rate and timing of vinasse applications, especially with a long-term perspective and taking into account the large areas covered by sugarcane in some river basins. Although the state of São Paulo implemented regulations limiting the amount applied per ha and forcing users to introduce measures to avoid leaching from channels and deposits, in Alagoas there is no state regulation on the subject. However, it is valued by producers as a cost-saving fertilizing technique and thus used in fertigation.

One of the tools available to quantify the amount of water used in the production of a particular product is the water footprint (WF). The WF is a methodology to account for the direct and indirect water consumption linked to a particular activity, spatially and temporally 
CHAPTER 3: INCREASING EFFICIENCY IN ETHANOL PRODUCTION: WATER FOOTPRINT AND ECONOMIC PRODUCTIVITY OF SUGARCANE ETHANOL UNDER EIGHT IRRIGATION LEVELS IN NORTH-EASTERN BRAZILINCREASING EFFICIENCY IN ETHANOL PRODUCTION: WATER FOOTPRINT AND ECONOMIC PRODUCTIVITY OF SUGARCANE ETHANOL UNDER EIGHT IRRIGATION LEVELS IN NORTH-EASTERN BRAZIL

explicit (Hoekstra et al., 2011). The WF tool is a useful way to empirically evaluate the overall chain of production stages that contributes to water consumption (Hughes et al. 2007). Estimations can be used for decision-making regarding the amount of water consumed in the entire production chain of the product studied. When evaluated as litres consumed per unit produced, the WF is also a measure of water productivity. In any case, WF accounting is a measure of the pressure that an activity makes over water resources. To be more insightful, an adequate contextualization of the area under study and water use within a basin is needed. The present article is intended as a detailed accounting of the WF of current irrigation practices in the region, which would need further framing of the social and environmental implications of this development. The objective of this study was to quantify the WF of ethanol production in the state of Alagoas, Brazil, under eight irrigation levels and rainfed production over three seasons (2009, 2010 and 2011) using the methodology proposed by Hoekstra et al. (2011). An analysis of the economic productivity of water, estimated as the apparent water productivity at farm level was carried out to complete the analysis. It enabled us to evaluate the water consumption and productivity by current practices in the region and support considerations over possible future developments of irrigation in the region.

\subsection{Materials and methods}

\subsubsection{Characterization of the region}

This study was based on field data from Seresta sugarcane mill, located in the city of TeotonioVilela in the state of Alagoas, Brazil. The cultivated area is located in the region known as the Coastal Plains, which features flat terrain and low fertility. Both the mill and the land are representative of the region's plantations.

The region has a tropical rainy climate with dry summers (CPRM, 2005) and an average precipitation of $1,634 \mathrm{~mm}$, which is concentrated in the months from May to July. Podzolic soil types dominate, with Fregipan, Podzols and PodzolicPlintic soils in small depressions. An important characteristic of these soils is the presence of cohesive layers located between 75 to $150 \mathrm{~cm}$ deep that prevent a perfect deepening of roots (Jacomine, 2001). In Alagoas, average rainfed productivities are $60 \mathrm{t} \mathrm{ha}^{-1}$, due to a marked dry season in the months from September to February. 
CHAPTER 3: INCREASING EFFICIENCY IN ETHANOL PRODUCTION: WATER FOOTPRINT AND ECONOMIC PRODUCTIVITY OF SUGARCANE ETHANOL UNDER EIGHT IRRIGATION LEVELS IN NORTH-EASTERN BRAZILINCREASING EFFICIENCY IN ETHANOL PRODUCTION: WATER FOOTPRINT AND ECONOMIC PRODUCTIVITY OF SUGARCANE ETHANOL UNDER EIGHT IRRIGATION LEVELS IN NORTH-EASTERN BRAZIL

\subsubsection{Characterization of the Production Systems}

In line with the general trend in the North-east, the studied company dedicates significant areas to different irrigation regimes. The production system of the sugarcane mill studied is the common form of the North-east region, where sugarcane is harvested has after between 10 and 14 months of development. The period of grinding in the mill runs from the second half of August to March. This work considered a growing period of 365 days starting on November $1^{\text {st }}$ and ending on October $31^{\text {st }}$ of the following year.

In the 2009, 2010 and 2011 agricultural seasons, the company cultivated around 11,000 ha using nine water levels which ranged from no irrigation to $552 \mathrm{~mm}$ in plots that varied in area from 204 to 1,550 hectares. The data were used as a base for the calculation of the water consumption and refer to real information provided by the mill technicians (Table 1). These data included planting and harvesting dates, irrigation depth and irrigation frequency, the fertilizer rates and amount of vinasse applied in the areas that received fertigation. Sugarcane productivity for each irrigation level was used for the quantification of crop WF.

The eight different irrigation levels were applied using three irrigation systems: Pivot, irrigation gun and drip irrigation. For all irrigation levels, approximately half of the area received mineral fertilization while the other half was fertigation with vinasse diluted in water. Full irrigation to satisfy crop water needs $(552 \mathrm{~mm})$ was carried out with a sub-surface drip. The applied depths ranged from $50 \mathrm{~mm}$ to $350 \mathrm{~mm}$ spaced every 30 days from the harvest date of the previous year, increasing an irrigation event by $50 \mathrm{~mm}$ for each of them. Sprinkler irrigation was carried out with a mobile irrigation gun for lower irrigation levels, between 50 and 150 $\mathrm{mm}$. Irrigation levels between 200 to $350 \mathrm{~mm}$ were applied with an auto-towable pivot. The complex logistics of irrigation in the mill prevents the application of smaller, more frequent irrigation events, which would reduce the loss of water from irrigation runoff and percolation. There is a tendency in the sugar mills to use auto-pivot for higher irrigation levels because of its lowest labour requirements and consequently lower costs. Full irrigation by drippers provided $9 \mathrm{~mm}$ whenever the soil presented the need for water supplementation, which was estimated based on the experience of the technicians at the mill, approximately every 2 to 3 days. 
CHAPTER 3: INCREASING EFFICIENCY IN ETHANOL PRODUCTION: WATER FOOTPRINT AND ECONOMIC PRODUCTIVITY OF SUGARCANE ETHANOL UNDER EIGHT IRRIGATION LEVELS IN NORTH-EASTERN BRAZILINCREASING EFFICIENCY IN ETHANOL PRODUCTION: WATER FOOTPRINT AND ECONOMIC PRODUCTIVITY OF SUGARCANE ETHANOL UNDER EIGHT IRRIGATION LEVELS IN NORTH-EASTERN BRAZIL

Table 1.- Description of treatments, numbers and methods of irrigation, cultivated area (ha) and average productivity $\left(t \mathrm{t}^{-1}\right)$

\begin{tabular}{|c|c|c|c|c|c|c|c|c|c|c|c|}
\hline \multirow{2}{*}{$\begin{array}{l}\text { Irrigation } \\
\text { level }\end{array}$} & \multirow{2}{*}{$\begin{array}{l}\text { Number } \\
\text { of } \\
\text { irrigation } \\
\text { events }\end{array}$} & \multirow{2}{*}{$\begin{array}{l}\text { Irrigation } \\
\text { methods }\end{array}$} & \multicolumn{3}{|c|}{ Nitrogen fertilization $\left(\mathrm{kgN} \mathrm{ha}{ }^{-1}\right)$} & \multicolumn{3}{|c|}{ Area (ha) } & \multicolumn{3}{|c|}{ Productivity (t ha -1 ) } \\
\hline & & & $\begin{array}{l}\text { Plant } \\
\text { Cane }\end{array}$ & $\begin{array}{l}\text { Ratoon cane } \\
\text { without vinasse }\end{array}$ & $\begin{array}{l}\text { Ratoon cane } \\
\text { with vinasse }\end{array}$ & 2009 & 2010 & 2011 & 2009 & 2010 & 2011 \\
\hline Rain-fed & - & - & 48 & 77 & 65 & 2,213 & 2,550 & 2,513 & 52.43 & 49.56 & 56.37 \\
\hline 50 & 1 & $\begin{array}{l}\text { irrigation } \\
\text { gun }\end{array}$ & 48 & 77 & 65 & 2,508 & 2,509 & 2,319 & 57.25 & 52.27 & 61.86 \\
\hline 100 & 2 & $\begin{array}{l}\text { irrigation } \\
\text { gun }\end{array}$ & 48 & 77 & 65 & 1,244 & 1,538 & 1,700 & 64.61 & 57.25 & 63.51 \\
\hline 150 & 3 & $\begin{array}{l}\text { irrigation } \\
\text { gun }\end{array}$ & 48 & 77 & 65 & 1,050 & 1,019 & 1,278 & 67.28 & 60.09 & 64.31 \\
\hline 200 & 4 & Pivot & 48 & 77 & 65 & 829 & 849 & 892 & 70.25 & 65.19 & 68.17 \\
\hline 250 & 5 & Pivot & 48 & 77 & 65 & 548 & 514 & 437 & 73.17 & 67.30 & 71.14 \\
\hline 300 & 6 & Pivot & 48 & 77 & 65 & 280 & 204 & 209 & 76.46 & 69.74 & 76.55 \\
\hline 350 & 7 & Pivot & 48 & 77 & 65 & 467 & 381 & 274 & 76.77 & 73.03 & 78.32 \\
\hline $\begin{array}{l}\text { Full } \\
(552 \mathrm{~mm})\end{array}$ & $107-127$ & Drip & 48 & 110 & 92.86 & 1,481 & 1,481 & 1,464 & 96.41 & 103.43 & 96.83 \\
\hline
\end{tabular}

Source: Own elaboration based on information from the mill. 
Commercial formula containing the three macroelements, N, P, K, and micronutrients were used for fertilising according to the crop needs. There was variation depending on whether vinasse was used. The area not irrigated with vinasse, approximately half of the area irrigated in each irrigation level, received $77 \mathrm{~kg} \mathrm{ha}^{-1}$ of nitrogen. When applied, vinasse was diluted with irrigation water to a level of $7 \%$ and applied to $23 \%$ of the total area of the mill. In this area, the demand of potassium was met, and only needed receiving an additional 65 $\mathrm{kg} \mathrm{ha}^{-1}$ of nitrogen. Fertilising was done in one event in topdressing immediately before planting the new sugarcane or after harvesting previous ratoon.

\subsubsection{Water footprint calculation}

The WF calculation was based on the methodology developed by Hoekstra et al. (2011). As an indicator it includes three dimensions (colours) of water use (green, blue and grey). Green water is defined as the amount of precipitation that is stored in the soil and consumed during plant growth and evaporation. Blue water is extracted from the water surface and groundwater bodies and used for irrigation or in industrial processes. Grey water is defined as the water required to dilute the pollutants resulting from productive processes, being an indicator of water quality degradation (Hoekstra et al., 2011). This distinction builds on the different implications that each water colour has on the water hydrological cycle. While green water is linked to land use and the opportunity cost of land, blue water is usually related to resource scarcity and allocation. Grey WF, which does not reflect actual water consumption, is an indicator of the pressure over the water quality of the receiving water body. In our case, the application of the methodology involved the estimation of the WF of sugarcane production under each irrigation level, vinasse use and studied year, and the WF of the industrial phase. This way, we could estimate the WF of ethanol production, in litres of water per litre of ethanol produced.

For the quantification of blue and green water for each irrigation level we used the program Cropwat 8.0 (FAO, 2009). The program performs a soil water balance to calculate the crop evapotranspiration as a function of soil water availability. Local data on monthly potential evapotranspiration (ETo), precipitation and soil type were provided by the mill. Irrigation data provided by the mill was fed into the program to estimate the fraction of evapotranspiration consumed from soil or irrigation water, thus obtaining the green and blue water consumption, respectively. In treatments that received irrigation, blue water consumption was calculated by subtracting the irrigation losses from the total net irrigation. Irrigation efficiency (including technical efficiency and scheduling efficiency) averaged 65\% 
CHAPTER 3: INCREASING EFFICIENCY IN ETHANOL PRODUCTION: WATER FOOTPRINT AND ECONOMIC PRODUCTIVITY OF SUGARCANE ETHANOL UNDER EIGHT IRRIGATION LEVELS IN NORTH-EASTERN BRAZILTHE WATER FOOTPRINT ASSESSMENT OF A PAIR OF JEANS: INFLUENCE OF AGRICULTURAL PRODUCTION IN CONSUMER PRODUCT'S SUSTAINABILITY for all irrigation levels and years, and a standard deviation of 3.5\%. Green water was estimated as the difference between crop evapotranspiration (actual water use by crop) and blue water. Crop water consumption was divided by the productivity for each irrigation level to obtain the green and blue WF per irrigation level and year.

Grey WF of the sugarcane cultivation was estimated based on the nitrogen leaching. Lacking clear results in the literature, leaching of nitrogen from fertilizing was estimated as $10 \%$ of the amount applied following the general recommendation by Hoekstra et al. (2011). In addition to fertilizing, vinasse application is another potential source of nitrogen lixiviation. The losses of nitrogen contained in the vinasse $\left(356 \mathrm{mgN} \mathrm{l}^{-1}\right)$ were added to this amount. As fertilization occurs during the dry season in the time between ratoons, no leaching losses were considered in rainfed areas. The estimated amount of nitrate leached was divided by the legal standard for nitrogen. The relevant standard at the federal level was taken, $10 \mathrm{mg} \mathrm{NO}_{3}^{-} \mathrm{I}^{-1}$, to obtain the nitrogen polluting load (Brazil, 2005). This estimated load was divided by the crop productivity in $\mathrm{t} \mathrm{ha}^{-1}$ per irrigation method and year resulting in the grey WF of the sugarcane.

In relation to water consumption in the industry for ethanol production, the ANA (2011) estimates that the reuse of water in the various circuits should be considered in the average use of water in processing ethanol, with or without treatment. In the state of Alagoas, although water use levels are being reduced, values are estimated in the range of $5.6 \mathrm{~m}^{3} \mathrm{t}^{-1}$ cane. It is estimated that $1.8 \mathrm{~m}^{3} \mathrm{t}^{-1}$ is lost from this amount by evaporation (ibid.). Therefore, the value considered in this work as blue water consumption in the industrial phase was 1.8 $\mathrm{m}^{3} \mathrm{t}^{-1}$.

Most mills in Alagoas have also been going through processes to improve the efficiency in terms of water usage. This is reflected in the reuse for irrigation of the water used for washing the sugarcane stalks at the facility reception and the water effluents from the mill. Stalks washing is the most water intensive process of the industrial phase. In this study, the use of wash water for irrigation was not considered as a consumption of the industrial phase but as part of the water used in irrigation. In addition to this, since all water effluents from the mill are diluted with vinasses and irrigation water, no grey WF of the industrial phase was estimated. 
FOOTPRINT AND ECONOMIC PRODUCTIVITY OF SUGARCANE ETHANOL UNDER EIGHT IRRIGATION LEVELS IN NORTH-EASTERN BRAZILTHE WATER FOOTPRINT ASSESSMENT OF A PAIR OF JEANS: INFLUENCE OF AGRICULTURAL PRODUCTION IN CONSUMER PRODUCT'S SUSTAINABILITY

Aside from ethanol, sugarcane bagasse and vinasses were evaluated, the main subproducts of ethanol production. Bagasse is the solid waste resulting from stalk grinding, which is burned for co-generation of heat and electricity. This is a way of allocating water consumption in the production of sugarcane into its different products. The concepts of product fraction (pf) and value fraction ( $\mathrm{vf}$ ) were used according to the WF methodology (equation 1, from Hoekstra et al. 2011). Product fraction is defined as the quantity of (sub-) product obtained, in mass, per unit of primary product, in mass. In this case, the amount of ethanol, bagasse or vinasse obtained per tonne of sugarcane. The value fraction is defined as the ratio of the market value of (sub-) product to the aggregated market value of all products and sub-products obtained.

$$
W F_{\text {sub-product }}=\left(W F_{\text {primarypraluct }}\right) \times \frac{P_{\text {primarypraluct }}}{P_{\text {sub-product }}} \times \frac{v_{\text {sub-product }} \times p f_{\text {sub-product }}}{\sum_{\text {all_sub-products }}\left(v_{\text {sub-products }} \times p f_{\text {sub-products }}\right)}<
$$

[Eq. 1]

In which:

$\mathrm{WF}_{\text {sub product }}=$ the $\mathrm{WF}$ of the sub product taken into consideration (vinasse or bagasse, 1 $\mathrm{l}^{-1}$ or $\left.1 \mathrm{~kg}^{-1}\right)$

$\mathrm{WF}_{\text {primary product }}=$ the $\mathrm{WF}$ of the primary product that derives in several sub products (sugar cane, $1 \mathrm{~kg}^{-1}$ )

$\mathrm{P}_{\text {primary product }}=$ Weight of the primary product $(\mathrm{kg})$

$\mathrm{P}_{\text {sub product }}=$ Weight of the specific sub product taken into consideration $(\mathrm{kg})$

$\mathrm{Pf}_{\text {sub product }}=$ Product fraction of the specific sub product taken into consideration

$\mathrm{V}_{\text {sub product }}=$ Economic value of the specific sub-product taken into consideration (US\$)

These concepts allow for recognizing the relevance of sub-products with an economic value in reducing the pressure over water resources of a particular production. Additionally, their use avoids the need of their safe disposal and prevents this way potential environmental 
CHAPTER 3: INCREASING EFFICIENCY IN ETHANOL PRODUCTION: WATER FOOTPRINT AND ECONOMIC PRODUCTIVITY OF SUGARCANE ETHANOL UNDER EIGHT IRRIGATION LEVELS IN NORTH-EASTERN BRAZILTHE WATER FOOTPRINT ASSESSMENT OF A PAIR OF JEANS: INFLUENCE OF AGRICULTURAL PRODUCTION IN CONSUMER PRODUCT'S SUSTAINABILITY harms (Silva et al., 2007). The results obtained by current practices of the sector are better reflected this way, as ascribing the total sugarcane production to ethanol production.

In the literature, several papers have reported the amount of vinasse generated in ethanol production, with values varying from 10 to 16 litres of vinasse per litre of ethanol produced. This work has established a relationship of 12 litres of vinasse for 1 litre ethanol. In order to assign an economic value to the vinasse, the price of the potassium chloride was used, which is no longer applied when the vinasse is used (Almeida et al., 2007).

In Brazil, sugar and ethanol mills are self-sufficient in terms of energy, because the bagasse is used as a source of energy co-generation. Several industries in the sector are undergoing a modernisation process of their boilers and factories and aiming to increase the amount of electricity generated and the efficiency of heat use. The net excess electricity between the plant's energy generation and consumption is sold to utility companies for general use. A mill that is not modernised generates around $14 \mathrm{kWh}$ per tonne of cane processed (Bajay and Ferreira, 2005). Of these, $85 \%$ is used in the industrial unit and the remaining $15 \%$ can be negotiated with the power companies. These were the values used in this study for the estimation of the value of bagasse. Prices per MWh were obtained from the Electricity chamber of commerce (CCEE, 2013).

\subsubsection{Economic evaluation of water footprint results}

The study completed bioethanol's WF study under different irrigation levels in economic terms by including an analysis of the profits and water economic productivity. For the calculation of the crop's economic benefits $\left(\mathrm{US} \$ \mathrm{ha}^{-1}\right.$ ), an estimation of the revenues and costs of production was carried out. By dividing them by the WF, the water apparent productivity (WAP, in US $\$ \mathrm{~m}^{-3}$ ) was obtained.

Total variable costs were calculated as the costs associated with irrigation, sowing, crop management and harvesting costs per ha, including associated labour, energy and transport costs. The costs of irrigation were obtained from the mill technicians, but the investments costs of system's installations were not taken into account in this work. The objective was to study the variable costs associated with production, since they determine the decision making in the mill, and production decisions in the short term. There is no water price in the state of Alagoas. However, each company is responsible for building, maintaining and managing 
CHAPTER 3: INCREASING EFFICIENCY IN ETHANOL PRODUCTION: WATER FOOTPRINT AND ECONOMIC PRODUCTIVITY OF SUGARCANE ETHANOL UNDER EIGHT IRRIGATION LEVELS IN NORTH-EASTERN BRAZILTHE WATER FOOTPRINT ASSESSMENT OF A PAIR OF JEANS: INFLUENCE OF AGRICULTURAL PRODUCTION IN CONSUMER PRODUCT'S SUSTAINABILITY the water infrastructure, including the river dam, water conveyance and distribution to the fields. In this case, separate costs were available for the analysis of irrigation with auto-pivot or sprinkler irrigation with an irrigation gun as estimated by the mill, including electricity costs, transport, labour and associated taxes (table 2).

Table 2.- Irrigation costs per ha and per mm, per irrigation system. Average of three years

\begin{tabular}{lllll} 
& Rain-fed & $\begin{array}{c}\text { Irrigation } \\
\text { gun }\end{array}$ & Auto-Pivot & Drip \\
\hline $\begin{array}{l}\text { Average variable costs } \\
\left(\mathrm{US} \$ \mathrm{ha}^{-1} \text { ) }\right.\end{array}$ & 1,232 & 1,488 & 1,629 & 2,182 \\
$\begin{array}{l}\text { Average variable costs } \\
\left(\mathrm{US} \$ \text { applied } \mathrm{mm}^{-1} \text { ) }\right.\end{array}$ & 0 & 11.6 & 10.6 & 2.2 \\
\hline
\end{tabular}

Source: Own elaboration based on information from the mill

Drip irrigation has the lowest cost, and the irrigation gun method is the most expensive. However, in drip irrigation, installation costs are significantly higher, and so are crop management and harvest costs because of the significant increase in productivity. The installation of underground drips was not included in the calculations, as it was considered a fixed cost.

The revenue included the valuation of the sub-products together with ethanol production. Ethanol production per ha was multiplied by its average yearly price. The prices were based in the data collected by CEPEA (2011), for the ethanol market in Alagoas. The average of the three years of this study was US $\$ 0.55$ per litre. Bagasse production and vinasse application were evaluated by the electricity generated and potassium chloride that they respectively substitute.

Water apparent productivity was obtained by dividing the total profit by the estimated WF, including blue, green and grey water. This way, an estimation of the economic efficiency of water consumption was obtained, including the valuation of green water. 
CHAPTER 3: INCREASING EFFICIENCY IN ETHANOL PRODUCTION: WATER FOOTPRINT AND ECONOMIC PRODUCTIVITY OF SUGARCANE ETHANOL UNDER EIGHT IRRIGATION LEVELS IN NORTH-EASTERN BRAZILTHE WATER FOOTPRINT ASSESSMENT OF A PAIR OF JEANS: INFLUENCE OF AGRICULTURAL PRODUCTION IN CONSUMER PRODUCT'S SUSTAINABILITY

An approximate evaluation of the gross margin was obtained with the methods and sources mentioned above. In view of the limited reliable data, the economic results should be taken with caution and be considered as merely indicative. First, the price of ethanol is volatile, as they are also the prices of some other inputs including fertilizers and outputs, such as electricity. Secondly, no fixed costs are included. This implies that the calculations are not providing any indication about the profitability of a new factory, but rather how profitable a mill already under operation could be, and what would be the productivity of the product. Thirdly, the opportunity cost of water is assumed null, but eventually there might be an application of water tariffs that may change the results of the study. Lastly, the production costs are always more variable than what are assumed in this study.

\subsection{Results}

\subsubsection{Ethanol water footprint results}

In the case of ethanol production, it was observed that the larger the water supply through irrigation, the lower the green WF and the greater the blue WF per unit (litre of water per litre of ethanol produced), (Figure 3). On the other hand, grey WF decreased with increasing irrigation levels, with the exception of full irrigation. This result is explained by the increased yield of sugarcane stalks per unit area combined with the increased amount of nitrogen fertilisers used in the drip irrigation system.

Of all the irrigation levels evaluated, the one which had the highest value of WF received only one irrigation event $(50 \mathrm{~mm})$, resulting in ethanol's WF of 2,197 $11^{-1}(1,500 ; 55$ and 642 for green, blue and grey water, respectively), with a significant grey WF component (Figure 3). With low and intermediate irrigation levels, 50 to $250 \mathrm{~mm}$ of water applied, the average total WF was greater than the average total WF of rainfed production. In areas that received high irrigation levels, 300 and $350 \mathrm{~mm}$, the WF was between 1,959 and 2,585 $11^{-1}$. 
FOOTPRINT AND ECONOMIC PRODUCTIVITY OF SUGARCANE ETHANOL UNDER EIGHT IRRIGATION LEVELS IN NORTH-EASTERN BRAZILTHE WATER FOOTPRINT ASSESSMENT OF A PAIR OF JEANS: INFLUENCE OF AGRICULTURAL PRODUCTION IN CONSUMER PRODUCT'S SUSTAINABILITY

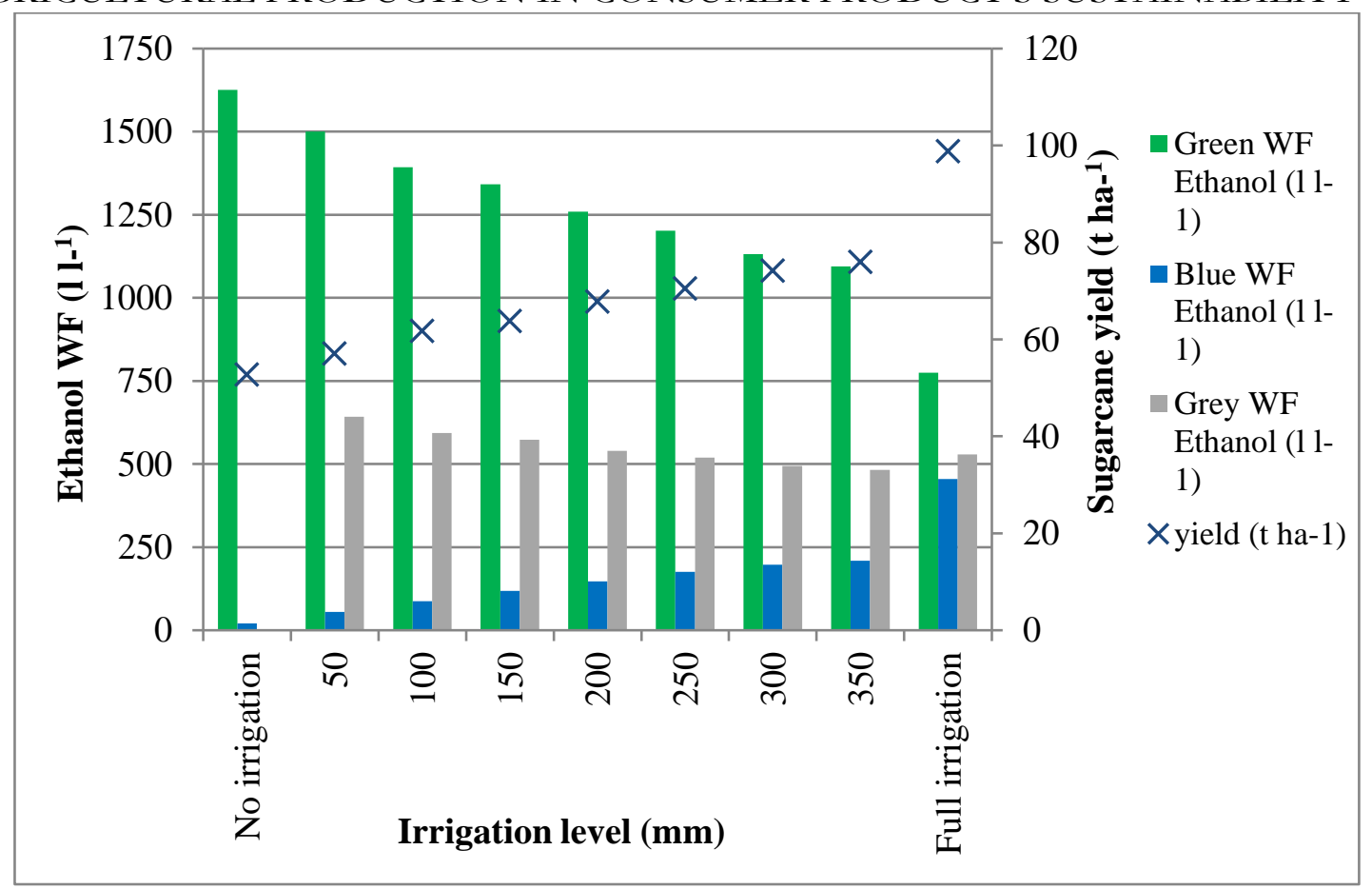

Figure 3.- Green, blue and grey WF of ethanol $\left(11^{-1}\right.$, left axis) and obtained yield (right axis) per irrigation level. Average 2009, 2010 and 2011

As relevant as the total WF is the relation between the different components of the WF. As the applied water increased, green water was found to represent a smaller share of the WF, and the blue WF increased its share. Grey WF also increased with irrigation even when it increased less than the blue WF. The lowest total WF was observed in the rainfed area, whose value was 1,647 $11^{-1}$ of ethanol, followed by areas that received full irrigation with $1,7581^{-1}$. However, total differences rely heavily on the result of the grey WF, which includes important uncertainties. These uncertainties are related not only to nitrogen leaching but also to potential environmental and health harms from pesticide use. Management practices allow for a reduction in nitrogen leaching (Oliveira et al., 2002) and precipitation and irrigationdriven pesticide runoff in dry-tropical climates (Davis et al., 2013).

Comparing water consumption in the agricultural and industrial sectors, it was found that the volume of water consumed in the operations of the industry is small, $22.511^{-1}$, representing only $1.1 \%$ of the total. The use of water in the plant is estimated at 70 litres of water per litre of ethanol produced, of which 22.5 litres of water per litre of ethanol is consumed. The rest of the water is collected and mixed with vinasses and then diluted with 
CHAPTER 3: INCREASING EFFICIENCY IN ETHANOL PRODUCTION: WATER FOOTPRINT AND ECONOMIC PRODUCTIVITY OF SUGARCANE ETHANOL UNDER EIGHT IRRIGATION LEVELS IN NORTH-EASTERN BRAZILTHE WATER FOOTPRINT ASSESSMENT OF A PAIR OF JEANS: INFLUENCE OF AGRICULTURAL PRODUCTION IN CONSUMER PRODUCT'S SUSTAINABILITY irrigation water. This supports the idea that the concerns about the impacts of ethanol production on water resources should primarily be focused on the crop production phase. In past decades, important efforts and investments have succeeded in bringing down mills' water use and consumption, as well as effluent reuse and treatment (Martinelli and Filoso, 2008). However, this study suggests that the water consumption and potential pollution lies in the crop production phase. In this respect, the North-eastern production differs from the rest of the country where sugarcane is still mostly rainfed.

As part of our work, we also compared the effect on the ethanol WF for the use of vinasse. In terms of WF of sugarcane, the cultivation without vinasse had a slightly higher WF due to a higher grey WF (Figure 4) from higher fertilizer application. This way, the use of vinasse as fertigation, as it was modelled in this work, would pose lower pressure on water resources quality since it reduces fertilizer applied and shows lower potential lixiviation. Through the use of vinasse, nitrogen application is fractioned, so the potential for lixiviation is potentially reduced. As for the lixiviation of the vinasse itself, it is linked to the irrigation efficiency. However, its dilution with irrigation water and the resulting low nitrogen content lowers potential risks.

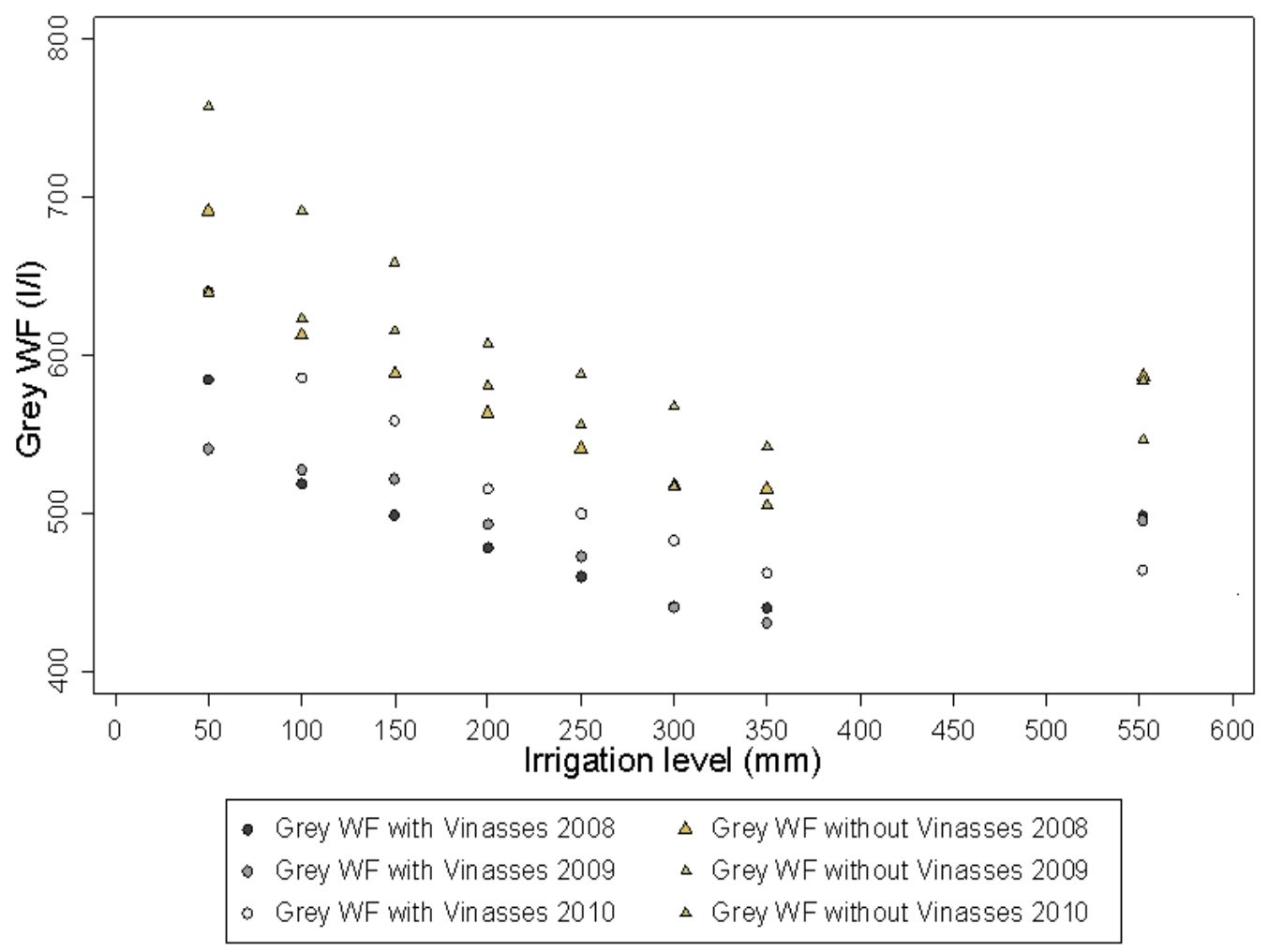


CHAPTER 3: INCREASING EFFICIENCY IN ETHANOL PRODUCTION: WATER FOOTPRINT AND ECONOMIC PRODUCTIVITY OF SUGARCANE ETHANOL UNDER EIGHT IRRIGATION LEVELS IN NORTH-EASTERN BRAZILTHE WATER FOOTPRINT ASSESSMENT OF A PAIR OF JEANS: INFLUENCE OF AGRICULTURAL PRODUCTION IN CONSUMER PRODUCT'S SUSTAINABILITY Figure 4.- Grey WF $\left(1^{-1}\right)$ per irrigation depth, year and vinasse use

Even though vinasse substitutes a certain volume of irrigation water, vinasse originally comes from water used in the industrial phase (for washing the cane stalks, and vegetation water from the plant's cells), which in turn was obtained from surface water bodies. Therefore, the applied vinasse was considered blue water and the final result in litres of water per ethanol litre is the same. In this way, the use of vinasse would relocate blue WF from the agricultural to the industrial phase, affecting only at a local level the water resources.

\subsubsection{Water economic productivity of ethanol production}

An analysis of irrigation costs and revenues obtained from the sugarcane products provided estimates of the economic benefits and the water economic productivity of sugarcane. The economic benefits of the different irrigation systems were estimated as the difference between the obtained revenues per ha, and the estimated total variable costs per ha. In the case of revenues, since they are a direct function of yield, rainfed production provides the lowest returns, including those coming from sub-products use. Areas with drip irrigation showed the highest revenues of 4,429 US\$ ha ${ }^{-1}$ as an average of the three years, which run much higher than 2,735 US\$ ha ${ }^{-1}$ with irrigation gun, 3,237 US\$ ha-1 with AutoPivot and the 2,371 US $\$ h^{-1}$ under rainfed conditions. Drip irrigation fully satisfied plant water needs and obtained significantly higher yields, while using larger amounts of water.

Mainly as a function of the increase in stalk productivity and consequently ethanol, vinasse and energy co-generation, the drip irrigation system provided the greatest economic benefits and water economic productivity, followed by irrigation levels of 300 and $350 \mathrm{~mm}$ (figure 5). The application of only $50 \mathrm{~mm}$ provided the lowest benefits when comparing the treatments that received supplemental irrigation $\left(1,235 \mathrm{US} \$ \mathrm{ha}^{-1}\right)$. It can be seen that drip irrigation (irrigation with $552 \mathrm{~mm}$ ) shows the highest water apparent productivity, whereas 50, 100 and $150 \mathrm{~mm}$ irrigation levels have in average similar productivities as rainfed irrigation (Figure 5). 

FOOTPRINT AND ECONOMIC PRODUCTIVITY OF SUGARCANE ETHANOL UNDER EIGHT IRRIGATION LEVELS IN NORTH-EASTERN BRAZILTHE WATER FOOTPRINT ASSESSMENT OF A PAIR OF JEANS: INFLUENCE OF AGRICULTURAL PRODUCTION IN CONSUMER PRODUCT'S SUSTAINABILITY

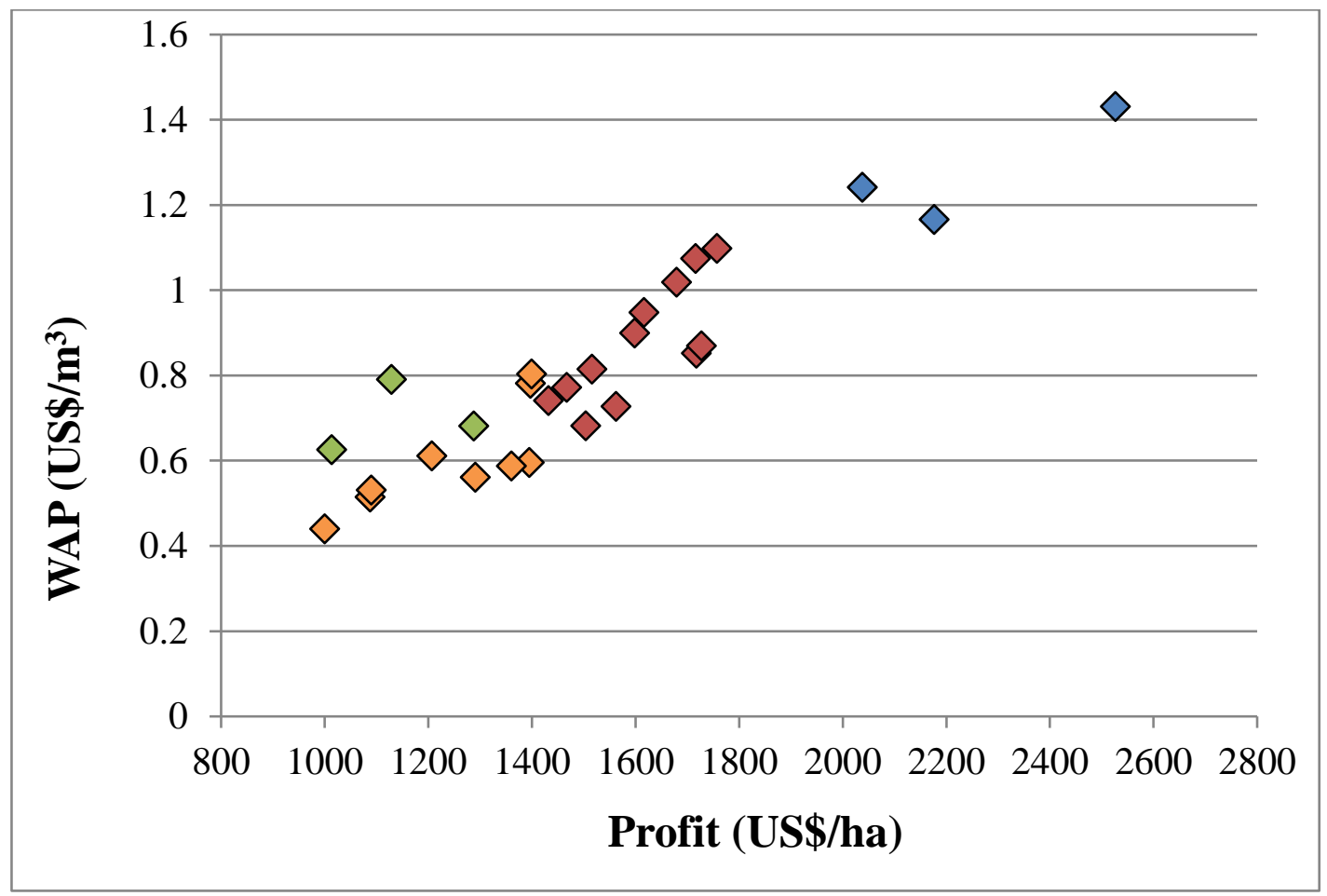

Figure 5.- Total Profit (US $\$ \mathrm{ha}^{-1}$ ) and water apparent productivity (US $\$ \mathrm{~m}^{-3}$ ) per irrigation level and year. Colours indicate irrigation level (green rainfed, orange lower irrigation levels 50-150, red higher irrigation levels 200-350, blue full irrigation)

\subsection{Discussion}

The results for the WF obtained in this work are in agreement with similar works by other researchers. In their work assessing the WF of sweeteners and biofuels, GerbensLeenes and Hoekstra, (2012), found average WF values for ethanol production from sugarcane of 2,612 $\mathrm{l} \mathrm{l}^{-1}$ ethanol when computing data from twenty major producers of sugarcane, beet and corn, from 1996 to 2005. This result could be taken as a gross global average of the WF of ethanol production, as it includes result from very different conditions. In the case of Brazilian ethanol the authors presented and average of 1,806, 74 and $14811^{-1}$ for green, blue and grey WF respectively. The lower green WF and higher blue WF of their results compared to ours derive from the different assumptions made in using the Cropwat software.

The methodology used for the calculation of crop water consumption influences significantly the WF results obtained (Hess, 2010). When conducting studies aimed at 
CHAPTER 3: INCREASING EFFICIENCY IN ETHANOL PRODUCTION: WATER FOOTPRINT AND ECONOMIC PRODUCTIVITY OF SUGARCANE ETHANOL UNDER EIGHT IRRIGATION LEVELS IN NORTH-EASTERN BRAZILTHE WATER FOOTPRINT ASSESSMENT OF A PAIR OF JEANS: INFLUENCE OF AGRICULTURAL PRODUCTION IN CONSUMER PRODUCT'S SUSTAINABILITY quantifying the water consumption for the production of sugarcane and other raw materials for obtaining biofuel, Gerbens-Leenes, Hoekstra and Meer (2009) concluded that there is a wide variation of results, mainly due to two factors: the use of different production systems and climate, both of which condition the specific application of water to crops. In this regard, our study shows the variations in the results from different production techniques in a single location.

As for WF studies centred in Brazil, Resende (2011) calculated the volume of water required to produce ethanol in the conditions of the state of São Paulo using the global databases of CLIMWAT 2.0 and FAOSTAT. Their estimation, 2,021 $11^{-1}$, is similar to ours. It is noteworthy that in the region of São Paulo irrigation is hardly used in the cultivation of sugarcane. Under cropping systems in subsurface drip fertigation, in North-eastern Piaui state, Brazil, Andrade Junior et al. (2012), obtained WF values of 1 that ranged from 1483 (1,040 - green water, 338 - blue water, 105 - grey water) to $2081\left(163811^{-1}\right.$ - green water, 227 $11^{-1}$ - blue water, $21611^{-1}$ - grey water). These results were similar to those obtained in our work; however, the physical productivity of sugarcane was significantly higher in their case, $101 \mathrm{t} \mathrm{ha}^{-1}$ for rainfed production. This study did not take into account the provision of subproducts alongside ethanol.

The WF in relative terms, as presented here, is largely related to obtained yields. In terms of crop productivity $\left(\mathrm{t} \mathrm{ha}^{-1}\right)$, yield increases with evapotranspirated water. In treatments without irrigation and those with $50 \mathrm{~mm}$, productivity was below $60 \mathrm{tha}-1$, which is similar to the average for the state of Alagoas. Most of the cultivated area in the state is rainfed. In areas where 100, 150 and $200 \mathrm{~mm}$ were applied, yields averaged $65 \mathrm{tha}-1$, and the average was $74 \mathrm{t} \mathrm{ha}^{-1}$ in the areas that received 250, 300 and $350 \mathrm{~mm}$ of irrigation water. The highest productivity was obtained in the area that received full irrigation with values around $99 \mathrm{t}$ ha ${ }^{1}$, which is well above the averages of Alagoas and Brazil (55 and $80 \mathrm{t} \mathrm{ha}^{-1}$, respectively).

So in order to increase significantly physical water productivity, irrigation applications must be augmented and go beyond 250-300 mm. Although there is little data about irrigated surface at state, regional or national level, the Sugar and Alcohol Industy Union from Alagoas reports that in the 2007/2008 and 2008/2009 crop seasons, 95\% of the irrigated area received one irrigation event or supplemental irrigation (two or three events) representing $55 \%$ of the cultivated surface (Sindaçucar-Al, 2013). Only $2-3 \%$ of the area received full 
CHAPTER 3: INCREASING EFFICIENCY IN ETHANOL PRODUCTION: WATER FOOTPRINT AND ECONOMIC PRODUCTIVITY OF SUGARCANE ETHANOL UNDER EIGHT IRRIGATION LEVELS IN NORTH-EASTERN BRAZILTHE WATER FOOTPRINT ASSESSMENT OF A PAIR OF JEANS: INFLUENCE OF AGRICULTURAL PRODUCTION IN CONSUMER PRODUCT'S SUSTAINABILITY irrigation. However, the trend in the region is to advance towards larger irrigation depths (300-400 mm) or full irrigation with drip systems. The great dynamism of the sector (Martinelli and Filoso, 2008) may imply that already irrigated area share is higher than 55\%, especially the share of area irrigated with large applications. Up to now, there is no information in federal, state or sectorial databases that detail irrigated sugarcane area aside from the limited data presented.

The results of the water apparent productivity point again to the fact that at the farm level improving towards large irrigation depths is a more economically productive way of using water as irrigation than the $50-150 \mathrm{~mm}$ levels. These results are in agreement with Farias et al.(2008) who found that sugarcane water use efficiency increased at least until 50\% ETc was met. As a result, the tendency already observed in sugarcane plantations is to increase irrigation significantly in order to increase productivity and profitability. On the other hand, a limit to this high- irrigation development is the ethanol plant boiling capacity, which limits the amount of juice that may be fermented, and consequently the amount of sugarcane stalks that may be harvested in a short period of time.

From a methodological point of view, some uncertainties in parameters used such as soil water storage capacity and infiltration rate, which strongly influence the results of the WF, suggest the need for more detailed studies. In addition to this, there is a need for an assessment of the possible environmental effects of vinasse application, fertigation with subsurface drip irrigation, and pesticide use and fate in production systems of sugarcane under the conditions of North-east Brazil. This would increase the accuracy of the Grey WF estimations.

\subsection{Conclusions}

This paper describes the present sugarcane production system in North-east Brazil, which represents $7 \%$ of the Brazilian ethanol production, the world's second biggest ethanol producer. The small state of Alagoas alone produced $0.35 \%$ of world ethanol production in 2011. In a context where the national and international demand for biofuels is expected to increase, and considering the concerns over indirect land-use changes with negative environmental consequences (Martinelli and Filoso, 2008), productivity growth stands out as 
CHAPTER 3: INCREASING EFFICIENCY IN ETHANOL PRODUCTION: WATER FOOTPRINT AND ECONOMIC PRODUCTIVITY OF SUGARCANE ETHANOL UNDER EIGHT IRRIGATION LEVELS IN NORTH-EASTERN BRAZILTHE WATER FOOTPRINT ASSESSMENT OF A PAIR OF JEANS: INFLUENCE OF AGRICULTURAL PRODUCTION IN CONSUMER PRODUCT'S SUSTAINABILITY a feasible solution to avoid this negative environmental effect. In the semi-arid Brazilian North-east gains are being achieved through irrigation. The irrigation levels studied in this work proved to have greater relevance than the amount of precipitation in the variation of the WF results. The industrial part of the WF is much smaller compared to that consumed in the production of sugarcane. This way, efforts for a more sustainable water use in the ethanol production should pay particular attention to the agricultural production phase. This may imply supporting alternative agricultural practices to minimize water consumption and impacts on water resources.

The results presented in the study show that under real operating conditions the highest water consumption efficiency in physical terms was achieved either through rainfed production or the application of important water volumes. In economic terms, production with $50-100 \mathrm{~mm}$ levels is less economically efficient than rainfed production and those obtained by applying larger depths. The smallest WF was calculated in areas that did not receive any irrigation. However, these areas had the lowest yields and, therefore, provided the lowest economic profits. This suggests that area cultivated under a rainfed system will become increasingly residual. Among the irrigation levels, the lowest WF results were obtained in areas under full irrigation $(550 \mathrm{~mm})$, followed by those areas receiving $350 \mathrm{~mm}$.

Still, significant differences in the division of the WF were found among the results for rainfed areas, the different irrigation levels and full irrigation. The share of green water diminished while blue WF and grey WF grew as irrigation increased. However, differences in ethanol WF $\left(1 \mathrm{l}^{-1}\right)$ between the lowest water levels (50 to $150 \mathrm{~mm}$ ) and the non-irrigated areas average $9 \%$ if only green and blue WF are taken into account.

As a measure of crop water productivity, these WF results show the water physical and economic productivity gains from sugarcane irrigation. Full irrigation, although having the lowest values of WF, has the highest total water consumption of blue water and highest grey water, an indicator of potential impacts on water quality. In the case of green water, the opportunity cost will be linked to the alternative land uses in the region.

The economic analysis shows the advantages of increasing the irrigation levels, and the increased efficiency (per product, but also economic) of switching from rainfed systems to high irrigation levels. This may contribute to understand the main driver of innovation and change in the production practices. It may also help, if related to other water uses in the 
CHAPTER 3: INCREASING EFFICIENCY IN ETHANOL PRODUCTION: WATER FOOTPRINT AND ECONOMIC PRODUCTIVITY OF SUGARCANE ETHANOL UNDER EIGHT IRRIGATION LEVELS IN NORTH-EASTERN BRAZILTHE WATER FOOTPRINT ASSESSMENT OF A PAIR OF JEANS: INFLUENCE OF AGRICULTURAL PRODUCTION IN CONSUMER PRODUCT'S SUSTAINABILITY region, to provide insights into the effectiveness of water allocation to sustain the regional economy. The increase in the irrigated area poses a potential threat to water resources, but also opens two ways for increasing ethanol production without increasing the pressure on land resources. The first option would be to increase the productivity of rainfed crop through soil and nutrient management or better adapted sugarcane varieties. However, this could be very difficult as water is the limiting factor of the production in the area. A second way for reducing potential impacts would be to improve the efficiency of fertiliser use, by decreasing its leaching, which is particularly relevant in irrigation conditions. As the literature shows, nitrogen and agrochemical leaching are not clearly characterized in sugarcane cultivation, neither is the influence of vinasse applications on it, particularly in the conditions of the Brazilian North-east.

Particularly relevant is the efficiency of water use, that is, the relation of water consumption to water supplied, or the difference between gross and net irrigation. There may also be substantial room for improvement in this indicator, since at present, water application is only grossly adjusted between areas in the different fields. Each sugar mill, as the one studied in this work, cultivates vast areas, so management units are also large. This limits the capability of field and irrigation managers to adapt fertilizing and irrigation to plant needs at a lower scale, which could be a way for improving irrigation efficiency. This also affects adapting irrigation amounts to each particular year's hydrological condition. We have seen how irrigation layers applied were constant for several years.

Nevertheless, the aggregate impacts of generalized irrigation growth and vinasse use in the semi-arid North-east require further study. Regardless of the efficiency achieved, it is the overall water consumption the factor which may affect water availability in the region. Since sugarcane production covers such large areas in small watersheds, even a relatively small increase in the irrigation of sugarcane may greatly increase the pressure on water resources. Moreover, irrigation is carried out soon after harvesting, which is the end of the dry season, and the most fragile period for aquatic ecosystems

Therefore regional studies may complement field-level analyses. In this case, due to the importance of sugarcane in the area, the relative homogeneity of agricultural practices among the mills and their tendency to increase irrigated area, field level productivities may provide 
CHAPTER 3: INCREASING EFFICIENCY IN ETHANOL PRODUCTION: WATER FOOTPRINT AND ECONOMIC PRODUCTIVITY OF SUGARCANE ETHANOL UNDER EIGHT IRRIGATION LEVELS IN NORTH-EASTERN BRAZILTHE WATER FOOTPRINT ASSESSMENT OF A PAIR OF JEANS: INFLUENCE OF AGRICULTURAL PRODUCTION IN CONSUMER PRODUCT'S SUSTAINABILITY insights into regional water use efficiency and its future development, while drive regional total water use.

\subsubsection{Acknowledgments}

We would like to thank Dr. Cariolando Guimarães, and Dr. André Borges and Lucas de Araújo for their support in providing data and explanations on the handling and operation of the distillery. 


\section{THE WATER FOOTPRINT ASSESSMENT OF A PAIR OF JEANS: INFLUENCE OF AGRICULTURAL PRODUCTION IN CONSUMER PRODUCT'S SUSTAINABILITY}

\subsection{Introduction}

It is increasingly recognised that indirect water users, such as consumers, trading, and manufacturing companies, are relevant factors in the path toward a greener economy. More companies are undertaking initiatives to gain a better understanding of their water-related risks along their value chains. Nevertheless, traditional corporate water accounting often fails to address water use and management in the supply chain. Several tools have recently been developed to overcome these limitations: some are accounting tools for water use and operational risk, whereas other approaches aim to introduce the impacts of consumption or to promote a deeper engagement in resource management (Alliance for Water Stewardship, 2012). A reference to most of these tools can be found in the web page of the CEO Water Mandate (CEOWM, 2012). All these initiatives present strengths and weaknesses (UNEP, 2011), and many are still under development (Bayart et al., 2010). It is clear, however, that these tools respond to different views and perspectives (Schornagel et al., 2012).

One such tool is a water footprint assessment. As an indicator, the water footprint (WF) measures the appropriation of water resources by human activity by evaluating water consumption and the impact on water quality. However, the results of water footprint accounting are not completely informative with regard to local sustainability because WF provides only an evaluation of water abstraction or utilisation, with no reference to the local or regional conditions under which it was performed (Jeswani and Azapagic, 2011). To this end, the 'Water Footprint Assessment Manual' (Hoekstra et al., 2011) recommends that the performance of a sustainability assessment be thoroughly checked. This entails the comparison of the water footprint being analysed (product, consumer, or region) with the local water availability, which is obtained from the comparison of the available water resources with the total water footprint of the basin. The available water resources would be the natural runoff (through groundwater and rivers) minus the environmental flow requirements. 
CHAPTER 4: THE WATER FOOTPRINT ASSESSMENT OF A PAIR OF JEANS: INFLUENCE OF AGRICULTURAL PRODUCTION IN CONSUMER PRODUCT'S SUSTAINABILITYINCREASING EFFICIENCY IN ETHANOL PRODUCTION: WATER FOOTPRINT AND ECONOMIC PRODUCTIVITY OF SUGARCANE ETHANOL UNDER EIGHT IRRIGATION LEVELS IN NORTH-EASTERN BRAZILTHE WATER FOOTPRINT ASSESSMENT OF A PAIR OF JEANS: INFLUENCE OF AGRICULTURAL PRODUCTION IN CONSUMER PRODUCT'S SUSTAINABILITY

To better assess the impacts and allow comparability among different WFs, some authors have suggested that water footprints be weighted by a scarcity factor (Ridoutt et al., 2011), in accordance with Life Cycle Assessment (LCA) methodology (Koehler, 2008). Several indexes have been proposed to this end. Pfister et al. (2009) proposed three areas of protection, human health, ecosystem quality, and resources, and discussed a global characterisation and the damage factors for watershed-level consumptive water use, applying them to global cotton production. Pfister et al. (2009) and Milà i Canals et al. (2009) proposed two impact pathways for water use and corresponding characterisation factors, and, based on the water stress index of Pfister et al. (2009), Ridoutt and Pfister (2012) developed a characterisation factor for water footprint assessments. The application of different methodologies for impact assessment leads to different results, necessitating a more standardised methodology (Jeswani and Azapagic, 2011). Page et al. (2011) recognises the need for an improvement of the impact assessment at the endpoint level. Measuring water scarcity is a complex process that depends on the spatial and temporal scales of the analysis (Rijsberman, 2006). Recently, Jefferies et al. (2012) considered the synergy of LCA and WFA methodologies and identified the differences in scope and focus of both methods. The blue water footprint may serve in the inventory phase of the LCA assessment, though green and grey WFs are usually recommended for accounting in other impact categories (Milá i Canals, 2009; Pfister et al., 2009). Several papers have recently applied the different methodologies for water footprint accounting and impact assessment. Jeswani and Azapagic (2011) applied different methodologies to the case of corn-based ethanol in 12 countries. Jefferies at al. (2012) studied two Unilever products, margarine and tea, from cradle to gate. Zonderland-Thomassen and Ledgard (2012) analysed two different dairy farming systems in New Zealand. Herath et al. (2013a, 2013b) applied a water balance approach to two wine production systems in New Zealand, obtaining negative water footprints for the grape growing stage. These articles agree that the LCA and the WF communities share the same challenges with regard to the assessment of products. Assessing the environmental impacts of water use, in a comprehensive, robust way is a complex task. There is a balance to be achieved between spatial detail of the impact assessment, which greatly increases accuracy but is highly data demanding, and the applicability of the method at larger scales, which is needed for methodologies trying to asses worldwide supply chains. Potential synergies exist because they 
CHAPTER 4: THE WATER FOOTPRINT ASSESSMENT OF A PAIR OF JEANS: INFLUENCE OF AGRICULTURAL PRODUCTION IN CONSUMER PRODUCT'S SUSTAINABILITYINCREASING EFFICIENCY IN ETHANOL PRODUCTION: WATER FOOTPRINT AND ECONOMIC PRODUCTIVITY OF SUGARCANE ETHANOL UNDER EIGHT IRRIGATION LEVELS IN NORTH-EASTERN BRAZILTHE WATER FOOTPRINT ASSESSMENT OF A PAIR OF JEANS: INFLUENCE OF AGRICULTURAL PRODUCTION IN CONSUMER PRODUCT'S SUSTAINABILITY

rely on the same data for water accounting and impact assessment and would benefit from further collaboration and the joint development of methods.

One of the strengths of WF is the transparency of the results, as water consumption estimates may be disaggregated at the lowest possible level, affording more flexibility for evaluating the impacts of water consumption spatially and temporally. Indeed, one of the issues that LCA is improving in its impact assessment phase is the temporal and spatial definition of the characterisation factors, which are still not completely and satisfactorily developed (Jeswani and Azapagic, 2011). Nonetheless, the broad scope of LCA avoids problem-shifting (Cucek et al., 2012)

These initiatives have catalysed significant progress for achieving more sustainable corporate water management, as in the case of the apparel sector. For example, the Better Cotton Initiative (BCI, 2012) is a joint project of relevant international companies of this sector with NGOs (WWF) and local organisations to promote the best farming practices for cotton growers in Brazil, Pakistan, India, and Mali. In addition to water, these practices are also focused on integrated pest management, working conditions, and soil conservation. The Sustainable Apparel Coalition is a joint effort of global companies for the development of a tool to measure the social and environmental performance of the products (SAC, 2012). Examples of certifications by third parties are the labels OEKO-TEX® Standard from International Association for Research and Testing in the Field of Textile Ecology, "Blue Sign" from Blue Sign AG, "Made in Green" by Aitex, and "Eco-label" from the European Union Commission, this last being applicable to other non-textile products. Muthu et al. (2012) have proposed an Ecological Sustainability Index specific for textile fibres, with 9 impact categories and a scoring system, indicating organic cotton as being a more environmentally friendly fibre than other natural and, in particular, man-made fibres. However, this approach is heavily dependent on the weighting factors chosen for each impact category.

Very few studies have been devoted to analyse the water footprint of cotton textiles. Mekonnen and Hoekstra (2011) reported that cotton accounts for 3.14\% of the world's total water footprint. The authors estimated that the global average water footprint of cotton lint 
CHAPTER 4: THE WATER FOOTPRINT ASSESSMENT OF A PAIR OF JEANS: INFLUENCE OF AGRICULTURAL PRODUCTION IN CONSUMER PRODUCT'S SUSTAINABILITYINCREASING EFFICIENCY IN ETHANOL PRODUCTION: WATER FOOTPRINT AND ECONOMIC PRODUCTIVITY OF SUGARCANE ETHANOL UNDER EIGHT IRRIGATION LEVELS IN NORTH-EASTERN BRAZILTHE WATER FOOTPRINT ASSESSMENT OF A PAIR OF JEANS: INFLUENCE OF AGRICULTURAL PRODUCTION IN CONSUMER PRODUCT'S SUSTAINABILITY

is 5163,2955 , and $966 \mathrm{~m}^{3} / \mathrm{t}$ for green, blue, and grey water, respectively; this average ranges from 5020, 0, and $1065 \mathrm{~m}^{3} / \mathrm{t}$ in Minas Gerais, Brazil, to 34923, 0, and 2213 in Gambia (where production is based on green water) or 18, 4886, and $396 \mathrm{~m}^{3} / \mathrm{t}$ in Syrian Dar'a region to 272, 21737, and $267 \mathrm{~m}^{3} / \mathrm{t}$ in the Afghan Nimruz region (where production depends on blue water). In a previous article focused on cotton production, Chapagain et al. (2006) quantified the global cotton water footprint at $256 \mathrm{Gm}^{3} / \mathrm{y}$, with a global average of 4264, 4242, and 622 $\mathrm{m}^{3} / \mathrm{t}$ for green, blue, and grey water, respectively. Using the LCA approach, Pfister et al. (2009) quantified the global average of (blue) water consumptive use for cotton production at $8540 \mathrm{~m}^{3} / \mathrm{t}$ and proposed a methodology to account for water consumption and related impacts within LCA methodology.

The goal of this paper is to evaluate the water footprint of a consumer product, denim trousers (blue jeans), by examining different raw materials and production methods along the entire value chain. Many textile products, including jeans, are produced using different combinations of cotton fibres with other synthetic fibres, such as Lyocell fibre, which is produced with cellulose from the timber of different tree species. Furthermore, jean trousers are manufactured following widely different and environmentally sensitive production methods. Our study includes five different fabrics made from cotton and Lyocell fibres. In particular, the study focuses on the example of cotton production in 3 river basins in southern Spain. To evaluate how sensitive our water assessment is to some important factors, this paper analyses how the influence of cotton prices and sectoral policies on the production methods impacts the sustainability of a specific consumer product. The drivers of these different production methods affect the result of the product's WF and, therefore, need to be taken into account in an evaluation of the WF of a product. The analysis of the sustainability of the critical points in the product's WF is performed in two ways: the monthly water stress index (WSI), as proposed in Hoekstra et al. (2012), is calculated using the local data; the results are then discussed with the local actual outflow data and available water storage in dams. 
CHAPTER 4: THE WATER FOOTPRINT ASSESSMENT OF A PAIR OF JEANS: INFLUENCE OF AGRICULTURAL PRODUCTION IN CONSUMER PRODUCT'S SUSTAINABILITYINCREASING EFFICIENCY IN ETHANOL PRODUCTION: WATER FOOTPRINT AND ECONOMIC PRODUCTIVITY OF SUGARCANE ETHANOL UNDER EIGHT IRRIGATION LEVELS IN NORTH-EASTERN BRAZILTHE WATER FOOTPRINT ASSESSMENT OF A PAIR OF JEANS: INFLUENCE OF AGRICULTURAL PRODUCTION IN CONSUMER PRODUCT'S SUSTAINABILITY

\subsection{Methodology}

Our study analyses the water footprint of a range of fabrics made in Spain, from the origin of the raw material to the garment cutting and production of the final piece. Four of these fabrics are made from cotton, whereas the fifth is composed of Lyocell fibre, a textile fibre obtained from wood cellulose. The methodology was based on the water footprint assessment developed in Hoekstra et al. (2011). The green, blue, and grey water footprints of the processes in the textile value chain were estimated from the wood and cotton production stage to the industrial processes. Figures $7 \mathrm{a}$ and $7 \mathrm{~b}$ detail the production phases, the type of water included in the calculation, and the type of data source used. The system boundaries excluded the WF of transport and electricity and that of the packaging and manufacture of minor inputs to production. 
CHAPTER 4: THE WATER FOOTPRINT ASSESSMENT OF A PAIR OF JEANS: INFLUENCE OF AGRICULTURAL PRODUCTION IN CONSUMER PRODUCT'S SUSTAINABILITYINCREASING EFFICIENCY IN ETHANOL PRODUCTION: WATER FOOTPRINT AND ECONOMIC PRODUCTIVITY OF SUGARCANE ETHANOL UNDER EIGHT IRRIGATION LEVELS IN NORTH-EASTERN BRAZILTHE WATER FOOTPRINT ASSESSMENT OF A PAIR OF JEANS: INFLUENCE OF AGRICULTURAL PRODUCTION IN CONSUMER PRODUCT'S SUSTAINABILITY

Cotton textile production Chain

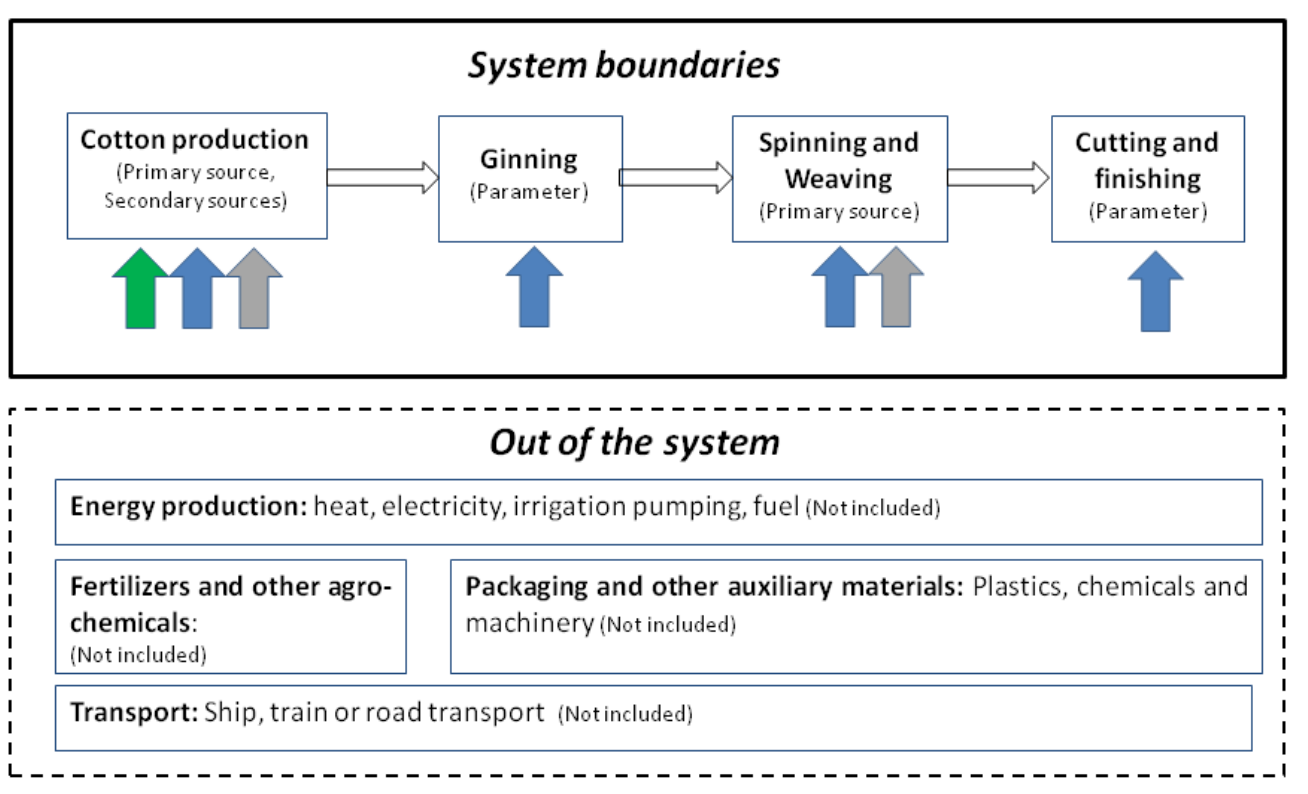

\section{Lyocell textile production Chain}
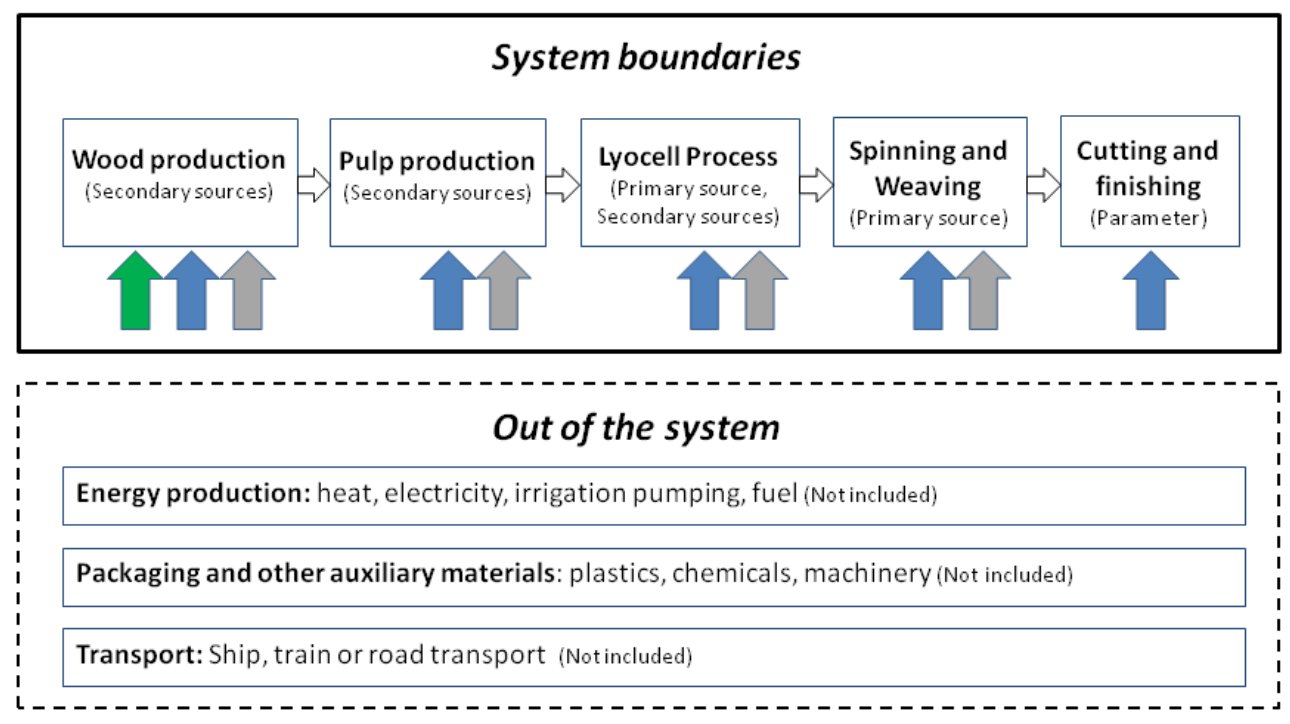

Figure 6.- System boundaries of the production chain for cotton and Lyocell fibres, data source per process, and type of water taken into account per stage. The colour of the arrows indicates the type of water consumed at each point (green water, blue water and grey water) 
CHAPTER 4: THE WATER FOOTPRINT ASSESSMENT OF A PAIR OF JEANS: INFLUENCE OF AGRICULTURAL PRODUCTION IN CONSUMER PRODUCT'S SUSTAINABILITYINCREASING EFFICIENCY IN ETHANOL PRODUCTION: WATER FOOTPRINT AND ECONOMIC PRODUCTIVITY OF SUGARCANE ETHANOL UNDER EIGHT IRRIGATION LEVELS IN NORTH-EASTERN BRAZILTHE WATER FOOTPRINT ASSESSMENT OF A PAIR OF JEANS: INFLUENCE OF AGRICULTURAL PRODUCTION IN CONSUMER PRODUCT'S SUSTAINABILITY

\subsubsection{Cotton production in Spain}

Spain and Greece are the only EU countries that produce cotton. Although cotton is not one of the main crops in Spain, it is relevant in the producing areas, which are traditionally concentrated in the middle and lower Guadalquivir river and the Guadalete and Barbate rivers (see the map in Figure 7). In 2005 and 2009, this production area represented approximately $15 \%$ and $8 \%$, respectively, of the total irrigated surface in the Guadalquivir basin, exceeding 30\% in some municipalities. According to the River Basin District Management Plan, cotton is the most extended irrigated crop in the Guadalquivir basin after olive trees (RBDMP, DHG, 2012).

The cultivated area exceeded 100,000 ha in 1999 but decreased to 86,000 ha in 2005 and to a minimum of 52,639 ha in 2008 (MAGRAMA, 2012). There was a partial recovery in the cultivated surface during 2009-2011, to 66,500 ha in 2011, which was linked to a $62 \%$ rise in international prices with respect to the average 2007-2009 prices (Cotton Outlook, 2012). Irrigation is utilised in $93 \%$ of the planted cotton area in Spain, and different techniques, such as surface, drip, and sprinkler systems, are employed. Before 2006, cotton was cultivated under plastic mulching, and a variety of agrochemicals were used, including fertilisers, phytosanitary products, and defoliants. Cotton is an intensive crop and generates significant socioeconomic revenues in terms of agricultural (Arriaza and Capellán, 2009) and associated income (JA, 2005).

Cotton production in Spain was affected by the partial decoupling ${ }^{3}$ of the EU Common Agricultural Policy (CAP) from 2006 (Arriaza and Capellán, 2009). The decoupling reform introduced a change from receiving a payment per unit produced to receiving a basic payment per cultivated surface. Many farmers have either substituted cotton with other crops or have reduced the variable costs by reducing the number of irrigation applications (and water applied) and fertiliser and phytosanitary product usage. Integrated pest management practices spread to $75 \%$ of the surface area, which added $350 € /$ ha in payments and implied

\footnotetext{
${ }^{3}$ Decoupling: Introduced by the 2003 reform of the EU common agricultural policy, decoupling is the removal of the link between the receipt of a direct payment and the production of a specific product Source: EC (2013).
} 
CHAPTER 4: THE WATER FOOTPRINT ASSESSMENT OF A PAIR OF JEANS: INFLUENCE OF AGRICULTURAL PRODUCTION IN CONSUMER PRODUCT'S SUSTAINABILITYINCREASING EFFICIENCY IN ETHANOL PRODUCTION: WATER FOOTPRINT AND ECONOMIC PRODUCTIVITY OF SUGARCANE ETHANOL UNDER EIGHT IRRIGATION LEVELS IN NORTH-EASTERN BRAZILTHE WATER FOOTPRINT ASSESSMENT OF A PAIR OF JEANS: INFLUENCE OF AGRICULTURAL PRODUCTION IN CONSUMER PRODUCT'S SUSTAINABILITY

limitations on pesticide and fertiliser use (JA, 2007). Plastic-mulched area disappeared, rainfed areas increased from 5 to 10\%, and drip and furrow irrigation decreased (Granado et al., 2008). Although the average yields were $3,500 \mathrm{~kg} / \mathrm{ha}$ in the $1995-2005$ period, similar to the main producing countries worldwide, the yields decreased to 2,500 and 1,100 kg/ha in 2007 and 2008, respectively, particularly in Seville province, which accounts for more than $60 \%$ of the cultivated area (MAGRAMA, 2012). Furthermore, due to the few crop alternatives in the region, direct farm labour decreased an average of 43\% (JA, 2007).

\subsection{Water accounting}

\subsubsection{Fibre production stage}

The green and blue water consumption of the cotton production stage in the Guadalquivir, Guadalete, and Barbate river basins was calculated with the software CROPWAT (FAO, 2009). The calculation was performed at the municipal level, distinguishing among the different irrigation techniques for 2005 and 2009. The monthly precipitation and potential evapotranspiration were obtained at the agricultural district level from the irrigation service of the regional government (SIAR, 2012). The crop evapotranspiration coefficient (Kc) was obtained from Allen et al. (2006). Even though 2005 was a dry year, with precipitation approximately $50 \%$ of the average, it was declared a normal year in terms of drought risk because of the water stored in reservoirs (MAGRAMA, 2009). In contrast, 2009 was a normal year in terms of precipitation and drought risk (DHG, 2009), though only $50 \%$ of the crop irrigation water requirements were satisfied (García -Vila et al., 2008; Arriaza and Capellán, 2009). Data for the cotton crop area at the municipal level were obtained from the Spanish Ministry of Agriculture, Food and Environment (MAGRAMA, 2012). The yield and share of area per irrigation technique and province were obtained from the cotton production statistics of the Andalusian government (JA, 2007). The green and blue water footprint of the cotton production $\left(\mathrm{m}^{3} / \mathrm{t}\right.$ ) was calculated using the estimated green and blue water consumption and the yield per province and irrigation type (rainfed and surface, sprinkler, or drip irrigation). 
CHAPTER 4: THE WATER FOOTPRINT ASSESSMENT OF A PAIR OF JEANS: INFLUENCE OF AGRICULTURAL PRODUCTION IN CONSUMER PRODUCT'S SUSTAINABILITYINCREASING EFFICIENCY IN ETHANOL PRODUCTION: WATER FOOTPRINT AND ECONOMIC PRODUCTIVITY OF SUGARCANE ETHANOL UNDER EIGHT IRRIGATION LEVELS IN NORTH-EASTERN BRAZILTHE WATER FOOTPRINT ASSESSMENT OF A PAIR OF JEANS: INFLUENCE OF AGRICULTURAL PRODUCTION IN CONSUMER PRODUCT'S SUSTAINABILITY

Because the amount of fertilisation needed depends, among other factors, on the crop, soil, agricultural practices, and expected yield, we considered the impact of nitrogen fertilisation to estimate the grey water footprint of cotton production. The grey water footprint was calculated by estimating the excess nitrogen leached. The crop nitrogen extraction was considered to be $50 \mathrm{kgN} / \mathrm{t}$ of raw cotton produced (Lopez Bellido, 2003), and this figure was multiplied by the crop yield per irrigation technique to obtain the total nitrogen extractions per ha. In 2004, an average of $200 \mathrm{kgN} /$ ha was applied, whereas it fell to only $90 \mathrm{kgN} / \mathrm{ha}$ in 2008 (Arriaza and Capellán, 2009). The difference between nitrogen extraction and applied nitrogen was considered as the excess nitrogen from which $15 \%$ is leached in the Guadalquivir valley according to Velthoft et al. (2007). Leaching was assumed to be negligible in the case of rainfed production. The nitrogen concentration limit was considered to be $50 \mathrm{mg} \mathrm{NO}_{3}^{-} / 1$, in accordance with the EU Nitrates Directive (EC, 2002; EU 91/676/EEC)

Only the water incorporated into the product was taken into accountin the cottonginning phase, which occurs with dried cotton (humidity is lowered from 7-9\% to 3-5\%). This humidity content is restored at the end of the process to avoid fire risk and to facilitate the ensuing industrial phases (López-Bellido, 2003).

With regard to the Lyocell fibre, the calculation of the green water footprint of wood production was performed by estimating the evapotranspiration of deciduous forests in Europe (Van Oel and Hoekstra, 2012). The wood yield and pulp processing processes were according to the LCA published by the Lenzing Group (Shen and Patel, 2010). The estimations of processing water used in pulp production were based on the working draft of best available technologies for Kraft processes, non-integrated pulp mills (EC, 2012). The estimation of water consumption in the production phase was based on the data supplied by the producing company, Lenzing Group. The emission values of the Lyocell and pulp production processes were obtained from the Austrian standard for surface water quality for this sector (BLFUW, 2000a; 2000b). 
CHAPTER 4: THE WATER FOOTPRINT ASSESSMENT OF A PAIR OF JEANS: INFLUENCE OF AGRICULTURAL PRODUCTION IN CONSUMER PRODUCT'S SUSTAINABILITYINCREASING EFFICIENCY IN ETHANOL PRODUCTION: WATER FOOTPRINT AND ECONOMIC PRODUCTIVITY OF SUGARCANE ETHANOL UNDER EIGHT IRRIGATION LEVELS IN NORTH-EASTERN BRAZILTHE WATER FOOTPRINT ASSESSMENT OF A PAIR OF JEANS: INFLUENCE OF AGRICULTURAL PRODUCTION IN CONSUMER PRODUCT'S SUSTAINABILITY

\subsubsection{Fabric production stage}

Five different fabric types where considered for fabric production (spinning, dyeing, and weaving stages). All of the fabrics differ in their final characteristics, covering the main categories of textile for trousers, and included two cotton denim materials (colours 82 and 212) plus two other cotton fabrics, one dyed in the weaving phase and one "ready to dye" or dyed after the weaving phase in a separate phase, and one Lyocell fibre denim fabric (colour $390)$.

The water footprint per unit will be influenced by the subsequent processes (spinning, dying, weaving, and finishing), which depend on the characteristics of the final product. In this study, all of the water consumed in the spinning and weaving phases was measured in a fabric-producing plant of the company Tejidos Royo in Picassent (Spain). AITEX, the Textile Industry Research Association, collaborated in the data collection. The water consumed depends on the different processes followed to obtain a specific fabric, particularly for the dying with indigo and subsequent washing steps.

The grey water footprint was calculated with the effluent chemical oxygen demand of the factory and compared to the specific discharge permitted by the municipal authorities. Both the spinning and weaving steps occur in the same factory, and the grey water footprint was estimated jointly. The calculation of the garment's WF (jean trousers) was estimated by considering an average weight of $780 \mathrm{~g}$ per unit. The water used in the confection phase was not taken into account.

\subsubsection{Blue water impact assessment}

The blue water footprint impact assessment was performed in the cotton production phase by following the methodology of the Water Footprint Assessment Manual (Hoekstra et al., 2011). The methodology includes the estimation of the blue water stress index per month at the river basin level. This index is the ratio of the total blue WF in the study area to the blue water availability (BWA). This availability is calculated as the difference between the river flow under natural conditions and the environmental minimum flow requirements (EFRs): 
CHAPTER 4: THE WATER FOOTPRINT ASSESSMENT OF A PAIR OF JEANS: INFLUENCE OF AGRICULTURAL PRODUCTION IN CONSUMER PRODUCT'S SUSTAINABILITYINCREASING EFFICIENCY IN ETHANOL PRODUCTION: WATER FOOTPRINT AND ECONOMIC PRODUCTIVITY OF SUGARCANE ETHANOL UNDER EIGHT IRRIGATION LEVELS IN NORTH-EASTERN BRAZILTHE WATER FOOTPRINT ASSESSMENT OF A PAIR OF JEANS: INFLUENCE OF AGRICULTURAL PRODUCTION IN CONSUMER PRODUCT'S SUSTAINABILITY

$\mathrm{Eq}[1] \quad \mathrm{WS}_{\text {Blue }}[\mathrm{x}, \mathrm{t}]=\sum \mathrm{WF}_{\text {Blue }}[\mathrm{x}, \mathrm{t}] /\left(\mathrm{R}_{\mathrm{nat}}[\mathrm{x}, \mathrm{t}]-\operatorname{EFR}[\mathrm{x}, \mathrm{t}]\right)$

where

$\mathrm{WS}_{\text {blue }}[\mathrm{x}, \mathrm{t}]$ is the blue water scarcity (dimensionless) per river basin, $\mathrm{x}$, and time frame (month), t;

$\mathrm{WF}_{\text {blue }}[\mathrm{x}, \mathrm{t}]$ is the total blue water footprint per river basin and month $\left(\mathrm{Mm}^{3} / \mathrm{y}\right)$;

$\mathrm{R}_{\mathrm{nat}}[\mathrm{x}, \mathrm{t}]$ is the natural runoff in the catchment for a time frame (month) $\left(\mathrm{Mm}^{3} / \mathrm{y}\right)$; and

EFR $[\mathrm{x}, \mathrm{t}]$ is the environmental flow requirement $\left(\mathrm{Mm}^{3} / \mathrm{y}\right)$.

This index considers the theoretical natural runoff (not the actual runoff) as the basis for the estimation of the water availability (the denominator in Eq 1), as suggested by Hoekstra et al. (2011). In our case, we divided the Guadalquivir and the Guadalete and Barbate River Basin District into smaller sub-basins that served as the study areas so that the different information could be combined. The EFR at the end of each sub-basin was known, as it is given in the River Basin District Management Plan (RBDMP).

In this work, we also took into account the available water stored in dams. This was estimated as the actual monthly volume stored in the dams in those years minus the dependent urban and industrial demands and the environmental minimum requirement for each dam, as calculated for each study area. Thus, an adjusted WSI index was calculated. 
CHAPTER 4: THE WATER FOOTPRINT ASSESSMENT OF A PAIR OF JEANS: INFLUENCE OF AGRICULTURAL PRODUCTION IN CONSUMER PRODUCT'S SUSTAINABILITYINCREASING EFFICIENCY IN ETHANOL PRODUCTION: WATER FOOTPRINT AND ECONOMIC PRODUCTIVITY OF SUGARCANE ETHANOL UNDER EIGHT IRRIGATION LEVELS IN NORTH-EASTERN BRAZILTHE WATER FOOTPRINT ASSESSMENT OF A PAIR OF JEANS: INFLUENCE OF AGRICULTURAL PRODUCTION IN CONSUMER PRODUCT'S SUSTAINABILITY

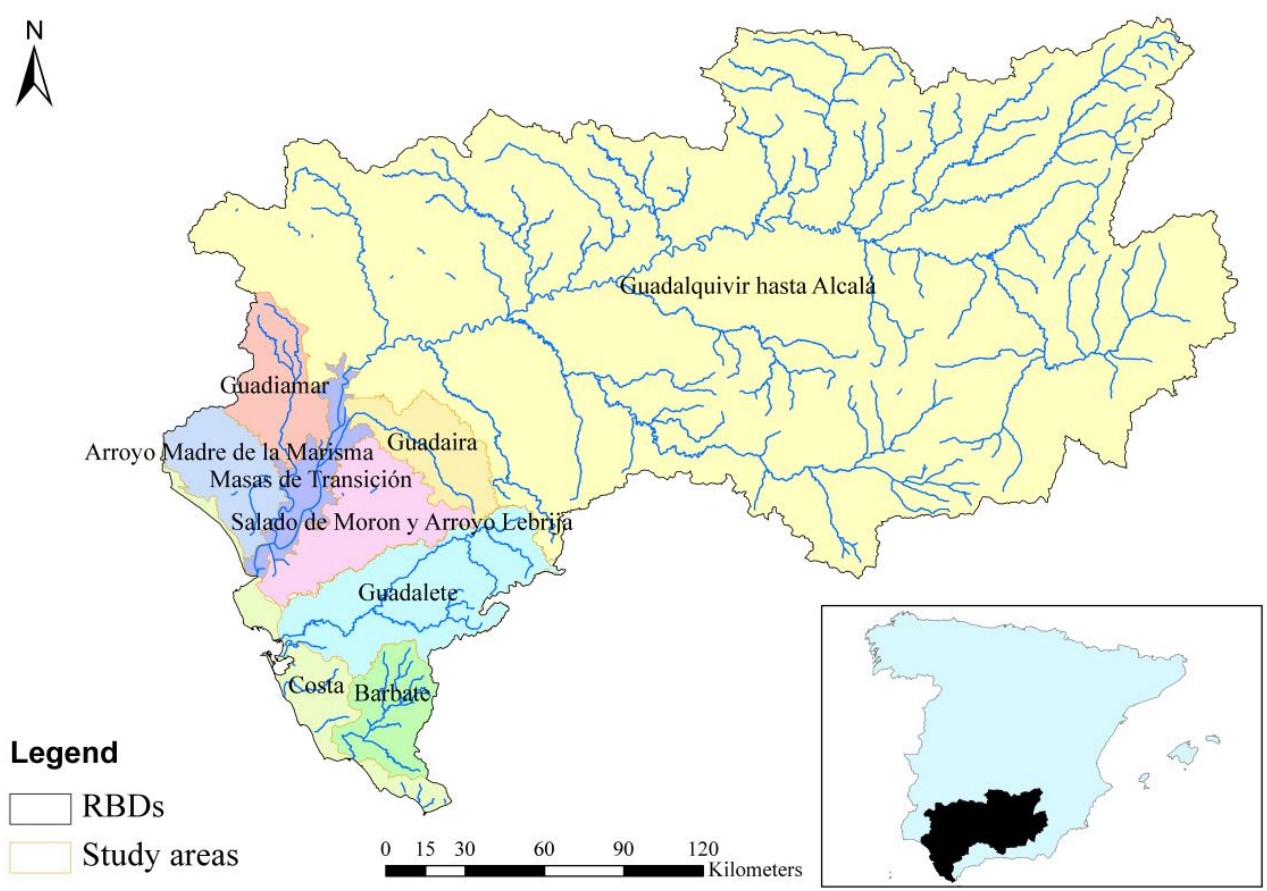

Figure 7.- Study areas and main rivers in the Guadalquivir, Guadalete, and Barbate river basins

The blue water footprint per crop, year, and municipality was estimated for all the study areas by following the methodology in Salmoral et al. (2011a), as based on Garrido et al. (2010), and taking into account irrigation limitations as a consequence of the drought level per irrigation district. A more realistic estimation of the blue WF of crop production may be obtained in this way. The estimated yearly crop WF was distributed among the different months of the year according to the estimated blue water requirements in Garrido et al. (2010). The blue WF of all crops and municipalities of a study area was then aggregated using the information of the crop irrigated surface at the municipal level given by the Ministry of Agriculture, Food and Environment. For municipalities that are located partly outside of the basin or that are situated in more than one study area, the municipalities' water consumption was assigned to each study area proportionally based on the area of the municipality inside the study area. The result is the crop blue WF of the study area, which is equal to the total blue WF of the study area in Eq 1, and was used for the calculation of blue water availability. In the Guadalquivir basin, the crop blue WF represents $80 \%$ of the total blue WF of all uses (Salmoral et al., 2011a). 
CHAPTER 4: THE WATER FOOTPRINT ASSESSMENT OF A PAIR OF JEANS: INFLUENCE OF AGRICULTURAL PRODUCTION IN CONSUMER PRODUCT'S SUSTAINABILITYINCREASING EFFICIENCY IN ETHANOL PRODUCTION: WATER FOOTPRINT AND ECONOMIC PRODUCTIVITY OF SUGARCANE ETHANOL UNDER EIGHT IRRIGATION LEVELS IN NORTH-EASTERN BRAZILTHE WATER FOOTPRINT ASSESSMENT OF A PAIR OF JEANS: INFLUENCE OF AGRICULTURAL PRODUCTION IN CONSUMER PRODUCT'S SUSTAINABILITY

The data for the natural river flow $\left(\mathrm{R}_{\mathrm{nat}}\right)$ was obtained from RBDMP and is based on the SIMPA hydrological model (Estrela and Quintas, 1996), which is used by the Spanish River Basin authorities in their resource estimation. This model estimates the total runoff per 100x100-m grid cell. The average 1940/41-2005/06 monthly accumulated runoff at the study area's endpoint was used. The ecological flow at the end of the study areas and the municipal urban and industrial water demand and ecological flow at the end of each dam was obtained from the RBDMP (DHG, 2012 in the Guadalquivir and AAA, 2010 in the Guadalete and Barbate basins). The stored capacity in dams and dam outflow at the end of the study areas were obtained from the River Basin District information tool (SAIH, 2012).

As stated in RBDMP, the environmental flows of the Guadalquivir's estuary (Transition Water bodies) are complex and depend on the sea dynamics; thus these factors are not included in the present analysis. The same reasoning was applied to small coastal rivers. The different information was geographically added using ArcGIS 9.3.

\subsection{Results}

\subsubsection{Water accounting}

Table 3 shows the maximum, minimum, and average water footprints in each production stage in both production chains (cotton and Lyocell) and the final WF per item. 
CHAPTER 4: THE WATER FOOTPRINT ASSESSMENT OF A PAIR OF JEANS: INFLUENCE OF AGRICULTURAL PRODUCTION IN CONSUMER PRODUCT'S SUSTAINABILITYINCREASING EFFICIENCY IN ETHANOL PRODUCTION: WATER FOOTPRINT AND ECONOMIC PRODUCTIVITY OF SUGARCANE ETHANOL UNDER EIGHT IRRIGATION LEVELS IN NORTH-EASTERN BRAZILTHE WATER FOOTPRINT ASSESSMENT OF A PAIR OF JEANS: INFLUENCE OF AGRICULTURAL PRODUCTION IN CONSUMER PRODUCT'S SUSTAINABILITY

Table 3.- Maximum, minimum and average green, blue and grey water footprint ( $\mathrm{m}^{3} / \mathrm{t}$ product) in each production stage and total WF per trouser $\left(\mathrm{m}^{3} /\right.$ piece $)$

\begin{tabular}{|c|c|c|c|c|c|c|c|c|c|c|c|c|c|}
\hline \multirow{3}{*}{$\begin{array}{l}\text { Cotton } \\
\text { products }\end{array}$} & \multicolumn{3}{|c|}{ Cotton Lint $\left(\mathrm{m}^{3} / \mathrm{t}\right)$} & \multicolumn{3}{|c|}{ Ginning $\left(\mathrm{m}^{3} / \mathrm{t}\right)$} & \multicolumn{3}{|c|}{$\begin{array}{l}\text { Spinning and Weaving } \\
\left(\mathrm{m}^{3} / \mathrm{t} \text { fabric }\right)\end{array}$} & \multicolumn{4}{|c|}{$\begin{array}{l}\text { Total WF of cotton trousers } \\
\left(\mathrm{m}^{3} / \text { item }\right)\end{array}$} \\
\hline & green & blue & grey & green & blue & grey & green & blue & grey & green & blue & grey & total WF \\
\hline & WF & WF & WF & WF & WF & WF & WF & WF & WF & WF & WF & WF & \\
\hline & & & & & & & & & & & & & 4894 \\
\hline $\operatorname{Max}\left(\mathrm{m}^{3} / \mathrm{t}\right)$ & 879 & 6339 & 550 & 0 & 30 & 0 & 0 & 134.3 & 0.06 & 544 & 4008 & 341 & \\
\hline & & & & & & & & & & & & & 2797 \\
\hline $\operatorname{Min}\left(\mathrm{m}^{3} / \mathrm{t}\right)$ & 302 & 3862 & 272 & 0 & 60 & 0 & 0 & 53.5 & 0 & 187.9 & 2439.4 & 169.4 & \\
\hline $\begin{array}{l}\text { Average } \\
\left(\mathrm{m}^{3} / \mathrm{t}\right)\end{array}$ & 422 & 4380 & 326 & 0 & 40 & 0 & 0 & 91.76 & 0.06 & 263 & 2767 & 203 & 3233 \\
\hline
\end{tabular}

\begin{tabular}{|c|c|c|c|c|c|c|c|c|c|c|c|c|c|}
\hline \multirow{2}{*}{$\begin{array}{l}\text { Lyocell } \\
\text { Fibre } \\
\text { products }\end{array}$} & \multicolumn{3}{|c|}{ Wood Growth $\left(\mathrm{m}^{3} / \mathrm{t}\right)$} & \multicolumn{3}{|c|}{$\begin{array}{c}\text { Fibre production } \\
\text { (market pulp }+ \text { Lyocell } \\
\text { process) }\end{array}$} & \multicolumn{3}{|c|}{$\begin{array}{l}\text { Spinning and Weaving } \\
\left(\mathrm{m}^{3} / \mathrm{t} \text { fabric }\right)\end{array}$} & \multicolumn{4}{|c|}{$\begin{array}{l}\text { Total WF of Lyocell trousers } \\
\left(\mathrm{m}^{3} / \text { item }\right)\end{array}$} \\
\hline & $\begin{array}{l}\text { green } \\
\text { WF }\end{array}$ & $\begin{array}{l}\text { blue } \\
\text { WF }\end{array}$ & $\begin{array}{l}\text { grey } \\
\text { WF }\end{array}$ & $\begin{array}{l}\text { green } \\
\text { WF }\end{array}$ & $\begin{array}{l}\text { blue } \\
\text { WF }\end{array}$ & $\begin{array}{l}\text { grey } \\
\text { WF }\end{array}$ & $\begin{array}{l}\text { green } \\
\text { WF }\end{array}$ & $\begin{array}{l}\text { blue } \\
\text { WF }\end{array}$ & $\begin{array}{l}\text { grey } \\
\text { WF }\end{array}$ & $\begin{array}{l}\text { green } \\
\text { WF }\end{array}$ & $\begin{array}{l}\text { blue } \\
\text { WF }\end{array}$ & $\begin{array}{l}\text { grey } \\
\text { WF }\end{array}$ & total WF \\
\hline $\operatorname{Max}\left(\mathrm{m}^{3} / \mathrm{t}\right)$ & 1012 & 0 & 0 & 0 & - & 3.71 & 0 & 104.8 & 0.06 & 1652.9 & 46.7 & 175.6 & \\
\hline $\begin{array}{l}\operatorname{Min}\left(\mathrm{m}^{3} / \mathrm{t}\right) \\
\text { Average } \\
\left(\mathrm{m}^{3} / \mathrm{t}\right)\end{array}$ & 847.1 & 0 & 0 & 0 & 0 & 272.1 & 0 & 104.8 & 0.06 & 1115 & 46.4 & 35.3 & 1454 \\
\hline
\end{tabular}

Source: Own elaboration based on own calculations, data collected in Tejidos Royo with the help of AITEX and data supplied by Lenzing Group. 
CHAPTER 4: THE WATER FOOTPRINT ASSESSMENT OF A PAIR OF JEANS: INFLUENCE OF AGRICULTURAL PRODUCTION IN CONSUMER PRODUCT'S SUSTAINABILITYINCREASING EFFICIENCY IN ETHANOL PRODUCTION: WATER FOOTPRINT AND ECONOMIC PRODUCTIVITY OF SUGARCANE ETHANOL UNDER EIGHT IRRIGATION LEVELS IN NORTH-EASTERN BRAZILTHE WATER FOOTPRINT ASSESSMENT OF A PAIR OF JEANS: INFLUENCE OF AGRICULTURAL PRODUCTION IN CONSUMER PRODUCT'S SUSTAINABILITY

In the process of the Lyocell fibre, the main consumption lies in the wood growth stage, which relies mainly on green water, and the water footprint of wood varies depending on the origin of the wood and forest type (Van Oel and Hoekstra, 2012). The maximum values shown here account for broadleaf forest from central Europe, the actual origin of the wood, and the minimum values account for temperate eucalyptus forests from South Africa, an alternative wood source that is used by the company to produce fibres other than Lyocell (Shen and Patel, 2010). These values are averages of various years and locations. Other possible wood origins were not considered because, as provided by the manufacturer company, the sources used are those from which the wood for Lyocell fibre may ultimately be derived.

Both cellulose pulp production and fibre production from the pulp exhibit a lower water footprint than the wood growth phase, albeit of a different nature. Green water is the main component in the wood growth phase, whereas grey water is dominant in the industrial phases. The existing technologies allow for industrial plants to almost completely reuse the water used in their processes, and the effluents are reportedly within the legal environmental limits. This causes the industrial WF to be small. Water consumption and pollution in the spinning and weaving phases differ according to the specifications of the fabric and are mainly related to the final colour and appearance of the product. Different processes are followed to achieve these specifications. Dying, for example, requires water for the application of the colour and subsequent washings to remove the surplus dye. In the case of the Lyocell fibre, only one product is assessed, and, therefore, only one process is followed.

Additionally, in the case of the cotton products, the cotton growth phase shows the highest water footprint values $\left(\mathrm{m}^{3} / \mathrm{t}\right.$ ) and variability, (taken as a larger difference between the maximum and minimum). As explained, higher values in the spinning and weaving phases are related to darker colours (which require higher dyeing doses and stronger washing after dying). In contrast to the wood-based Lyocell fibres, the blue water footprint is predominant in cotton production, though grey water is also significant.

Accordingly, we focused the sustainability assessment of the jeans product on the cottonproducing stage, as this stage shows the highest water footprint within the value chain. An 
CHAPTER 4: THE WATER FOOTPRINT ASSESSMENT OF A PAIR OF JEANS: INFLUENCE OF AGRICULTURAL PRODUCTION IN CONSUMER PRODUCT'S SUSTAINABILITYINCREASING EFFICIENCY IN ETHANOL PRODUCTION: WATER FOOTPRINT AND ECONOMIC PRODUCTIVITY OF SUGARCANE ETHANOL UNDER EIGHT IRRIGATION LEVELS IN NORTH-EASTERN BRAZILTHE WATER FOOTPRINT ASSESSMENT OF A PAIR OF JEANS: INFLUENCE OF AGRICULTURAL PRODUCTION IN CONSUMER PRODUCT'S SUSTAINABILITY

analysis to evaluate the variation and impacts of this consumption was performed. The Spanish cotton production was analysed at a municipal level. Because of the significant impact of the CAP reform on cotton production (JA, 2005), the years 2005 and 2009 were selected so that the impact of CAP decoupling on the crop water footprint could be analysed. The WF per unit $\left(\mathrm{m}^{3} / \mathrm{t}\right)$ was calculated as a first step. 
CHAPTER 4: THE WATER FOOTPRINT ASSESSMENT OF A PAIR OF JEANS: INFLUENCE OF AGRICULTURAL PRODUCTION IN CONSUMER PRODUCT'S SUSTAINABILITYINCREASING EFFICIENCY IN ETHANOL PRODUCTION: WATER FOOTPRINT AND ECONOMIC PRODUCTIVITY OF SUGARCANE ETHANOL UNDER EIGHT IRRIGATION LEVELS IN NORTH-EASTERN BRAZILTHE WATER FOOTPRINT ASSESSMENT OF A PAIR OF JEANS: INFLUENCE OF AGRICULTURAL PRODUCTION IN CONSUMER PRODUCT'S SUSTAINABILITY
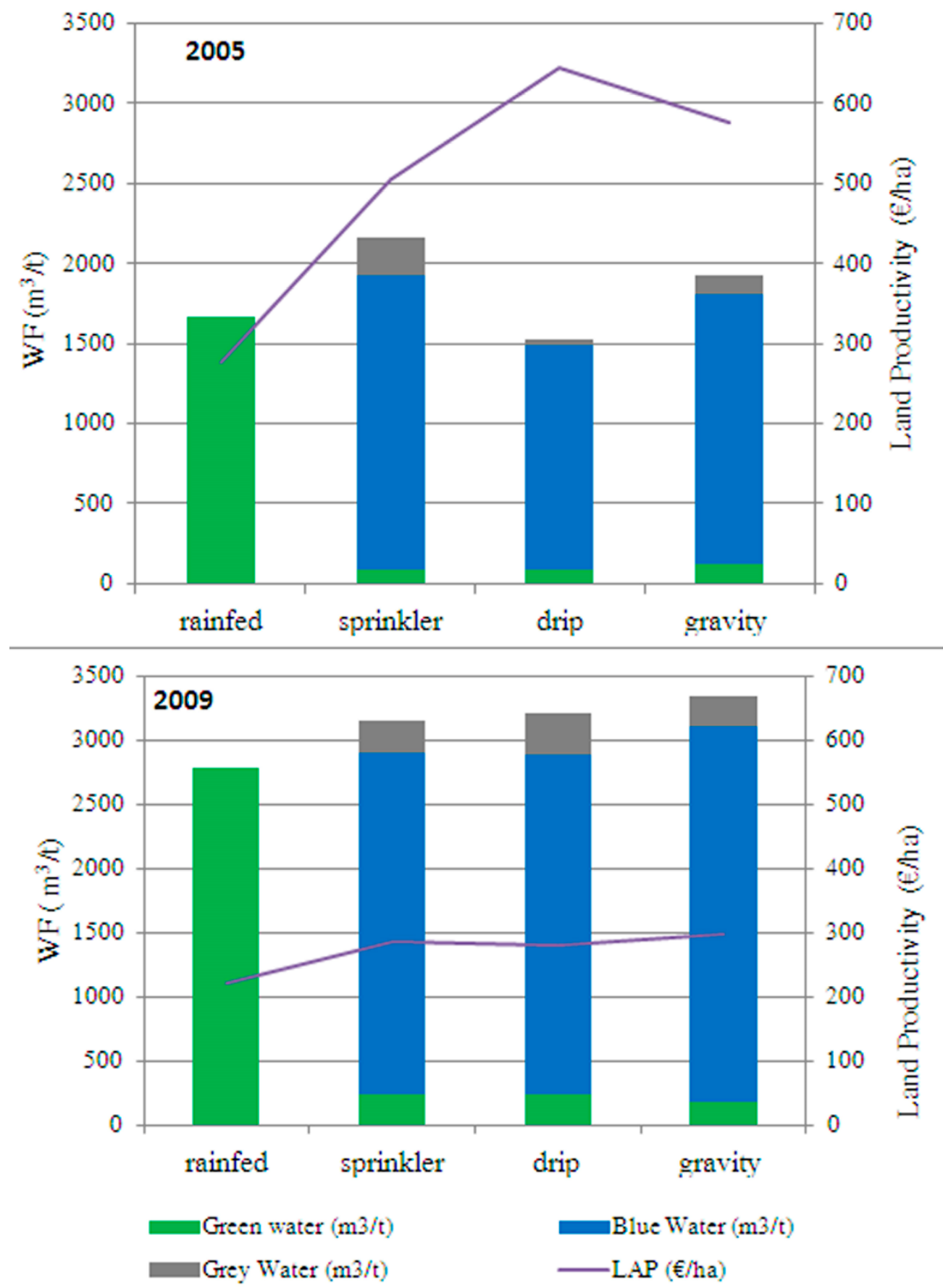

Figure 8.- Water footprint ( $\mathrm{m}^{3} / \mathrm{t}$, columns, left axis) and land productivity (LAP) (€/ha, line, right axis) per irrigation method for the years 2005 and 2009 
CHAPTER 4: THE WATER FOOTPRINT ASSESSMENT OF A PAIR OF JEANS: INFLUENCE OF AGRICULTURAL PRODUCTION IN CONSUMER PRODUCT'S SUSTAINABILITYINCREASING EFFICIENCY IN ETHANOL PRODUCTION: WATER FOOTPRINT AND ECONOMIC PRODUCTIVITY OF SUGARCANE ETHANOL UNDER EIGHT IRRIGATION LEVELS IN NORTH-EASTERN BRAZILTHE WATER FOOTPRINT ASSESSMENT OF A PAIR OF JEANS: INFLUENCE OF AGRICULTURAL PRODUCTION IN CONSUMER PRODUCT'S SUSTAINABILITY

Figure 8 shows the average water footprint $\left(\mathrm{m}^{3} / \mathrm{t}\right)$ of cotton production for the years 2005 and 2009 per irrigation method; the land productivity (euro/ha) excluding CAP's subsidies is also shown. As a consequence of the decoupling of the EU Common Agricultural Policy payments, the response of farmers to maintain profitability was to minimise variable costs, reducing irrigation and fertiliser use and altering other agricultural practices, whichresulted in lower yields, thus increasing the water footprint per unit. In the case of cotton production, a more extensive production is less efficient with regard to green and blue water consumption. Nevertheless, fertilisation and available nitrogen decreased, the yield reduction was even higher, causing the grey WF per unit to increase in 2009 compared to 2005 .

Land productivity was significantly smaller, thus less economic value is obtained per unit area, and farm profitability is threatened.

Table 4.- Average green, blue and grey WF $\left(\mathrm{m}^{3} / \mathrm{t}\right)$ and standard deviation among municipalities

\begin{tabular}{ccccccc} 
Av. Green & Av. Blue & Av. Grey & SD & SD \\
meanicipal & WF $\left(\mathrm{m}^{3} / \mathrm{t}\right)$ & $\mathrm{WF}\left(\mathrm{m}^{3} / \mathrm{t}\right)$ & $\mathrm{WF}\left(\mathrm{m}^{3} / \mathrm{t}\right)$ & $\begin{array}{c}\text { SD } \\
\text { Green WF }\end{array}$ & Blue WF & $\begin{array}{c}\text { Gunicipal } \\
\text { Grey WF }\end{array}$ \\
\hline 2005 & 133.2 & 1648.1 & 113.3 & 33.8 & 188.3 & 73.2 \\
2009 & 499.8 & 2473.4 & 228.78 & 397.6 & 581.9 & 110.5 \\
\hline
\end{tabular}

However, the relationship between the blue, green, and grey WF was reversed between 2005 and 2009: blue WF increased by 50\%, grey water increased by 101\%, and green water by $275 \%$. Variance in the WF was also significant and higher in the 2009 than in 2005 . Table 4 shows the averages obtained and standard deviations in the results per municipality for green, blue, and grey WF. Water consumption increased in variability among municipalities after the reform in 2008. There is a correlation between irrigation management and nitrogen losses. Cavero et al. (2012) studied this relationship in three semiarid areas, reporting that irrigation management was more relevant for nitrogen control than good fertilisation management. This result suggests the interrelation of blue and grey water footprints because 
CHAPTER 4: THE WATER FOOTPRINT ASSESSMENT OF A PAIR OF JEANS: INFLUENCE OF AGRICULTURAL PRODUCTION IN CONSUMER PRODUCT'S SUSTAINABILITYINCREASING EFFICIENCY IN ETHANOL PRODUCTION: WATER FOOTPRINT AND ECONOMIC PRODUCTIVITY OF SUGARCANE ETHANOL UNDER EIGHT IRRIGATION LEVELS IN NORTH-EASTERN BRAZILTHE WATER FOOTPRINT ASSESSMENT OF A PAIR OF JEANS: INFLUENCE OF AGRICULTURAL PRODUCTION IN CONSUMER PRODUCT'S SUSTAINABILITY

irrigation with lower, more frequent water applications reduces nitrogen lixiviation but increases the blue water footprint as the evaporation increases.

Regarding the overall cotton WF, Figure 9 represents the municipal cotton water footprint per year. Although the WF per unit of product $\left(\mathrm{m}^{3} / \mathrm{t}\right)$ increased, the total cotton WF in the basin decreased as the cultivated surface diminished from 85,700 ha in 2005 to 58,477 ha in 2009. The total green WF decreased from 35 to $27 \mathrm{Mm}^{3}$ and the blue WF from 455 to $197 \mathrm{Mm}^{3}$ between 2005 and 2009. The total grey water footprint decreased by more than half, from 32 to $15 \mathrm{Mm}^{3}$ during this period. 
CHAPTER 4: THE WATER FOOTPRINT ASSESSMENT OF A PAIR OF JEANS: INFLUENCE OF AGRICULTURAL PRODUCTION IN CONSUMER PRODUCT'S SUSTAINABILITYINCREASING EFFICIENCY IN ETHANOL PRODUCTION: WATER FOOTPRINT AND ECONOMIC PRODUCTIVITY OF SUGARCANE ETHANOL UNDER EIGHT IRRIGATION LEVELS IN NORTH-EASTERN BRAZILTHE WATER FOOTPRINT ASSESSMENT OF A PAIR OF JEANS: INFLUENCE OF AGRICULTURAL PRODUCTION IN CONSUMER PRODUCT'S SUSTAINABILITY

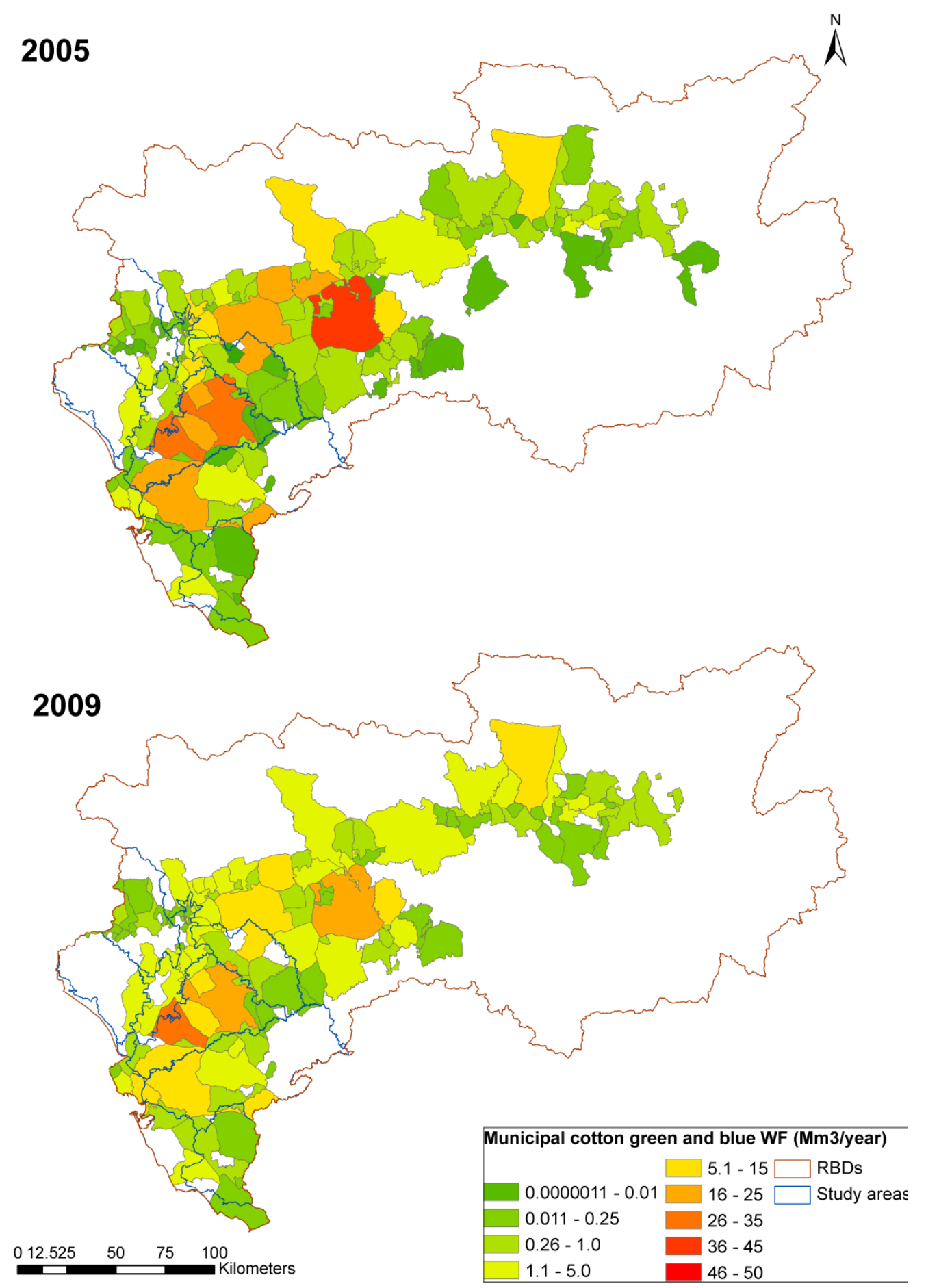

Figure 9.- Municipal cotton green and blue water footprints $\left(\mathrm{Mm}^{3} / \mathrm{y}\right)$ 
CHAPTER 4: THE WATER FOOTPRINT ASSESSMENT OF A PAIR OF JEANS: INFLUENCE OF AGRICULTURAL PRODUCTION IN CONSUMER PRODUCT'S SUSTAINABILITYINCREASING EFFICIENCY IN ETHANOL PRODUCTION: WATER FOOTPRINT AND ECONOMIC PRODUCTIVITY OF SUGARCANE ETHANOL UNDER EIGHT IRRIGATION LEVELS IN NORTH-EASTERN BRAZILTHE WATER FOOTPRINT ASSESSMENT OF A PAIR OF JEANS: INFLUENCE OF AGRICULTURAL PRODUCTION IN CONSUMER PRODUCT'S SUSTAINABILITY

The lowering of the overall WF of cotton production has contributed to lower the pressure of water resources in the basin. The setting of cotton production's WF in the basins' context was then analysed.

\subsubsection{Blue water sustainability assessment}

The theoretical water availability was set against the river flow and water stored in reservoirs (which is used for irrigation and also for urban supply, hydropower and river regulation, and environmental flow) as a comparison point. Table 5 shows the average natural runoff, environmental flow minimums, stored water, and basin outflow for the main body of the Guadalquivir River study area in 2005 and 2009 and the results for the available water, crop blue water footprint in 2005 and 2009, and WSI in 2005 and 2009.

According to RBDMP, in the Guadalquivir river basin urban water withdrawal amounts to $380.39 \mathrm{Mm}^{3} / \mathrm{y}$. Industrial water use, either directly from surface water bodies or from the urban network, represents $71.77 \mathrm{Mm}^{3} / \mathrm{y}$. Irrigation water demand (including losses and return flows) is estimated at $3495 \mathrm{Mm}^{3} / \mathrm{y}$ in the same documents. The demand for livestock adds $3.03 \mathrm{Mm}^{3} / \mathrm{y}$ (direct consumption by animals). 
CHAPTER 4: THE WATER FOOTPRINT ASSESSMENT OF A PAIR OF JEANS: INFLUENCE OF AGRICULTURAL PRODUCTION IN CONSUMER PRODUCT'S SUSTAINABILITYINCREASING EFFICIENCY IN ETHANOL PRODUCTION: WATER FOOTPRINT AND ECONOMIC PRODUCTIVITY OF SUGARCANE ETHANOL UNDER EIGHT IRRIGATION LEVELS IN NORTH-EASTERN BRAZILTHE WATER FOOTPRINT ASSESSMENT OF A PAIR OF JEANS: INFLUENCE OF AGRICULTURAL PRODUCTION IN CONSUMER PRODUCT'S SUSTAINABILITY

Table 5.- Main variables of the WSI ( $\mathrm{Mm}^{3} /$ month), WSI for the years 2005 and 2009 and main variables of the ending reservoir (Mm3/month) for the main body of the Guadalquivir river study area

\begin{tabular}{|c|c|c|c|c|c|c|c|c|c|c|c|c|c|}
\hline Month & $\begin{array}{c}\text { Av. } \\
\text { Natural } \\
\text { Runoff } \\
\left(\mathrm{Mm}^{3}\right. \\
/ \text { month })\end{array}$ & $\begin{array}{c}\text { EMF } \\
\left(\mathrm{Mm}^{3}\right. \\
/ \text { month })\end{array}$ & $\begin{array}{c}\text { Available } \\
\text { water } \\
\left(\mathrm{Mm}^{3}\right. \\
\text { /month) }\end{array}$ & $\begin{array}{c}\text { Crop } \\
\text { Blue WF } \\
2005 \\
\text { (Mm³ } \\
\text { /month) }\end{array}$ & $\begin{array}{c}\text { Crop } \\
\text { Blue WF } \\
2009 \\
\text { (Mm } \\
\text { /month) }\end{array}$ & $\begin{array}{c}\text { WSI of } \\
\text { crop } \\
\text { production } \\
2005\end{array}$ & $\begin{array}{c}\text { WSI of } \\
\text { crop } \\
\text { production } \\
2009\end{array}$ & $\begin{array}{c}\text { Available } \\
\text { stored } \\
\text { water } \\
2005 \\
\left(\mathrm{Mm}^{3}\right. \\
\text { /month) }\end{array}$ & $\begin{array}{c}\text { Available } \\
\text { Stored } \\
\text { water } 2009 \\
\left(\mathrm{Mm}^{3}\right. \\
/ \text { month })\end{array}$ & $\begin{array}{l}\text { Outflow } \\
2005 \\
\left(\mathrm{Mm}^{3}\right. \\
\text { /month) }\end{array}$ & $\begin{array}{l}\text { Outflow } \\
2009 \\
\left(\mathrm{Mm}^{3}\right. \\
\text { /month) }\end{array}$ & $\begin{array}{l}\text { Adj. } \\
\text { WSI } \\
2005\end{array}$ & $\begin{array}{l}\text { Adj. } \\
\text { WSI } \\
2009\end{array}$ \\
\hline January & 1141.75 & 21.1 & 1121 & 6.3 & 6.47 & 0.04 & 0.01 & 4240 & 898 & 47 & 100 & 0.00 & 0.01 \\
\hline February & 1172.97 & 19 & 1154 & 20.1 & 20.05 & 0.02 & 0.02 & 4222 & 1044 & 45 & 287 & 0.00 & 0.02 \\
\hline March & 921.063 & 21.1 & 900 & 73.4 & 74.28 & 0.09 & 0.08 & 4146 & 1672 & 58 & 106 & 0.02 & 0.04 \\
\hline April & 524.296 & 20.4 & 504 & 128 & 130.41 & 0.3 & 0.25 & 4139 & 1751 & 53 & 53 & 0.03 & 0.08 \\
\hline May & 292.456 & 21.1 & 271 & 228.7 & 233.39 & 0.79 & 0.84 & 3899 & 1849 & 103 & 83 & 0.06 & 0.13 \\
\hline June & 138.314 & 17.8 & 121 & 239.5 & 244.67 & 2.14 & 1.99 & 3383 & 1725 & 89 & 91 & 0.07 & 0.14 \\
\hline July & 81.5 & 18.4 & 63 & 251.3 & 256.93 & 4.17 & 3.98 & 3064 & 1491 & 105 & 78 & 0.08 & 0.17 \\
\hline August & 69.625 & 18.4 & 51 & 183 & 187.56 & 4.08 & 3.57 & 2547 & 1225 & 87 & 87 & 0.07 & 0.16 \\
\hline September & 69.625 & 17.8 & 52 & 108.8 & 110.65 & 2.56 & 2.1 & 2105 & 946 & 59 & 71 & 0.05 & 0.12 \\
\hline October & 212.611 & 19.9 & 193 & 178.2 & 106.28 & 0.42 & 0.92 & 2002 & 895 & 65 & 26 & 0.09 & 0.12 \\
\hline November & 387.637 & 19.3 & 368 & 138.7 & 95.37 & 0.3 & 0.38 & 1961 & 906 & 21 & 2 & 0.07 & 0.11 \\
\hline December & 941.074 & 21.1 & 920 & 35.4 & 0 & 0.04 & 0.04 & 1969 & 899 & 24 & 1033 & 0.02 & 0.00 \\
\hline $\begin{array}{l}\text { Total } \\
\text { Annual }\end{array}$ & 5952.9 & 235.4 & 5717.7 & 1591.4 & 1466.1 & 1.246 & 1.182 & 37675.7 & 15302.2 & 756.4 & 2017.2 & 0.048 & 0.091 \\
\hline
\end{tabular}


CHAPTER 4: THE WATER FOOTPRINT ASSESSMENT OF A PAIR OF JEANS: INFLUENCE OF AGRICULTURAL PRODUCTION IN CONSUMER PRODUCT'S SUSTAINABILITYINCREASING EFFICIENCY IN ETHANOL PRODUCTION: WATER FOOTPRINT AND ECONOMIC PRODUCTIVITY OF SUGARCANE ETHANOL UNDER EIGHT IRRIGATION LEVELS IN NORTH-EASTERN BRAZILTHE WATER FOOTPRINT ASSESSMENT OF A PAIR OF JEANS: INFLUENCE OF AGRICULTURAL PRODUCTION IN CONSUMER PRODUCT'S SUSTAINABILITY

The crop blue water footprint exceeds the naturally available water from June to September, both in 2005 and 2009, causing the WSI to exceed 1. This means that, theoretically, crop production is over-using water resources in these months and, therefore, is not meeting environmental standards. In this case, we observe that the real outflow of the study area is higher than the environmental minimum, except in November 2009. This result shows that the dam sitting at the end of this study area meets the environmental minimum requirement, at least in terms of quantity. However, the adjusted WSI, based on the available stored water reaches a maximum of 0.17 for the entire year. In fact, crops are irrigated from the water stored in the reservoirs during the previous months and years. The Guadalquivir river basin has a total storage capacity of $7,145 \mathrm{Mm}^{3}$ (this figure includes all the study areas, except the coastal area and Guadalete and Barbate river basins), and the stored water is higher than the estimated blue WF in the main body of the Guadalquivir river. It is this regulation of the river that determines availability in the basin and, therefore, the fulfilment of the environmental flow requirements and water availability in the basin. Nevertheless, the available stored water provides a reserve for several months (and not only for one month), providing carry-over resources for the next year. In its management, the River Basin District considers that demands are satisfied when the water deficit for urban use is less than $10 \%$ in a year and less than 50\% for agricultural use; these are the actual thresholds signalling water deficit in the basin. However, a significant amount of agriculture in the Guadalquivir basin is irrigated with groundwater (Salmoral et al., 2011a), which would not be included in the estimated WF. It is estimated that $30 \%$ of the total irrigation consumption is groundwater derived in the Guadalquivir RBD, with $20 \%$ in the Guadalete and Barbate RBDs (DHG, 2012; Salmoral et al., 2011a; De Stefano et al., 2012).

Table 6 provides the average cotton WF, aggregation of the total crop blue WF, natural runoff, naturally available water, average monthly available water storage, and water flow data for all the study areas for the years 2005 and 2009. The average WSI in cotton-producing months and an adjusted WSI calculated using the outflow from dams instead of the natural runoff are also shown. 
CHAPTER 4: THE WATER FOOTPRINT ASSESSMENT OF A PAIR OF JEANS: INFLUENCE OF AGRICULTURAL PRODUCTION IN CONSUMER PRODUCT'S SUSTAINABILITYINCREASING EFFICIENCY IN ETHANOL PRODUCTION: WATER FOOTPRINT AND ECONOMIC PRODUCTIVITY OF SUGARCANE ETHANOL UNDER EIGHT IRRIGATION LEVELS IN NORTH-EASTERN BRAZILTHE WATER FOOTPRINT ASSESSMENT OF A PAIR OF JEANS: INFLUENCE OF AGRICULTURAL PRODUCTION IN CONSUMER PRODUCT'S SUSTAINABILITY 
CHAPTER 4: THE WATER FOOTPRINT ASSESSMENT OF A PAIR OF JEANS: INFLUENCE OF AGRICULTURAL PRODUCTION IN CONSUMER PRODUCT'S SUSTAINABILITYINCREASING EFFICIENCY IN ETHANOL PRODUCTION: WATER FOOTPRINT AND ECONOMIC PRODUCTIVITY OF SUGARCANE ETHANOL UNDER EIGHT IRRIGATION LEVELS IN NORTH-EASTERN BRAZILTHE WATER FOOTPRINT ASSESSMENT OF A PAIR OF JEANS: INFLUENCE OF AGRICULTURAL PRODUCTION IN CONSUMER PRODUCT'S SUSTAINABILITY

Table 6.- Cotton water footprint ( $\left.\mathrm{Mm}^{3} / \mathrm{y}\right)$, blue water footprint of crop production ( $\left.\mathrm{Mm}^{3} / \mathrm{y}\right)$, total natural runoff $\left(\mathrm{Mm}^{3} / \mathrm{y}\right)$, total naturally available water $\left(\mathrm{Mm}^{3} / \mathrm{y}\right)$ average monthly WSI, average monthly water storage $\left(\mathrm{Mm}^{3} / \mathrm{month}\right)$, total outflow $\left(\mathrm{Mm}^{3} / \mathrm{y}\right)$ and average adjusted monthly WSI in cotton producing months (April-October)

\begin{tabular}{ccccccccc} 
Year & $\begin{array}{c}\text { Cotton WF } \\
\left(\mathrm{Mm}^{3} / \mathrm{y}\right)\end{array}$ & $\begin{array}{c}\text { Total Crop } \\
\text { Blue WF } \\
\left(\mathrm{Mm}^{3} / \mathrm{y}\right)\end{array}$ & $\begin{array}{c}\text { Total } \\
\text { natural } \\
\text { Runoff }\end{array}$ & $\begin{array}{c}\text { Total Available } \\
\text { water (Natural } \\
\text { Runoff }- \text { EFR, } \\
\left.\mathrm{Mm}^{3} / \mathrm{y}\right)\end{array}$ & $\begin{array}{c}\text { Average } \\
\text { monthly WSI } \\
\text { (Crop Blue } \\
\text { WF/ Available } \\
\text { water })\end{array}$ & $\begin{array}{c}\text { Monthly Stored } \\
\text { Water in Dams } \\
\left(\mathrm{Mm}^{3} \text {, Av. April - }\right. \\
\text { October })\end{array}$ & $\begin{array}{c}\text { Total Outflow } \\
\left.\text { (Mm }{ }^{3} / \mathrm{y}\right)\end{array}$ & $\begin{array}{c}\text { Average adjusted } \\
\text { monthly WSI (Crop } \\
\text { Blue WF/ Monthly } \\
\text { Outflow })\end{array}$ \\
\hline 2005 & 454.4 & 2161.2 & 1854.9 & 1704 & 4.32 & 4556.9 & 1066.9 \\
2009 & 156.9 & 2130.3 & 1854.9 & 1702.4 & 4.02 & 2829.7 & 860.31 \\
\hline
\end{tabular}


CHAPTER 4: THE WATER FOOTPRINT ASSESSMENT OF A PAIR OF JEANS: INFLUENCE OF AGRICULTURAL PRODUCTION IN CONSUMER PRODUCT'S SUSTAINABILITYINCREASING EFFICIENCY IN ETHANOL PRODUCTION: WATER FOOTPRINT AND ECONOMIC PRODUCTIVITY OF SUGARCANE ETHANOL UNDER EIGHT IRRIGATION LEVELS IN NORTH-EASTERN BRAZILTHE WATER FOOTPRINT ASSESSMENT OF A PAIR OF JEANS: INFLUENCE OF AGRICULTURAL PRODUCTION IN CONSUMER PRODUCT'S SUSTAINABILITY

Table 6 shows that the naturally available water from April to October is lower than the blue WF of the basins. The average of the WSI in these months largely exceeds the limit of the naturally available resources. If we consider the available stored water, the total available water is still lower, though the adjusted WSI is lower than the WSI based on natural flows because the basins' river dams have actually partially reversed the natural cycle. The flows in summer do not decrease as much as they would if natural conditions were maintained to satisfy water usage. Nevertheless, in both cases, the decrease of the basin's blue WF lowered the water stress, showing a smaller WSI in 2009 compared to 2005. The Guadalquivir river basin shows improved efficiency in agricultural water use, even though the irrigated area has increased (Salmoral et al., 2011a; JA, 2010).

\subsection{Discussion}

The WF methodology allows for the estimation of water resource appropriation by human activities (Hoekstra et al., 2011). For consumer products, the points of the production chain where this appropriation occurs have been identified, providing information that enables the connection between consumption and production to be defined in a clear manner. We estimated the WF of a consumer product, blue jeans, and identified fibre production as the main water-consuming phase. Significant differences were found between cotton-based products and cellulose-based fibres. Indeed, Lyocell fibre production is based on green water, which, in most cases, implies reduced impact on water resources. Moreover, as publicly stated by Lenzing Company (Shen and Patel, 2010), the origin of the wood for the cellulose is managed forests. Nevertheless, some authors discuss the trade-off between land use and green water consumption (Jewitt, 2006) and recommend the assessment of the ecosystem services provided by natural green water consumption (Willaarts et al., 2012).

In the case of cotton production, the values shown in Table 7 account for Spanish production, as estimated in this study. As a reference point, Table 7 shows the values for the main producing countries worldwide, as reported by Mekonnen and Hoekstra (2011). Turkey and Syria are included because they represent Spain's main cotton export countries. 
CHAPTER 4: THE WATER FOOTPRINT ASSESSMENT OF A PAIR OF JEANS: INFLUENCE OF AGRICULTURAL PRODUCTION IN CONSUMER PRODUCT'S SUSTAINABILITYINCREASING EFFICIENCY IN ETHANOL PRODUCTION: WATER FOOTPRINT AND ECONOMIC PRODUCTIVITY OF SUGARCANE ETHANOL UNDER EIGHT IRRIGATION LEVELS IN NORTH-EASTERN BRAZILTHE WATER FOOTPRINT ASSESSMENT OF A PAIR OF JEANS: INFLUENCE OF AGRICULTURAL PRODUCTION IN CONSUMER PRODUCT'S SUSTAINABILITY

Table 7.-Average Water Footprint of the fibres $\left(\mathrm{m}^{3} / \mathrm{t}\right)$

\begin{tabular}{|c|c|c|c|c|}
\hline & $\begin{array}{l}\text { Green } \\
\text { WF } \\
\left(\mathrm{m}^{3} / \mathrm{t}\right)\end{array}$ & $\begin{array}{l}\text { Blue } \\
\text { WF } \\
\left(\mathrm{m}^{3} / \mathrm{t}\right)\end{array}$ & $\begin{array}{l}\text { Grey } \\
\text { WF } \\
\left(\mathrm{m}^{3} / \mathrm{t}\right)\end{array}$ & $\begin{array}{l}\text { Total } \\
\text { WF } \\
\left(\mathrm{m}^{3} / \mathrm{t}\right)\end{array}$ \\
\hline China $^{(1)}$ & 3258 & 558 & 1477 & 5294 \\
\hline Spain ${ }^{(1)}$ & 902 & 4876 & 0 & 5778 \\
\hline Turkey ${ }^{(1)}$ & 1076 & 5271 & 490 & 6836 \\
\hline $\begin{array}{l}\text { United States of } \\
\text { America }\end{array}$ & 4781 & 2043 & 483 & 7307 \\
\hline Uzbekistan $^{(1)}$ & 794 & 7556 & 0 & 8350 \\
\hline Syria ${ }^{(1)}$ & 152 & 4669 & 397 & 5218 \\
\hline Cotton & 422 & 4380 & 326 & 5128 \\
\hline Lyocell fibre ${ }^{(2)}$ & 2223 & 0.58 & 57 & 2285 \\
\hline
\end{tabular}

${ }^{1}$ Source: Mekonnen et al. (2010)

${ }^{2}$ Source: Own elaboration

There are clear differences between the world's main producers, China and the USA, which rely on green water, and the remainder of the displayed countries, which have semiarid climates and where blue water plays an important role. Although the values present similarities between countries, these are averages of both regions and years. Indeed, the differences for Spain can be greater than $50 \%$ in one area. WFs exhibit a wide variability between and within regions because of the local conditions or different production technologies. Several studies have shown significant variability in the WF of an agricultural product. Salmoral et al. (2011b) and Chico et al. (2010) studied the cases of Spanish olive oil and tomato production. Mekonnen and Hoekstra (2011) estimated worldwide per region and country green, blue and grey WF of an ample selection of crops and animal products. Ridoutt et al. (2011) showed the differences among production systems in the livestock sector.

Pfister et al. (2009) analysed the variation of cotton water consumption, reporting that the variation is greater within a country (for the main producing countries) than among 
CHAPTER 4: THE WATER FOOTPRINT ASSESSMENT OF A PAIR OF JEANS: INFLUENCE OF AGRICULTURAL PRODUCTION IN CONSUMER PRODUCT'S SUSTAINABILITYINCREASING EFFICIENCY IN ETHANOL PRODUCTION: WATER FOOTPRINT AND ECONOMIC PRODUCTIVITY OF SUGARCANE ETHANOL UNDER EIGHT IRRIGATION LEVELS IN NORTH-EASTERN BRAZILTHE WATER FOOTPRINT ASSESSMENT OF A PAIR OF JEANS: INFLUENCE OF AGRICULTURAL PRODUCTION IN CONSUMER PRODUCT'S SUSTAINABILITY

countries. A river basin or even a smaller unit is better assessment scale for the water footprint of a product. In the case of specific consumer products, the spatial and temporal differences in WF make it necessary to study water consumption at the lowest possible scale to provide accurate estimations for the product value chain.

In their study of the water footprint of the Guadalquivir river, Salmoral et al. (2011b) report that the total blue WF represents $9 \%$ of the precipitation falling in the basin. For a hydrologically normal year (2003), these authors estimated the total runoff as $6,088 \mathrm{Mm}^{3} / \mathrm{y}$, similar to the average data used herein, and their estimates of the agricultural blue water footprint in the Guadalquivir basin were $2290 \mathrm{Mm}^{3}$ for 2003 and $1470 \mathrm{Mm}^{3}$ for 2008. These values are similar to those reported in the present study because we based our calculation on their methodology and adjusted the available irrigation water to the crop type and type of hydrological year. The data reported in Table 4 correspond to a fraction of the basin. Using a methodology based on the RBDMP's water allocations per crop and data from 2004, Montesinos et al. (2011) estimated the blue WF of the Guadalquivir basin to be $1,755 \mathrm{Mm}^{3}$.

The apparel industry procures its raw materials from a variety of sources, thus the water footprint of its products may vary significantly. This forms the core of the industries' environmental responsibility: learning how suppliers can pollute less and become more efficient. Field results are more variable than the country and regional averages, and this offers opportunities for companies that intend to lower the environmental pressure of their products. A company's logical response could be to select providers that are more efficient in water use by taking advantages of agronomical practices and technology that significantly yield the best results. Indeed, the agricultural practices could bear improvements with regard to the environment. Hurtado et al. (2011) estimated the nitrogen losses from the lower Guadalquivir area with artificial drainage under cotton cultivation in 2003, reporting that 6$8 \%$ of applied nitrogen is lost and suggesting inadequate nitrogen management for this typical fertilisation behaviour. Santos et al. (2010) studied an irrigation scheme in the basin in detail and report a varying acceptance of the recommendations from the irrigation advisory service by farmers, leading to varying efficiencies in irrigation performance, both over- and under-satisfying crop water requirements. 
CHAPTER 4: THE WATER FOOTPRINT ASSESSMENT OF A PAIR OF JEANS: INFLUENCE OF AGRICULTURAL PRODUCTION IN CONSUMER PRODUCT'S SUSTAINABILITYINCREASING EFFICIENCY IN ETHANOL PRODUCTION: WATER FOOTPRINT AND ECONOMIC PRODUCTIVITY OF SUGARCANE ETHANOL UNDER EIGHT IRRIGATION LEVELS IN NORTH-EASTERN BRAZILTHE WATER FOOTPRINT ASSESSMENT OF A PAIR OF JEANS: INFLUENCE OF AGRICULTURAL PRODUCTION IN CONSUMER PRODUCT'S SUSTAINABILITY

Lorite et al. (2012) observed that cotton farmers irrigated between 29 and 57\% below the recommended amount in the 2006 and 2007 seasons, emphasising the change in CAP payments, irrigation water availability, and differences in the response to deficit irrigation between crops. In a detailed study on Andalusian cotton production, Arriaza (2008) reported decreases of $55 \%$, and $67 \%$ in fertiliser use, with the farmers declaring their intention of also reducing pesticide use. Wheat, sunflower, citrus, and olive tree cultivation have substituted for cotton. The number of cotton producers decreased from 9445 in 2004/05 to 6979 in 2007 (JA, 2008), and the working hours needed by the crop decreased by $20 \%$ between 2003 2006 and 2007 (García-Vila et al., 2008).

However, due to a change in the CAP's support to EU cotton production, the total WF $\left(\mathrm{Mm}^{3}\right)$ decreased by 65\% because the cultivated surface decreased more than the increase in WF per ton produced. Giannocaro and Berbel (2011) report that the response to a reform of CAP payments is influenced by the geographical situation of the farm. In the case of Andalusia (contrary to the overall EU-wide result). Their survey shows that most of the farmers would modify their water use if the CAP payments were to be removed, both with regard to increasing and decreasing usage. Farming practices respond to incentives, including the price obtained per product and CAP payments. Accordingly, the production methods changed significantly as the subsidy's incentive disappeared.

Nevertheless, within a context of higher product prices, the response of cotton producers is to intensify production. As the price paid for raw cotton increased by $90 \%$, the cultivated surface and yields obtained increased by 14 and 50\% in the years 2008-2010, respectively (MAGRAMA, 2012). In the analysis made for cotton production in Spain, it was shown that the extensification of production has led to a higher WF per ton produced (average of $50 \%$ increase) and lower harvest value, which is partially compensated for by the CAP's subsidy. However, the environmental consequence of this is ambiguous. When production was less intensive, the pressure on water resources per unit increased at the individual level because production was less efficient; however, the overall pressure decreased because a smaller surface area was cultivated. There is a need to move toward sustainable intensification of agricultural systems to restore systems and increase the efficiency of resource use (natural/human/economic). 
CHAPTER 4: THE WATER FOOTPRINT ASSESSMENT OF A PAIR OF JEANS: INFLUENCE OF AGRICULTURAL PRODUCTION IN CONSUMER PRODUCT'S SUSTAINABILITYINCREASING EFFICIENCY IN ETHANOL PRODUCTION: WATER FOOTPRINT AND ECONOMIC PRODUCTIVITY OF SUGARCANE ETHANOL UNDER EIGHT IRRIGATION LEVELS IN NORTH-EASTERN BRAZILTHE WATER FOOTPRINT ASSESSMENT OF A PAIR OF JEANS: INFLUENCE OF AGRICULTURAL PRODUCTION IN CONSUMER PRODUCT'S SUSTAINABILITY

This is a very important factor to consider when attempting to develop more environmentally friendly products, as it may impact the effectiveness of the efforts taken. Companies aiming to generate products with less environmental pressure could achieve products with less WF; however, if enough incentives are provided, the overall water consumption and total amount of agrochemicals reaching the water bodies may increase. Another possibility is that the company's efforts do not ameliorate the environmental situation of a river basin if their influence is restricted to a product. This could be the case in the Guadalquivir basin where cotton represents only 7\% of the basin's blue WF. The overall state of a specific basin may be out of the scope of a specific company, as the status depends on the product's relevance to the basin's water issues. In this case, more extensive cotton production has not substantially reduced the WF of the study basin.

Our results show that measuring only WF per unit is not sufficient to evaluate a product's sustainable use of resources. Because resources are shared by many uses and production chains, independently of the performance of a specific product, the entire basin may behave worse or better than a particular set of products. The WF per unit of a product has to be considered within the relevant context to be meaningful and relevant to policy. A more intensive production will generally be accompanied by a reduced WF. However, as WF is a relative indicator, it does not reflect the overall load on the resources in the river basin.

Because the production context has a high relevance, there is a need for a second phase of analysis that includes an impact assessment, and there is a need to weigh the obtained water consumption with water stress coefficients to make the results among sites comparable (Ridoutt and Pfister, 2012). This was reflected in the calculated WSI. However, as the river basin studied is highly regulated, calculating the available water from the natural runoff was not completely informative with regard to the existing water availability, even after the environmental flows were taken into account. In regulated rivers, this existing infrastructure conditions the river functioning and enables the maintenance of the ecological functions. To highlight this, we compared both the available water stored in the study years and the measured outflow in the endpoints of the study areas with the EFR and water naturally available from runoff. This allowed us to also include very specific temporal and spatial variations in the WSI. In principle, the stored water is greater than the agricultural demand, 
CHAPTER 4: THE WATER FOOTPRINT ASSESSMENT OF A PAIR OF JEANS: INFLUENCE OF AGRICULTURAL PRODUCTION IN CONSUMER PRODUCT'S SUSTAINABILITYINCREASING EFFICIENCY IN ETHANOL PRODUCTION: WATER FOOTPRINT AND ECONOMIC PRODUCTIVITY OF SUGARCANE ETHANOL UNDER EIGHT IRRIGATION LEVELS IN NORTH-EASTERN BRAZILTHE WATER FOOTPRINT ASSESSMENT OF A PAIR OF JEANS: INFLUENCE OF AGRICULTURAL PRODUCTION IN CONSUMER PRODUCT'S SUSTAINABILITY

but the river flows do not always satisfy EFR. Urban and energy users also condition the use of water for irrigation. Institutional arrangements (for example, drought management plans, insurance, or water banks) and technological solutions (for example, reservoirs, irrigation technologies, or water re-use) introduce flexibility and possibilities for the management of resources, allowing human activities to increase their use of natural resources while minimising its impacts. It is very difficult to incorporate such factors as indicators, and these factors need a deeper assessment, and high-resolution information (Berger and Finkbeiner, 2010).

\subsection{Conclusions}

WF accounting is a helpful tool for the identification of relevant water consumption and pollution in the value chain, and significant differences are found between product categories. Cellulose-based Lyocell fibre has a notably lower water consumption than cotton fibres, on average $1384,34.5$, and $35.3 \mathrm{~m}^{3} / \mathrm{t}$ as opposed to 263,2767 , and $203 \mathrm{~m}^{3} / \mathrm{t}$ for green, blue, and grey water, respectively. WF accounting is also useful to analyse water use at a disaggregate level, allowing its connection with production and consumption, both spatially and temporally, and the study of the drivers and trends of water use. However, WF accounting results have to be interpreted with caution, as they need to be considered within the appropriate context to be meaningful. A second phase of sustainability assessment is needed to study the environmental impact and socioeconomic context of this consumption.

Independently of its relative weight in a region, the impact of specific agricultural production is determined by the aggregate response of many activities. Addressing the minimum WF per unit $\left(\mathrm{m}^{3} / \mathrm{t}\right)$ may only partially affect the river basin status. Price incentives and public policies affect the response of farmers, but the collective result of all users is the one that influences the sustainability of water consumption in a region. These incentives may heavily affect the water consumption of a specific production system and need to be taken into account by companies trying to improve their water management. Although some of these incentives may fall out of the scope of a particular company, such as those originating 
CHAPTER 4: THE WATER FOOTPRINT ASSESSMENT OF A PAIR OF JEANS: INFLUENCE OF AGRICULTURAL PRODUCTION IN CONSUMER PRODUCT'S SUSTAINABILITYINCREASING EFFICIENCY IN ETHANOL PRODUCTION: WATER FOOTPRINT AND ECONOMIC PRODUCTIVITY OF SUGARCANE ETHANOL UNDER EIGHT IRRIGATION LEVELS IN NORTH-EASTERN BRAZILTHE WATER FOOTPRINT ASSESSMENT OF A PAIR OF JEANS: INFLUENCE OF AGRICULTURAL PRODUCTION IN CONSUMER PRODUCT'S SUSTAINABILITY

from the Common Agricultural Policy, which only influence EU farmers, a good understanding of them may improve the effectiveness of a company's efforts to achieve environmentally friendlier products.

Weighing WFs with stress indicators assists in defining them with regard to the local water scarcity and in comparing between years and basins. Nevertheless, the definition of water scarcity is complex, and technological and institutional tools may also be crucial for an area to manage its resources efficiently and prioritise the uses that it considers most important. All these factors are difficult to combine into a single indicator, and broader studies of the area are needed for a complete understanding of the impact of water use.

\section{Acknowledgements}

This work was done with the assistance of Inmaculada Del Moral (Aitex), Jorge Solano and Antonio Almela (Tejidos Royo) and Lenzing Gruppe, producers of Tencell Fibre (Lyocell Fibre). 


\section{ECONOMIC AND ECOSYSTEM SERVICES VALUATION OF LAND AND WATER USE IN BRAZILIAN SUGARCANE UNDER EVOLVING MANAGEMENT PRACTICES AND LAND USE CHANGE}

\subsection{Introduction}

Brazil has become a global player in agricultural production and trade, contributing significantly to global food and water security (Dalin et al, 2012). In addition to this, increased national and international demand for biofuel and sugar has boosted sugarcane production in the country over the last decades (Filoso, 2015), making it the world's leading producer of sugarcane and second largest producer of bio-ethanol. A combination of policies promoting demand, as well as institutional arrangements promoting supply have resulted in continuous cultivation area and productivity increases (Martinelli and Filoso, 2012; Furtado et al., 2011). The State of São Paulo (SP) has one of the country's most important agricultural regions and is the largest sugarcane producer in Brazil (IBGE, 2016). State production has continued to grow from 189.04 million tons in 2000 up to 401.33 million tons in 2014 (IBGE, 2017). The expansion of sugarcane has led to large areas being dedicated to this crop. Sugarcane cultivation represented $67 \%$ of the state cultivated area in 2014 (ibid).

While this development has brought socio-economic benefits (Filoso, 2015), it has also led to environmental and social challenges (Lapola et al., 2011; Martinelli and Filoso, 2012). During the 1990's and early 2000's, the focus has been placed on the direct and indirect effects of sugarcane expansion, pushing pasture areas and cattle raising beyond the agricultural frontier (Filoso, 2015). According to Sparovek et al. (2007), in SP state sugarcane expanded mostly over existing pastures and annual crops, without causing any direct deforestation on natural areas (Mata Atlantica, Cerrado and Cerradao). In SP, the link between decreased deforestation and pasture (and crop) intensification would point to a forest transition process (Lira et al., 2012). There are signs that the land use succession from deforestation, to large scale cattle ranching, extensive crop production and finally crop intensification of the more profitable productions with reforestation processes is advanced in the state (Farinacci et al., 2013).

In SP, sugarcane fields are set on fire to ease manual harvesting. As a result, there were concerns about the medical, toxicological and environmental impacts (Goldemberg $e t$ 
CHAPTER 5: ECONOMIC AND ECOSYSTEM SERVICES VALUATION OF LAND

AND WATER USE IN BRAZILIAN SUGARCANE UNDER EVOLVING

MANAGEMENT PRACTICES AND LAND USE CHANGEINCREASING

EFFICIENCY IN ETHANOL PRODUCTION: WATER FOOTPRINT AND

ECONOMIC PRODUCTIVITY OF SUGARCANE ETHANOL UNDER EIGHT

IRRIGATION LEVELS IN NORTH-EASTERN BRAZILTHE WATER FOOTPRINT

ASSESSMENT OF A PAIR OF JEANS: INFLUENCE OF AGRICULTURAL PRODUCTION IN CONSUMER PRODUCT'S SUSTAINABILITY

al., 2008; Martinelli et al., 2011). The alternative is sugarcane mechanical harvesting. The sugarcane sector implemented a state regulation on sugarcane burning (Etanol verde, Environment secretary of São Paulo state, 2002), building a certification system together with the State Environment Department and even moving beyond the proposed goals (Rudorff et al., 2010). Through this commitment, the sugar-ethanol sector pledged to gradually phase out burning by 2014 in more suitable areas for mechanical harvesting and by 2017 in the remaining areas. Rudorff et al. (2010), regarded the commitment as successful by the year 2008 when over $50 \%$ of the areas suitable for mechanization had already abandoned straw mechanization. In $201272.6 \%$ of sugarcane harvested area in SP state was mechanically harvested (CANASAT, 2017). Such change had effects both at the local but also river basin scale (Merten and Minella, 2016).

At the field level, mechanical harvesting leaves a higher amount of straw in the field than manual harvesting with burning, protecting the soil against raindrop impact and slowing runoff. The change in sugarcane harvesting, from straw burning to mechanical harvesting also has effects on soil carbon and nutrient balance (Martinelli et al., 2011) and soil physical properties, which results in lower erosion rates and higher infiltration rates (Tosto et al. 2010).

On the river basin scale, there may be further implications of sugarcane expansion. As part of its commitment, the sector also pledged to protect natural riparian areas and to introduce measures to reduce erosion. Areas where mechanization is difficult, like more steep areas in the south west of the river basin, show relatively lower productivities which subsequently leads to land abandonment and restoration of natural areas (Rudorff et al., 2010).

Reported values of sugarcane erosion rates show a great variability depending on rainfall, slope, management and soil type (Filoso et al., 2015). Literature reports average values of 20 $\mathrm{t} \mathrm{ha}^{-1}$ for mechanical harvesting, and maximum values of $279 \mathrm{t} \mathrm{ha}^{-1}$ (Sparovek and Schnug, 2001). Martins Filho et al. (2009) report values between 4 to $9 \mathrm{t} \mathrm{ha}^{-1}$ for manual harvesting with burning and $2 \mathrm{t} \mathrm{ha}^{-1}$ for mechanical harvesting. De Andrade (2010) in a study carried out in the Araras municipality in the Mogí-Guacu Pardo (MGP) river MGP river basin 
CHAPTER 5: ECONOMIC AND ECOSYSTEM SERVICES VALUATION OF LAND

AND WATER USE IN BRAZILIAN SUGARCANE UNDER EVOLVING

MANAGEMENT PRACTICES AND LAND USE CHANGEINCREASING EFFICIENCY IN ETHANOL PRODUCTION: WATER FOOTPRINT AND ECONOMIC PRODUCTIVITY OF SUGARCANE ETHANOL UNDER EIGHT IRRIGATION LEVELS IN NORTH-EASTERN BRAZILTHE WATER FOOTPRINT ASSESSMENT OF A PAIR OF JEANS: INFLUENCE OF AGRICULTURAL PRODUCTION IN CONSUMER PRODUCT'S SUSTAINABILITY

reports average values of $4 \mathrm{t} \mathrm{ha}^{-1}$ for mechanical harvesting and $14 \mathrm{t} \mathrm{ha} \mathrm{h}^{-1}$. for manual harvesting with burning. Cantalice et al.(2009) report ranges of 2.36 to $49.97 \mathrm{t} \mathrm{ha}^{-1}$ according to the degree of straw covering in the field after harvest (straw cover in manual system can be around $10-40 \%$ and in mechanical system the range from $60-90 \%$ of the surface) in Recife. They also report increases of $10 \%$ when moving from areas with $5 \%$ slope to $15 \%$.

To evaluate the appropriation of water resources for human activities, Hoekstra et al. (2003) introduced the water footprint concept. The water footprint can be defined as the direct and indirect water consumption needed to produce goods and services. In terms of water quantity, it considers blue and green water consumption (Hoekstra et al., 2011). Green water consumption is the part of rainwater stored in the soil and consumed by vegetation. The methodology can serve as a diagnosis tool to understand the different water users in a river basin (Hoekstra et al., 2011) and their implications in environmental or economic terms (Dumont et al., 2013).

Assessment of blue water resources is well described in the work by Hoekstra et al., (2011), Dumont et al., (2013) or Mekonnen et al.(2014). However, assessments of the green water footprint are still undertaken using limiting assumptions (Willaarts et al., 2012; Mekonnen et al., 2014; CTA, 2015). Green water is generally considered to have a lower opportunity cost in comparison to blue water, since it cannot be easily allocated to other socio-economic uses (Garrido et al., 2010). But green water is closely linked to the existing land use, and in this regard its opportunity cost will be at least that of the land use. Moreover, the hydrological cycle in a specific basin can be conditioned by the existing land uses (Locatelli and Vignola, 2009).

Van Oel and Hoekstra, (2012) in their assessment of the WF of paper products, mention that the analysis of human appropriation of ET by forests, could be complemented by the consideration of ES value. Schyns et al., (2017) evaluated the WF of wood production globally and used the ES value concept to allocate forest ET between wood and the rest of ES provided. Vanham (2016c) analysed the relation of WF and ES concepts, arguing for the need to relate better both concepts. Tadeu (2014) made an analysis of the growth of 
CHAPTER 5: ECONOMIC AND ECOSYSTEM SERVICES VALUATION OF LAND

AND WATER USE IN BRAZILIAN SUGARCANE UNDER EVOLVING

MANAGEMENT PRACTICES AND LAND USE CHANGEINCREASING

EFFICIENCY IN ETHANOL PRODUCTION: WATER FOOTPRINT AND

ECONOMIC PRODUCTIVITY OF SUGARCANE ETHANOL UNDER EIGHT

IRRIGATION LEVELS IN NORTH-EASTERN BRAZILTHE WATER FOOTPRINT

ASSESSMENT OF A PAIR OF JEANS: INFLUENCE OF AGRICULTURAL PRODUCTION IN CONSUMER PRODUCT'S SUSTAINABILITY

eucalyptus plantations over pasture and compared both uses to natural areas in terms of water balance, water footprint and ecosystem services (ES). She points out to the higher ET and lower water provisioning service of eucalyptus plantations in comparison to pasture and tropical rainforest in the coastal region of São Paulo.

Moreover, since water footprint is the relation of water consumption and amount of good or service obtained, it may serve as an indicator of physical productivity of water consumption, or the efficiency of resource use. The term efficiency may have multiple meanings, depending on the concepts (variables) used in its calculation (Foster and Perry, 2009). By introducing the value of the product obtained, the indicator is transformed into a gross measure of economic productivity of water consumption. In such context, it has been termed "water apparent productivity" by Garrido et al., 2010 or water economic productivity by Chouchane et al. (2015). It then reflects the market value associated to water use by means of using it for obtaining a certain product. The indicator can then inform the discussion on water allocation between different uses.

Green water comprises a phase of the hydrological cycle connected to the rest of it through subsurface and/or surface runoff. Different crops have different evapotranspiration rates, which will affect differently the partitioning between infiltration/runoff, increase soil moisture and affect the relation between surface-subsurface flow (Salemi et al., 2013). Related to these variables, natural processes like erosion and sediment transportation, nutrient leaching and agrochemicals accumulation are affected. Such effects, aggregated over the basin can modify peak and low flow levels and water quality (Locatelli and Vignola., 2009). The aggregated effect of land uses over the hydrological cycle in an area will determine the net positive or negative effects of green water use.

As ecosystem services valuation is the measure of the economic benefits from the environmental functions linked to an activity. Ecosystem services are defined as "benefits people obtain from ecosystems" (MEA, 2002), but the concept has also been broadened to apply to other land uses such as agriculture (Power, 2010). Based on this notion, the valuation of the benefits provided by ES has been proposed as a tool for the recognition and inclusion 
CHAPTER 5: ECONOMIC AND ECOSYSTEM SERVICES VALUATION OF LAND

AND WATER USE IN BRAZILIAN SUGARCANE UNDER EVOLVING

MANAGEMENT PRACTICES AND LAND USE CHANGEINCREASING

EFFICIENCY IN ETHANOL PRODUCTION: WATER FOOTPRINT AND

ECONOMIC PRODUCTIVITY OF SUGARCANE ETHANOL UNDER EIGHT

IRRIGATION LEVELS IN NORTH-EASTERN BRAZILTHE WATER FOOTPRINT

ASSESSMENT OF A PAIR OF JEANS: INFLUENCE OF AGRICULTURAL PRODUCTION IN CONSUMER PRODUCT'S SUSTAINABILITY

of these benefits into the economic system and decision-making (Constanza et al., 2014). This allows for the inclusion and valuation of unaccounted-for effects of land use, and consider the interactions at a landscape level (Gordon et al., 2010). Agriculture and forestry are multifunctional activities with direct and indirect effects on natural processes and various social groups. These processes and effects often lead to trade-offs between provision and regulation or supporting services (Bryan, 2013). Therefore, a valuation of water resources will be more complete if these relations are taken into account. In short, there is a necessity to include not only the physical efficiency and water economic valuation but also analyses the ES provided by them to provide a broader perspective on the social gains from water use.

Building upon the approach of Tadeu et al. (2014), this paper addresses the effects of sugarcane developments and the land use changes occurred in the basin on the efficiency of water use. The analysis is performed for sugarcane and for the main land uses for the period 2000-2102 in the Mogi-Guaçu Pardo river basin in São Paulo state. The aim of the present study is to evaluate the sugarcane water productivity in relation to the main land uses in terms of economic value and ES generated. We integrate the concept of ES in the Water Footprint Assessment to evaluate water use in sugarcane in market terms and consider potential externalities associated to land and water use. By introducing this concept into the WF analysis, we add the benefits and costs of land use linked to specific uses as part of the hydrological cycle.

\subsection{Materials and methods}

\subsubsection{Study area}

The study region is the São Paulo state segment of the MGP river basin (see Figure 10). 
CHAPTER 5: ECONOMIC AND ECOSYSTEM SERVICES VALUATION OF LAND AND WATER USE IN BRAZILIAN SUGARCANE UNDER EVOLVING MANAGEMENT PRACTICES AND LAND USE CHANGEINCREASING EFFICIENCY IN ETHANOL PRODUCTION: WATER FOOTPRINT AND ECONOMIC PRODUCTIVITY OF SUGARCANE ETHANOL UNDER EIGHT IRRIGATION LEVELS IN NORTH-EASTERN BRAZILTHE WATER FOOTPRINT ASSESSMENT OF A PAIR OF JEANS: INFLUENCE OF AGRICULTURAL PRODUCTION IN CONSUMER PRODUCT'S SUSTAINABILITY

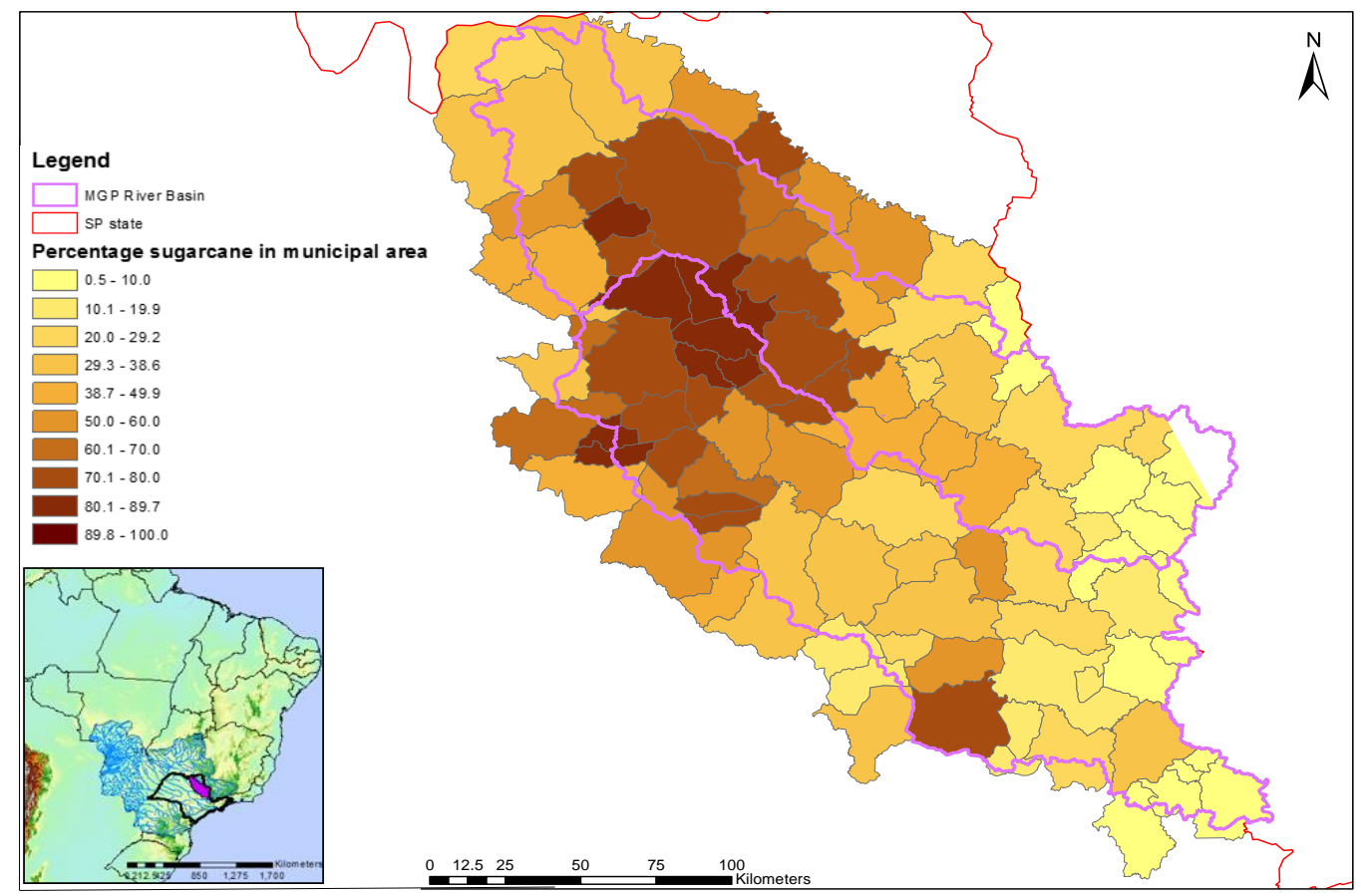

Figure 10.- Study river basin in Brazil and percentage sugarcane area in the municipal area

The study covers the period 2000 - 2012. Data for 2000-2012 on area and land use per municipality were obtained from the database of the Institute of Agricultural Economy (IEA) of the São Paulo State Agriculture Secretariat database (IEA, 2016). Data on crop and animal products production per municipality and year for the period 2000-2012 were obtained from the IEA database (IEA, 2014a). 
CHAPTER 5: ECONOMIC AND ECOSYSTEM SERVICES VALUATION OF LAND AND WATER USE IN BRAZILIAN SUGARCANE UNDER EVOLVING MANAGEMENT PRACTICES AND LAND USE CHANGEINCREASING EFFICIENCY IN ETHANOL PRODUCTION: WATER FOOTPRINT AND ECONOMIC PRODUCTIVITY OF SUGARCANE ETHANOL UNDER EIGHT IRRIGATION LEVELS IN NORTH-EASTERN BRAZILTHE WATER FOOTPRINT ASSESSMENT OF A PAIR OF JEANS: INFLUENCE OF AGRICULTURAL PRODUCTION IN CONSUMER PRODUCT'S SUSTAINABILITY

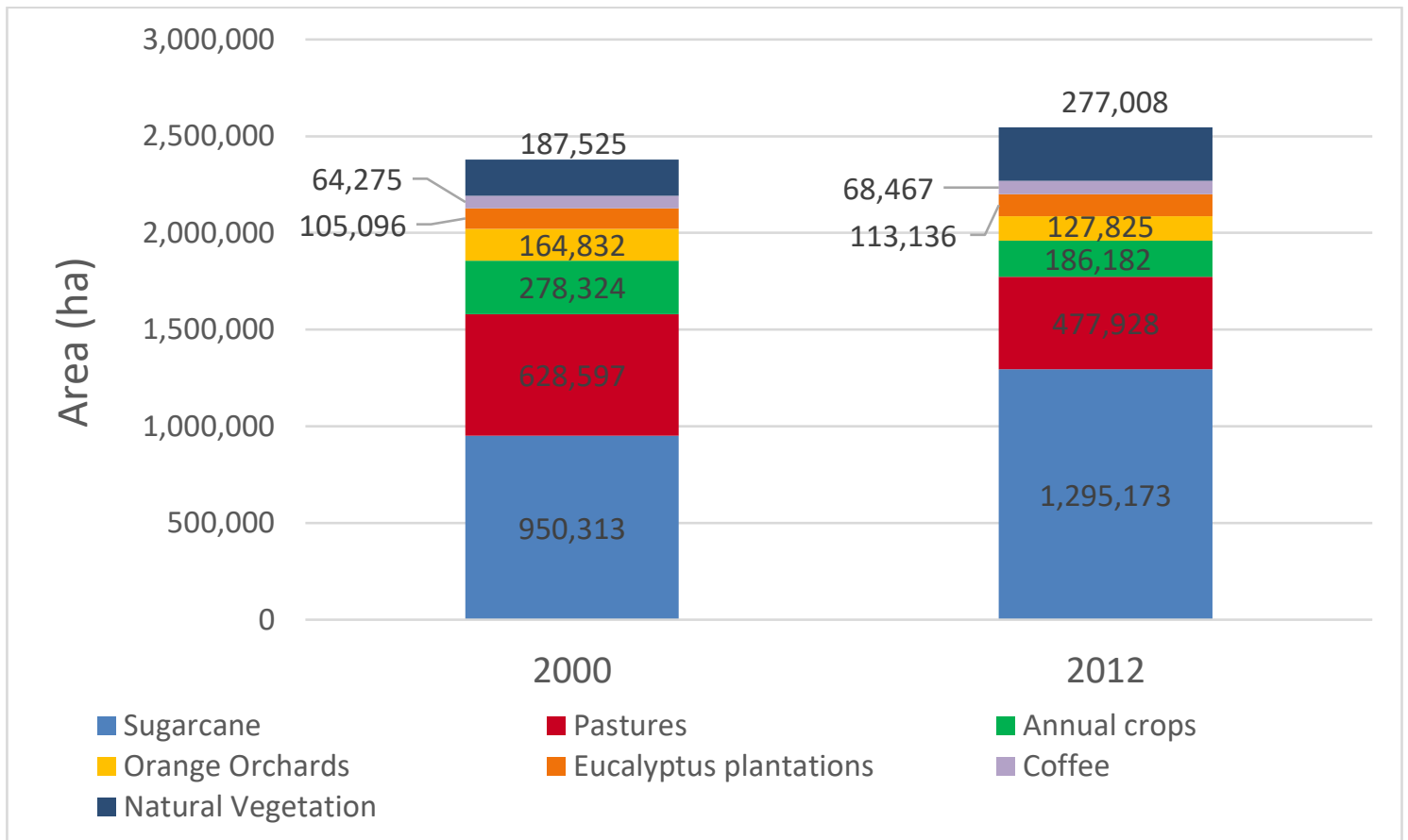

Figure 11.- Average areas (ha) and percentage of basin area per land use type for the years 2000 and 2012

In the MGP river basin, sugarcane is the main land use, followed by pastures, annual crops and to a lesser extent natural areas (Figure 11). Agriculture is concentrated mostly in the northern, part of the basin, where municipalities dedicate $60-80 \%$ of their area to sugarcane, the remaining area being composed by annual crops (corn, soybeans, beans and sorghum, including a small share of irrigated area), orange orchards and pastures. In the study period (2000-2012), sugarcane area has grown 36\% at basin level, whereas pasture areas have diminished by $23 \%$ and annual crops (corn, sorghum, soybeans and groundnuts) by $33 \%$. With respect to annual crops, in this region two harvests per year can be achieved, the most common succession being corn followed by soybean, but over the period of investigation second harvests have decreased from $50 \%$ to $38 \%$. This has been the main land use change in the MGP between 2000 and 2012. More steep areas to the East of the basin present a varied mosaic of pastures, natural areas, eucalyptus and coffee plantations. Eucalyptus and coffee plantations have slightly grown in area, $6 \%$ and $7 \%$ respectively. Orange orchards have declined at the basin level by a $22 \%$. The share of natural land has increased, from $7.7 \%$ 
CHAPTER 5: ECONOMIC AND ECOSYSTEM SERVICES VALUATION OF LAND

AND WATER USE IN BRAZILIAN SUGARCANE UNDER EVOLVING

MANAGEMENT PRACTICES AND LAND USE CHANGEINCREASING EFFICIENCY IN ETHANOL PRODUCTION: WATER FOOTPRINT AND ECONOMIC PRODUCTIVITY OF SUGARCANE ETHANOL UNDER EIGHT IRRIGATION LEVELS IN NORTH-EASTERN BRAZILTHE WATER FOOTPRINT ASSESSMENT OF A PAIR OF JEANS: INFLUENCE OF AGRICULTURAL PRODUCTION IN CONSUMER PRODUCT'S SUSTAINABILITY

to $10.6 \%$, i.e. grew from 187,237 ha in 2000 to 277,008 ha in 2012 (IEA, 2015). The basin encompasses the two most relevant biomes of south-eastern Brazil, the tropical humid forest (the so-called Mata Atlantica) and the savanna-like areas with a marked dry season (locally called Cerrado), which in some places is substituted by semi-deciduous dry land forests (also called Cerradao). The growth in the natural land was in Mata areas up to a $86 \%$, while Cerrado areas have remained stable and Cerradao increased from 50,205 ha to 56,690 ha from 2000 to 2012.

As for the development of mechanical harvesting, in the MGP river basin, a total of 881,529 ha was manually harvested in the year $2000-93 \%$ of the total sugarcane area whereas in the year 2012 this number decreased to 394,674 ha, or 30\%. Data for municipal share of manual or mechanical harvesting was obtained from the CANASAT project (Aguiar et al., 2011). In the year 200087 of the 90 municipalities burned more than $60 \%$ of their sugarcane area, in the year 2012 only 6 municipalities still maintained this practice in over $60 \%$ of their area.

\subsubsection{Methodology and data}

The Water Footprint Assessment (WFA) framework developed by Hoekstra et al. (2011) provides the conceptual basis for the analysis carried out here (Figure 12). The aim of the present study is to evaluate the sugarcane water productivity in relation to the main land uses in terms of economic value and ES generated. This pertains to the sustainability assessment phase of WFA (Hoekstra et al., 2011). Environmental and social sustainability are excluded from the analysis. In the accounting phase, the green and blue water footprint of the selected land uses in the basin are calculated, as well as the value of the ES generated for each land use type. In the sustainability assessment phase, the efficiency of water use for sugarcane production is assessed by comparing the economic and ES value generated and relating it to the main land uses of the basin. This is achieved through the evaluation of the water apparent productivity $\left(\$ \mathrm{~m}^{-3}\right)$ and complementing it with the results of the ES valuation per unit of land and water. 
CHAPTER 5: ECONOMIC AND ECOSYSTEM SERVICES VALUATION OF LAND

AND WATER USE IN BRAZILIAN SUGARCANE UNDER EVOLVING MANAGEMENT PRACTICES AND LAND USE CHANGEINCREASING EFFICIENCY IN ETHANOL PRODUCTION: WATER FOOTPRINT AND ECONOMIC PRODUCTIVITY OF SUGARCANE ETHANOL UNDER EIGHT IRRIGATION LEVELS IN NORTH-EASTERN BRAZILTHE WATER FOOTPRINT ASSESSMENT OF A PAIR OF JEANS: INFLUENCE OF AGRICULTURAL PRODUCTION IN CONSUMER PRODUCT'S SUSTAINABILITY

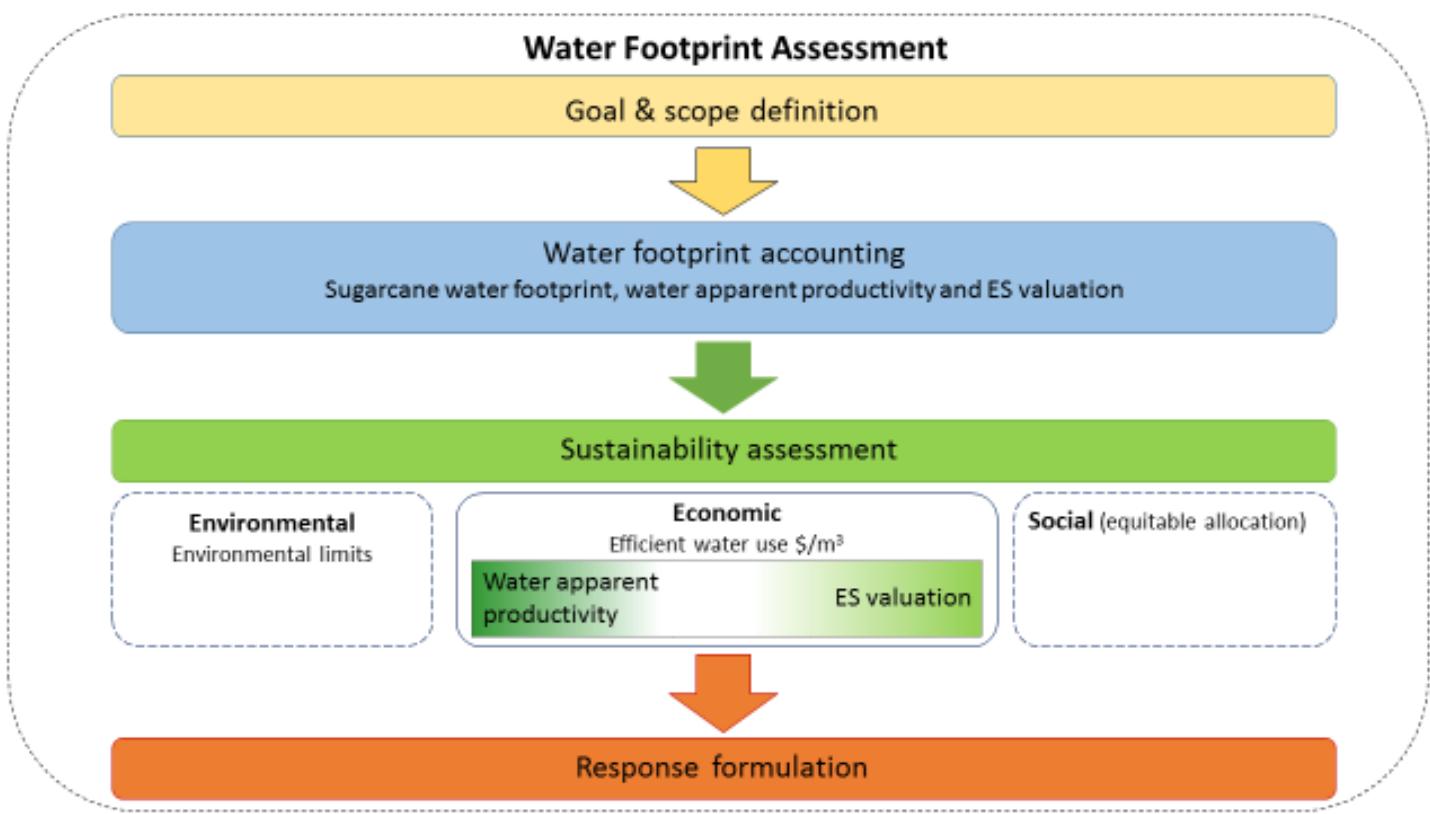

Figure 12.- Water Footprint Assessment framework and water apparent productivity and Ecosystem services valuation as part of the sustainability assessment phase

\subsubsection{Water Footprint accounting, water productivity and ES valuation}

Water footprint per unit of land use is calculated by estimating green (i.e. rainfall stored in the soil matrix) and blue (i.e. surface and groundwater) water consumption per unit of area of each land use $\left(\mathrm{m}^{3} \mathrm{ha}^{-1}\right)$. Yearly blue and green water consumption for crops were estimated according to Allen et al.(2006). Data to determine water consumption per crop were assembled from various sources. Planting datesdata were obtained from Embrapa (2014). Data on crop coefficient values $\left(K_{c}\right)$ were obtained from Allen $e t$ al., (2003). Climate data at municipal level were obtained from Rolim et al., (1998) and Sentelhas et al. (1999).

Sugarcane is partly irrigated, whereby fertigation is practiced. Fertigation was estimated based on the plant's $\mathrm{K}_{2} \mathrm{O}$ needs of $135 \mathrm{~kg} \mathrm{ha}^{-1}$ (Gaspar, 2012). The amount of vinasse required is applied in $20 \mathrm{~mm}$ increments per crop development stage. It was assumed that $33 \%$ of the cultivated area is fertigated with vinasse (Gaspar, 2012), according to the $\mathrm{K}$ fertilization needs of sugarcane. 
CHAPTER 5: ECONOMIC AND ECOSYSTEM SERVICES VALUATION OF LAND

AND WATER USE IN BRAZILIAN SUGARCANE UNDER EVOLVING

MANAGEMENT PRACTICES AND LAND USE CHANGEINCREASING

EFFICIENCY IN ETHANOL PRODUCTION: WATER FOOTPRINT AND

ECONOMIC PRODUCTIVITY OF SUGARCANE ETHANOL UNDER EIGHT

IRRIGATION LEVELS IN NORTH-EASTERN BRAZILTHE WATER FOOTPRINT

ASSESSMENT OF A PAIR OF JEANS: INFLUENCE OF AGRICULTURAL PRODUCTION IN CONSUMER PRODUCT'S SUSTAINABILITY

The method of Allen et al. (2006) is develop for crops, but is not applicable to estimate water consumption of eucalyptus, tropical areas or savannah-like cerrados. In the case of these land use categories, literature provides a varied range of water consumption relative to precipitation and reference evapotranspiration (ETo). In the case of pastures, there is high uncertainty in the estimation of the water consumption using values from Allen et al. (2006). For this reason, we used the semi-empirical approach proposed in Zhang et al. (2001) to estimate the water consumption of these land uses (EQ 1).

$$
E T_{i, m}=P_{m} \times\left(\frac{1+\omega_{i} \times \frac{E T_{o, m}}{P_{m}}}{\left(1+\omega_{i} \times \frac{E T_{o, m}}{P_{m}}\right)+\left(\frac{P_{m}}{E T_{o, m}}\right)}\right)
$$

Where $E T_{i, m}$ is the Evapotranspiration ( $\mathrm{mm}$. year ${ }^{-1}$ ) per land use $i$, municipality $m ; P_{m}$ is the annual precipitation ( $\mathrm{mm}_{\text {year }}{ }^{-1}$ ) per municipality $m, E T_{o, m}$ per land use $i$, municipality $m$ $\left(\mathrm{mm}\right.$. year $\left.{ }^{-1}\right)$ and $\omega_{i}$ is the water availability coefficient per land use $i$. The water availability coefficient in EQ 1 is a dimensionless factor describing the ability of each type of vegetation to use water available in the soil, dependent on soil properties and vegetation type.

The result of the evapotranspiration thus calculated is largely dependent on the selection of the water availability coefficient. This work has aimed to include a reflection of the high variability and uncertainty in the estimation of water consumption in these areas; pastures, eucalyptus plantations and natural areas by using a probabilistic approach for this coefficient that allows to build a continuous frequency distribution for ET. This approach allows us to define a range of results for each of the three land use categories.

The economic sustainability component of sugarcane is measured in relative terms, comparing sugarcane economic value of water to other land uses in the river basin. The economic value of water is reflected here by the water apparent productivity, estimated as the market price of production (US\$ $\mathrm{t}^{-1}$ ) divided by total green and blue water footprint per land use.

$$
W A P_{i, y, m}=\operatorname{Prod}_{i, y} \times P r_{i, y} / W F_{i, y, m} \quad[\text { EQ 2] }
$$


CHAPTER 5: ECONOMIC AND ECOSYSTEM SERVICES VALUATION OF LAND

AND WATER USE IN BRAZILIAN SUGARCANE UNDER EVOLVING

MANAGEMENT PRACTICES AND LAND USE CHANGEINCREASING EFFICIENCY IN ETHANOL PRODUCTION: WATER FOOTPRINT AND ECONOMIC PRODUCTIVITY OF SUGARCANE ETHANOL UNDER EIGHT IRRIGATION LEVELS IN NORTH-EASTERN BRAZILTHE WATER FOOTPRINT ASSESSMENT OF A PAIR OF JEANS: INFLUENCE OF AGRICULTURAL PRODUCTION IN CONSUMER PRODUCT'S SUSTAINABILITY

Where $W A P_{i, y, m}$ is the water apparent productivity $\left(\$ .\left(\$ \mathrm{~m}^{3}\right)\right.$ per land use i, municipality $\mathrm{m}$ and year y; $\operatorname{Prod}_{i, y}$ is the annual production $\left(\mathrm{t} \mathrm{ha}^{-1}\right)$ per land use $\mathrm{i}$, and year y; $\operatorname{Pr}_{i, y}$ is the price per product and $W F_{i, y, m}$ is the water consumption (either green or blue plus green) per land use i, municipality $\mathrm{m}\left(\mathrm{m}^{3} \cdot \mathrm{ha}^{-1} \cdot \mathrm{year}^{-1}\right)$ and year $\mathrm{y}$.

The economic value of the production with respect to the different land uses is calculated by multiplying the production per ha $\left(\mathrm{t} \mathrm{ha}^{-1}\right)$ with the market price of production $\left(\$ \mathrm{t}^{-1}\right)$. In the case of cropping areas, the product is the crop yield. In the case of eucalyptus, it refers to the production of cellulose and wood. For Eucalyptus wood productivity, the national average data (2008-2011) provided by the Brazilian Association of Forestry Sector Producers for eucalyptus plantations was used (BRACELPA, 2014). For the years 2000-2006 the average value of $46 \mathrm{~m}^{3} \mathrm{ha}^{-1}$ year ${ }^{-1}$ was reported by the Brazilian Association of Forestry Sector Producers for São Paulo state (BRACELPA, 2014). A wood density value of 0.479 grcc $^{-1}$ for E. Globulus in Mogí-Guaçu, as estimated by Ribeiro (1993), is used here.

In the case of pasture lands productivity is estimated based on municipal meat and milk production. Pasture areas were valued by dividing the value of animal products per municipality, that is, bovine meat and milk, among the pasture and fodder crop areas. Eucalyptus was valued based on prices given by the National Statistics Institute (IBGE, 2016) on wood products, taking the prices for wood, and wood for cellulose production. No economic value was associated with natural areas.

We used market prices in Real (Brazilian currency) terms using the values provided by the IEA (2014). Data on prices for animal and crop products were obtained from the IEA price database (IEA, 2014b). Time series for conversion from current to constant prices were obtained from IEA (IEA, 2014b) and transformed from Brazilian Real to US Dollars at a constant rate of $2.22 \mathrm{R} \$ \mathrm{US}^{-1}$, the average exchange rate in the time period under consideration using annual exchange rates from the same database.

We focus the analysis on a selection of land and water ES directly related to the hydrological cycle, water provisioning and erosion. Water provisioning is estimated as a measure of the potential for runoff generation. Erosion potential is associated to the 
CHAPTER 5: ECONOMIC AND ECOSYSTEM SERVICES VALUATION OF LAND

AND WATER USE IN BRAZILIAN SUGARCANE UNDER EVOLVING

MANAGEMENT PRACTICES AND LAND USE CHANGEINCREASING

EFFICIENCY IN ETHANOL PRODUCTION: WATER FOOTPRINT AND

ECONOMIC PRODUCTIVITY OF SUGARCANE ETHANOL UNDER EIGHT

IRRIGATION LEVELS IN NORTH-EASTERN BRAZILTHE WATER FOOTPRINT

ASSESSMENT OF A PAIR OF JEANS: INFLUENCE OF AGRICULTURAL PRODUCTION IN CONSUMER PRODUCT'S SUSTAINABILITY

economic costs of removal of sediments silting up in reservoirs downstream and the treatment costs of increased turbidity in rivers. Both ES are calculated as a function of vegetation ET and its water footprint.

Ecosystem services valuation is a two-step procedure: estimation of the biophysical dimension (the amount of service provided) and a valuation thereof. In the present study we quantified, in biophysical and economic terms, the capacity of the different land uses of the MGP to supply two key water-related services: water provisioning, i.e. the potential of a specific land use for generating runoff and soil erosion.

Water provisioning by land use has been estimated following the InVEST methodology (Tallis et al., 2013), as:

$$
W P S_{i, m, y}=\left(1-\frac{W F_{i, m, y}}{P_{m, y}}\right) \times P_{m, y} \times A_{i, m, y} \times P w \quad[\mathrm{EQ} 3]
$$

Where $W P S_{i, m, y}$ is the economic value of water provisioning per land use $\mathrm{i}$, year $\mathrm{y}$ and municipality $\mathrm{m}\left(\mathrm{R} \$\right.$ year $\left.^{-1}\right), W F_{i, m, y}$ is the WF (either green or blue plus green) ( $\mathrm{m}^{3} \mathrm{ha}^{-1}$ year $\left.{ }^{1}\right)$ and $P_{m}$ is the annual precipitation $\left(\mathrm{m}^{3} \mathrm{ha}^{-1}\right.$ year $\left.^{-1}\right), A_{i, m, y} A_{i, m, y}$ is the area per land use, municipality and year (ha) and $P w$ is the value of water

$P w$ is and $P w$ is the value of water, giving a probabilistic nature in order to cover the full range of water price as provided by the São Paulo state, an average of $0.01-0.033 \mathrm{R} \$ \mathrm{~m}^{-3}$, the water prices range indicated in the legislation for water abstraction and consumption. (SP, 2005).

The effect of erosion is analysed both in terms of the economic cost treatment of suspended solids in water supply plants and of sediment dredging to prevent reservoir silting up downstream, following de Sousa Jr. (2010):

$$
E C_{i, m, y}=\left(\text { Cturb }_{i, m, y}+\text { Cdred }_{i, m, y}\right) \times A_{i, m, y} \quad[\mathrm{EQ} 4]
$$

Where $E C_{i, m, y}$ are the erosion costs per land use i, year y and municipality $\mathrm{m}\left(\mathrm{R} \$\right.$ year $\left.^{-1}\right)$, the economic losses for the producer associated to erosion $C \operatorname{Ctur} b_{i, m, y}$ the costs of the 
CHAPTER 5: ECONOMIC AND ECOSYSTEM SERVICES VALUATION OF LAND

AND WATER USE IN BRAZILIAN SUGARCANE UNDER EVOLVING

MANAGEMENT PRACTICES AND LAND USE CHANGEINCREASING EFFICIENCY IN ETHANOL PRODUCTION: WATER FOOTPRINT AND ECONOMIC PRODUCTIVITY OF SUGARCANE ETHANOL UNDER EIGHT IRRIGATION LEVELS IN NORTH-EASTERN BRAZILTHE WATER FOOTPRINT ASSESSMENT OF A PAIR OF JEANS: INFLUENCE OF AGRICULTURAL PRODUCTION IN CONSUMER PRODUCT'S SUSTAINABILITY

treatment of water turbidity associated to erosion and $C d r e d_{i, m, y}$ the costs of sediment removal per land use i, year y and municipality $\mathrm{m}\left(\mathrm{R} \$\right.$ year $\left.^{-1}\right)$.

For the valuation of erosion costs, erosion rates per land use $\left(\mathrm{t} \mathrm{ha}^{-1}\right)$ are the underlying variable that determines both the costs of treatment of water turbidity and of sediment dredging downstream. Here, we used again a probabilistic approach in which we defined a continuous frequency distribution by fitting literature values per land use and then modelled the results in a Monte Carlo analysis. Erosion rates per land use were obtained from the literature review performed by Anache et al. (2017) for all the land uses except for sugarcane. Erosion rates in sugarcane reported in the literature vary considerably depending on the harvesting technique used, whether it is manually or mechanically harvested sugarcane. For this reason a literature review of potential erosion rates in sugarcane was performed. Data on the percentage of sugarcane harvested mechanically per municipality was obtained from Aguiar et al. (2011).

The costs associated with generation of turbidity are estimated according to de Sousa Jr. (2010) and based on the calculation of the fraction of eroded material that is carried by surface waters as suspended solids, its relation to turbidity in rivers and the costs of treating turbidity to reach drinking water standards, using a series of empirical models from Teixeira e Senhorelo (2000). Potential suspended solid generation is defined as a function of soil loss, sediment generation fraction and potential runoff. Potential runoff per land use and municipality was estimated with Eq. 3. Soil loss was estimated as the erosion rates. Sediment generation rate is a parameter reflecting the amount of sediments in water flows generated from soil erosion in a river basin. A range of values from 0.12 to 0.75 with an average of 0.13 as reported by Chaves (2010) in de Sousa Jr. (2010) is used in the present study.

In a similar way, the costs of sediment dredging in downstream reservoirs are a function of soil loss, sediment generation fraction and unit costs of sediment removal. Both soil loss and sediment generation fraction are estimated as indicated above. Costs of sediment dredging used follow the indication of de Sousa Jr. (2010) of a range from 6.7 to $20 \mathrm{R} \$ \mathrm{t}^{-1}$ of sediment with an average of $16.7 \mathrm{R} \$ \mathrm{t}^{-1}$. 
CHAPTER 5: ECONOMIC AND ECOSYSTEM SERVICES VALUATION OF LAND

AND WATER USE IN BRAZILIAN SUGARCANE UNDER EVOLVING MANAGEMENT PRACTICES AND LAND USE CHANGEINCREASING EFFICIENCY IN ETHANOL PRODUCTION: WATER FOOTPRINT AND ECONOMIC PRODUCTIVITY OF SUGARCANE ETHANOL UNDER EIGHT IRRIGATION LEVELS IN NORTH-EASTERN BRAZILTHE WATER FOOTPRINT ASSESSMENT OF A PAIR OF JEANS: INFLUENCE OF AGRICULTURAL PRODUCTION IN CONSUMER PRODUCT'S SUSTAINABILITY

To show the results of the ES value generated in terms of water use we employ the concept of ES value per unit of water, as the relation between ES value generated to the water footprint, which can be calculated as:

$$
E S W P_{i, m, y, c}=\left(W P S_{i, m, y}-E C_{i, m, y, c}\right) /_{W F_{i, y, m}} \quad[\mathrm{EQ} 5]
$$

Where $E S W P_{i, m, y}$ is the ES value per unit of water, per land use i, year y and municipality $\mathrm{m}$ and erosion rate level in the case of sugarcane $\left(\mathrm{R} \$ \mathrm{~m}^{-3}\right)$. Since erosion effects are considered a cost instead of a benefit, their valuation is negative.

A summary of the probabilistic variables used is show in Table 8 . Water availability factor ( $\omega$ ) distributions were considered normal and parametrized so that the resulting ET values fit literature values. In the case of pasture areas, we distinguished between managed and natural pastures and adjusted $\omega$ so that it would fit the ET as modelled following Allen et al. (2006) and using the Kc values from the same publication. In the case of Eucalyptus plantations and tropical rainforest the resulting ET followed the values reported in Salemi et al. (2013), and Almeida and Soares, (2003), 52\% to $96 \%$ of precipitation. For savannah like areas, (Cerrado and Cerradao; open and closed savannah) resulting ET in $\mathrm{mm} \mathrm{day}^{-1}$, followed the results from Giambelluca et al., (2009) and Olivera et al., (2005). Best fit for erosion rates reported in Anache et al. (2017) was found to be the exponential distribution. 
CHAPTER 5: ECONOMIC AND ECOSYSTEM SERVICES VALUATION OF LAND AND WATER USE IN BRAZILIAN SUGARCANE UNDER EVOLVING MANAGEMENT PRACTICES AND LAND USE CHANGEINCREASING EFFICIENCY IN ETHANOL PRODUCTION: WATER FOOTPRINT AND ECONOMIC PRODUCTIVITY OF SUGARCANE ETHANOL UNDER EIGHT IRRIGATION LEVELS IN NORTH-EASTERN BRAZILTHE WATER FOOTPRINT ASSESSMENT OF A PAIR OF JEANS: INFLUENCE OF AGRICULTURAL PRODUCTION IN CONSUMER PRODUCT'S SUSTAINABILITY

Table 8 - Parameters used the estimation of water consumption per land use

\begin{tabular}{|c|c|c|c|}
\hline Variable & $\begin{array}{l}\text { Land } \\
\text { type }\end{array}$ & Land use & Probabilistic variable \\
\hline \multirow{6}{*}{$\begin{array}{l}\text { Water } \\
\text { availabilty } \\
\text { factor } \omega\end{array}$} & \multirow{2}{*}{ Pasture } & Natural pastures & Crop $\omega \sim \mathrm{N}(1,0,55)$ \\
\hline & & Managed pastures & $\omega \sim \mathrm{N}(1.9,0,5)$ \\
\hline & Eucalyptus & Eucalyptus & $\omega \sim \mathrm{N}(1.9,1,75)$ \\
\hline & \multirow{3}{*}{$\begin{array}{l}\text { Natural } \\
\text { vegetation }\end{array}$} & $\begin{array}{l}\text { Tropical humid forest } \\
\text { (Mata) }\end{array}$ & $\omega \sim \mathrm{N}(2,2)$ \\
\hline & & Open savannah (Cerrado) & $\omega \sim \mathrm{N}(0.9,1.3)$ \\
\hline & & $\begin{array}{l}\text { Wooded savannah } \\
\text { (Cerradao) }\end{array}$ & $\omega \sim \mathrm{N}(1.5,1,65)$ \\
\hline \multirow{13}{*}{$\begin{array}{l}\text { Erosion rates }(\mathrm{t} \\
\left.\mathrm{ha}^{-1}\right)\end{array}$} & \multirow{5}{*}{ Annual crops } & $\begin{array}{l}\text { Maize, main harvest, second } \\
\text { harvest }\end{array}$ & $\begin{array}{l}\text { Erosion rate } \sim \\
\text { Exponential }(6.2)\end{array}$ \\
\hline & & $\begin{array}{l}\text { Beans, main harvest, second } \\
\text { harvest }\end{array}$ & $\begin{array}{l}\text { Erosion rate } \sim \\
\text { Exponential }(13.3)\end{array}$ \\
\hline & & Soybeans, second harvest & $\begin{array}{l}\text { Erosion rate } \sim \\
\text { Exponential }(26.7)\end{array}$ \\
\hline & & $\begin{array}{l}\text { Peanuts, main harvest, } \\
\text { second harvest }\end{array}$ & $\begin{array}{l}\text { Erosion rate } \sim \\
\text { Exponential }(8.2)\end{array}$ \\
\hline & & $\begin{array}{l}\text { Shorgum, main harvest, } \\
\text { second harvest }\end{array}$ & $\begin{array}{l}\text { Erosion rate } \sim \\
\text { Exponential(10.21) }\end{array}$ \\
\hline & \begin{tabular}{|l} 
Coffee \\
plantations
\end{tabular} & Coffee plantations & \begin{tabular}{|l|} 
Erosion rate $\sim$ \\
Exponential $(2.8)$ \\
\end{tabular} \\
\hline & $\begin{array}{l}\text { Orange } \\
\text { orchards }\end{array}$ & $\begin{array}{l}\text { Orange orchards, irrigated } \\
\text { orange orchards }\end{array}$ & $\begin{array}{l}\text { Erosion rate } \sim \\
\text { Exponential }(2.94)\end{array}$ \\
\hline & \multirow{2}{*}{ Sugarcane } & Manual harvesting & $\begin{array}{l}\text { Erosion rate } \sim \\
\text { Exponential }(11.901)\end{array}$ \\
\hline & & Mechanical harvesting & $\begin{array}{l}\text { Erosion rate } \sim \\
\text { Exponential }(5.332)\end{array}$ \\
\hline & Pasture & $\begin{array}{l}\text { Natural pastures, managed } \\
\text { pastures }\end{array}$ & \begin{tabular}{|l|} 
Erosion rate $\sim$ \\
Exponential $(1.181)$ \\
\end{tabular} \\
\hline & Eucalyptus & Eucalyptus & $\begin{array}{l}\text { Erosion rate } \sim \\
\text { Exponential }(0.0903)\end{array}$ \\
\hline & \begin{tabular}{|l|} 
Natural \\
vegetation \\
\end{tabular} & $\begin{array}{l}\text { Tropical humid forest } \\
\text { (Mata) }\end{array}$ & $\begin{array}{l}\text { Erosion rate } \sim \\
\text { Exponential }(0.096)\end{array}$ \\
\hline & $\begin{array}{l}\text { Natural } \\
\text { vegetation }\end{array}$ & $\begin{array}{l}\text { Open savannah (Cerrado), } \\
\text { Wooded savannah } \\
(\text { Cerradao })\end{array}$ & $\begin{array}{l}\text { Erosion rate } \sim \\
\text { Exponential }(0.038)\end{array}$ \\
\hline $\begin{array}{l}\text { Sediment } \\
\text { generation rate }\end{array}$ & / & / & $\begin{array}{l}\text { Sediment generation rate } ~ \\
\mathrm{~N}(0.13,0.013)\end{array}$ \\
\hline
\end{tabular}


CHAPTER 5: ECONOMIC AND ECOSYSTEM SERVICES VALUATION OF LAND AND WATER USE IN BRAZILIAN SUGARCANE UNDER EVOLVING MANAGEMENT PRACTICES AND LAND USE CHANGEINCREASING EFFICIENCY IN ETHANOL PRODUCTION: WATER FOOTPRINT AND ECONOMIC PRODUCTIVITY OF SUGARCANE ETHANOL UNDER EIGHT IRRIGATION LEVELS IN NORTH-EASTERN BRAZILTHE WATER FOOTPRINT ASSESSMENT OF A PAIR OF JEANS: INFLUENCE OF AGRICULTURAL PRODUCTION IN CONSUMER PRODUCT'S SUSTAINABILITY

\begin{tabular}{l|l|l|l}
\hline $\begin{array}{l}\text { Water cost }(\mathrm{R} \$ \\
\left.\mathrm{m}^{-3}\right)\end{array}$ & $/$ & $/$ & $\begin{array}{l}\text { Water cost } \sim \\
\text { Uniform }(0.01-0.013)\end{array}$ \\
\hline $\begin{array}{l}\text { Unit Cost of } \\
\text { sediment } \\
\text { dredging }\left(\mathrm{R} \$ \mathrm{t}^{-1}\right)\end{array}$ & $/$ & $/$ & $\begin{array}{l}\text { Unit cost sediment dredging } \\
\sim \mathrm{N}(16.7-1.67)\end{array}$ \\
\hline
\end{tabular}


CHAPTER 5: ECONOMIC AND ECOSYSTEM SERVICES VALUATION OF LAND

AND WATER USE IN BRAZILIAN SUGARCANE UNDER EVOLVING MANAGEMENT PRACTICES AND LAND USE CHANGEINCREASING EFFICIENCY IN ETHANOL PRODUCTION: WATER FOOTPRINT AND ECONOMIC PRODUCTIVITY OF SUGARCANE ETHANOL UNDER EIGHT IRRIGATION LEVELS IN NORTH-EASTERN BRAZILTHE WATER FOOTPRINT ASSESSMENT OF A PAIR OF JEANS: INFLUENCE OF AGRICULTURAL PRODUCTION IN CONSUMER PRODUCT'S SUSTAINABILITY

\subsection{Results}

\subsubsection{Sugarcane WF accounting}

Between 2000 and 2012 the total economic value generated by sugarcane production increased by $410 \%$, from 864 million US\$ to 4,412 million US\$ (Table 9). This is related to both the increase in production and the increase in price, whereby the price has increased

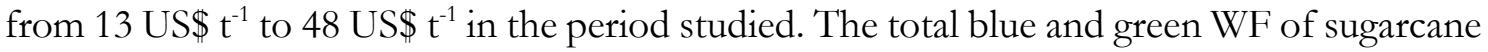
also increased in parallel to the increase in cultivated area. As a result, water apparent productivity has increased from $0.09 \mathrm{US} \$ \mathrm{~m}^{-3}$ to $0.33 \mathrm{US} \$ \mathrm{~m}^{-3}$. Yield is another factor that can condition the WF results and so the WAP of crops. However, in this case sugarcane yields in the basin, on average $72.03 \mathrm{t} \mathrm{ha}^{-1}$, have shown little growth, with an average annual increase of $0.5 \%$ throughout the period assessed. The economic value of sugarcane production is still two orders of magnitude higher than the value of ES taken into account.

Table 9.- Sugarcane area cultivated (ha), economic value generated $\left(1,000 \$\right.$ year $\left.^{-1}\right)$, green and blue water footprint $\left(\mathrm{Mm}^{3}\right.$ year $\left.{ }^{-1}\right)$, water apparent productivity $\left(\$ \mathrm{~m}^{-3}\right)$ and total Ecosystem services value $\left(1,000 \$\right.$ year $\left.{ }^{-1}\right)$

\begin{tabular}{|c|c|c|c|c|c|c|c|c|}
\hline \multirow{2}{*}{ Year } & \multirow{2}{*}{$\begin{array}{l}\text { Total area } \\
\left(\text { ha year }^{-1}\right)\end{array}$} & \multirow{2}{*}{$\begin{array}{c}\text { Total } \\
\text { Economic } \\
\text { Value } \\
(\$ 1,000 \\
\left.\text { year }^{-1}\right)\end{array}$} & \multirow{2}{*}{$\begin{array}{l}\text { Green } \\
\text { WF } \\
\left(\mathrm{Mm}^{3}\right. \\
\left.\text { year }^{-1}\right)\end{array}$} & \multirow{2}{*}{$\begin{array}{l}\text { Blue } \\
\text { WF } \\
\left(\mathrm{Mm}^{3}\right. \\
\left.\text { year }^{-1}\right)\end{array}$} & \multirow{2}{*}{$\begin{array}{c}\text { Water } \\
\text { apparent } \\
\text { producti- } \\
\text { vity } \\
\left(\$ \mathrm{~m}^{-3}\right)\end{array}$} & \multicolumn{3}{|c|}{$\begin{array}{l}\text { Total ES value } \\
\left(\$ 1,000 \text { year }^{-1}\right)\end{array}$} \\
\hline & & & & & & $5^{\text {th }} \mathrm{pc}$ & Average & $95^{\text {th }} \mathrm{pc}$ \\
\hline 2000 & 950,313 & 864,850 & 9,092 & 621 & 0.089 & 7,638 & $33,711.5$ & 46,620 \\
\hline 2001 & 991,387 & 919,334 & 9,484 & 648 & 0.091 & 8,010 & $35,066.1$ & 48,455 \\
\hline 2002 & $1,008,264$ & $1,038,858$ & 9,644 & 658 & 0.101 & 8,415 & $35,773.0$ & 49,377 \\
\hline 2003 & $1,050,874$ & $1,053,083$ & 10,039 & 687 & 0.098 & 8,985 & $37,020.4$ & 51,030 \\
\hline 2004 & $1,011,409$ & $1,094,856$ & 9,669 & 661 & 0.106 & 9,891 & $35,992.0$ & 49,346 \\
\hline 2005 & $1,062,130$ & $1,467,405$ & 10,147 & 694 & 0.135 & 11,976 & $37,876.7$ & 51,587 \\
\hline 2006 & $1,108,178$ & $2,016,248$ & 10,585 & 724 & 0.178 & 14,831 & $39,950.0$ & 53,817 \\
\hline 2007 & $1,144,846$ & $2,525,439$ & 10,936 & 747 & 0.216 & 18,207 & $41,759.6$ & 55,600 \\
\hline 2008 & $1,239,348$ & $2,960,564$ & 11,834 & 810 & 0.234 & 19,303 & $44,611.6$ & 59,346 \\
\hline 2009 & $1,230,703$ & $3,045,238$ & 11,750 & 804 & 0.243 & 21,433 & $45,085.1$ & 59,780 \\
\hline 2010 & $1,258,442$ & $4,087,558$ & 12,012 & 823 & 0.318 & 22,165 & $46,010.4$ & 60,931 \\
\hline 2011 & $1,270,868$ & $4,438,374$ & 12,134 & 831 & 0.342 & 23,297 & $46,582.2$ & 61,541 \\
\hline 2012 & $1,295,173$ & $4,412,236$ & 12,367 & 846 & 0.334 & 24,878 & $47,882.5$ & 63,163 \\
\hline
\end{tabular}


CHAPTER 5: ECONOMIC AND ECOSYSTEM SERVICES VALUATION OF LAND

AND WATER USE IN BRAZILIAN SUGARCANE UNDER EVOLVING MANAGEMENT PRACTICES AND LAND USE CHANGEINCREASING EFFICIENCY IN ETHANOL PRODUCTION: WATER FOOTPRINT AND ECONOMIC PRODUCTIVITY OF SUGARCANE ETHANOL UNDER EIGHT IRRIGATION LEVELS IN NORTH-EASTERN BRAZILTHE WATER FOOTPRINT ASSESSMENT OF A PAIR OF JEANS: INFLUENCE OF AGRICULTURAL PRODUCTION IN CONSUMER PRODUCT'S SUSTAINABILITY

The total ES value generated is the sum of the value of water provisioning service and erosion costs. The average value of water provisioning increased by $35 \%$, also linked to the increase in cultivated area, from an average of 39,021 to $52,52710^{3} \$ \mathrm{y}^{-1}$. The average of erosion costs, however has decreased by $13 \%$, from 5,309 to $4,64410^{3} \$ \mathrm{y}^{-1}$. The uncertainty of the estimation of erosion costs, understood as the difference between the $5^{\text {th }}$ and $95^{\text {th }}$ percentiles, has decreased throughout the period, as highest and lowest value of the estimation have approached (13). Average erosion rates in manual harvesting are higher than average erosion rates in mechanically -harvested sugarcane. Moreover, the variability of the estimation of erosion costs in manual harvesting is higher than in mechanical harvesting, so, as more area shifts from manual to mechanical harvesting, average erosion costs diminish and the estimation shows less variability.

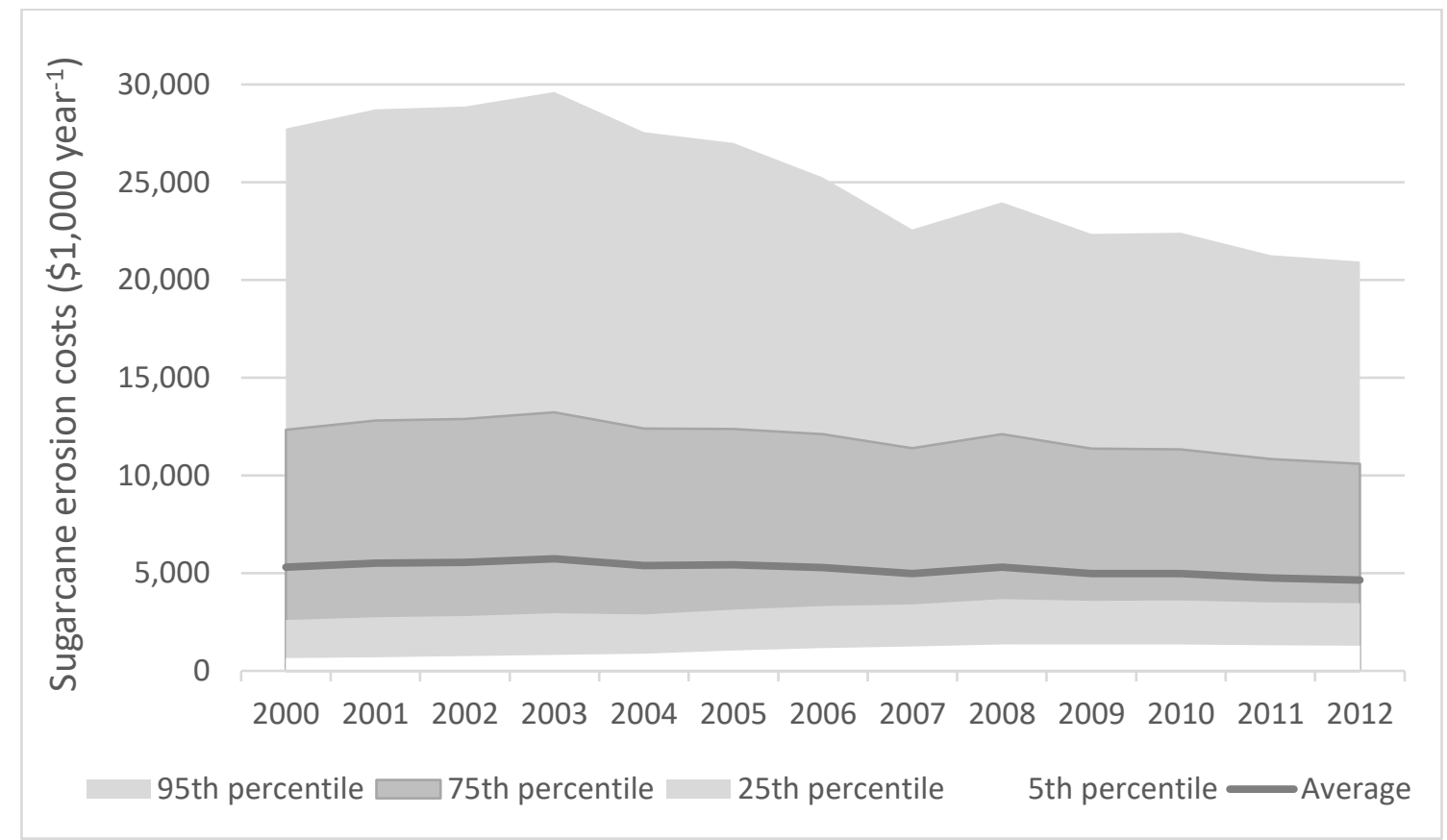

Figure 13.- Average and $5^{\text {th }}, 25^{\text {th }}, 75^{\text {th }}$ and $95^{\text {th }}$ percentiles of erosion costs in sugarcane $\left(1,000 \$ \mathrm{y}^{-1}\right)$

As a result of the increase in water provisioning service and the decrease in erosion costs, the value of ES generated per unit of water has increased throughout the period under consideration. Erosion costs are in all cases smaller than the value of water provisioning. 
CHAPTER 5: ECONOMIC AND ECOSYSTEM SERVICES VALUATION OF LAND

AND WATER USE IN BRAZILIAN SUGARCANE UNDER EVOLVING MANAGEMENT PRACTICES AND LAND USE CHANGEINCREASING EFFICIENCY IN ETHANOL PRODUCTION: WATER FOOTPRINT AND ECONOMIC PRODUCTIVITY OF SUGARCANE ETHANOL UNDER EIGHT IRRIGATION LEVELS IN NORTH-EASTERN BRAZILTHE WATER FOOTPRINT ASSESSMENT OF A PAIR OF JEANS: INFLUENCE OF AGRICULTURAL PRODUCTION IN CONSUMER PRODUCT'S SUSTAINABILITY

This means that ES value per unit of water will always be positive. Therefore, both the sugarcane water apparent productivity and the ES generated per unit of water have increased in the period, the first one linked to increase in sugarcane prices and the latter to the change in management practices. The change of manual harvesting to mechanical harvesting has brought benefits in this regard, lowering the total erosion and its associated costs. In spite of this, what we see is how the erosion rates in mechanical harvesting determine the net effect of sugarcane in terms of ES.

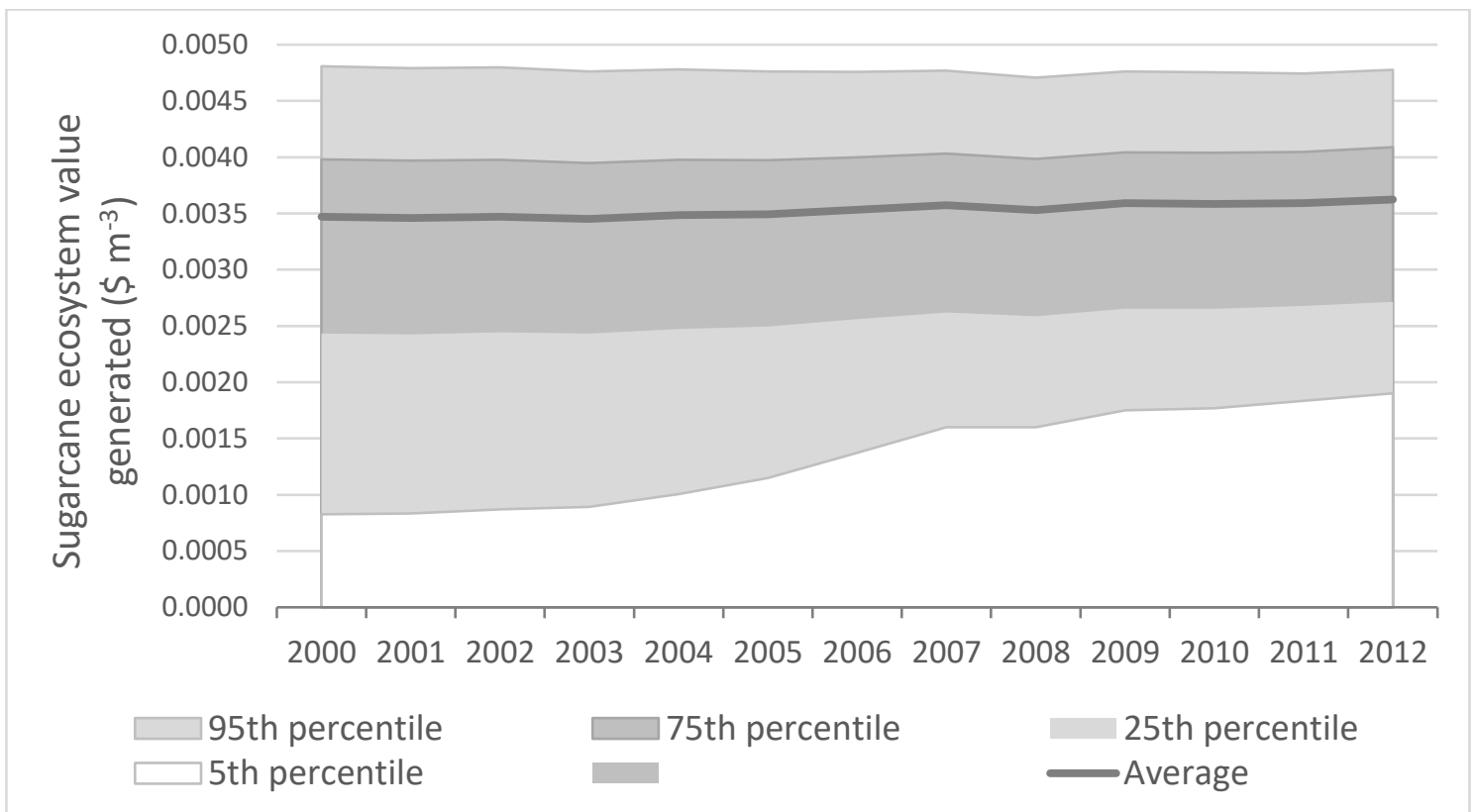

Figure $14-$ Average and $5^{\text {th }}, 25^{\text {th }}, 75^{\text {th }}$ and $95^{\text {th }}$ percentiles of sugarcane ES value per unit of water $\left(\$ \mathrm{~m}^{-3}\right)$

The changes in sugarcane harvesting have led to overall higher ES value per unit of water consumed (Figure 14). The graph shows the probabilistic result considering the distribution of erosion rates. The greatest improvement occurs in lower end of the range. As the results from Figure 13 indicate it is the improvement in the municipalities where the ES value per unit of water was lower, which resulted in an overall improvement. 
CHAPTER 5: ECONOMIC AND ECOSYSTEM SERVICES VALUATION OF LAND

AND WATER USE IN BRAZILIAN SUGARCANE UNDER EVOLVING

MANAGEMENT PRACTICES AND LAND USE CHANGEINCREASING EFFICIENCY IN ETHANOL PRODUCTION: WATER FOOTPRINT AND ECONOMIC PRODUCTIVITY OF SUGARCANE ETHANOL UNDER EIGHT IRRIGATION LEVELS IN NORTH-EASTERN BRAZILTHE WATER FOOTPRINT ASSESSMENT OF A PAIR OF JEANS: INFLUENCE OF AGRICULTURAL PRODUCTION IN CONSUMER PRODUCT'S SUSTAINABILITY

\subsubsection{Water productivity in the MGP river basin}

To put these results into context and to better understand the efficiency of water use associated with sugarcane in the MGP river basin all remaining land uses in the basin have also been evaluated. Looking to the market value generated, coffee plantations and sugarcane fields generate the highest economic value per ha (Table 10), in contrast to eucalyptus plantations and pasture areas, which provide lower revenues. If we focus on ES valuation, pastures provide the highest value of ES, between 7.5 and $44.3 \$ \mathrm{ha}^{-1}$, followed by natural areas. In the case of natural areas, the values obtained range between Eucalyptus plantations, orange orchards and coffee plantations would be other land uses that generate high ES value. In the case of eucalyptus plantations, however, despite the range of results these areas could be considered as an intermediate case between pasture areas, orange orchards and coffee plantations on the one side and sugarcane and annual crops on the other side. Sugarcane and annual crops result in the lowest ES values, having on average negative productivity, as erosion costs outweigh the value of water generated.

Comparing among land uses points to stress the trade-offs, since the economic and environmental performance of the land use classes stand against each other. As a result, sugarcane, by far the most extended land use type in the basin, provides the second highest economic value, second high water consumption and lower ES than other land uses. Annual crops show the lowest water consumption, provide an intermediate economic value per ha and lowest value linked to ES if we compare it to other land uses. Eucalyptus plantations, pasture and natural areas provide, in average, low economic value per land area, have high water consumption and provide higher value linked to the ES compared to the other uses. Orange orchards have a better economic performance and worse ratings in terms of ES at the expense of high water consumption. Orange orchards would represent a balanced choice, when compared to the other uses. Coffee plantations provide good economic value (but also have high water consumption), showing high economic efficiency of water use. Nevertheless, they rank 5th among the studied land uses in terms of ES. 
CHAPTER 5: ECONOMIC AND ECOSYSTEM SERVICES VALUATION OF LAND AND WATER USE IN BRAZILIAN SUGARCANE UNDER EVOLVING MANAGEMENT PRACTICES AND LAND USE CHANGEINCREASING EFFICIENCY IN ETHANOL PRODUCTION: WATER FOOTPRINT AND ECONOMIC PRODUCTIVITY OF SUGARCANE ETHANOL UNDER EIGHT IRRIGATION LEVELS IN NORTH-EASTERN BRAZILTHE WATER FOOTPRINT ASSESSMENT OF A PAIR OF JEANS: INFLUENCE OF AGRICULTURAL PRODUCTION IN CONSUMER PRODUCT'S SUSTAINABILITY

Table 10.- Economic value $\left(\$ h^{-1}\right)$, water consumption $\left(\mathrm{m}^{3}\right.$ ha-1) value of water provisioning $\left(\$ \mathrm{ha}^{-1}\right)$, erosion costs $(\$$ ha-1) and value of ES $(\$$ ha-1) per land use. Averages per municipality and year, $5^{\text {th }}$ and $95^{\text {th }}$ percentiles

\begin{tabular}{|c|c|c|c|c|c|c|c|c|c|c|c|c|c|c|c|c|}
\hline \multirow[t]{2}{*}{ Land use class } & \multirow{2}{*}{$\begin{array}{c}\text { Total } \\
\text { Economic } \\
\text { Value }(\$ \\
\left.\mathrm{ha}^{-1}\right)\end{array}$} & \multicolumn{3}{|c|}{$\begin{array}{l}\text { Water consumption } \\
\qquad\left(\mathrm{m}^{3} \mathrm{ha}^{-1}\right)\end{array}$} & \multicolumn{3}{|c|}{$\begin{array}{l}\text { Water apparent } \\
\text { productivity }\left(\$ \mathrm{~m}^{-3}\right)\end{array}$} & \multicolumn{3}{|c|}{$\begin{array}{c}\text { Total Value of } \\
\text { Water Provisioning } \\
\left(\$ \mathrm{ha}^{-1}\right)\end{array}$} & \multicolumn{3}{|c|}{$\begin{array}{l}\text { Total Erosion Costs } \\
\qquad\left(\$ \mathrm{ha}^{-1}\right)\end{array}$} & \multicolumn{3}{|c|}{$\begin{array}{l}\text { Total ES value } \\
\qquad\left(\$ \mathrm{ha}^{-1}\right)\end{array}$} \\
\hline & & $5^{\text {th }} \mathrm{pc}$ & Av & $95^{\text {th }} \mathrm{pc}$ & $5^{\text {th }} \mathrm{pc}$ & Av & $95^{\text {th }} \mathrm{pc}$ & $5^{\text {th }} \mathrm{pc}$ & $\mathrm{Av}$ & $\begin{array}{l}95^{\text {th }} \\
\mathrm{pc}\end{array}$ & $5^{\text {th }} \mathrm{pc}$ & $A v$ & $95^{\text {th }} \mathrm{pc}$ & $5^{\text {th }} \mathrm{pc}$ & $A v$ & $95^{\text {th }} \mathrm{pc}$ \\
\hline Annual crops & 1,060 & & 4,176 & & & 0.254 & & & 36.2 & & 2.5 & 4.98 & 19.8 & 12.1 & 31.2 & 41.3 \\
\hline Sugarcane & 2,047 & & 10,207 & & & 0.201 & & & 40.7 & & 1.4 & 4.93 & 23.5 & 13.4 & 35.8 & 48.1 \\
\hline Coffee & 3,326 & & 10,389 & & & 0.320 & & & 48.9 & & 0.2 & 1.37 & 7.1 & 31.6 & 47.5 & 61.7 \\
\hline Orange Orchards & 1,403 & & 8,468 & & & 0.166 & & & 58.6 & & 0.5 & 1.92 & 9.1 & 37.5 & 56.7 & 73.6 \\
\hline $\begin{array}{l}\text { Eucalyptus } \\
\text { plantations }\end{array}$ & 452 & 6,745 & 8,864 & 10,811 & 0.042 & 0.051 & 0.067 & 34.1 & 61.1 & 100.1 & 0.1 & 0.44 & 2.3 & 33.2 & 60.7 & 99.4 \\
\hline Pastures & 506 & 7,816 & 8,395 & 8,943 & 0.057 & 0.060 & 0.065 & 46.9 & 67.5 & 90.2 & 0.3 & 0.96 & 4.3 & 45.2 & 66.6 & 88.5 \\
\hline $\begin{array}{l}\text { Natural } \\
\text { Vegetation }\end{array}$ & 0 & 7,136 & 8,697 & 9,752 & 0.000 & 0.000 & 0.000 & 41.7 & 61.5 & 94.2 & 0.0 & 0.0 & 160.2 & -102.4 & 61.4 & 93.1 \\
\hline TOTAL & 1,256 & 8,594 & 8,839 & 8,983 & 0.140 & 0.142 & 0.146 & 35.6 & 50.3 & 66.5 & 1.8 & 3.1 & 24.7 & 20.1 & 47.1 & 62.0 \\
\hline
\end{tabular}


CHAPTER 5: ECONOMIC AND ECOSYSTEM SERVICES VALUATION OF LAND

AND WATER USE IN BRAZILIAN SUGARCANE UNDER EVOLVING

MANAGEMENT PRACTICES AND LAND USE CHANGEINCREASING

EFFICIENCY IN ETHANOL PRODUCTION: WATER FOOTPRINT AND

ECONOMIC PRODUCTIVITY OF SUGARCANE ETHANOL UNDER EIGHT

IRRIGATION LEVELS IN NORTH-EASTERN BRAZILTHE WATER FOOTPRINT

ASSESSMENT OF A PAIR OF JEANS: INFLUENCE OF AGRICULTURAL PRODUCTION IN CONSUMER PRODUCT'S SUSTAINABILITY

The result of the evapotranspiration in pastures, eucalyptus plantations and natural areas calculated through EQ 1 is largely dependent on the selection of the water availability coefficient. Literature describes ample variability in the estimation of water consumption, pastures, eucalyptus plantations and natural areas, both for tropical rainforest and savannahlike areas that was used to adjust the results of this work. Salemi et al. (2013), and Almeida and Soares, 2003) report values ranging from 52 to $98 \%$ of the precipitation for tropical rainforest and eucalyptus plantations. Giambelluca et al., (2009) and Olivera et al. (2005) report for savannah like areas, Cerrado and Cerradao daily ET of 1.1-2.5 $\mathrm{mm}^{-1} \mathrm{y}^{-1}$ for dry season and 1.5-3.2 mm day ${ }^{-1}$ in the wet season, which corresponds in this area to $783 \mathrm{~m}^{3} \mathrm{ha}^{-}$ ${ }^{1}$ and $875 \mathrm{~m}^{3} \mathrm{ha}^{-1}$ respectively, close to 757 and $879 \mathrm{~m}^{3} \mathrm{ha}^{-1}$ obtained from the calculations from this work.

The relative benefits, from a water resource perspective, in terms of economic value or ecosystem services, can be best seen using the relative variables of water apparent productivity and ecosystem service value per unit of water. Water apparent productivity increased for all land uses in line with the growth in prices. Coffee plantations have the highest water productivity $0.32 \$ \mathrm{~m}^{-3}$ averaged over $2000-2012$, followed by sugarcane, annual crops and orange orchards. So in strict economic terms, the highest returns on water consumption are linked to coffee and sugarcane plantations. On the other hand, annual crops' WAP increased the most by 581\%, over the 379\% and $375 \%$ increase between 2000 and 2012 for coffee and sugarcane plantations respectively. In the year 2012, annual crops' WAP had increased from $0.07 \$ \mathrm{~m}^{-3}$ to $0.43 \$ \mathrm{~m}^{-3}$, higher than the $0.33 \$ \mathrm{~m}^{-3}$ average sugarcane WAP in 2012.

In terms of ES value per unit of water, pastures, natural areas and eucalyptus plantations provide the highest values, an average of $0.0079 \$ \mathrm{~m}^{-3}, 0.0071 \$ \mathrm{~m}^{-3}, 0.0069 \$ \mathrm{~m}^{-3}$ in the study period. Despite the differences in the average values, the variability in the results does not allow to define sharp differences between these land uses (Figure 15). The fact that pastures areas show highest values per unit of water is strongly linked to the fact that pasture ET is lower than that of natural areas, leading to higher runoff. At the same time the difference in average erosion rates between both land uses does not compensate the difference in the 
CHAPTER 5: ECONOMIC AND ECOSYSTEM SERVICES VALUATION OF LAND

AND WATER USE IN BRAZILIAN SUGARCANE UNDER EVOLVING MANAGEMENT PRACTICES AND LAND USE CHANGEINCREASING EFFICIENCY IN ETHANOL PRODUCTION: WATER FOOTPRINT AND ECONOMIC PRODUCTIVITY OF SUGARCANE ETHANOL UNDER EIGHT IRRIGATION LEVELS IN NORTH-EASTERN BRAZILTHE WATER FOOTPRINT ASSESSMENT OF A PAIR OF JEANS: INFLUENCE OF AGRICULTURAL PRODUCTION IN CONSUMER PRODUCT'S SUSTAINABILITY

result of the water provisioning service. Orange orchards have lower values than these land uses, $0.0068 \$ \mathrm{~m}^{-3}$ on average and a smaller range than these land uses. Relative to its water consumption, sugarcane and coffee plantations are not efficient water uses in terms of ES generation, with 0.0035 and $0.0046 \$ \mathrm{~m}^{-3}$ of ES value generated during 2000-2012, despite their improvement over the years.
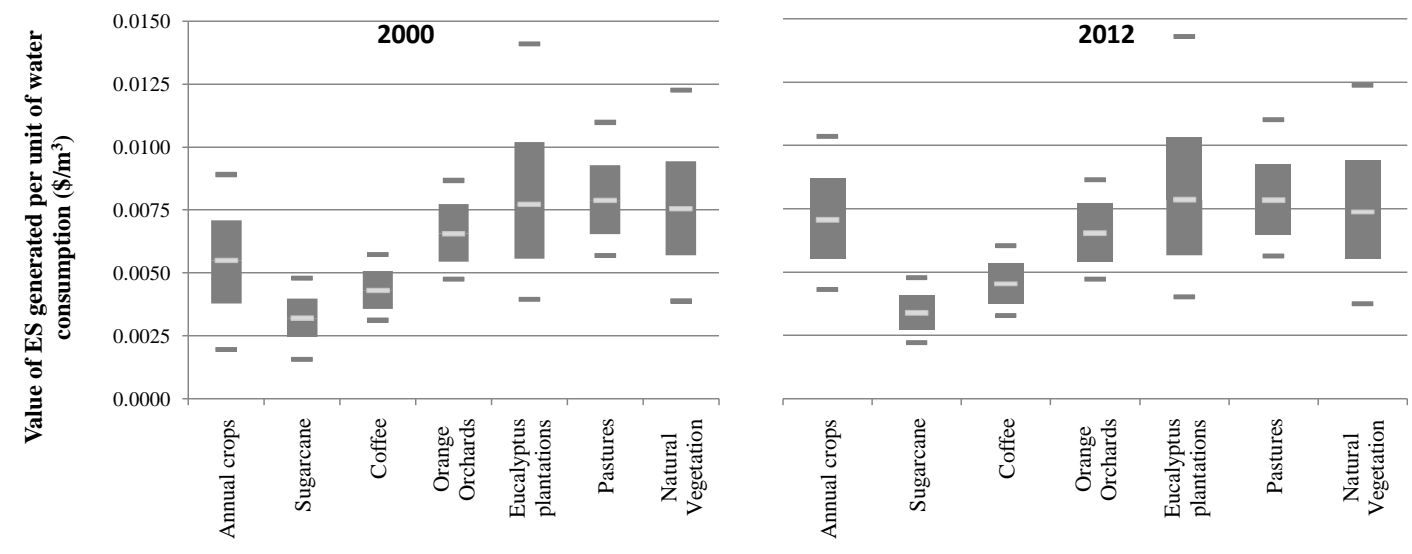

Figure 15.-ES value generated per unit of water (US\$ $\mathrm{m}^{-3}$ ) per land use type for the years 2000 and 2012

As modelled in the present study, the main harvest of annual crops (mostly corn) happens for a good part throughout the summer, the rainy season. The second harvest (mainly soybean) happens during spring and winter, which are drier months than the summer. Therefore, the water provisioning service generation linked to the main crops is higher than to the secondary crops, both in terms of ES value per area or per unit of water consumed. Hence, as the area with secondary crops decreases, the result is that on average, annual crops show higher water productivity values.

A summary of the relative contribution of the land use types at basin level is shown in Table 11, comparing the basin situation in the years 2000 and 2012. Total economic value, WF and value of ES per land use class are correlated with cultivated area development. The total water footprint for all land uses in the basin increased by $12 \%$, from $19,866-23,381 \mathrm{Mm}^{3}$ 
CHAPTER 5: ECONOMIC AND ECOSYSTEM SERVICES VALUATION OF LAND AND WATER USE IN BRAZILIAN SUGARCANE UNDER EVOLVING MANAGEMENT PRACTICES AND LAND USE CHANGEINCREASING EFFICIENCY IN ETHANOL PRODUCTION: WATER FOOTPRINT AND ECONOMIC PRODUCTIVITY OF SUGARCANE ETHANOL UNDER EIGHT IRRIGATION LEVELS IN NORTH-EASTERN BRAZILTHE WATER FOOTPRINT ASSESSMENT OF A PAIR OF JEANS: INFLUENCE OF AGRICULTURAL PRODUCTION IN CONSUMER PRODUCT'S SUSTAINABILITY

year ${ }^{-1}$ to $22,270-24,964 \mathrm{Mm}^{3}$ year $^{-1}$ ( $96 \%$ and $97 \%$ green water footprint, respectively) from 2000 to 2012 as a result of land use changes, mainly as a result of the decrease in pastures and annual crops together with the increase in sugarcane area. The result at the basin level is that average green water consumption per ha increased from $9,081 \mathrm{~m}^{3} \mathrm{ha}^{-1}$ to $9,550 \mathrm{~m}^{3} \mathrm{ha}^{-1}$. 
CHAPTER 5: ECONOMIC AND ECOSYSTEM SERVICES VALUATION OF LAND AND WATER USE IN BRAZILIAN SUGARCANE UNDER EVOLVING MANAGEMENT PRACTICES AND LAND USE CHANGEINCREASING EFFICIENCY IN ETHANOL PRODUCTION: WATER FOOTPRINT AND ECONOMIC PRODUCTIVITY OF SUGARCANE ETHANOL UNDER EIGHT IRRIGATION LEVELS IN NORTH-EASTERN BRAZILTHE WATER FOOTPRINT ASSESSMENT OF A PAIR OF JEANS: INFLUENCE OF AGRICULTURAL PRODUCTION IN CONSUMER PRODUCT'S SUSTAINABILITY

Table 11.-Economic value $\left(\$ 1,000\right.$ year $\left.{ }^{-1}\right), W F\left(\mathrm{Mm}^{3}\right.$ year $\left.{ }^{-3}\right)$, value of water provisioning, Cost associated to erosion $\left(\mathrm{R} \$ 1,000\right.$ year $\left.{ }^{-1}\right)$, average $(a v),. 5^{\text {th }}$ and $95^{\text {th }}$ percentile $(p c)$ values per land use class per land use class in the years 2000 and 2012

\begin{tabular}{|c|c|c|c|c|c|c|c|c|c|c|c|c|c|c|c|}
\hline \multirow[t]{2}{*}{ Land use class } & \multirow[t]{2}{*}{ Year } & \multirow[t]{2}{*}{$\begin{array}{l}\text { Total area } \\
\left(\text { ha year }{ }^{-1}\right)\end{array}$} & \multirow{2}{*}{$\begin{array}{c}\text { Total } \\
\text { economic } \\
\text { value }(\$ 1,000 \\
\left.\text { year }^{-1}\right)\end{array}$} & \multicolumn{3}{|c|}{ Total WF $\left(\mathrm{Mm}^{3}\right.$ year $\left.^{-1}\right)$} & \multicolumn{3}{|c|}{$\begin{array}{c}\text { Total value of water } \\
\text { provisioning }\left(\$ 1,000 \text { year }^{-1}\right)\end{array}$} & \multicolumn{3}{|c|}{$\begin{array}{l}\text { Total erosion costs } \\
\left(\$ 1,000 \text { year }^{-1}\right)\end{array}$} & \multicolumn{3}{|c|}{$\begin{array}{l}\text { Total ES value } \\
\left(\$ 1,000 \text { year }^{-1}\right)\end{array}$} \\
\hline & & & & $5^{\text {th }} \mathrm{pc}$ & $\mathrm{Av}$ & $95^{\text {th }} \mathrm{pc}$ & $5^{\text {th }} \mathrm{pc}$ & $A v$ & $95^{\text {th }} \mathrm{pc}$ & $5^{\text {th }} \mathrm{pc}$ & $A v$ & $95^{\text {th }} \mathrm{pc}$ & $5^{\text {th }} \mathrm{pc}$ & Av & $95^{\text {th }} \mathrm{pc}$ \\
\hline Annual crops & 2000 & 278,324 & 159,352 & & & & & 23,712 & & & 18,124 & & & 5,588 & \\
\hline Sugarcane & 2000 & 950,313 & 864,850 & & 9,713 & & & 19,105 & & 6,834 & 41,564 & 128,864 & $-113,130$ & 22,458 & 12,260 \\
\hline Coffee & 2000 & 64,275 & 114,052 & & 596 & & & 1,324 & & & 418 & & & 905 & \\
\hline $\begin{array}{l}\text { Orange } \\
\text { Orchards }\end{array}$ & 2000 & 164,832 & 120,227 & & 1,397 & & & 4,694 & & & 1,494 & & & 3,200 & \\
\hline $\begin{array}{l}\text { Eucalyptus } \\
\text { plantations }\end{array}$ & 2000 & 105,096 & 24,188 & 930 & 932 & 933 & 3,066 & 3,154 & 3,255 & & 305 & & 2,762 & 2,849 & 2,950 \\
\hline Pastures & 2000 & 628,597 & 176,861 & 4,220 & 4,347 & 4,326 & 25,770 & 26,046 & 26,346 & & 3,592 & & 2,950 & 22,454 & 22,754 \\
\hline $\begin{array}{l}\text { Natural } \\
\text { Vegetation }\end{array}$ & 2000 & 187,525 & 0 & 1,558 & 1,584 & 1,596 & 5,756 & 5,883 & 5,998 & & 59 & & 5,697 & 5,823 & 5,939 \\
\hline TOTAL2000 & 2000 & $2,378,962$ & $1,459,529$ & & 38,606 & & 83,560 & 83,917 & 84,237 & 30,826 & 65,556 & 152,856 & $-72,514$ & 18,362 & 53,056 \\
\hline Annual crops & 2012 & 186,182 & 464,469 & & 516 & & & 7,609 & & & 4,434 & & & 3,175 & \\
\hline Sugarcane & 2012 & $1,295,173$ & $4,412,236$ & & 17,403 & & & 33,078 & & 6,842 & 33,117 & 83,860 & $-51,887$ & -39 & 26,128 \\
\hline Coffee & 2012 & 68,467 & 515,308 & & 823 & & & 1,949 & & & 516 & & & 1,433 & \\
\hline $\begin{array}{l}\text { Orange } \\
\text { Orchards }\end{array}$ & 2012 & 127,825 & 365,293 & & 1,481 & & & 4,824 & & & 1,131 & & & 3,693 & \\
\hline $\begin{array}{l}\text { Eucalyptus } \\
\text { plantations }\end{array}$ & 2012 & 113,136 & 89,356 & 1,335 & 1,337 & 1,339 & 4,213 & 4,328 & 4,460 & & 337 & & 3,876 & 3,991 & 4,123 \\
\hline Pastures & 2012 & 477,928 & 542,067 & 4,249 & 4,392 & 4,364 & 25,829 & 26,137 & 26,473 & & 2,680 & & 23,149 & 23,457 & 23,793 \\
\hline $\begin{array}{l}\text { Natural } \\
\text { Vegetation }\end{array}$ & 2012 & 277,008 & 0 & 2,894 & 2,939 & 2,960 & 10,324 & 10,559 & 10,787 & & 84 & & 10,240 & 10,475 & 10,703 \\
\hline
\end{tabular}


CHAPTER 5: ECONOMIC AND ECOSYSTEM SERVICES VALUATION OF LAND AND WATER USE IN BRAZILIAN SUGARCANE UNDER EVOLVING MANAGEMENT PRACTICES AND LAND USE CHANGEINCREASING EFFICIENCY IN ETHANOL PRODUCTION: WATER FOOTPRINT AND ECONOMIC PRODUCTIVITY OF SUGARCANE ETHANOL UNDER EIGHT IRRIGATION LEVELS IN NORTH-EASTERN BRAZILTHE WATER FOOTPRINT ASSESSMENT OF A PAIR OF JEANS: INFLUENCE OF AGRICULTURAL PRODUCTION IN CONSUMER PRODUCT'S SUSTAINABILITY

TOTAL2012 $2012 \quad 2,545,718 \quad 6,388,728$ $6,388,728$ 28,891 $88,061 \quad 88,483 \quad 88,883$ 
CHAPTER 5: ECONOMIC AND ECOSYSTEM SERVICES VALUATION OF LAND

AND WATER USE IN BRAZILIAN SUGARCANE UNDER EVOLVING

MANAGEMENT PRACTICES AND LAND USE CHANGEINCREASING EFFICIENCY IN ETHANOL PRODUCTION: WATER FOOTPRINT AND ECONOMIC PRODUCTIVITY OF SUGARCANE ETHANOL UNDER EIGHT IRRIGATION LEVELS IN NORTH-EASTERN BRAZILTHE WATER FOOTPRINT ASSESSMENT OF A PAIR OF JEANS: INFLUENCE OF AGRICULTURAL PRODUCTION IN CONSUMER PRODUCT'S SUSTAINABILITY

Pasture areas are the main land use type providing ES, related to water provision and erosion, due to the method used in the ES valuation. However, their area has decreased by 23\%, which is reflected in their lower WF in 2012 as compared to 2000, and the lower value of the ES provided. The decrease in area has been higher than the decrease in ES provisioning. Annual crops' WF in 2012 represented almost half of the initial value, in contrast to natural vegetation, which WF increased from $1,130-2,320 \mathrm{Mm}^{3}$ year ${ }^{-1}$ to 1,768 $-3,494 \mathrm{Mm}^{3}$ year ${ }^{-1}$ in the study period. The increase in natural areas contributes to increasing the provision of ES, diminishing erosion problems and its effect on water quality at the basin level. Eucalyptus, coffee plantations and orange orchards maintained their WF. As a consequence of their limited relevance in terms of area, orange orchards do not appear to be an influential land use class at basin level. Pastures are important activities generating ES value. Their share in total value of ES generated is higher than their share in area. This is related to their low potential erosion rate.

At the field level, there have been two relevant developments in the study period: the change of sugarcane to mechanized harvesting and the decrease of annual crops' second harvest. Although both developments represent an improvement in ES generation per unit of water $\left(\$ \mathrm{~m}^{-3}\right)$ and area $\left(\$ \mathrm{ha}^{-1}\right)$ only the change ins sugarcane mechanization has had an effect at the basin level. As sugarcane represents almost $50 \%$ of the cultivated area in the basin, the sugarcane erosion rate is the most relevant factor affecting the value of land and water ES in the MGP basin. The mechanization of sugarcane harvesting has lowered erosion potential of this crop, and thus helped to balance the negative effects of its expansion in terms of area cultivated over pastures. The evolution of annual crops' second harvest, though relevant at the field level, has had little effect in the basin average results. The extension of mechanized harvesting has allowed for a decrease in the erosion levels.

The resulting ES values per unit of water are two orders of magnitude lower than the resulting water apparent productivities. This implies that, given the selection of ES used in this work, water consumption for the sole purpose of ES generation is significantly less productive than the water consumption for the purpose of direct economic revenues. Both evaluations are complementary and address different spheres for water valuation. The use of 
CHAPTER 5: ECONOMIC AND ECOSYSTEM SERVICES VALUATION OF LAND

AND WATER USE IN BRAZILIAN SUGARCANE UNDER EVOLVING

MANAGEMENT PRACTICES AND LAND USE CHANGEINCREASING EFFICIENCY IN ETHANOL PRODUCTION: WATER FOOTPRINT AND ECONOMIC PRODUCTIVITY OF SUGARCANE ETHANOL UNDER EIGHT IRRIGATION LEVELS IN NORTH-EASTERN BRAZILTHE WATER FOOTPRINT ASSESSMENT OF A PAIR OF JEANS: INFLUENCE OF AGRICULTURAL PRODUCTION IN CONSUMER PRODUCT'S SUSTAINABILITY

land and water apparent productivity allows us to evaluate the economic benefits of land and water use, mainly to support decision making of the owner of the land. ES valuation helps us evaluate the costs and benefits of water and land use in relation to other river basin stakeholders.

\subsection{Conclusions}

The current analysis relates the WF of sugarcane production in the MGP river basin to economic indicators. In particular we build on the idea proposed in Tadeu (2014) of using ES in combination with WF assessment by applying it for the evaluation of the water productivity in economic terms and through the inclusion of the valuation of ES. The objective of such an assessment is to include a valuation of the externalities linked to land uses and green water use. The approach applied in this study therefore provides an evaluation of economic sustainability in relative terms between dominant land uses in an area, including natural areas.

The results vary significantly due to the high range of erosion rates accounted for, in sugarcane (both in manual and mechanical harvesting) and the rest of the uses. The MonteCarlo analysis served to assess the variability in the results and test their robustness to the wide range of erosion rates extracted from the literature. In the case of the estimation of water consumption from eucalyptus, pastures and natural areas, the results do not show important differences. However, the effect on the estimation of the ES generated is relevant. This is related to their very low erosion costs and low water provisioning service generated.

The results obtained are also dependent on the selection of ES taken into account. In this case, we have focused on two ES most closely related to the hydrological cycle. One important service that is not taken into account here is regulation of the hydrological cycle which can affect base and minimum flows regimes and flood risk control. Moreover, other sorts of services not related to water have not been considered.

Sugarcane is the dominant land use in the MGP river basin. Its cropping area is increasing mostly into over pasture and field crop areas. However, while sugarcane is more profitable, 
CHAPTER 5: ECONOMIC AND ECOSYSTEM SERVICES VALUATION OF LAND

AND WATER USE IN BRAZILIAN SUGARCANE UNDER EVOLVING

MANAGEMENT PRACTICES AND LAND USE CHANGEINCREASING EFFICIENCY IN ETHANOL PRODUCTION: WATER FOOTPRINT AND ECONOMIC PRODUCTIVITY OF SUGARCANE ETHANOL UNDER EIGHT IRRIGATION LEVELS IN NORTH-EASTERN BRAZILTHE WATER FOOTPRINT ASSESSMENT OF A PAIR OF JEANS: INFLUENCE OF AGRICULTURAL PRODUCTION IN CONSUMER PRODUCT'S SUSTAINABILITY

it has both a lower water apparent productivity and ES value per unit of water than other land uses in the river basin, coffee orchards and field crops, and all other land uses in terms of ES value per unit of water. The results show that sugarcane is not the most efficient land use type from a water resources perspective, despite its relatively improvement in terms of ES over time.

The land use changes that occurred in the basin led to higher economic revenues from water use, but to a decrease in the value of the services provided per unit of water consumed. The net effect of changes in sugarcane production both in management practices and expansion is shown to depend also on the relative substitution of the crop over other land uses. The resulting effect at basin level from the land use changes is dependent on the relative performance between land uses, which in turn is conditioned by specific management options. The evolution from pastures or annual crops to sugarcane areas may improve the economic returns on water use in the first case or decrease them in the latter, but the effects on the provision of ES linked to the hydrological cycle will be negative, and very dependent of the sugarcane erosion rates.

The sucro-bioenergy sector has, through the introduction of the sugarcane burning phase-out, greatly improved its performance in relation to water resources and lead the improvement in the average results at the basin level. The large share of the basin area cultivated with sugarcane leads to the situation that small changes in this sensible sector may result in substantial environmental benefits for the basin.

Therefore, public policies or private initiatives aiming at improving the environmental conditions of the basin should particularly aim at improving the performance of the sugarcane sector, specifically erosion rates in mechanized harvesting. This may be done by promoting less impacting management practices, but also by de-incentivizing sugarcane growth into areas such as pastures or natural areas that offer better performing indicators and avoid deforestation. This could be done through the limitation on the public support to investments, fiscal measures or even command and control approaches. Instruments of public policy like sugarcane agro-ecological zoning could incorporate a basin-wide vision of the impact on the hydrological cycle. Nevertheless, the best policy choice will depend on 
CHAPTER 5: ECONOMIC AND ECOSYSTEM SERVICES VALUATION OF LAND AND WATER USE IN BRAZILIAN SUGARCANE UNDER EVOLVING MANAGEMENT PRACTICES AND LAND USE CHANGEINCREASING EFFICIENCY IN ETHANOL PRODUCTION: WATER FOOTPRINT AND ECONOMIC PRODUCTIVITY OF SUGARCANE ETHANOL UNDER EIGHT IRRIGATION LEVELS IN NORTH-EASTERN BRAZILTHE WATER FOOTPRINT ASSESSMENT OF A PAIR OF JEANS: INFLUENCE OF AGRICULTURAL PRODUCTION IN CONSUMER PRODUCT'S SUSTAINABILITY

local factors and alternative land uses and falls out of the scope of the present work. Using such a strategy the trade-offs of changing land uses could also be considered. 


\section{CONCLUSIONS OF THE RESEARCH}

\subsection{General conclusions of the work and research contributions}

The present research contributes to the field of evaluating the environmental performance of agricultural production in terms of water use efficiency and sustainability. Three case studies of industrial crops production are selected and the main drivers of their production are analysed to understand how the resulting change in agricultural practices has impacted on crop water use efficiency. It deepens the understanding of the definition of water use efficiency and sustainability in agriculture. The research shows the need for evaluating the influence of the drivers of agricultural production, in particular the environmental and agricultural policies, in such performance results. The increased demand for agricultural products has implications at the river basin scale, shaping agricultural production practices and land use change. The research highlights the complexities of the agricultural sector and its relation with the land use and the hydrological cycle in order to assess sustainability of water use. The work presented also deals with the question of the scale of analysis to assess water use efficiency, from the field to the basin scale in order to feed into the global discussion. The research points out the need of identifying trade-offs in the development of agricultural productions.

\subsubsection{Chapter 3: Increasing efficiency in ethanol production: Water footprint and economic productivity of sugarcane ethanol under 8 different water regimes in North-eastern Brazil}

The results from this chapter show that the largest share of ethanol water footprint lies in the agricultural stage with industrial phase of sugarcane processing representing only $1 \%$ of the total water footprint. In agricultural production stage, results show how irrigation increasingly improves the economic and physical green, blue and grey water productivity. If the grey water footprint is also taken into account the total water footprint is smallest in rainfed production, with an average of $1,6471^{-1}$ of ethanol than in low irrigation levels. Nevertheless, since rainfed areas showed the lowest yields they provided the lowest economic profits and water apparent productivity. The next lowest total water footprint was found in the case of full irrigation, 1,758 $11^{-1}$ of ethanol, despite having the highest total blue 
water consumption and grey water footprint. The use of the vinasse as fertigation further reduced the grey water footprint as compared to areas in which vinasse is not applied.

Production under rainfed and lower water regimes, including rainfed production, provides less profit per cultivated area than higher water regimes and full irrigation while also show lower water apparent productivity. This increased profit per ha explains the increase in irrigated areas and would support it also from the perspective of water resources. As irrigation volumes increase, the water use efficiency also increases, in physical and economic terms, both for the blue as for the green components of the water footprint. This result, however, come at the expense of an increased blue water use per cultivated area and higher grey water footprint, potentially adding further pressure from pollution on the receiving water bodies.

These conclusions, however, are based only on the field scale assessment. In order to avoid rebound effects, the evaluation of local blue water scarcity that assesses total water footprint against water availability at the river basin level would be needed. In an area where water resources are scarce, in order to optimize water and land productivity at the sugar-mill level. areas with high irrigation volumes or full irrigation systems would need to coexist with rainfed production or areas with low irrigation regimes

Continued demand for biofuels will probably support the increase in sugarcane production. As irrigation and fertilization applications grow, potential externalities of water consumption and pollution may arise, which would also need to be analysed. This is particularly relevant in a semi-arid area where the infrastructure for water management, urban supply and wastewater treatment is limited. On the other hand, the increased land and water productivity may open the way for the maintenance of natural vegetation areas by lifting the pressure to expand cultivated area over the local tropical rainforest.

\subsubsection{Chapter 4: The water footprint assessment of a pair of jeans: Influence of agricultural policies in consumer product's sustainability}

In comparison to cellulose-based fibres, mostly based on green water resources, cottonbased products show a higher total water footprint considering both the fibre production and the industrial stages. Whereas the average water footprints of lyocell fibres were 1384, 34.5 and $35.3 \mathrm{~m}^{3} \mathrm{t}^{-1}$ cotton, the green, blue and grey water footprints were 263, 2767 and 203 
$\mathrm{m}^{3} \mathrm{t}^{-1}$ respectively. The cotton-growing phase has a higher share of the total product water footprint than the industrial phases.

Results show a wide variability between municipalities and irrigation methods. This variability forms the basis for the design of responses for product's water footprint reduction.

The reduction in price incentives for cotton production after CAP reform and the minimization of variable costs led to lower irrigation, fertilizer and herbicides application, which resulted in lower yields and higher water footprints, including grey water footprints. Variability of crop WF was higher in the year 2005 than in 2009, linked to the different behaviour exhibited by farmers. This shows how intensification of production, with a more complex crop management, can lead to higher water productivity and economic returns.

The results at field level differ from the results at the basin level. Although unit water footprints increased in 2009, the reduction of the cotton surface decreased cotton's water footprint in the area. The total green water footprint decreased from 35 to $27 \mathrm{Mm}^{3}$, the blue water footprint from 455 to $197 \mathrm{Mm}^{3}$ and grey water footprint from 32 to $15 \mathrm{Mm}^{3}$.

However, when evaluating the basin sustainability, blue water scarcity is only weakly connected to cotton production in this area. Cotton's blue water footprint decreased from $21 \%$ to $7 \%$ of crop blue water footprint in the study area, while blue water scarcity did not vary significantly. Hydrological infrastructure management conditioned blue water availability and the maintenance of environmental flows, thus determining blue water scarcity in the basin. In this regard, textile companies willing to contribute to the sustainability of cotton production need to consider the drivers of cotton water use and crop management, as well as the general trends of the river basin. Increasing cotton water productivity and irrigation efficiency is only part of the answer to more sustainable products. In this case, the effects of the CAP over crop management was the main driver behind product efficiency, and hydrological management the main driver behind river basin sustainability. Ultimately, changing CAP measures for cotton production in the Guadalquivir river basin resulted in significant changes in the water footprint of cotton-made jeans. 


\subsubsection{Chapter 5: Economic and ecosystem services valuation of land $\&$ water} use in Brazilian sugarcane under evolving management practices and land use change

São Paulo state in Brazil is one of the global leaders in sugarcane production, based on highly productive, rainfed system. Environmental legislation to decrease $\mathrm{CO}_{2}$ emissions, protect air quality and respect natural vegetation in riparian areas has promoted a mechanization of the harvesting tasks and the phasing out of the practice of burning the fields before manual harvest. The cultivated area in the state has increased continuously, mostly at the expense of pastures and annual crops. We analyse how these processes have affected water use efficiency and the trade-offs in terms of the provision of two land and water ES, water provisioning and erosion.

Water apparent productivity in sugarcane has increased in the period from 0.09 to 0.33 $\$ \mathrm{~m}^{-3}$ linked to the sugarcane price increase. However, the increase in ES value generation is unclear as there is a high variation in the results linked to the sugarcane erosion rates in mechanical and manual harvesting. The ban on sugarcane burning and the introduction of mechanical harvesting have improved sugarcane average ES value generation by $4 \%$. Uncertainty in the estimation has also decreased, as the difference between higher and lower percentiles of the estimation decreased. Standard deviation of the estimations decreased a 66\% between 2000 and 2012 .

The evaluation of the rest of the land uses in the river basin, including natural areas, shows how sugarcane does not constitute the land use with the highest water apparent productivity and neither the highest ES generation per unit of water. Annual crops and coffee orchards show higher water apparent productivity and the value of ES per unit of water is higher in all other land uses. Sugarcane increase at the expense of pasture and annual crops would imply lower basin average water apparent productivity and the increases in the value of ES generation per unit of water if sugarcane substitutes annual crops and decreases if it substitutes pastures. These results are highly dependent on the sugarcane erosion rates range showing ample variability. As for the other land uses, coffee orchards have the highest water apparent productivity, whereas pastures, eucalyptus plantations and natural areas would show highest ES generation per unit of land and water, with similar average results between them.

However, this analysis is also dependent on the selection of ES considered. In this work we have focused on two specific land and water services. However, the inclusion of other services could affect the obtained ES values per unit of water. Nevertheless, they show how 
the inclusion of ES adds a further perspective regarding the efficiency of water use and the valuation of externalities of land use change and water consumption. It also shows the tradeoff existing between optimizing land and water use in terms of market value or ES value generation.

The perspective adopted here shows how efficiency of water consumption linked to a particular production can be put in perspective when considered in the context of other land uses in the area and temporal trends are also considered. It also shows how the improvement in environmental policy related to environmental and health issues also has effects over the river basin water use. Changes in sugarcane management practices, linked to the dominance of this crop in the basin implies that changes in this sector have direct and strong implications for basin water use and its efficiency.

\subsection{Final considerations}

The research makes a progressive analysis first from the field perspective, to the field and basin perspective and finally only at the basin level. The starting point of the present research was the product perspective, ethanol in two chapters or a pair of jeans in the second chapter. This approach was selected to reflect the perspective of the economic system, which is focused on products. This perspective is used by traders, companies, consumers and other stakeholders of the value chain. When these stakeholders approach the question of sustainability, their main point of view is the product perspective. However, as we have shown in the present research, this perspective can be incomplete, not providing the full set of necessary information to assess and address sustainable production.

The results could point to three cases of sustainable intensification showing better performance indicators of water use efficiency, be it in physical or economic terms as production is intensified. This would be aligned to the idea of ecological modernization (Mol and Spaargaren, 2000): all case studies represent examples of changing production systems in which an increase in a set of production factors led to higher water efficiency. These factors included decrease of manual labour, capital investments, increased in mechanized operations for tillage, changes in fertilizer and pesticide application rates and in harvesting techniques. In the first example, as irrigation levels increased in sugarcane production in North-east Brazil, both physical and economic water productivity also increased, both for 
blue and green water. In the second example, when the economic incentives from CAP ceased for cotton production in the Guadalquivir river, farmers cut down on variable costs and decreased the application of fertilizer and pesticides. This lead to lower yields and lower water use efficiency. In the third case, introduction of agri-environmentally measures to decrease $\mathrm{CO}_{2}$ emissions and negative effects on air quality in sugarcane cultivation in SP state, the introduction of mechanized harvesting resulted in an improvement in water use efficiency.

Nevertheless, there are some questions on the actual consequences of such improvements at the basin level. In the first case, as was discussed in the previous section, the field scale of analysis does not show the implications of the increased irrigation levels over water availability at the basin level, nor does it inform us of possible coupled land use changes. There is also a higher pollution potential reflected in the higher grey WF. The second case, shows how the sustainability of water use is not linked to a specific production, cotton in this case, but to the aggregation of all demands over the hydrological management in a highly-regulated river basin, reinforcing the need to analyse the context to be able to assess the sustainability of a certain production. In the third case, the argument is made how the efficiency of water use in sugarcane is also relative to the efficiency of the rest of the land uses in the river basin. Despite the positive effects of sugarcane results, other existing land uses show better indicators. Land use changes led to lower water use efficiency at the basin level, considering also the perspective of potentially negative externalities.

In addition to this, despite improvements, water use efficiency can also be considered in relation to the rest of land uses in an area. This way the most efficient water and land use (as one that brings the highest societal benefits) is identified, opening the way for analysis of implications of land use change. Classifying a certain water use as efficient is dependent on the definition of the term, which is related to the indicator used in the numerator of the equation. For example, in chapter 5 we have shown how some of the land uses, i.e. coffee orchards or sugarcane were efficient water uses if terms of economic value generation, but in terms of water ES provision were not the most efficient land and water uses. The opposite was shown to be the case for pastures, eucalyptus plantations and natural areas. Indicators can contribute to answering the question of which is the most efficient use of land and water and open the way for the participation of other stakeholders.

While physical or economic efficiency of water use can be increased through the improvement of management practices, the effect of such improvements at the basin level 
still needs to be analysed. Sustainable water use is defined at the basin level, by the evaluation of all the uses in the basin against the existing supply. Efforts aimed at improving the environmental perspective of products should consider this change of dimension. It is challenging for stakeholders outside the immediate sphere of production to deal with this change of perspective. Complex situations in which several factors are relevant and affect the overall results are difficult to convey in a meaningful way to traders, companies and consumers. It is for this reason that indicators like the WF and methodologies like the WFA, though not exhaustive, can help to convey this complexity to non-specialist audiences. While not all trade-offs could or should be included in a valuation analysis, (for example cultural value of water uses or intrinsic value of ecosystems) they certainly should be considered in the governance process and decision-making at all levels. Nevertheless, the inclusion of a part of ES in the valuation, contributes to considering the implications of agricultural management and land use changes in water management for direct and for indirect stakeholders. 


\section{LIMITATIONS AND AVENUES FOR FURTHER RESEARCH}

The present research an attempt to look into the efficiency of water and land use in agricultural productions under changing management practices, and discuss its implication for the evaluation of the sustainability of water use in agriculture. However, the research presents a number of limitations, methodological and conceptual that will be discussed:

\subsection{Methodological limitations}

- Methodologically, crop water footprint in all three chapters 3, 4 and 5 has been estimated based on the approach in Allen et al.(2006) using the software CROPWAT (FAO, 2009). This software estimates crop green and blue evapotranspiration. However, crop water yields were obtained from company data or national statistics and not modelled. Conversely, crop ET was modelled and not measured. This may render higher water footprints as crop actual ET can be lower than the modelled in CROPWAT which assumes optimum crop conditions. This caveat is inherent to the utilization of the model.

- Moreover, in the calculation of the grey water footprint in chapter 3 the leaching factor has been assumed to be constant and taken as an indicative value of $10 \%$ of the applied nitrogen rates in absence of better data. In chapter 4 the estimation of this rate was improved assuming a constant $15 \%$ of the surplus nitrogen after accounting for crop nitrogen extractions. Nevertheless, in semi-arid environments nutrient leaching is determined not only by fertilizer practices but also by irrigation practices and the interaction between both. The use of more complex crop models that integrate both water and nutrient cycling could improve this issue and provide more robust results.

- In chapters 4 and 5 the lack of data for production costs in the activities led to water economic productivity being calculated solely based on the market value of production. Moreover, in all three case studies water has been valued in average terms, not at marginal valuation, that can guide decision-making in the face of scarcity.

- In chapter 5 the calculation of ES value does not consider hydrological regulation of the land uses, thus evaluating the impact of land use changes in an intra-annual 
basis. Such valuation can be very relevant and modify the results. Furthermore, the selection of ES is limited to twos specific water and land provisioning services. It does not consider other non-water related services, like climate regulation, biodiversity or carbon storage or cultural values. Another important caveat of the present analysis is that it did not fully consider the spatial distribution of the land uses to estimate the ES analysed. Water provisioning and erosion processes are related to geographic characteristics, like slope and slope length. In this study this caveat was addressed through the use of continuous functions for the erosion rates in the Monte-Carlo analysis.

- In chapter 5, only annual averages were available for climate data, precipitation and ETo. Consequently, the calculation of crop's ET was constant in all years, against varying yields and crop unit WF $\left(\mathrm{m}^{3} \mathrm{t}^{-1}\right)$ varied according to yield increase or decrease. This prevented us also from evaluating the variability between years of defining variables like crop ET and water provisioning $\left(\mathrm{m}^{3} \mathrm{ha}^{-1}\right)$.

- In chapter 5 , we were not able to sufficiently consider intensification in other productions like orange orchards and coffee plantations. There is an indication in IEA statistics of increased tree density in orange and coffee, a relevant process that can greatly determine water use and ES provision in these areas. Both production systems are undergoing a process of intensification with denser plantations, and growth of irrigated area and irrigation volumes. However available data did not allow for its integration in the analysis in a coherent way. In pasture areas, where there are also indications of an intensification process with better management of pastures, extension of fertilization practices and increased stocking rates, we were able to introduce this analysis indirectly, through the separation of natural and managed pastures.

- The analysis presented in this research, being focused on water use efficiency, has not entered into the full evaluation of green, blue and grey water footprint's sustainability simultaneously. An evaluation of green water scarcity and water pollution levels can contribute to the full picture of the implications for water resources of agricultural production developments. 


\subsubsection{Conceptual limitations of the research}

As any research, the present thesis is based on some unconscious choices and a personal world view. Therefore:

- The approach used in the present research is above all water-centred. At the farm level water is one among several production factors. Actually, this has been the analysis considered in chapter 4. Farmers optimize the whole set of factors, including land, labour, capital, but also uncertainty and risk. In this regard, favouring highest water efficiency, may lead to inefficiencies in the use of other factors and most importantly, to the implementation of strategies too costly to the farmer or not possible to implement under existing social and institutional conditions.

- In chapter 2, a definite definition of sustainable water use is employed. However, sustainability is regarded by some authors as a societal choice and not an absolute value. It would be an ideal to aim for, instead of a white/black definition. Several trade-offs appear in all human interventions in the environment, and the choice between different options can be regarded as a matter of social priorities. Moreover, balancing demands implies restructuring the frequently opposed interests of different users, which raises the question of how to do so in a fair way. Management of environmental resources necessarily involves managing human interventions and the varied interests of stakeholders and communities, intra- and inter-generational. In this regard, decisions, even when backed by scientific information, involve underlying value judgements and can be considered political. In this thesis, particular stress is laid on the concepts of physical and economic efficiency of water use and the relevance of such analyses has been argued. Nevertheless, some authors question such analyses with the argument that they do not consider the power relations and inequalities involved, or the different understandings of efficiency.

- At a higher level, there may be social gains from using water above the sustainable level or promoting land uses that are not the most efficient allocation. We have addressed this issue through the consideration of ES in chapter 5, but have not looked in depth at the possible mechanisms to deal with the trade-offs .

- Conceptually, the approach to ES valuation used in chapter 5 assimilates the services from both crops, forestry and natural areas in the same way. The 
consideration of provisioning services is contested by some authors that stress the definition of ES as the services provided by natural areas. With this perspective, the valuation of ES generation from cropland and plantations should not be analysed together with that of natural areas. Natural areas have an intrinsic value that should not be made equivalent to the rest of uses, since natural capital is not interchangeable with human capital. In the framework of the Water Footprint Assessment methodology this argument could be applied through the green water scarcity index and its evaluation.

\subsection{Avenues for further research}

Throughout the present work we analysed three cases of agricultural intensification (or the opposite in chapter 4). As discussed in the previous section, we have seen the need to analyse not only the gains in water use efficiency but also the aggregated effect of all land uses in the river basin to understand the full implications of water use in the basin, that is, if water is used more or less efficiently and sustainably. This applies to blue water, but also to water pollution (grey water footprint and water pollution levels) or green water (green water footprint and green water scarcity). The assessment of green water scarcity is challenging, derived from the difficulty in evaluating environmental green water requirements (Hoekstra et al., 2011). Environmental green water requirements could be informed through the ES concept.

The evaluation of green water scarcity could be particularly interesting in the study of chapters 3 and 5 , where there is an indication that the productivity increases of sugarcane have contributed to the increased compliance with the forest code. This code specifies the legal requirements for the protection of natural areas in private lands $(20 \%$ of cultivated area in São Paulo and Alagoas states) and permanent protection areas (APP, riparian forests and vegetation around water springs and hilltops). In addition to this, the increased intensification could eventually lead to social gains in terms of employment rates and quality in the production areas, but also indirect social gains. In the case study of chapter 3 , the sugar mill lent the field nearer to the villages to the local population for bean cultivation on the land lying fallow between sugarcane renovations, instead of their common practice of cultivating non-edible leguminous crops more efficient in nitrogen fixation. A similar practice was used in allowing fishery activities in irrigation reservoirs. Future research could make a more 
comprehensive analysis of environmental, economic and social sustainability of such transition to irrigation practices.

Another derived line of research is the improvement in the understanding of how intensification of some productions leads or does not lead to land use changes and to intensification of other productions. In particular, in chapter 5, the perceived trend in intensification in orange orchards, coffee plantations and pasture areas could be interrelated with sugarcane development and annual crop cultivations. In this regard, the study of the relationship between intensification in several productions and land use changes in an area can lead to a better understanding of the processes that govern land and water management and provide information for nature conservation and rural development policies. 


\section{REFERENCES}

AAA (2010) Agencia Andaluza del Agua. Plan hidrológico de la Demarcación Hidrológica de Guadalete y Barbate. [online, Accessed on August 2012]

Aguiar, D. A., Rudorff, B. F. T., Silva, W. F. A., Adami, M., Mello, M. P. (2011) Remote Sensing Images in Support of Environmental Protocol: Monitoring the Sugarcane Harvest in São Paulo State, Brazil. Remote Sens. 3, no. 12: 2682-2703.

Aldaya MM, Llamas MR (2008) Water footprint analysis for the Guadiana River Basin, Value of Water Research Report Series No. 35. UNESCO-IHE, Delft, Netherlands

Allan, J.A. 2003. Virtual water - The water, food, and trade nexus: Useful concept or misleading metaphor? Water International 28(1): 106-112.

Allen, R.G., Pereira, L.S., Raes, D. and Smith, M. (2006) Crop evapotranspiration Guidelines for computing crop water requirements - FAO Irrigation and drainage paper 56. Food and Agriculture Organization. Rome, Italy. [online, Accessed on August 2012] Available at: www.fao.org/docrep/X0490E/X0490E00.htm

Alliance for Water Stewardship (2012). International Water Stewardship Standard. First draft for stakeholder input. Version 03.13.2012. [online, Accessed on August 2012] Available at: www.allianceforwaterstewardship.org/assets/documents/AWS_Standard_First_Draft_v_0 3_13_2012.pdf

Almeida, B.A.D.L., Barreto, G.F.B., Gonçalves, C.M.N., 2007. Resíduos da Agroindustria Canavieira no Estado de Minas Gerais: usos e conservação ambiental. Informe Agropecuário, v. 28, n. 28, p. 96-100.

ANA. Agencia Nacional de Aguas 2009. Manual de Conservação e Reúso de Águia na Agroindustria Sucoroenergética. Agência Nacional de Águas; Federaçao das Industrias do Estado de São Paulo; União das Indústria da Cana-de-açúcar; Centro de Tecnologia Canavieira. -- Brasília.

Andrade Junior, A.S., Bastos, E.A., Aguiar Neto, A.O., Braga, D.L., Silva, M.E., Noleto, D.H. 2012 Agricultural water footprint of ethanol and sugar from sugarcane under fertigation production system. In: Proceedings of XVIIIth World Congress of the International Commission of Agricultural and Biosystems Engineering (CIGR), Valencia, Spain, (CD-ROM).

Andrade, D. C. (2010) Modelagem e valoraçao de serviços ecossistêmicos: uma contribuçao da economia ecologica. PhD. Thesis. Instituto de Economia da Universidade Estadual de Campinas (UNICAMP). Campinas, Brazil.

Arriaza, M. (2008) Progressive extensification of the cotton production in Spain In Proceedings of International Cotton Conference "Rationales and Evolution of Cotton Policies", 50-55.

Arriaza, M. Capellán H. (2009). Effects of the Cotton Reform in Spain. Cahiers Agricultures Vol. 18 No. 5 pp. 408-416 ISSN 1166-7699 
Bajay, S.V., Ferreira, A.L., 2005. A energia da biomassa no Brasil. In: Rosilho-Calle, F., Bajay, S.V., Rothman, H. Uso da Biomassa para produção de energia na indústria brasileira. Campinas: Editora Unicamp, cap. 2, p. 68 - 120.

Bayart, J-B, Bulle, C., Deschênes, L., Margni, M., Pfister, S., Vince, F., Koehler, A. (2010) A Framework for Assessing Off-stream Freshwater Use in LCA. The International Journal of Life Cycle Assessment 15 (5) (March 31): 439-453.

BCI (2012) Better Cotton Initative [online, Accessed on August 2012] Available at: bettercotton.org/

Beltran, M., Velazquez, E., (2015) The Political Ecology of Virtual Water in Southern Spain, International Journal of Urban and Regional Research 39, Issue 5 1020-1036

BLFUW, (2000a) Bundesministerium für Land- und Forstwirschaft, Umwelt und Wasserwirstchaft. Veordnung über die Begrenzung von Abwasseremissionen aus der Herstellung von Chemiefassern (AV Chemiefassern). Bundesgesetzblatt 18. Juli 2000

BLFUW, (2000b) Bundesministerium für Land- und Forstwirschaft, Umwelt und Wasserwirstchaft. Veordnung über die Begrenzung von Abwasseremissionen aus der Herstellung von gebleichtem Zellstoff (AEV Gebleichter Zellstoff). Bundesgesetzblatt 18. Juli 2000

Boelens, R., Vos, J., (2012) The danger of naturalizing water policy concepts. Water productivity and efficiency discourses from field irrigation to virtual water trade. Jnl. Agricultural Water Management 108:16-26.

Brown, S., H. Schreier and L. M. Lavkulich (2009). Incorporating Virtual Water into Water Management: A British Columbia Example. Water Resources Management 23: 2681-2696.

Bryan, B. A. (2013) Incentives, land use, and ecosystem services: Synthesizing complex linkages. Env. Science \& Tec. 27

Buarque, D.C., Pedrosa, V.A., Carvalho, G.S.C., Freire, C.C. 2003. Critérios de Demandas Hídricas para a Outorga de Uso da Água: Setor Sucro-Alcooleiro. In: XV Simpósio Brasileiro de Recursos Hídricos, 2003, Curitiba/PR. Anais XV Simpósio Brasileiro de Recursos Hídricos. São Paulo.

Bulsink, F., Hoekstra, A.Y. and Booij, M.J. (2010) The water footprint of Indonesian provinces related to the consumption of crop products, Hydrology and Earth System Sciences, 14(1): 119-128

Godfray, J.R. Beddington, I.R. Crute, L. Haddad, D. Lawrence, J.F. Muir, J. Pretty, S. Robinson, S.M. Thomas, C. Toulmin (2010), Food security: the challenge of feeding 9 billion people Science, 327pp. 812-818.

Camargo, O.A. de., Valadares, J.M.A.S., Geraldi, R.N. 1983 Características químicas e físicas de solo que recebeu vinhaça por longo tempo. Boletim Técnico IAC. Instituto de Agronomia de Campinas, Campinas. SP (36). 30p.

Cavero, J., R. Barros, F. Sellam, S. Topcu, D. Isidoro, T. Hartani, a. Lounis, et al. 2012. "APEX Simulation of Best Irrigation and N Management Strategies for Off-site N Pollution 
Control in Three Mediterranean Irrigated Watersheds.” Agricultural Water Management 103 (January): 88-99.

Cazcarro, C., Duarte, R., Sánchez-Chóliz, J., Sarasa, C., Serrano, A (2014) Environmental Footprints and Scenario Analysis for Assessing the Impacts of the Agri-Food Industry on a Regional Economy: A Case Study in Spain. Journal of Industrial Ecology 19(4)

CCEE. 2012. Câmara de Comercializaçao de Energia Elétrica. [online] Accessed on March,2013. Available at: ccee.org.br

CEOWM (2012) Water Assessment Methods. [online, Accessed on August 2012] Available at: ceowatermandate.org/water-assessment-tools-methods/)

CEPEA/USP. 2013. Centro de Estudos Avanzados em Economia Aplicada. Indicador dos preços de açúcar e álcool. 2011. [online] Accessed September 2013. Available at: www.cepea.esalq.usp.br.

Chapagain, A. K. and S. Orr (2009). An improved water footprint methodology linking global consumption to local water resources: A case of Spanish tomatoes. Journal of Environmental Management 90(2): 1219-1228.

Chapagain, A K, A Y Hoekstra, H H G Savenije, and R Gautam. 2005. "The Water Footprint of Cotton Consumption: An Assessment of the Impact of Worldwide Consumption of Cotton Products on the Water Resources in the Cotton Producing Countries." Ecological Economics 60.

Chenoweth, J., M. Hadjikakou and C. Zoumides (2014). Quantifying the human impact on water resources: a critical review of the water footprint concept. Hydrol. Earth Syst. Sci. 18(6): 2325-2342.

Chico, D.; Aldaya, M.M.; Garrido, A.; Llamas, M.R. and Salmoral, G. (2010)The water footprint and virtual water exports of Spanish tomatoes. Papeles de Agua Virtual. Número 8. Fundación Botín.

Chouchane, H., Hoekstra, A., Krol, M. Mekonnen, M. (2015) The water footprint of Tunisia from an economic perspective. Ecological Indicators 52, 311-319.

Chukalla, A.D., Krol , M.S. and Hoekstra, A.Y. (2015) Green and blue water footprint reduction in irrigated agriculture: Effect of irrigation techniques, irrigation strategies and mulching, Hydrology and Earth System Sciences, 19(12): 4877-4891

Cotton Outlook (2012) A- Index. Average world prices. [online, Accessed on August 2012] Available at: www.cotlook.com/

CPRM. 2005. Serviço Geológico do Brasil. Diagnostico do Município de Senador Teotônio Vilela, Estado de Alagoas. Org. Mascarenha, J.C., Beltrao, B.A., Junior, L.C.S.

CTA; GSI-LAC; COSUDE; IDEAM, (2015). Evaluación Multisectorial de la Huella Hídrica en Colombia. Resultados por subzonas hidrográficas en el marco del Estudio Nacional del Agua 2014. Medellín, Colombia.

Cucek, L., Klemes, J.J., Kravanja, Z. 2012. A review of a Footprint analysis tools for monitoring impacts on sustainability. Journal of Cleaner Production, v. 34, p. 9-20. 
Dalin, C., Konar, M., Hanasaki, N., Rinaldo, A., Rodriguez-Iturbe, I. (2012) Evolution of the global virtual water trade network. PNAS, 109, 21

Daniel, M.A., Sojamo, S. (2012). From risks to shared value? Corporate strategies in building a global wáter accounting and disclosure regime. Water Alternatives, 5:3, 636-657.

Davis, A. M. Thorburn, P.J. Lewisa, S.E. Bainbridge, Z.T. Attard, S.J. Milla, R. Brodie J.E. 2013. Environmental impacts of irrigated sugarcane production: Herbicide run-off dynamics from farms and associated drainage systems Agriculture, Ecosystems and Environment 180, 123 135

De Blas, A., Garrido, A., Willaarts, B. (2016) Evaluating the Water Footprint of the Mediterranean and American Diets Water 8(10):448

De Fraiture, C., D., Wilchens, D. (2010) Small private irrigation: Enhancing benefits and managing trade-offs Agricultural Water Management 131, 1,175-182

De Fraiture, C., Molden, D., Wilchens, D. (2010) Investing in water for food, ecosystems, and livelihoods: An overview of the comprehensive assessment of water management in agriculture Agricultural Water Management, 97, 4, 495-501

De Stefano, L. Martínez-Cortina, L. Chico, D. (2012) An Overview of Groundwater resources in Spain. In Water, Agriculture and the Environment in Spain: can we square the circle? Editors : Lucia de Stefano, Ramón M;. Llamas. Ed.Fundación Botín Tailor and Francis CRC Press. ISBN-10: 0415631521.

Deasy, C., Titman, A., Quinton, J.N., (2014) Measurement of flood peak effects as a result of soil and land management, with focus on experimental issues and $38 \mathrm{G}$. Salmoral et al. / Land Use Policy 61 (2017) 24-39 scale. J. Environ. Manage. 132, 304-312, dx.doi.org/10.1016/j.jenvman. 2013.11.027

DHG (2009) Informe de sequía 22/Agosto 2009 Demarcación Hidrográfica del Guadalquivir [online, Accessed on August 2012] Available at: www.chguadalquivir.es/opencms/portalchg/laDemarcacion/guadalquivir/laGestionAgua/ informacionHidrologica/politicaGestionSequias/informeSequias/index.html

DHG (2012) Demarcación Hidrográfica del Guadalquivir. Propuesta de Plan Hidrológico de Demarcación. [online, Accessed on August 2012] Available at: www.chguadalquivir.es/opencms/portalchg/planHidrologicoDemarcacion/participacionP ublica/consultaPublica/

Dumont, A., Salmoral, G. and Llamas, M.R. (2013) The water footprint of a river basin with a special focus on groundwater: The case of Guadalquivir basin (Spain), Water Resources and Industry, 1-2: 60-76

EC (2002). Implementation of Council Directive 91/676/EEC concerning the protection of waters against pollution caused by nitrates from agricultural sources. Luxembourg: Office for Official Publications of the European Communities.

EC (2012) Working Draft Best Available Techniques (BAT)Reference Document for the Production of Pulp, Paper and Board Joint Research Center [online, Accessed on August 2012] Available at: eippcb.jrc.es/reference/ 
Environment secretary of São Paulo state (2002), Lei Estadual No 11.241, De 19 de Setembro de 2002. Accessed September 2015. Available at: www.al.sp.gov.br/norma/?id=217 Additional information available at: www.ambiente.sp.gov.br/etanolverde/

EPA 2007. EISA, Energy Independence and Security Act. H.R. 6. [online] Accessed September 2013 www.gpo.gov/fdsys/pkg/BILLS-110hr6enr/pdf/BILLS-110hr6enr.pdf

Ercin, A.E., Aldaya, M.M. and Hoekstra, A.Y. (2011) Corporate water footprint accounting and impact assessment: The case of the water footprint of a sugar-containing carbonated beverage, Water Resources Management, 25(2): 721-741

Ercin, A.E., Hoekstra, A.Y., (2014) Water footprint scenarios for 2050: a global analysis. Environ. Int. 64, 71-82

Ercin, A.E., Mekonnen, M.M., Hoekstra, A.Y., (2013) Sustainability of national consumption from a water resources perspective: the case study for France. Ecol. Econ. 88, 133-147

Estrela, T. Y L. Quintas (1996), El sistema integrado de modelización precipitación aportación SIMPA. Revista de Ingeniería Civil, no 104, páginas 43-52. CEDEX - Ministerio de Fomento, 1996

Fader, M., Gerten, D., Thammer, M., Heinke, J., Lotze-Campen, H., Lucht, W., Cramer, W., (2011) Internal and external green-blue agricultural water footprints of nations, and related water and land savings through trade. Hydrol. Earth Syst. Sci. 15 (5), 1641-1660.

Falkenmark, M., Röckstrom, J,. (2006) The new blue and green water paradign: breaking new groung for water resources planning and management. Journal of water resources planning and management, 132, 3 .

FAO (2009) CROPWAT 8.0 model, Food and Agriculture Organization, Rome, Italy. [online, Accessed on August 2012] Available at: www.fao.org/nr/water/infores_databases_cropwat.html.

FAO 2008. Bionergy, Food Security and Sustainability - Towards an International Framework. In: High-Level Conference on Word Food Security: The Challenges of Climate Change and Bioenergy. Rome, 3-5 June. 2008.

FAO 2013. Biofuels and food security: A report by the High Level Panel of Experts on Food Security and Nutrition of the Committee on World Food Security. FAO, Rome.

Farias, C.H. A., Fernandes, P., Dantas Neto, J., Gheyi H. 2008.Eficiência no usa da água na cana de açúcar sob diferentes laminas de irrigação e níveis de zinco no litoral norte paraibano. Eng. Agríc., Jaboticabal, v.28, n.3, p.494-506.

Farinacci, J. S., Ferreira, L. d. C., Batistella, M.(2013) Forest transition and ecological modernization: eucalyptus forestry beyond good and bad. Ambient. soc., 16, 2, pp. 25-46

Feng, K., K. Hubacek, S. Yim Ling, A. K. Chapagain, J. M. Yang Yu, D. Guan and J. Barrett (2011). Spatially explicit analysis of water footprints in the UK. Water 3: 43-63. 
Filoso, S., Carmo, J. B., Mardegan, S.F., Lins, S.R.M., Gomes, T.F., Martinelli, L.Z. (2015) Reassessing the environmental impacts of sugarcane ethanol production in Brazil to help meet sustainability goals. Renewable and Sustainable Energy Reviews 52

Foley, J. A., Ramankutty, N., Brauman, K. A., Cassidy, E. S., Gerber, J. S. Johnston, M. Mueller, N. D. O/'Connell, C. Ray, D. K. West, P. C. Balzer, C. Bennett, E. M. Carpenter, S. R. Hill, J. Monfreda, C. Polasky, S. Rockstrom, J. Sheehan, J. Siebert, S. Tilman, D. Zaks, D. P. M. (2011) Solutions for a cultivated planet Nature 478,337-342

Foster, S.S.D., Perry, C.J. (2009) Improving groundwater resource accounting in irrigated areas: a prerequisite for promoting sustainable use. Hydrogeology Journal (2010) 18: 291-294

Francke, I.C.M., Castro, J.F.W. 2013. Carbon and water footprint analysis of a soap bar produced in Brazil by Natura Cosmetics. Water Resources and Industry, v. 1-2, p. 37-48.

Fulton, J., Cooley, H., Gleick, P. H. (2014) - Water Footprint Outcomes and Policy Relevance Change with Scale Considered: Evidence from California Water Resources Management, 28, Issue 11,3637-3649

Furtado, A. T., Scandiffio, M. I. G., Cortez, L. A. B. (2011) The Brazilian sugarcane innovation system. Energy Policy 39 p. 156-166.

Galli, A., Wiedmann, T., Ercin, E., Knoblauch, D., Ewing, B. and Giljum, S. (2012) Integrating ecological, carbon and water footprint into a "footprint family" of indicators: Definition and role in tracking human pressure on the planet, Ecological Indicators, 16: 100112

García-Morillo, J., Rodríguez Díaz, J.A., Camacho E., Montesinos, P., (2014) Linking water footprint accounting with irrigation management in high value crops Journal of Cleaner Production 87, 594-602

García-Vila, M., I.J. Lorite, M.a. Soriano, and E. Fereres. (2008) "Management Trends and Responses to Water Scarcity in an Irrigation Scheme of Southern Spain.” Agricultural Water Management 95 (4): 458-468.

Garnett, T., Appleby, C. Balmford, A. Bateman, I. J. Benton, T. G., Bloomer, P. , Burlingame, B. Dawkins, M. Dolan, L. Fraser, D. , Herrero, M. Hoffmann, I. Smith, P., Thomton, P. K., Toulmin, C. Vermeulen, S. J. Godfray H. C. J. (2013) Sustainable Intensification in Agriculture: Premises and Policies Science. Vol. 341, Issue 6141, pp. 33-34

Garrido, A., M.R. Llamas, C. Varela, P. Novo, R. Rodríguez Casado y M.M. Aldaya (2010) Water footprint and virtual water trade in Spain: policy implications. Observatorio del Agua. Fundación Marcelino Botín. Santander. 2008.

Gerbens-Leenes. W., Hoekstra, A.Y. 2012. The water footprint of sweeteners and bioethanol. Environment International, n. 40, p. 202-211.

Gerbens-Leenes. W., Hoekstra, A.Y., van der Meer. T.H. 2009. The water footprint of bioenergy. PNAS, v. 106, n. 25, p. $10219-10223$. 
Gerben-Leenes, P. W., Mekonnen, M.M. and Hoekstra, A.Y. (2013) Water Resources and Industry 1-2, 25-36

Ghiberto, P.J. Libardi, P.L. Brito, A.S. Trivelin P.C.O. 2009. Leaching of nutrients from a sugarcane crop growing on an Ultisol in Brazil, Agricultural Water Management 96, 1443-1448.

Ghiberto, P.J., Libardi, P.L., Brito, A.S., Trivelin, P.C.O., 2011. Nitrogen fertilizer leaching in an Oxisol cultivated with sugarcane. Scientia Agricola 68, 86-93

Giambelluca, T.W.., Scholz, F.G., Bucci, S.J., Meinzer, F.C. (2009) Evapotranspiration and energy balance of Brazilian savannas with contrasting tree density Agricultural and Forest Meteorology 149 1365-1376

Giannoccaro, G., and J. Berbel. (2011) "Influence of the Common Agricultural Policy on the Farmer's Intended Decision on Water Use.” Spanish Journal of Agricultural Research 9 (4) (December 1): 1021-1034.

Giordano, M.; Turral, H.; Scheierling, S. M.; Tréguer, D. O.; McCornick, P. G. (2017). Beyond "More Crop per Drop": evolving thinking on agricultural water productivity. Colombo, Sri Lanka: International Water Management Institute (IWMI); Washington, DC, USA: The World Bank. 53p. (IWMI Research Report 169). doi: 10.5337/2017.202.

Goldemberg, J., Coelho S. T., Guardabassi P. (2008) The sustainability of ethanol production from sugarcane. Energy Policy 36 2086- 2097

Gordon, L., J., Finlayson, M., Falkenmark, M., (2010) Managing water in agriculture for food production and other ecosystem services Agricultural Water Management 97, 512-519

Granado, R., San Miguel, P., García, R., Polonio, D., (2008) Impact of the reforms of the cotton support scheme in Andalusia. Proceedings of International Cotton Conference on "Rationales and Evolution of Cotton Policies" Page No. 38-49 . May 13-17, 2008. Montpellier (France).

Gunkel, G. Kosmol, J. Sobral, M. Rohn, H. Montenegro, S. Aureliano, J. 2007. Sugar Cane Industry as a Source of Water Pollution - Case Study on the Situation in Ipojuca River, Pernambuco, Brazil. Water Air Soil Pollut (2007) 180:261-269

Guzmán, C.D., Verzijl, A., Zwarteveen, M. (2017) Water footprints and 'pozas': Conversations about practices and knowledges of water efficiency. Water,9, 16

Hardy, L., Garrido, A., Juana, L. (2012) Evaluation of Spain's Water-Energy Nexus International Journal of Water Resources Development 28(1):151-170.

Herath, I., Green, S., Horne, H., Singh, R., Mclaren, S., Clothier, B. (2013b). Water footprinting of agricultural products: evaluation of different protocols using a case study of New Zealand wine. Journal of Cleaner Production, v. 44, p. 159-167.

Hess, T. (2010) Estimating Green Water Footprints in a Temperate Environment. Water $2010,2,351-362$

Hoekstra, A.Y., Hung, P.Q. (2002). Virtual water trade: A quantification of virtual water flows between nations in relation to international crop trade, $V$ alue of $W$ ater Research Report Series No.11, UNESCO-IHE. 
Hoekstra. A.Y, Chapagain, A.K. (2007) Water footprints of nations: Water use by people as afunction of their consumption pattern. Water Resour Manage, n. 21, p. 35-48.

Hoekstra, A.Y., Chapagain, A.K., Aldaya, M.M. and Mekonnen, M.M. (2011) The water footprint assessment manual: Setting the global standard, Earthscan, London, UK.

Hoekstra, A.Y., Mekonnen, M.M., Chapagain, A.K., Mathews, R.E. and Richter, B.D. (2012) Global monthly water scarcity: Blue water footprints versus blue water availability, PLoS ONE 7(2): e32688

Hoekstra, A.Y. and Mekonnen, M.M. (2012) The water footprint of humanity, Proceedings of the National Academy of Sciences, 109(9): 3232-3237.

Hoekstra, A.Y. (2014) Sustainable, efficient and equitable water use: The three pillars under wise freshwater allocation, WIREs Water, 1(1): 31-40

Hoekstra, A.Y. and Wiedmann, T.O. (2014) Humanity's unsustainable environmental footprint, Science, 344(6188): 1114-1117

Hoekstra. A.Y, Chapagain, A.K. Aldaya, M.M. Mekonnen, M.M. (2011). The Water Footprint Assessment Manual. Setting the Global Standard. Londres. Washington. Earthscan.

Hoekstra. A.Y. (2017) Water Footprint Assessment: Evolvement of a New Research Field Water Resour Manage 31:3061 - 3081.

Hoff, H., Falkenmark, M., Gerten, D., , Gordon, L., Karlberg, L. Rockström, J. (2009) Greening the global water system Journal of Hydrology 384, 3-4 177-186

Huang, K., Z. Wang, Y. Yu and S. Yang (2015). Assessing the environmental impact of the water footprint in Beijing, China Water Policy.

Hughes, S., Partzsch, L., Gaskell, J. 2007. The development of biofuels within the context of the global water crisis. Sustainable Development Law \& Policy, v. 7, n. 22, p. 58-62.

Hurtado, María Dolores, Luis Andreu, José María Abril, and Antonio Delgado. 2011. "Nitrate Loss from a Tile-drained Reclaimed Marsh Soil from SW Spain Amended with Different Products." Nutrient Cycling in Agroecosystems 91 (3) (September 17): 255-267.

IBGE - Brazilian Institute of Statistics (2016) censo agropecuario. [online] available at: www.ibge.gov.br/home/estatistica/economia/pam/2013/default.shtm

IBGE - Brazilian Institute of Statistics (2017) Municipal production statistics. [online] available at: https://sidra.ibge.gov.br/pesquisa/pam/tabelas

JA(2005) Diagnóstico del sector algodonero andaluz. Consejería de Agricultura y Pesca. Publicaciones de la Junta de Andalucía. [online, Accessed on August 2012] Available at: www.juntadeandalucia.es/servicios/publicaciones/detalle/43139.html

JA (2007) Impacto de la aplicación del régimen vigente de ayudas en el sector productor y desmotador del algodón. Consejería de Agricultura y Pesca. Publicaciones de la Junta de Andalucía. [online, Accessed on August 2012] Available at: www.juntadeandalucia.es/agriculturaypesca/portal/servicios/estadisticas/estudios-e- 
informes/agricultura/herbaceos-extensivos/sector-algodonero/impacto-de-la-reforma-delregimen-al-sector-productor-y-desmotador-del-algodon.html

Jacomine, P.K.T. 2001. Evolução do conhecimento sobre solos coesos do Brasil. In: Cintra, F.L.D., Anjos, J.L., Ivo, W.M.P. Workshop Coesão em Solos dos Tabuleiros Costeiros. Aracaju, p. 21-35.

JägermeyrJ., Gerten D., Heinke, J., Schaphoff, S., Kummu, M., Lucht, W. (2016) Water savings potentials of irrigation systems: global simulation of processes and linkages Hydrol. Earth Syst. Sci., 19, 3073-3091

Jeswani, H.,K., Azapagic, A., (2011) Water footprint: methodologies and a case study for assessing the impacts of water use Journal of Cleaner Production 19, 1288e1299

Jefferies, D., Muñoz, I., Hodges, J., King, V.J., Aldaya, M., Ercin, A.E., Milà i Canals, L. and Hoekstra, A.Y. (2012) Water Footprint and Life Cycle Assessment as approaches to assess potential impacts of products on water consumption: Key learning points from pilot studies on tea and margarine, Journal of Cleaner Production, 33: 155-166

Jewitt, Graham. (2006) "Integrating Blue and Green Water Flows for Water Resources Management and Planning." Physics and Chemistry of the Earth, Parts A/B/C 31 (15-16) (January): 753-762.

Koehler, A. (2008) "Water Use in LCA: Managing the Planet's Freshwater Resources." The International Journal of Life Cycle Assessment 13 (6) (August 28): 451-455.

Lambooy, T. (2011). Corporate social responsibility: sustainable water use. Journal of Cleaner Production, 19(8), 852-866.

Lapola, D. M., Martinelli, L. A., Peres, C. A., Ometto, J. P., Ferreira, M. E., Nobre, C. A., Aguiar, A. P. D., Bustamante, M. M. C., Cardoso, M. C., Costa, M. H., Joly, C. A., Leite, C. C., Moutinho, P., Sampaio, G., Strassburg, B. B. N., Vieira, I. C. G. (2011) Pervasive transition of the Brazilian land-use system. Nature Climate Change, 4 .

Lathuillière, M. J., Johnson, M. S., Galford, G. L., Couto, E. G. (2014) Environmental footprints show China and Europe's evolving resource appropriation for soybean production in Mato Grosso, Brazil, Environ. Res. Lett., 9, 074001,

Lathuillière, M. J., Coe, M. T., Johnson, M. S. (2016) A review of green- and blue-water resources and their trade-offs for future agricultural production in the Amazon Basin: what could irrigated agriculture mean for Amazonia? Hydrol. Earth Syst. Sci., 20, 2179-2194

Leme, E.J.A., Silva,V.C., Henrique, J.L.P., Micklos, J.E. O uso do pivot auto-propelido na aplicação de vinhaça por aspersão: viabilidade técnico-econômica. Piracicaba, IAA, Planalsucar, 1987, 65p.

Lira P. K., Tambosi L. R., Ewers, R. M., Metzge J. P. (2012) Land-use and land-cover change in Atlantic Forest. Forest Ecology and Management 278 80-89

Liu, C., Kroeze, C., Hoekstra, A.Y. and Gerbens-Leenes, W. (2012) Past and future trends in grey water footprints of anthropogenic nitrogen and phosphorus inputs to major world rivers, Ecological Indicators, 18: 42-49. 
Locatelli, B., Vignola, R., (2009) Managing watershed services of tropical forests and plantations: can meta-analysis help? Forest ecology and management. 258, 1864-1870

Lopez-Gunn, E., Zorrilla, P., Prieto, F., Llamas, M.R. (2012) Lost in translation? Water efficiency in Spanish agriculture Agricultural Water Management 108, 83-95

López Bellido, L., (2003) Cultivos industriales. Ed. Mundi-Prensa, Madrid.

Lopez-Gunn, E, Willaarts, B., Rica, M., Corominas, J., Llamas, M.R. (2013) The Spanish water "pressure cooker": Threading the interplay between resource resilient water governance outcomes by strengthening the robustness of water governance processes International Journal of Water Governance 1 13-40

Lorite, I. J., Margarita García-Vila, María-Ascensión Carmona, Cristina Santos, and MaríaAuxiliadora Soriano. (2012) "Assessment of the Irrigation Advisory Services' Recommendations and Farmers' Irrigation Management: A Case Study in Southern Spain." Water Resources Management 26 (8) (March 31): 2397-2419.

Lovarelli, D., Bacenetti, J., Fiala, M., (2016) Water footprint of crop productions. Science of the Total Environment 548 -549, 236-251

MAGRAMA (2009) Nitrogen balance of the Spanish agriculture. Spanish Ministry of the Environment and Rural and Marine Affairs. [online, Accessed on August 2012] Available at: www.ruena.csic.es/balances.html [Accessed on July 2012].

MAGRAMA (2012) Anuario de estadística agroalimentaria. Spanish Ministery for Agriculture,Food and Environment Disponible on-line: [accedido en Febrero 2011] www.mapa.es/es/estadistica/pags/anuario/introduccion.htm

Martinelli, L. A., Filoso, S. 2008. Expansion of sugarcane ethanol production in Brazil: environmental and social challenges. Ecological Applications, 18(4), p. 885-898.

Martinelli, L. M., Garrett R., Ferraz S., Naylor, R. (2011) Sugar and ethanol production as a rural development strategy in Brazil: Evidence from the state of São Paulo. Agricultural Systems 104, 419-428

Martins, R.S.L. (2014) Empresas e gestão da água: uma abordagem a partir do uso do indicador Pegada Hídrica. Tese de Doutorado. Programa de Pós Graduação em Ciência Ambiental. Universidade de São Paulo, 178 p.

Mekonnen, M.M. and Hoekstra, A.Y. (2011) The green, blue and grey water footprint of crops and derived crop products,Hydrology and Earth System Sciences, 15(5): 1577-1600

Mekonnen, M.M., Hoekstra, A.Y. and Becht, R. (2012) Mitigating the water footprint of export cut flowers from the Lake Naivasha Basin, Kenya, Water Resources Management, 26: 3725-3742.

Mekonnen, M.M. and Hoekstra, A.Y. (2014) Water footprint benchmarks for crop production: A first global assessment, Ecological Indicators, 46: 214-223.

Mekonnen, M.M., Gerbens-Leenes, P.W. and Hoekstra, A.Y. (2015a) The consumptive water footprint of electricity and heat: A global assessment, Environmental Science: Water Research \& Technology, 1(3): 285-297. 
Mekonnen, M.M., Pahlow, M., Aldaya, M.M., Zarate, E. and Hoekstra, A.Y. (2015b) Sustainability, efficiency and equitability of water consumption and pollution in Latin America and the Caribbean, Sustainability, 7(2): 2086-2112

Mekonnen, M.M. and Hoekstra, A.Y. (2015c) Global gray water footprint and water pollution levels related to anthropogenic nitrogen loads to fresh water, Environmental Science and Technology, 49(21): 12860-12868.

Mekonnen, M.M. and Hoekstra, A.Y. (2016) Four billion people facing severe water scarcity, Science Advances, 2(2): e1500323

Mello Ivo, W. M. P. ; Rossetto, R. ; Santiago, A. D. ; Barbosa, G,V.S. ; Vasconcelos, J. N . 2008. Impulsionando a Produção e a Produtividade da Cana-de-açúcar no Brasil. In: Ana Christina Sagebin Albuquerque; Aliomar Gabriel da Silva. (Org.). Desenvolvimento da Agricultura Tropical. Brasília: Embrapa, v. 1, p. 670-716.

Meloni, , A., Rudor, B. F. T., Barcellos, L., Alves, D., Rumenos, M., Adami. (2008). Prospects of the sugarcane expansion in Brazil: impacts on direct and indirect land use changes. in " Sugarcane Ethanol_Contributions to climate change mitigation and the environment" Ed. P. Zuurbier, and J. Van de Vooren. Wageningen Academic Publishers. Wageningen, The Netherlands.

Miguel-Ayala, L., van Eupen, M., Zhang, G.P., Pérez-Soba, M., Martorano, L.G. Lisboa, L. S, and Beltrao, N.E. (2016). Impact of agricultural expansion on Water Footprint in the Amazon under climate change scenarios, Science of the Total Environment, 569-570: 1159_ 1173

Milà i Canals, Llorenç, Jonathan Chenoweth, Ashok Chapagain, Stuart Orr, Assumpció Antón, and Roland Clift. 2009. "Assessing Freshwater Use Impacts in LCA: Part Iinventory Modelling and Characterisation Factors for the Main Impact Pathways." The International Journal of Life Cycle Assessment 14 (1) (September 9): 28-42.

Montesinos, P, Camacho, E, Campos, B, Rodríguez-Díaz, JA. (2011) "Analysis of Virtual Irrigation Water. Application to Water Resources Management in a Mediterranean River Basin.” Water Resources Management 25 (6) (January 13): 1635-1651.

Muller, A., Schmidhuber, J., Hoogeven, J., Steduto, P. 2008. Some insights in the effects of growing bio-energy demand on global food security and natural resources. Water Policy, n. 10 p. 83-94.

Mueller, N.D., Gerber, J. S., Johnston, M., Ray, D.,K., Ramankutty, N., Foley, N.A.,(2012) Closing yield gaps through nutrient and water management Nature 490, 254-257

Munro, S. Fraser, G.V.C. Snowball, J., Pahlow, M. (2016) Water footprint assessment of citrus production in South Africa: A case study of the Lower Sundays River Valley Journal of Cleaner Production 135 668e678

Muthu, Subramanian Senthilkannan, Y. Li, J.Y. Hu, and P.Y. Mok. (2012) "Quantification of Environmental Impact and Ecological Sustainability for Textile Fibres." Ecological Indicators 13 (1) (February): 66-74.

Neill, C., Coe, M.T., Riskin, S.H., Krusche, A.V., Elsenbeer, H., Macedo, M.N., McHorney, R., Lefebvre, P., Davidson, E.A., Scheffler, R., Figueira, A.M.e.S., Porder, S., Deegan, L.A., 
(2013) Watershed responses to Amazon soya bean cropland expansion and intensification. Philos. Trans. R. Soc. B 368 (1619), 20120425.

Novo, P., Dumont, A., Willaarts, B., Lopez-Gunn, E. (2015) More cash and jobs per illegal drop? The legal and illegal water footprint of the Western Mancha Aquifer (Spain) Environmental Science \& Policy, 51, 256-266

Oliveira, M.W. 2002 Leaching of nitrogen, potassium, calcium and magnesium in a Sandy soil cultivated with sugarcane. Pesquisa Agropecuária Brasileira, v. 6, n. 37, p. 861-868.

Page, G., Riddouth, B., Belloti, B. (2011) Fresh tomato production for the Sydney market: An evaluation of options to reduce freshwater scarcity from agricultural water use Agricultural Water Management 100,18-24

Pahlow, M., Snowball, J. and Fraser, G. (2015) Water footprint assessment to inform water management and policy making in South Africa, Water SA, 41(3): 300-313.

Palhares, J.C.P., Pezzonpane, J.,R.,M., (2015) Water footprint accounting and scarcity indicators of conventional and organic dairy production systems Journal of Cleaner Production 93 (2015) 299e307

Pellicer-Martinez, F., Martinez-Paz, J.M. (2017) The water footprint as an indicator of environmental sustainability in water use at the river basin level. Science of the Total Envionrment, $571,561-574$.

Pereira, L.S., Cordery, I., Iacovides, I., (2012) Improved indicators of water use performance and productivity for sustainable water conservation and saving. Agricultural Water Management 108, 39-51

Perry, C., Steduto, P., Allen, R.G., Burt, C.M.(2009) Increasing productivity in irrigated agriculture: Agronomic constraints and hydrological realities Agricultural Water Management, 96, 11, 1517-1524

Perry, C. (2014). Water footprints: Path to enlightenment, or false trail? Agricultural Water Management, 134, 119-125.

Pfister, Stephan, Annette Koehler, and Stefanie Hellweg. (2009) "Assessing the Environmental Impacts of Freshwater Consumption in LCA." Environmental Science \& Technology 43 (11) (June 1): 4098-104.

Pires, R.C.M. 2008. Agricultura Irrigada. Revista Tecnologia \& Inovação Agropecuária, v.1, n.1, p. $98-110$.

Power, A.G. (2010) Ecosystem services and agriculture: tradeoffs and synergies Phil. Trans. R. Soc. B 2010 365, 2959-2971

Resende, A. N. 2011. Sustentabilidade, água virtual e pegada hídrica: um estudo exploratório no setor bioenergético. 2011.81 f. Master Thesis. Sistema de Qualidade, UFRGS, Porto Alegre, RS.

Ridoutt, B. G., Pfister, S. (2010). A revised approach to water footprinting to make transparent the impacts of consumption and production on global freshwater scarcity. Global Environmental Change, 20(1), 113-120. 
Ridoutt, B. G., Pfister, S. (2012). A new water footprint calculation method integrating consumptive and degradative water use into a single stand-alone weighted indicator. The International Journal of Life Cycle Assessment. 18,1,pp 204-207

Ridoutt, Bradley G., and Stephan Pfister. (2012) “A New Water Footprint Calculation Method Integrating Consumptive and Degradative Water Use into a Single Stand-alone Weighted Indicator." The International Journal of Life Cycle Assessment (June 23).

Ridoutt, Bradley G., Peerasak Sanguansri, Michelle Nolan, and Nicki Marks. (2011) "Meat Consumption and Water Scarcity: Beware of Generalizations." Journal of Cleaner Production (October): 1-7.

Rijsberman, F R. (2006) “Water Scarcity: Fact or Fiction.” Agric. Water Manage. 80: 5-22.

Röckstrom, J., Steffen, W. ,Noone, K. ,Persson, A. ,Chapin, F. S. , Lambin, E. F.Lenton, T. M.,Scheffer, M. Folke, C. ,SchellnhuberH.J. ,Nykvist, B. ,de Wit, C. A.,Hughes, T. ,van der Leeuw, S.,Rodhe, H. ,Sorlin, S. Snyder, P. K., Costanza, R., Svedin, U, Falkenmark, M., Karlberg, L. Corell, R. W.,Fabry, V. J.,Hansen, J. ,Walker, B., Liverman, D., Richardson, K. Crutzen, P. Foley, J.A. (2009) A safe operating space for humanity Nature, 46, pp. 472-475.

Rogers, P., de Silva, R., Bhatia, R. (2002) Water is an economic good: How to use prices to promote equity, efficiency, and sustainability Water Policy, 4, 1, 1-17

Rolim, G.S., Sentelhas, P.C.; Barbieri, V. (1998) Planilhas no ambiente EXCEL para os cálculos de balanços hídricos: normal, sequencial, de cultura e de produtividade real e potencial. Revista Brasileira de Agrometeorologia, v.6, p.133-137.

Roth, D., Warner, J. (2008)Virtual water: Virtuous impact? The unsteady state of virtual water Agriculture and Human Values, 25:257-270

Rudorff, B. F. T., de Aguiar, D. A., da Silva, W. F., Sugawara, L. M., Adami, M., Moreira, M. X., (2010) Studies on the Rapid Expansion of Sugarcane for Ethanol Production in São Paulo State (Brazil) Using Landsat Data. Remote Sensing2, 4, 1057-1076, ISSN 2072-4292

SAC (2012) Sustainable Apparel Coalition [online, Accessed on August 2012] Available at: www.apparelcoalition.org/

SAIH (2012) Sistema integrado de información hidrológica. Junta de Andalucía, Agencia Andaluza del Agua. [online, Accessed on August 2012] Available at: www.juntadeandalucia.es/agenciadelagua/saih/DatosHistoricos.aspx

Salemi, L. F., Groppo J. D., Trevisan, r., de Moraes, J. M., Ferraz, S. F., Villani, J. P., DuarteNeto, P. J., Martinelli, L. A. (2013) Land-use change in the Atlantic rainforest region: Consequences for thehydrologyofsmallcatchments. Journal of Hydrology, 499, 100-109

Salmoral, G.; Dumont, A.; Aldaya, M.and Llamas, M.R. (2011a). La Huella Hídrica de la Cuenca del Guadalquivir Papeles de Agua Virtual. Número 11. Fundación Botín.

Salmoral, G., M. M. Aldaya, D. Chico, a. Garrido, and R. Llamas. (2011)b. "The Water Footprint of Olives and Olive Oil in Spain." Spanish Journal of Agricultural Research 9 (4) (December 1). 
Salmoral. G., Willaarts, B., Garrido, A., Güse, B., (2016) Fostering integrated land and water management approaches: Evaluating the water footprint of a Mediterranean basin under different agricultural land use scenarios Land Use Policy 61, 24-39

Santos, Cristina, I. J. Lorite, M. Tasumi, R. G. Allen, and E. Fereres. 2010. "Performance Assessment of an Irrigation Scheme Using Indicators Determined with Remote Sensing Techniques.” Irrigation Science 28 (6) (February 4): 461-477.

Schornagel, J, Niele, F, Worrell, E, Böggemann, M. (2012) "Water Accounting for (agro)industrial Operations and Its Application to Energy Pathways." Resources, Conservation and Recycling 61 (April): 1-15.

Schyns, J.F., Booij, M.J., Hoekstra, A.Y. (2017) The water footprint of wood for lumber, pulp, paper, fuel and firewood. Advances in water resources, 000, 1-12

Schyns, J.F., Hoekstra, A.Y. and Booij, M.J. (2015) Review and classification of indicators of green water availability and scarcity, Hydrology and Earth System Sciences, 19(11), 45814608

Sentelhas, P.C., Pereira, A.R., Marin, F.R., Angelocci, L.R., Alfonsi, R.R., Caramori, P.H., Swart, S. BH-BRASIL - balanços hídricos climatológicos de 500 localidades brasileiras. Piracicaba: ESALQ/USP, 1999.

Seuring, S., Gold, S. (2013). Sustainability management beyond corporate boundaries: from stakeholders to performance. Journal of Cleaner Production, 56, 1-6.

Seuring, S., Müller,M. (2008) From a literature review to a conceptual framework for sustainable supply chain management. Journal of Cleaner Production 16 1699-1710

Shen, L., Patel, M. K. (2010) Life cycle assessment of of man-made cellulose fibres. Lenziger Berichte 88, Ed. Lenzing AG. Disponible online [accedido Diciembre 2011] www.lenzing.com/konzern/press/publikationen/lenzinger-berichte/ausgabe-882010.html

SIAR (2012) Servicio Integral de Asesoramiento al Regante. Consejería de Agricultura y Pesca. Junta de Andalucía. [online, Accessed on August 2012] Available at: www.juntadeandalucia.es/agriculturaypesca/ifapa/ria/servlet/FrontController

Silva, M.A.S., Griebeler, N., Borges, L.C. (2007) Uso de vinhaça e impactos nas propiedades do solo e lençol freático. Revista Brasileira de Engenharia Agrícola e Ambiental. v. 11, n. 1, p. 108 114.

SINDACUCAR-AL (2012)Sindicato da industria do açúcar e do álcool no estado de Alagoas. [online] Accessed September 2013. Available at: www.sindacucar-AL.com.br.

Sojamo, (2015) Unlocking the "Prisoner's Dilemma" of Corporate Water Stewardship in South Africa-Exploring Corporate Power and Legitimacy of Engagement in Water Management and Governance Sustainability 2015, 7, 6893-6918;

Sparovek G., SchnugE., (2001) Temporal erosion-induced soil degradation and yield loss. Soil Science Society of America Joumal; 65:1479.

Sparovek, G., Berndes, G., Egeskog, A.; de Freitas, F. L. M., Gustafsson, S., Hansson, J.. (2007) Sugarcane ethanol production in Brazil: an expansion model sensitive to 
socioeconomic and environmental concerns. Biofuels, Bioproducts and Biorefining v. 1 (4) p. 270282

Steffen, W.; Richardson, K.; Rockström, J.; Cornell, S.E.; Fetzer, I.; Bennett, E.M.; Biggs, R.; Carpenter, S.R.; de Vries, W.; de Wit, C.A.; et al. (2015) Planetary boundaries: Guiding human development on a changing planet. Science, 347, 736.

Styles, D., Schoenberger,H., Galvez-Martos, J.(2012) Environmental improvement of product supply chains: Proposed best practice techniques, quantitative indicators and benchmarks of excellence for retailers Journal of Environmental Management 110 135e150

Sun, Y., L. Shen and C. Lu (2016). Study on water footprint and external water dependency of Beijing. Water Science and Technology: Water Supply, 16(4), 1077.

Tadeu, N. D. (2014) Assessment of water impacts of eucalyptus monoculture in the portion of the Basin of the Paraíba do Sul River in São Paulo (Brasil). Master's Thesis. Graduate Program of Environmental Science, Universidade de São Paulo, São Paulo, 2014

Tallis, H.T., Ricketts, T., Guerry, A.D.,Wood, S.A., Sharp, R., Nelson, E., Ennaanay, D.,Wolny, S., Olwero, N., Vigerstol, K., Pennington, D., Mendoza, G., Aukema, J., Foster, J., Forrest, J., Cameron, D., Arkema, K., Lonsdorf, E., Kennedy, C., Verutes, G., Kim, C.K., Guannel, G., Papenfus, M., Toft, J., Marsik, M., Be rnhardt, J., and Griffin, R., Glowinski, K., Chaumont, N., Perelman, A., Lacayo, M. (2013) InVEST 2.5.6 User's Guide. The Natural Capital Project, Stanford

Teixeira, E.C., Senhorelo, A.P. (2000) Avaliação de correlação entre turbidez e concentração de sólidos suspensos em bacias com uso e ocupação diferenciada.: Congresso brasileiro de engenharia sanitaria e ambiental 22., 2000, Rio de Janeiro, Anais. Rio de Janeiro: Associação Brasileira de Engenharia Sanitária e Ambiental, 2000.

UNEP (2011) "Water Footprint and Corporate Water Accounting for Resource Efficiency." Derk, Kulper, Erika Zarate, Maite M Aldaya, Morrison Jason, Schulte Peter, and Schenck Rita. Publications from sustainable consumption and production branch. [online, Accessed on August 2012] Available at: www.unep.fr/scp/publications/details.asp?id=DTI/1411/PA

ÚNICA, Uniao da agroindústria canaviera do estado de São Paulo. (2013) [online] Accessed September 2013.Available at: www.unica.com.br

UN - United Nations (2017) Transforming our world. The 2030 agenda for sustainable development. Sustainabledevelopment.un.org A/RES/70/1 Online. [available at: sustainabledevelopment.un.org/content/documents $/ 21252030 \% 20$ Agenda $\% 20$ for $\% 20$ Sus tainable $\% 20$ Development $\% 20$ web.pdf

Van Halsema, G.E., Vincent, L. (2012) Efficiency and productivity terms for water management: A matter of contextual relativism versus general absolutism Agricultural Water Management 108 9-15

Van Oel, P.R., Hoekstra, A. Y. (2012) Towards quantification of the water footprint of paper: a first estimate of its consumptive component Water Resources Management, 26, pp. 733 749 
Van Oel, P.R., Mekonnen M.M. and Hoekstra, A.Y. (2009) The external water footprint of the Netherlands: Geographically-explicit quantification and impact assessment, Ecological Economics 69(1): 82-92.

Vanham, D., T. Mak and B. Gawlik (2016a). Urban food consumption and associated water resources: The example of Dutch cities, Elsevier.

Vanham, D., del Pozo, S., Pekcan, A.G., Keinan-Boker, L., Trichopoulou, A., Gawlik, B.M. (2016b) Water consumption related to different diets in Mediterranean cities. Science of The Total Environment, 573, 15, 96-105

Vasconcelos, J. N, Rossetto, R., Mello Ivo, W. M. P., Santiago, A.D., Barbosa, G.V.S. 2008. Impulsionando a Produção e a Produtividade da Indústria sucroalcooleira. In: Ana Christina Sagebin Albuquerque; Aliomar Gabriel da Silva. (Org.). Desenvolvimento da Agricultura Tropical. Desenvolvimento da Agricultura Tropical. Brasília: Embrapa, v. 1, p. 717-733.

Velázquez, E. (2006). An input-output model of water consumption: Analysing intersectoral water relationships in Andalusia. Ecological Economics 56(2): 226-240.

Velthof, G L, Oudendag, DA and Oenema, O. (2007) "Development and Application of the Integrated Nitrogen Model.” Alterra report 1663.1 Alterra, Wageningen

Wichelns, D. (2011). Assessing Water Footprints Will Not Be Helpful in Improving Water Management or Ensuring Food Security. International Journal of Water Resources Development, 27(3), 607-619. doi:10.1080/07900627.2011.597833

Wichelns, D. (2014). Do Estimates of Water Productivity Enhance Understanding of FarmLevel Water Management? Water, 6(4), 778-795. doi:10.3390/w6040778

Willaarts, B.A; Volk, M; Aguilera, P. (2012). Assessing the ecosystem services supplied by freshwater flows in Mediterranean Agroecosystems. Agricultural Water Management 105:21 31

Zhang, Z.Y. , Yang, H. Shi M.J. (2011) Analyses of water footprint of Beijing in an interregional input-output framework. Ecol. Econ., 70 (2011), pp. 2494-2502

Zhao, X., B. Chen and Z. F. Yang (2009). National water footprint in an input-output framework - A case study of China 2002 Ecological Modelling 220(2): 245-253.

Zhuo, L., Mekonnen, M.M. and Hoekstra, A.Y. (2016a) Benchmark levels for the consumptive water footprint of crop production for different environmental conditions: A case study for winter wheat in China, Hydrology and Earth System Sciences, 20: 4547-4559.

Zhuo, L., Mekonnen, M.M., Hoekstra, A.Y. and Wada, Y. (2016b) Inter- and intra-annual variation of water footprint of crops and blue water scarcity in the Yellow River Basin (19612009), Advances in Water Resources, 87: 21-41. 